\title{
Global humanitarianism and media culture
}

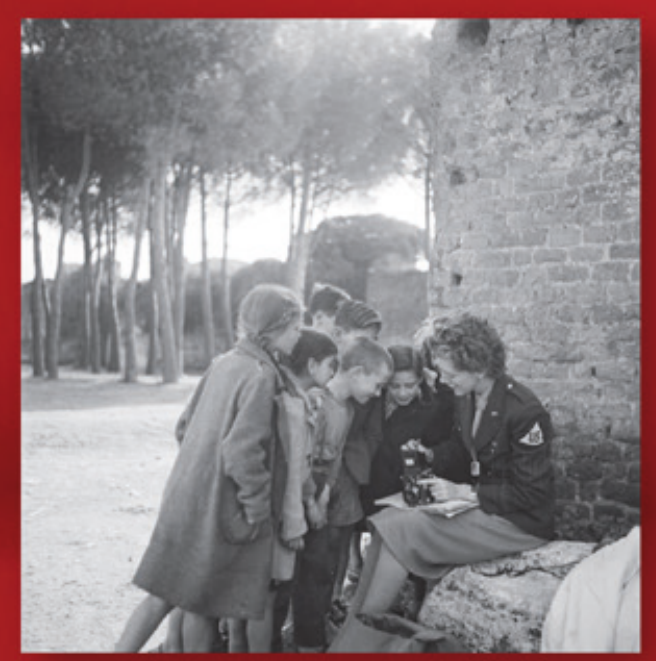

Edited by

Michael Lawrence

Rachel Tavernor 
Global humanitarianism and media culture

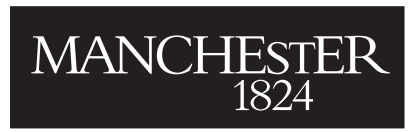

Manchester University Press 


\section{HUMANITARIANISM}

SERIES EDITOR: BERTRAND TAITHE

Th s series off rs a new interdisciplinary refl ction on one of the most important and yet understudied areas in history, politics and cultural practices: humanitarian aid and its responses to crises and conflicts. The series seeks to defineafresh the boundaries and methodologies applied to the studyof humanitarian relief and so-called 'humanitarian events'. The series includes monographs and carefully selected thematic edited collections which will cross disciplinary boundaries and bring fresh perspectives to the historical, political and cultural understanding of the ntionale and impact of humanitarian relief work.

Islamic charities and Islamic humanism in troubled times

Jonathan Benthall

Humanitarian aid, genocide and mass killings: Médecins Sans Frontières, the Rwandan

experience, $1982-97$

Jean-Hervé Bradol and Marc Le Pape

Calculating compassion: Humanity and relief in war, Britain 1870-1914

Rebecca Gill

Humanitarian intervention in the long nineteenth century

Alexis Heraclides and Ada Dialla

The military-humanitarian complex in Afghanistan

Eric James and Tim Jacoby

Donors, technical assistance and public administration in Kosovo

Mary Venner

The NGO CARE and food aid from America 1945-80: 'Showered with kindness?'

Heike Wieters 


\section{Global humanitarianism and media culture}

Edited by Michael Lawrence and Rachel Tavernor

Manchester University Press 
While copyright in the volume as a whole is vested in Manchester University Press, copyright in individual chapters belongs to their respective authors.

This electronic version has been made freely available under a Creative Commons (CC-BY-NC-ND) licence, thanks to the support of Knowledge Unlatched, which permits non-commercial use, distribution and reproduction provided the author(s) and Manchester University Press are fully cited and no modifications or adaptations are made. Details of the licence can be viewed at https://creativecommons.org/licenses/by-nc-nd/3.0/

Published by Manchester University Press

Altrincham Street, Manchester M17JA

www.manchesteruniversitypress.co.uk

British Library Cataloguing-in-Publication Data

A catalogue record for this book is available from the British Library

ISBN 9781526117298 hardback

ISBN 9781526117304 open access

First published 2019

The publisher has no responsibility for the persistence or accuracy of URLs for any external or thirdparty internet websites referred to in this book, and does not guarantee that any content on such websites is, or will remain, accurate or appropriate.

Typeset by Out of House Publishing 


\section{Contents}

List of figures

page vii

List of contributors

Acknowledgements

Introduction: Global humanitarianism and media culture

Michael Lawrence and Rachel Tavernor

Part I: Histories of humanity

1 'United Nations children' in Hollywood cinema: Juvenile actors and humanitarian sentiment in the $\$ 40 \mathrm{~s}$

Michael Lawrence

2 Classical antiquity as humanitarian narrative: The Marshall Plan films about Greece

Katerina Loukopoulou

3 'The mot potent public relations tool ever devised'?

The nited States Peace Corps in the arly 960s

Agnieszka Sobocinska

Part II: Narratives of humanitarianism

4 The aive republic of aid Grassroots exceptionalism in humanitarian memoir

Emily Bauman

5 'Telegenically dead Palestinians': Cinema, news media and perception management of the Gaza conflicts

Shohini Chaudhuri 
6 The Unknown Famine: Television and the pditics of British humanitarianism

Andrew Jones

Part III: Reporting refuge and risk

7 European borderscapes: The management of mgration between care and control

Pierluigi Musarò

8 The ole of aid gencies in the melia portrayal of chldren in Za'atari refugee camp

Toby Fricker

9 Selling the lottery to earn salvation: Journalism practice, risk and humanitarian communication

Jairo Lugo-Ocando and Gabriel Andrade

\section{Part IV: Capitalism, consumption and charity}

10 Consumption, glbal humanitarianism and childhood

Laura Suski

11 Liking visuals and visually liking on Facebook: From starving children to satirical saviours

Rachel Tavernor

12 The orporate karma carnival: Offline and online games, branding and humanitarianism at the Roskilde Festival

Lene Bull Christiansen and Mette Fog Olwig

Index 


\section{Figures}

11 The Amazing Mrs Holliday (Jean Renoir/Bruce Danning, 1943). page 26

1.2 The Amazing Mrs Holliday (Jean Renoir/Bruce Danning, 1943). 26

13 Heavenly Days (Howard Estabrook, 1944). 28

14 Heavenly Days (Howard Estabrook, 1944). 29

1.5 The Boy with Green Hair (Joseph Losey, 1948). 30

1.6 The Boy with Green Hair (Joseph Losey, 1948). 31

2.1 The Good Life (Humphrey Jennings, 1951).

2.2 The Good Life (Humphrey Jennings, 1951). 51

6.1 This Week: The Unknown Famine (Thames Television, 973). 126

6.2 This Week: The Unknown Famine (Thames Television, 973). 127

8.1 Malala Yousafzai at the camp, photographed by Toby Fricker. 174

12.1 Collection of uine from the fetival which Danish farmers will 'turn into beer', photographed by Mette Fog Olwig, 2015.

12.2 Sensational Football tournament at the Roskilde Festival, photographed by Mette Fog Olwig, 2013.

12.3 Participants in the Ensational Football tournament, photographed by Mette Fog Olwig, 2013.

12.4 Spectators and participants in the Sensational Football tournament, photographed by Mette Fog Olwig, 2013.

12.5 Orange Karma booth where festivalgoers and asylum-eekers can meet and talk during a mil or hair treatment, photographed by Mette Fog Olwig, 2013.

12.6 Screen showing GAME/Orange Karma promotion materials during basketball game 2015, photographed by Lene Bull Christiansen, 2015.

12.7 Players warming up for the elebrity basketball game, photographed by Lene Bull Christiansen, 2015.

12.8 Photo of commercial poster advertising Hummd sneakers at Roskilde Festival, photographed by Mette Fog Olwig, 2013. 


\section{Contributors}

Gabriel Andrade received a Doctorate of Human Sciences from Universidad del Zulia, Venezuela. He is currently a Lecturer of Behavioral Sciences at Xavier University School of Medicine, Aruba. He has written peer-reviewed articles on religiousstudies, psychology and philosophy. He published El darwinismo y la religion (University of Cantabria Press, 2009), amongst other books. His research interests are in medicalethics, religion and health, and evolutionary psychology. He frequently writes op-ed pieces on ethics and arrent affai s in The Prindle Post.

Emily Bauman teaches core humanities and human rights and development at New YorkUniversity. She has published on the visual rhetoric of politicalbiography, NGO video narratives and postcolonial theory, amongst other topics. She is currently at work on a bodk on eligious iœnography and the Cold War.

Shohini Chaudhuri is a SeniorLecturer in Film at the University of Essex. She has written three books - Contemporary World Cinema: Europe, the Middle East, East Asia and South Asia (Edinburgh University Press, 2005), Feminist Film Theorists (Routledge, 2006) and Cinema of the Dark Side: Atrocity and the Ethics of Film Spectatorship (Edinbuigh University Press, 2014). Her most recent work focuses on the intersections between film and human rights, including book chapters and articles about documentaries on the Syrian and Iraq wars, and a forthcoming book on freedom of expression and the inema.

Lene Bull Christiansen is an Associate Professor at the Institute of Communication and Arts at Roskilde University, Denmark. Her current work deals with development communication and celebrity and nationalism in Denmark. She is a core member of the Nordic Celebrity Studies Network.

Toby Fricker works as part of UNICEF's global emergency response team, supporting offices in conflict settings, from Afghanistan to Syria and Nigeria to 
Ukraine. Toby was based in Jordan from 2012 to 2015, working with UNICEF in covering the response to the Syrian refugee crisis. He previouslylived in countries including Laos, Indonesia and Uganda, working in many others in between as a communications professional, videographer and journalist.

Andrew Jones is an Assistant Professor in Global Sustainable Development at the University of Warwick. His research focuses on the recent history of British humanitarianism, with a focus on the rise of NGOs. He is currently preparing a monograph which will investigate how the contemporary humanitarian sector developed in po\$-war Britain

Michael Lawrence is Reader in Film Studies at the University of Sussex. He is the author of Sabu (British Film Institute, 2014) and the co-editor, with Laura McMahon, of Animal Life and the Moving Image (British Film Institute, 2015) and, with Karen Lury, of The Zoo and Screen Media: Images of Exhibition and Encounter (Palgrave Macmillan, 2016). He is currently working on a monograph, The Children and the Nations: Juvenile Actors, Hollywood Cinema and Humanitarian Sentiment, 1940-1960.

Katerina Loukopoulou is Associate Lecturer at the London College of Communication of the University of the Arts London, where sheteaches on the MA Documentary Film. Her publications includearticles in the International Journal of Media and Cultural Politics and Film History and essays in the collections Learning With the Lights Off: Educational Film in the United States (Oxford University Press, $20 \mathrm{l2}$ ) and Cinema's Military Industrial Complex (University of California Press, 2018). Her current project, supported by a British Academy/ LeverhulmeSmall Research Grant, investigates the relationship between pacifism and doamentary cinema.

Jairo Lugo-Ocando is Associate Professor in the School of Media and Communication at the University of Leeds, UK. Before becoming an academic, he worked as a journalist, correspondent and news editor for several news media in Latin America and the United States. He has been a Visiting Fellow at the National University of Singapore and an associated professor of the doctoral programme in Communications at the University of Malaga (Spain). His research deals with the relation between journalism, development, poverty and social exclusion $\mathrm{He}$ is author of Blaming the Victim: How Global Journalism Fails Those in Poverty (Pluto Press, 2014) and author of the forthcoming Developing News: Global Journalism and Coverage of the Third World (Routledge, 2015).

Pierluigi Musarò is Associate Professor of Sociology at the University of Bologna, Italy, Visiting Fellow at the London School of Economics and Political Science (LSE), Research Fellow at the Institute for Public Knowledge at the New York 
University, and Faculty Expert/Mentor for the WISE Learners' Voice Program, Qatar Foundation, where he teaches 'humanitarian communication' and 'media and security.' His teaching and research examines humanitarian communication, media and security. He has published several articles on migration, cultural sociology and sustainable tourism.

Mette Fog Olwig, a human geographer, is Assistant Professor in International Development Studies at the Department of Society and Business at Roskilde University, Denmark. She has published on development and humanitarian communication in relation to ethical labelling, celebrity humanitarianism, benefit events and branding globally, as well as on dynamics, power relations, narratives and development policy in relation to natural disasters and climate change in Vietnam, Ghana and Tanzania. She is currently doing research on business-humanitarian partnerships and how they elate to commodfying compassion.

Agnieszka Sobocinska is Senior Lecturer in the Faculty of Arts at Monash University, and Deputy Director of the National Centre for Australian Studies. She is an historian with research interests in the intersection of popular opinion and foreign affai s through travel and tourism, and of popular Western perceptions of the third world. She is the author of Visiting the Neighbours: Australians in Asia (NewSouth,2014) and, with David Walker, co-editor of Australia's Asia: from Yellow Peril to Asian Century (UWA Publishing, 2012).

Laura Suski is Professor in the Department of Sociology at Vancouver Island University. She also teaches in the Liberal Studies Department and the Global Studies Program. She holds a PhD in social and political thought from York University. Her current research interests includethe analyses of politicalemotions, humanitarianism as an Enlightenment project, notions of the family and childhood in global ethics, and new theories of consumption and taste.

Rachel Tavernor recently completed her AHRC-funded PhD titled Communicating Solidarity: The Cultural Politics and Practices of Humanitarian NGO Campaigns at the University of Sussex. Her research interests includeanti-poverty activism, feminism and rights based approaches to communication. She is the founding editor of the interdisciplinary website, Re.framing Activism, and has worked for humanitarian NGOs in youth, community and campaign roles. 


\section{Acknowledgements}

We would like to thank all of our contributors for their enthusiasm and patience. Thank you to Tony Mason, Rob Byron, Alun Richards and Deborah Smith at Manchester University Press, and to Gail Welsh. Special thanks to our colleagues at the University of Sussex, and especially Kate Lacey, Elefth ria Lekakis, Sarah Maddox and Monika Metykova. 



\title{
Introduction: Global humanitarianism and media culture
}

\author{
Michael Lawrence and Rachel Tavernor
}

Since the 1990s, there has been a marked increase in the scholarly consideration of the relationships between humanitarianism and media culture, and from a range of critical and disciplinary perspectives and institutional contexts. ${ }^{1}$ An emergent fi ld of inquiry has been signific ntly shaped by several foundational analyses of the representation of humanitarian crisis, and particularly of the media's various repertoires for elaying to its audiences the desperate suff ring of distant others. ${ }^{2}$ As SuzanneFranks states, 'Our awareness of nearlyall humanitarian disasters is defin $\mathrm{d}$ by the media.'. Subsequently, and as Keith Tester argues, 'if we want to understand modern humanitarianism, we need also to understand modern media culture, because the two are inextricably entwined.'

An exhaustive historicaloverview of modern humanitarianism and media culture is beyond the scope of this introduction and book; however, with this collection we intend to understand someof thelonger historical, cultural and political contexts that shape how humanitarian relationships have been mediated since the Second World War. As Simon Cottle and Glenda Cooper suggest, 'media and communications ... have entered increasingly and sometimes profoundy into the contemporary fi ld of humanitarianism and this warrants sustained, critical attention. ${ }^{5}$ Drawing and building on scholarship from sociology, journalism, development studies, politics, film and media studies and anthropology, we investigate the complex relationships between humanitarianism and popular media forms, technologies, events and cultures. Our authors explore a variety of media, from film, television and memoirs to music festivals and social media, and chart the development of diff rent modes of communicating humanitarianism. As this book illustrates, the twentieth century is a signific nt period of transition in humanitarian and media institutions, which requires further analysis and investigation.

The origins of humanitarianism have recently become the subject of historiographical debate. ${ }^{6}$ Humanitarianism, as Peter Walker and Daniel G. Maxwell argue, is a system that 'evolved.' Scholars such as Jonathan Benthall and Kevin Rozario suggest that global humanitarianism acquired its distinctive contemporary ethos 
and form in the West with the founding of the International Committee of the Red Cross in 1863, and subsequently with the work of the American Red Cross during the First WorldWar. ${ }^{8}$ However, humanitarianism underwent a signific nt shift in the aftermath of the Second World War. Craig Calhoun, for example, claims the civilian suff ring and population displacement that characterised and distinguished the war led to a new idea of 'humanitarian emergency'. War was no longer the sole focus of humanitarian effo ts. Instead a concern for a commonhumanity was promoted with 'renewed effo ts to articulate humanitarian norms and build institutions to enforce them.' The institutional, organisational and operational development of humanitarianism that began accelerating in the 1940s is therefore simultaneous with dramatic shifts in media culture (for example, the growing popularity of television and of mass-market paperbacks) and thus warrants and requires an expansion and a reorientation of our'criticalattention'. Thepopuarising of the humanitarian project, intrinsically entwined with media culture, has created further tensions, as 'media logics' increasingly determine the claracter of virtual humanitarian relations.

The chapters in this collection off $r$ original interrogations of the representation of humanitarian crisis and catastrophe, and the refraction of humanitarian intervention and action, from the mid-twentieth century to the present, across a diverse range of media forms: traditional and contemporary screen media (film, television and online video) as well as newspapers, memoirs, music festivals and social media platforms (such as Facebook, YouTube and Flickr). Addressing humanitarian media culture as it evolved over a period of more than seventy years, the chapters off $\mathrm{r}$ a critical assessment of the historical precedents of our contemporary humanitarian communications. The contributors to the book are all specialists in the fi lds of media and communications, film studies, cultural studies, history or sociology: these diff rent disciplinary perspectives inform their approaches to and understanding of the relationship between humanitarianism and media culture. Our authors reveal and explore the signific nt synergies between the humanitarian enterprise, the endeavour to alleviate the suff ring of particular groups, and media representations, and their modes of addressing and appealing to specific publics. The humanitarian community has more recently (since the end of the Cold War) questioned its ambitions, purposes and principles, while also debating its relationship to politics and ethics. ${ }^{10}$ Michael Barnett nd Tho as G. Weiss suggest this period is marked by the 'struggle to (re)define the humanitarian identity', specifica ly in relation to 'the boundaries, unity, and purity of humanitarianism. ${ }^{11}$ The role played by the media in humanitarian endeavours is arguably central to such questions and struggles.

Humanitarian media is typically constituted by revelatory yet routine representations of emergency and exigency aimed at the promptsolicitation of sympathy and solidarity. As Erica Bornstein and Peter Redfi ld suggest, contemporary humanitarianism 'remains inherently presentist' due to its concern for 'the lives and welfare of those now living': 'the life-saving norm of international aid ... at its core seeks to confront immediate suff ring, usually understood as bodilyor psychological 
anguish. ${ }^{12}$ However, the 'immediate suff ring' happening now is more often than not 'distant suff ring' taking place somewhere else, to 'distant strangers. ${ }^{13}$ The suff ring must be mediated to the public (in words, in images, in sounds). In many cases, the communication of suff ring is combined with a plea to act (for instance, to make a donation to an appropriate charitable organisation). John Silk, in 'Caring at a Distance', argues that media networks 'play a signific nt part in extending the range of care and caring beyond the traditional context of shared spatio-temporal locale and our "nearest and dearest" to embrace "distant others"'. ${ }^{14}$ Th s 'embrace', however, remains virtual and imaginary. Despite the instantaneity of today's global media communications, their representations paradoxically preserve distance (and subsequently the diff rences) between those who are suff ring and those who are able to intervene. Ourbook contributes to further understanding the diff rent ways people experience such a humanitarian 'embrace'.

Cottleand Cooper acknowledge the role of communications in 'the growing recognition of distant others as notso diff rent fromourselves', and in the subsequent 'development of a humanitarian sensibility.' ${ }^{15}$ Certain diff rences nevertheless obtain. Th relationship between humanitarianism and media culture is often addressed in relation to strategic or ideological communications, with a particular focus on the presentation of those who are suff ring to those with the potential to 'help'. Lilie Chouliaraki, for instance, has explored how the media might 'cultivate a disposition of care for and engagement with the far away other' and 'create a global public with a sense of social responsibility towards the distant suff rer.' ${ }^{16}$ Whereas Roberto Belloni is critical of the role of the media, or rather the choices it typically makes, and suggests the media 'adopt unethicaltactics to provoke an impressionamong the general public and enable humanitarian organisations to raise more funds.' ${ }^{17}$ The marketisation of humanitarianism (specificaly monetised humanitarian action) has inevitably shaped the competitive commodfic tion of both 'distant suff ring' and 'caring at a distance' by the mass media. In turn, humanitarian organisations have become 'market' players. For Ian Smillie and Larry Minear (2004) the 'humanitarian enterprise' refers to 'the global network of organisations involved in assistance and protection. Humanitarianism is the act of people helping people'; however, as the authors acknowledge, while '[an] expression of ethical concern, humanitarianism is also a business driven by market forces and by agencies seeking to maintain and expand market share. ${ }^{\prime 1}$ In a highly competitive sector, brand design and management are increasingly important for humanitarian organisations wishing to maintain visibility. ${ }^{19}$ As this collection shows, representations of humanitarianism are created in increasingly contested environments, with fi ancial, political and altural pressures shaping their poduction.

\section{Structure of book}

In Part I, 'Histories of Humanity', we begin by mapping the historical contexts of popular humanitarian communication. The authors consider how moving image 
and print media were deployed to promote awareness and understanding of, and also active involvement in, various global humanitarian endeavours, organisations and institutions that developed during and in the decades following the Second World War: the United Nations Organisation, the Marshall Plan and the US Peace Corps. Th s section examines a range of media forms, including popular cinema and television shows and documentary films, and press coverage and public relations campaigns, in order to address the ways in which humanitarianism was strategically linked to images of and ideas about childhood and internationalism, history and heritage, and altruistic intervention and 'underdevelopment'. In ' "United Nations Children" in Hollywood Cinema: Juvenile Actors and Humanitarian Sentiment in the 1940s', Michael Lawrence addresses the signific nce of the child for representations of the United Nations in studio cinema produced during and immediately following the Second World War. Lawrence suggests that Hollywood cinema of the 1940s encouraged a primarily sentimental understanding of internationalism in the era of the United Nations by off ring audiences an 'appealing' image of displaced and orphaned children from the warzones. Thechapter suggests how various genre films deployed either realism or fantasy in their ideological presentation of the war's most vulnerable victims to promote the United Nations' internationalist ethos and associated humanitarian campaigns. In chapter 2, 'Classical Antiquity as Humanitarian Narrative: The Marshall Plan Films about Greece', Katerina Loukopouloucontributes an in-depth analysis of the relationship between global humanitarianism and non fic ion cinema by examining the rhetorical representation of ancient history and national heritage in several documentary films produced to promote international relief and reconstruction endeavours in post-war Greece, audio-visual campaigns that promoted humanitarianism at a transnational level. Loukopoulouattends to the means by which Marshall Plan films sought to assert continuities between the classical and the modern periods in order to promote humanitarian campaigns to both local and transnational audiences. Focusing in particular on British director Humphrey Jennings' The Good Life (1951), she explores the signific nce of the formal relationships between foreground and background, and between image and voiceover commentary, for the film's humanitarian historiography. Agnieszka Sobocinska, in chapter 3, "'The Most Potent Public Relations Tool Ever Devised"? The United States Peace Corps in the Early 1960s', investigates how public relations and popular culture were exploited to promote the Peace Corps as a humanitarian project to the general public. Using an analysis of the United States Peace Corps' early publicity materials, Sobocinska identifi s this period as a critical historical junctue that shaped popular understandings of an altruistic America that has a moral mandate to intervene. Sobocinska considers the deliberate production of a Peace Corps mystique in which an explicit emphasis on the volunteers' patriotism, beauty and 'pioneer spirit' helped to popularise the belief in America's responsibilities towards 'underdeveloped' nations and subsequently to normalise, and gamorise, a logic of intervention. 
Part II, 'Narratives of Humanitarianism', considers the diff rent actors at work producing public understandings of humanitarianism as apolitical. The authors examine a range of media, including the memoir, the news, social media, television and film, and their representations of humanitarian relationships In chapter 4, 'The Naive Republic of Aid: Grassroots Exceptionalism in Humanitarian Memoir', Emily Bauman considers humanitarian memoir and argues that the genre can provide a counter-discourse of humanitarian government, specificaly through its presentation of the exceptional project founder or entrepreneur as the 'sovereign irrational' or even 'fool'. Bauman illustrates the signific nce of naivety in narratives presenting fi st-hand accounts of personality-driven enterprises in an increasingly institutionalised humanitarian sector. Bauman argues that popular humanitarian life-writing exploits the genre's association with confessional authenticity to off $r$ a reassuringly 'human' image of humanitarian institutions. Shohini Chaudhuri, in chapter 5, "Telegenically Dead Palestinians": Cinema, News Media and Perception Management of the Gaza Conflicts', refl cts on why such oppression is possible and acceptable. Chaudhuri explores representations of Palestinian casualties (and the disavowal of their political causes) across mainstream news coverage, social media, popular American television ( The Good Wife [2009-16]) and documentary film. The chapter concludes with an analysis of Where Should the Birds Fly (2013) by the Gazan citizen joumalist Fida Qishta, which, Chaudhuri contends, emphasises everyday violence so as to refuse the widespread tendency to separate the humanitarian crisis from political concerns. In chapter 6, 'The Unknown Famine: Television and the Politics of British Humanitarianism', Andrew Jones analyses the television coverage of the famine in Ethiopia in 1973 that was predominantly unreported in Western media. In doing so, Jones argues that there is a pressing need for sustained historical research into the relationships between media representations and politics. Jones highlights how many of the issues with the 1973 Ethiopian famine, such as NGOs' dependency upon the mass media, are pertinent today. Ths chapter considers the colonialist dimensions organising conventional humanitarian representations of emergency and suff ring in the global South, and the critical debates withinthe aid sector about the value of 'negative' images. Focusing on the influ nce of ITV's The Unknown Famine, Jones studies its dramatic impact on disaster fundraising, and specifica ly its transformation of the relationship between NGOs and both popular broadcasters and government aid pdicy and administration.

In Part III, 'Reporting Refuge and Risk', we focus on the movement of people displaced by conflicts and explore the longer histories of this current 'crisis'. Pierluigi Musarò, in chapter 7, 'European Borderscapes: The Management of Migration between Care and Control', considers both state and non-state media campaigns associated with Mediterranean border controls amidst the migration 'crisis. Focusing on Europe's border controls, and narratives of national security, Musarò's chapter critiques the dichotomies between care and control, threat and vulnerability, solidarity and indiff rence, which are presented in media campaigns and coverage. 
Musarò argues that the securitised approach to managing migration produces a depoliticised discourse of humanitarianism. The ambiguities and contradictions that characterise discourses and practices constituting the military-humanitarian governance of migration are addressed with an analysis of media representations and campaigns concerned with the loss of life as well as those targeting would-be migrants. In chapter 8, 'TheRole of Aid Agencies in the Media Portrayal of Children in Za'atari Refugee Camp', Toby Fricker charts the evolution of media coverage of young Syrian refugees in Jordan and considers refugee camps as a 'melting pot' of aid workers, journalists, visiting politicians and celebrities. Fricker explores how children were framed by the media according to established narratives that shifted in focus from the children's propensity to violence and vengeance to their urgent need for education and protection. Th s chapter argues that NGOs have an ethical duty to intervene in media narratives, and to shape the media's decision-making process during a crisis, and ultimately to amplify rather than silence the voices of children. Th section concludes with chapter 9, 'Selling the Lottery to Earn Salvation: Journalism Practice, Risk and Humanitarian Communication', in which Jairo Lugo-Ocando and Gabriel Andrade explore the tensions between joumalism and humanitarianism as social practices, and examinethe potential for representations of suff ring to address the structural problems responsible for suff ring rather than simply promote palliative measures. Theauthors argue for the strategic embrace by news joumalists of the notion of shared risk (collective, everyday uncertainty) in order to produce a political solidarity in their readers, one more likely to result in active and eff ctive responses to the problem of vulnerability. Lugo-Ocando and Andrade argue that by advancing a new humanitarian narrative, which privileges a solidarity that promotes equal relations and communicates a shared risk', a shared view of society can be created.

Part IV, 'Capitalism,ConsumptionandCharity', concludes thecollectionwith case studies that acknowledge the paradoxes that can occur when corporate actors communicate humanitarianism. Chapter 10, 'Consumption, Global Humanitarianism and Childhood, asks whether political consumerism can create a space for humanitarian care andjustice. Using an analysis of online discussions of children's toys as her central case study, Laura Suski illustrates how notions of care for 'our' children anda humanitarian impulse to protect 'other' more distant children are interwoven in consumption practices. In doing so, this chapter considers the tensions that exist when consumption practices enact notions of care, responsibility and identity. Rachel Tavernor, in chapter 11, 'Liking Visuals and Visually Liking on Facebook: From Starving Children to Satirical Saviours', explores how the architecture of Facebook, which privileges positive sentiments, changes visual representations of humanitarianism. Th s chapter draws upon an analysis of Facebook and interviews with young people, to investigate the spaces and ways in which people are invited to engage in humanitarianism. Tavernor argues that the commercial ideology of Facebook contributes to shaping and promoting humanitarian action as quick, immediate and measurable. The fi al chapter is based on original fi ldwork at a music festival in 
Denmark. In 'TheCorporate Karma Carnival: Offline and Online Games, Branding and Humanitarianism at Roskilde Festival', Lene Bull Christiansen and Mette Fog Olwig discuss the progressive and problematic aspects of popularising humanitarianism. Christiansen and Olwig illustrate the influ nce of corporate actors in producing humanitarian imaginaries that endorse their own branding strategies, and identify the hierarchies and social norms challenged during the festival. In doing so, the authors consider the complex relations that are negotiated when humanitarian causes are partnered with corporate companies.

We argue that media have become integral to humanitarianism and the changing relationships between organisations, institutions, governments, individual actors and entire sectors. Central to this book are analyses of the explicit, and implicit, power relations, and the structural global injustices, that shape the relationships created when communicating the suff ring associated with famines, disasters and wars. We edited this collection during a period reported across the media as a 'crisis'. The mass movement of people seeking refuge in the UK, and across the world, has made visible how public opinion is fractured. The humanitarian responsibilities of governments, communities and individuals continue to be debated, negotiated and redefin d. Popular discourses concerned with borders, control and hospitality, alongside a resurgence of far right nationalist rhetoric in Northern America and Western Europe, have contributed to the changing political terrain. During a period when geographicalborders and nationality are emphasised, we felt it was important to craft an international collection that crosses disciplinary borders. While the focus in this book is on distinct campaigns, festivals, films, television and reporting, we hopethat our discussions of the interweaving of humanitarianism and media culture may speak to contemporary, and future, contexts.

Research in the fi ld has often focused on representations of suff ring. Critical readings of humanitarian imagery have shown how people living in poverty are homogenouslyrepresented as 'children', are 'dehumanised', or 'imperially' imagined, and 'marketed', 'branded' and 'commodtised'. When it came to selecting an image for the front cover of this book, we were both sure about the kind of representation that we did not want to use. The photograph we chose is a self-portrait produced by Toni Frissell. In various ways it refl cts several of the themes of this collection. Frissell was a pioneering fashionphotographer in the 1930s, who, like several women photographers, subsequently became a war correspondent. Frissell volunteered her photography services to the Red Cross, the Women's Army Corps and the Eighth Army Air Force. Frissell's images were used in posters to promote the work of the Red Cross, as well as to popularise the wider humanitarian project. Theimages she produced during her assignments across Europe captured the devastation of war, particularly in her photographs of orphaned children, but also the human face of humanitarian intervention, represented by her portraits of nurses and military personnel. The original negative of our cover photograph is archived at the Library of Congress and titled as 'Toni Frissell, sitting, holding camera on her lap, with several 
children standing around her, somewhere in Europe. The photograph captures a relationshipbetween Frissell and the children, the latter expressing bothintrigue and delight as she shows them the camera with which she will mediate their suff ring to others. Frissell's photograph thus foregrounds the interaction between the producer and the subjects of humanitarian media by depicting their diff rent relationships with the technological basis of humanitarian media itself. Our book unpacks and explores the historical, cultural and political contexts that have shaped the mediation of humanitarian relationships. Together, the chapters illustrate the continuities and connections, as well as the diff rences, which have characterised the mediatisation of both states of emergency and acts of amelioration. The collection considers the ways in which media texts, technologies and practices refl ct and shape the shifting moral, political, ethical rhetorical, ideological and material dimensions of international humanitarian emergency and intervention. It is important, we argue, that the histories of humanitarian media culture inform contemporary debates.

\section{Notes}

1 See, for example, J. Benthall, Disasters, Relief and the Media (London: I. B. Tauris, 1993); R. I. Rotberg and T. G. Weiss (eds), From Massacres to Genocide: The Media, Public Policy and Humanitarian Crisis (Washington, DC: The Brookings Institute/ Cambridge, MA: The World Peace Foundation, 1996); S. Moeller, Compassion Fatigue: How the Media Sell Disease, Famine, War and Death (Londonand New York: Routledge, 1999); L. Boltanski, Distant Suffering: Morality, Media, and Politics, trans. G. Burchell (Cambridge: Cambridge University Press, 1999); K. Tester, Compassion, Morality and the Media (Buckingham and Philadelphia: Open University Press, 2001); S. Cohen, States of Denial: Knowing about Atrocities and Suffering (Cambridge: Polity Press, 2001; revised 2017); B. Höijer, 'TheDiscourse of Global Compassion: The Audience and Media Reporting of Human Suff ring', Media, Culture and Society, 26:4 (2004), pp. 513-31; L. Chouliaraki, The Spectatorship of Suffering (London, Thou and Oaks and New Delhi: SAGE, 2006); K. Tester, Humanitarianism and Modern Culture (Pennsylvania: PennState Press, 2010); S. Linfi ld, The Cruel Radiance: Photography and Political Violence (Chicago andLondon: University of Chicago Press, 2010); W. Hesford, Spectacular Rhetorics: Human Rights Visions, Recognitions, Feminisms (Durham, NC and London: Duke University Press, 2011); S. Orgad, 'Imagining Others: Representations of Natural Disasters', in Media Representation and the Global Imagination (Cambridge and Malden, MA: Polity Press, 2012), pp. 52-80; S. Franks, Reporting Disasters: Famine, Aid, Politics and the Media (London: C. Hurst \& Co., 2013); L. Chouliaraki, The Ironic Spectator: Solidarity in the Age of Post-Humanitarianism (Cambridge: Polity, 2013); P. Robinson, 'News Media and Communications Technology', in R. M. Ginty and J. H. Peterson (eds), The Routledge Companion to Humanitarian Action (Abingdon and New York: Routledge, 2015), pp. 254-66; and H. Fehrenbach and D. Rodogno (eds), Humanitarian Photography: A History (New York: Cambridge University Press, 2015). For anthologies that focus on contemporary (twenty-fi st century) humanitarian media, practices and challenges, see S. Cottle and G. Cooper (eds), Humanitarianism, Communications and Change (New York: Peter Lang, 2015) and R. Andersen and P. L. de Silva (eds), The Routledge Companion to Media and Humanitarian Action (New York: Routledge, 2017). Several collections have examined the relationships between the mass media and international development and human rights, which have become 
increasingly intertwined with humanitarianism since the end of the Second World War: see D. Lewis, D. Rodgers and M. Woolcock (eds), Popular Representations of Development: Insights from Novels, Films, Television and Social Media (London: Routledge, 2014) and T. A. Borer (ed.), Media, Mobilization, and Human Rights (London and New York: Zed Books, 2012). For explorations of the signific nce of celebrity culture across these overlapping spheres, see M. K. Goodman and C. Barnes, 'Star/Poverty Space: The Making of the "Development Celebrity", Celebrity Studies, 2:1(2011),pp. 69-85; L. Chouliaraki, 'TheTh atricality of Humanitarianism: A Critique of Celebrity Advocacy', Communication and Critical/Cultural Studies, 9:1 (2012), pp. 1-21; I. Kapoor, Celebrity Humanitarianism: The Ideology of Global Charity (London and New York: Routledge, 2013); D. Brockington, Celebrity Advocacy and International Development (New York: Routledge, 2014); and L. A. Richey (ed.), Celebrity Humanitarianism and NorthSouth Relations (New York: Routledge, 2015).

2 See, for example, Cohen, States of Denial; Chouliaraki, The Spectatorship of Suffering; Moeller, Compassion Fatigue; and Boltanski, Distant Suffering.

3 S. Franks, Reporting Disasters: Famine, Aid, Politics and the Media (London: C. Hurst \& Co., 2013), p. 3 .

4 Tester, Humanitarianism and Modern Culture, p. viii.

5 S. Cottle and G. Cooper, 'Introduction: Humanitarianism, Communications, and Change', in S. Cottle and G. Cooper (eds), Humanitarianism, Communications and Change (New York: Peter Lang, 2015), p. 4.

6 For a concise introduction to the origins of the modern international humanitarian system, see P. Walker and D. Maxwell, Shaping the Humanitarian World (London and New York: Routledge, 2009), pp. 13-45. For a critical analysis of the shifting (self) identity of contemporary humanitarianism, see M. Barnett and T. Weiss, 'Humanitarianism: A Brief History of the Present', in M. Barnett and T. Weiss (eds), Humanitarianism in Question: Politics, Power, Ethics (Ithaca: Cornell University Press, 2008), pp. 1-48. For an authoritative account of the development of humanitarianism since the nineteenth century, see M. Barnett, Empire of Humanity: A History of Humanitarianism (Ithaca and London: Cornell University Press, 2013). For critical discussions of earlier periods, see T. L. Haskell, 'Capitalism and the Origins of the Humanitarian Sensibility, Part 1', American Historical Review, 90:2 (1985), pp. 339-61 and 'Part 2', 90:3 (1985), pp. 547-66; T. Lacqueur, 'Bodies, Details and the Humanitarian Narrative', in L. Hunt (ed.), The New Cultural History (Berkeley, Los Angeles and London: University of California Press, 1989), pp. 176-204; T. Lacqueur, 'Mourning, Pity and the Work of Narrative in the Making of "Humanity"', in R. Wilson and R. Brown (eds), Humanitarianism and Suffering: The Mobilization of Empathy (Cambridge: Cambridge University Press, 2011), pp. 31-57; M. Abruzzo, Polemical Pain: Slavery, Cruelty and the Rise of Humanitarianism (Baltimore and London: The Johns Hopkins University Press, 2011), B. Simms and D. Trim (eds), Humanitarian Intervention: A History (Cambridge: Cambridge University Press, 2011), P. Stamatov, The Origins of Global Humanitarianism: Religion, Empires, and Advocacy (New York: Cambridge University Press, 2013), and R. A. Wilson and R. D. Brown (eds), Humanitarianism and Suffering: The Mobilization of Empathy (Cambridge and New York: Cambridge University Press, 2015).

7 Walker and Maxwell, Shaping the Humanitarian World, p. 2.

8 J. Benthall, 'Relief', in Akira Iriye and Pierre-Yves Saunier (eds), The Palgrave Dictionary of Transnational History (Basingstoke: Palgrave Macmillan, 2009), pp. 887-93; K. Rozario, " "Delicious Horrors": Mass Culture, The Red Cross, and the Appeal of Modern American Humanitarianism', American Quarterly, 55:3 (2003), pp 417-55. 
9 C. Calhoun, 'The Imperative to Reduce Suff ring: Charity, Progress, and Emergencies in the Field of Humanitarian Action', in M. Barnett and T. G. Weiss (eds), Humanitarianism in Question: Politics, Power, Ethics (Ithaca: Cornell University Press, 2008), p. 83.

10 For an analysis of the emergence of 'humanitarian government', or 'the deployment of moral sentiments in contemporary politics', and specifica ly 'the set of procedures established and actions conducted in order to manage, regulate, and support the existence of human beings', see D. Fassin, Humanitarian Reason: A Moral History of the Present, trans. R. Gomme(Berkeley, Los Angeles and London: University of California Press, 2012).

11 Barnett nd Weiss, 'Humanitarianism: A Brief History of the Pesent', p. 5, 7.

12 E. Bornstein and P. Redfi ld, 'An Introduction to the Anthropology of Humanitarianism', in E. Bornstein and P. Redfi ld (eds), Forces of Compassion: Humanitarianism between Ethics and Politics (Santa Fe: School for Adunced Research Press, 2010), p. 6.

13 Boltanski, Distant Suffering; Höijer, 'The Dscourse of Global Compassion', p. 515.

14 J. Silk, 'Caring at a Distance', Ethics, Place and Environment, 1:2 (998), p. 179.

15 Cottle nd Cooper, 'Introduction: Humanitarianism, Communications, and Change', p. 3.

16 Chouliaraki, The Spectatorship of Suffering, p. 1.

17 R. Belloni, 'The Trouble with Humanitarianism', Review of International Studies, 33:3 (2007), p. 456.

18 I. Smillie and L. Minear, The Charity of Nations: Humanitarian Action in a Calculating World (Bloomfi ld: Kumarian Press, 2004), p. 11

19 See A. Cooley and J. Ron, 'The NGO Scramble: Organisational Insecurity and the Political Economy of Transnational Action', International Security, 27:1 (2002), pp 5-39.

\section{References}

Abruzzo, M., Polemical Pain: Slavery, Cruelty and the Rise of Humanitarianism (Baltimore and London: The Johns Hopkins University Press, 2011).

Andersen, R. and P. L. de Silva (eds), The Routledge Companion to Media and Humanitarian Action (New York: Routledge, 2017).

Barnett, M., Empire of Humanity: A History of Humanitarianism (Ithaca and London: Cornell University Press, 2013).

Barnett, M. and T. G. Weiss, 'Humanitarianism: A Brief History of the Present', in M. Barnett and T. Weiss (eds), Humanitarianism in Question: Politics, Power, Ethics (Ithaca: Cornell University Press, 2008), pp. 1-48.

Belloni, R., 'The Trouble with Humanitarianism', Review of International Studies, 33:3 (2007), pp. 451-74.

Benthall, J., Disasters, Relief and the Media (London: I. B. Tauris, 1993).

Benthall, J., 'Relief', in Akira Iriye and Pierre-Yves Saunier (eds), The Palgrave Dictionary of Transnational History (Basingstoke: Palgrave Macmillan, 2009), pp. 887-93.

Boltanski, L., Distant Suffering: Morality, Media, and Politics, trans. G. Burchell (Cambridge: Cambridge University Press, 1999).

Borer, T. A. (ed.), Media, Mobilization, and Human Rights: Mediating Suffering (London and New York: Zed Books, 2012).

Bornstein, E. and P. Redfi ld, 'An Introduction to the Anthropology of Humanitarianism', in E. Bornstein and P. Redfi ld (eds), Forces of Compassion: Humanitarianism between Ethics and Politics (Santa Fe: School for Adunced Research Press, 2010), pp. 3-33.

Brockington, D., Celebrity Advocacy and International Development (New York: Routledge, 2014). 
Calhoun, C., 'The Imperative to Reduce Suff ring: Charity, Progress, and Emergencies in the Field of Humanitarian Action', in M. Barnett and T. G. Weiss (eds), Humanitarianism in Question: Politics, Power, Ethics (Ithaca: Cornell University Press, 2008), pp. 73-97.

Chouliaraki, L., The Spectatorship of Suffering (London, Thou and Oaks and New Delhi: SAGE, 2006).

Chouliaraki, L., 'The Th atricality of Humanitarianism: A Critique of Celebrity Adrocacy', Communication and Critical/Cultural Studies, 9:1 (2012), pp 1-21.

Chouliaraki, L., The Ironic Spectator: Solidarity in the Age of Post-Humanitarianism (Cambridge: Polity, 2013).

Cohen, S., States of Denial: Knowing about Atrocities and Suffering (Cambridge: Polity Press, 2001; revised 2017).

Cooley, A. and J. Ron, 'TheNGO Scramble: Organisational Insecurity and the PoliticalEconomy of Transnational Action', International Security, 27:1 (2002), pp. 5-39.

Cottl , S. and G. Cooper (eds), Humanitarianism, Communications and Change (New York: Peter Lang, 2015).

Cottl , S. and G. Cooper, 'Introduction: Humanitarianism, Communications, and Change', in S. Cottleand G. Cooper (eds), Humanitarianism, Communications and Change (New York: Peter Lang, 2015), pp 1-18.

Fassin, D., Humanitarian Reason: A Moral History of the Present, trans. R. Gomme(Berkeley, Los Angeles and London: University of California Press, 2012).

Fehrenbach, H. and D. Rodogno (eds), Humanitarian Photography: A History (New York: Cambridge University Press, 2015).

Franks, S., Reporting Disasters: Famine, Aid, Politics and the Media (London: C. Hurst \& Co., 2013).

Goodman, M. K. and C. Barnes, 'Star/Poverty Space: The Making of the "Development Celebrity"', Celebrity Studies, 2:1 (D11), pp 69-85.

Haskell, T. L., 'Capitalism and the Origins of the Humanitarian Sensibility, Part 1', American Historical Review, 90:2 (1985), pp 339-61 and 'Part 2', 90:3 (1985), pp 547-66.

Hesford, W., Spectacular Rhetorics: Human Rights Visions, Recognitions, Feminisms (Durham, NC and London: Duke University Press, 2011).

Höijer, B., 'TheDiscourse of Global Compassion: TheAudience and Media Reporting of Human Suff ring', Media, Culture and Society, 26:4 (2004), pp. 513-31.

Kapoor, I., Celebrity Humanitarianism: The Ideology of Global Charity (London and New York: Routledge, 2013).

Lacqueur, T., 'Bodies, Details and the Humanitarian Narrative', in L. Hunt (ed.), The New Cultural History (Berkeley, Los Angeles and London: University of California Press, 1989), pp. 176-204.

Lacqueur, T., 'Mourning, Pity and the Work of Narrative in the Making of "Humanity", in R. Wilson and R. Brown (eds), Humanitarianism and Suffering: The Mobilization of Empathy (Cambridge: Cambridge Universty Press, 2011), pp 31-57.

Lewis, D., D. Rodgers and M. Woolcock (eds), Popular Representations of Development: Insights from Novels, Films, Television and Social Media (London: Routledge, 2014).

Linfi ld, S., The Cruel Radiance: Photography and Political Violence (Chicago andLondon: University of Chicago Press, 2010).

Moeller, S., Compassion Fatigue: How the Media Sell Disease, Famine, War and Death (Londonand New York: Routledge, 1999).

Orgad, S., 'Imagining Others: Representations of Natural Disasters', in Media Representation and the Global Imagination (Cambridge and Malden, MA: Polity Press, 2012), pp. 52-80. 
Richey, L. A. (ed.), Celebrity Humanitarianism and North-South Relations (New York: Routledge, 2015).

Robinson, P., 'News Media and Communications Technology', in R. M. Ginty and J. H. Peterson (eds), The Routledge Companion to Humanitarian Action (AbingdonandNew York: Routledge, 2015), pp 254-66.

Rotberg, R. I. and T. G. Weiss (eds), From Massacres to Genocide: The Media, Public Policy and Humanitarian Crisis (Washington, DC: The Brookings Institute/Cambridge, MA: The World Peace Foundation, 1996).

Rozario, K., '“Delicious Horrors”: Mass Culture, The Red Cross, and the Appeal of Modern American Humanitarianism', American Quarterly, 55:3 (2003), pp 417-55.

Silk, J., 'Caring at a Distance', Ethics, Place and Environment, 1:2 (998), pp. 165-82.

Simms B. and D. Trim (eds), Humanitarian Intervention: A History (Cambridge: Cambridge University Press, 2011).

Smillie, I. and L. Minear, The Charity of Nations: Humanitarian Action in a Calculating World (Bloomfi ld: Kumarian Press, 2004).

Stamatov, P., The Origins of Global Humanitarianism: Religion, Empires, and Advocacy (New York: Cambridge University Press, 2013).

Tester, K., Compassion, Morality and the Media (Buckingham and Philadelphia: Open University Press, 2001).

Tester, K., Humanitarianism and Modern Culture (Pennsylvania: Penn State Press, 2010).

Walker, P. and D. Maxwell, Shaping the Humanitarian World (London and New York: Routledge, 2009).

Wilson, R. A and R. D. Brown (eds), Humanitarianism and Suffering: The Mobilization of Empathy (Cambridge and New York: Cambridge University Press, 2015). 


\section{Part I}

Histories of humanity 



\section{1 \\ 'United Nations children' in Hollywood cinema: Juvenile actors and humanitarian sentiment in the 1940s}

\section{Michael Lawrence}

Th s chapter examines specificideologicaland aesthetic dimensions of the representation of children in American films produced during and directly after the Second World War in relation to the promotion and operations of the United Nations. ${ }^{1}$ It addresses how pitiable and vulnerable children from the world's warzones - specifi ally groups of orphaned, abandoned and injured children from diff rent countries appeared and functioned in four Hollywood studio pictures: Twentieth Century Fox's suspense thriller The Pied Piper (Irving Pichel, 1942), Universal's romantic musicalThe Amazing Mrs Holliday (Jean Renoir/Bruce Danning, 1943), RKO’s comedian comedy Heavenly Days (Howard Estabrook, 1944) and RKO's family fantasy The Boy with Green Hair ( Joseph Losey, 1948). I explore how these films presented groups of children to harness humanitarian sentiment in support of the ideology and activities of the UN, and consider the critical response to (and a director's refl ctions on) the juvenile actors who appeared in the films; while the figure of the child acquired new cultural and pditical signific nce in the era of the UNs wartime and post-war humanitarian endeavours, the presentation and performance of the Hollywood child actor simultaneously became subject to new modes of aesthetic apprehension and evaluation.

As Liisa H. Malkki has suggested, children are 'central to widely circulating representations of "humanity"that are foundational to the whole aff ctive and semiotic apparatus of concern and compassion for "the human" that underlies practices of humanitarian care. ${ }^{2}$ Malkki is concerned with 'tracing aff ct and sentiment in the humanitarian and humanistic uses of children' (103), and draws on the work of Ann Stoler, who argues that consent (to the state) is made possible 'by directing aff ctive judgments', and 'by educating the proper distribution of sentiments and desires.' The images of children presented by Hollywood contributed to the 'aff ctive and semiotic apparatus' appropriate for a new era of global humanitarianism. Raymond Williams described 'structures of feeling' as 'aff ctive elements of consciousness and relationships: not feeling against thought, but thought as felt and feeling as thought: practical consciousness of a present kind, in a living and interrelating 
community'. A humanitarian 'structure of feeling' crystallises around an aff ctive beholding of a group of displaced and dispossessed children; the groups themselves off $r$ a sentimental model of a supranational 'interrelating community'. Judith Butler's analysis of the 'conditions under which it becomes possible to apprehend a life or set of lives as precarious' is useful for thinking about how the children in these films functioned to produce 'aff ctive and ethicaldispositions' concerning the suff ring of distant others. ${ }^{5}$ Butler argues that apprehension, as distinct from recognition, 'is boundup with sensing and perceiving, but in ways that are not always - or not yet - conceptual forms of knowledge'. Hollywood films invited precisely such an apprehension of both the child and the obligation to help her; they produced a humanitarian sentiment appropriate for the 'practical consciousness' required by mid-century internationalism. As a short New York Times article proclaimed in November 1943: 'Thesaddest, dreariest, most heartbreaking aspect of modern war is not battl , in which the soldier has literally a fighting chance. It is among civilians in occupied areas. Old people and children suff r most, andof those two thechildren are the most sorrowful spectacle.7 Herbert H. Lehman, the director of the United Nations Relief and Rehabilitation Adminstration, stated in his November 1943 acceptance address: 'We must be guided not aloneby the compelling force of human sentiments butalso by dictates of sound commonsense and of mutualinterest.' ${ }^{8}$ However, it is to those 'human sentiments' that Hollywood cinema's 'sorrowful spectacle' of suff ring children (sorrowful meaning both showing and causing grief) is most likely (and, perhaps, solely) to appeal; as Lilie Chouliaraki has suggested, 'pure sentimentalism ... cancels out its own moral appeal to action."

Tara Zahra suggests the Second World War 'was not only a moment of unprecedented violence against children ... [it] also spawned ambitious new humanitarian movements to save and protect children from wartime upheaval and persecution. ${ }^{10}$ As Dorothy Stephenson, writing in the New York Times in November 1943, declared: 'If there are any priorities among war victims when the United Nations Relief and Rehabilitation Adminstration embarks on its mission of mercy after the war, the children come fi st. ${ }^{11}$ For DominiqueMarshall, the child, as a privileged focus of global humanitarian endeavour, was of particular signific nce in the attempt 'to channel the humanitarian movements of wartime toward international cooperation in peacetime. ${ }^{12}$ The children presented in Hollywood's war-themed films functioned to solicit and shape humanitarian sentiments that were central to popular support for the UN as an organisation and the 'one world' vision it was understood to herald. Wendell L. Willkie, in his bestselling book One World, warned 'if hopeful billions of human beings are not to be disappointed, if the world of which we dream is to be achieved, even in part, then today, not tomorrow, the United Nations must become a commoncouncil, not only for the winning of the war but for the future welfare of mankind. ${ }^{13}$ Popular cinema was a powerful means with which to promulgate and promote this view: indeed, in 1945, Dorothy B. Jones, former head of the Film Reviewing and Analysis Section of the Hollywood division of the Office of War Infomation, 
suggested in a world shattered by conflict it has become increasingly evident that only through solidly founded and dynamic understanding among the peoples of the world can we establish and maintain an enduring peace. At the same time it has become clear that the film can play an impotant part in the ceation of One Wrld.14 In her discussion of 'the United Nations themein pictures', Jones notes how the 'sympathetic portrayal of our allies aided in increasing American world-mindedness' and '[contributed] ... to a better understanding among the people of the United Nations. ${ }^{15}$ More recently, Julie Wilson has shown how ' $[$ the] atrocities and devastation of World War II ... affo ded the principles of international cooperation and a shared, common humanity new cultural signific nce. ${ }^{16}$ In her analysis of 'cultural diplomacy programs and "one world" visions' Wilson suggests 'new and expanding conceptions of internationalism and citizenship made their way into popular culture via sentimental discourses that emphasized emotional, common bonds between Western citizens and distant others.' ${ }^{17}$ Wilson draws on Christina Klein's work on Hollywood cinema and post-war international relations: for Klein, sentimental narratives 'uphold human connection as the highest idea and emphasize the forging of bonds and the creation of solidarities among friends, family, and community'. The sentimental is 'a universalizing mode' that both 'imagines the possibility of transcending particularity by recognizing a commonand shared humanity' and 'values theintensity of theindividuals felt experience, andholds up sympathy — the ability to feel what another person is feeling, especially his suff ring-as the most prized. ${ }^{18}$ As such, the sentimental is an ideal modefor promoting the UN: ToddM. Bennett, in One World, Big Screen: Hollywood, The Allies and World War II, argues '[wartime] diplomats, propagandists, and media moguls mobilized popular culture, especially cinema, to ... create from scratch an imagined international community' and sought to give civilians 'an emotional investment in the United Nations. ${ }^{19}$ Bennett examines how Hollywood deployed 'kinship discourses' - 'international romances, fraternal combat epics, or paternal fantasies' to '[facilitate] the big screen's one-world sensibility by emotionalizing inter-Allied relations'; the signific nce of the child, however, and of paternal, maternal or parental sentiments, for Hollywood's 'emotionalizing' of both inter-Allied relations and the $\mathrm{UN}$, requires further examimation. ${ }^{20}$ Hollywood cinema's representation of vulnerable foreign children in these films sometimes challenged and sometimes typifi $\mathrm{d}$ the industry's conventional and sentimental representation of children as appealingly cute. As Lori Merish has argued, cuteness engenders a 'formalized emotional response': 'the cute stages ... a need for adult care.21 The juvenile actors appearing in these films, moreover, were apprehended (by critics) as either challenging or typifying traditions of juvenile performance in American commercial cinema, with a restrained 'realism' (an appealing but not appalling authenticity) regarded as a more appropriate register for even popular entertainments concerned with the war's most vulnerable victims. Hollywood's humanitarian representations of the child's 'need for adult care', however, were vulnerable themselves to (charges of) a mercenary and manipulative cuteness. 
Sentimental modes of representation will be examined here to consider the efficacy of Hollywood films (and the juvenile actors who worked on them) in communicating particular ideas about the UN and providing audiences with an aff ctive apprehension and experience of those ideas. Richard Patterson, writing in 1951, discussed the establishment in 1946 of the Film Division of the UN Department of Public Information, which, in addition to making newsreels and documentaries, sought 'to interest the [Hollywood] studios in using occasional episodes and turns of plot that might condition audiences to accept the UN as part of their daily lives' so that 'the stereotyped image of an organization given to unpleasant wranglings and haranguings would be replaced by the truer impression of high purposes and humanitarian actions. ${ }^{22}$ Following the end of the war, in August 1946, the fifth Council session of the United Nations Relief and Rehabilitation Adminstration (UNRRA) in Geneva decided the agency would be integrated into the UNO, following its liquidation in October, but one of its closing actions was 'to establish an international children's fund for care of minors in liberated countries. ${ }^{23}$ A year later, in October 1947, Gertrude Samuels accused the ICEF (International Children's Emergency Fund) of failing the tens of millions of children in Europe and Asia, but welcomed the plans for a UN Appeal for Children in $1948 .{ }^{24}$ For Chester Bowles, Chairman of the International Advisory Committee for the UN Appeal for Children, the appeal sought to support the work of the ICEF 'by asking individual men and women all over the world to fill in the gap left by their governments': the Appeal was 'a challenge to every parent, every worker, farmer and business man who seeks to build a world of peace and understanding. ${ }^{25}$ Reporting on this 'truly global' appeal, the New York Times stated 'people in many nations have shown a readiness to act as world ditizens. ${ }^{26}$

The groups of children in my chosen films provide appealing images of international unity (the children act as one even when they speak diff rent languages) and thus off $r$ a sentimental idealisation of the organisation itself, as well as of the children the organisation's 'humanitarian actions' sought to help, with the aid of ordinary Americans' charitable support. Thegroups of children represent miniature international societies in which the specific nationality of each member matters less than their material vulnerability as children. United by the 'aff ctive authority' Malkki suggests is conventionally att ibuted to children, these groups function as triggers for sentimental modes of internationalism and humanitarianism appropriate for the UN era. ${ }^{27}$ Bonds of aff ction forged between American adults and foreign children in the fi st three films provide a model for the audiences' imaginative and empathic apprehension of the suff ring of other distant children; in the fourth film, the American child protagonist appears to 'imagine' (dream or hallucinate) a group of suff ring foreign children, and then directly addresses the camera, challenging the audience to (in Butler's terms) 'apprehend a life or set of lives as precarious. ${ }^{28}$

In The Pied Piper, hereafter Piper, an elderly gentleman (Monty Wooley) holidaying in France in the summer of 1940 reluctantly agrees to chaperone two 
British children (RoddyMcDowall and Peggy Ann Garner) back to London Thei party is joined by several further children, of diff rent nationalities, and is captured by the Nazis, but eventually reaches England, from where the children travel to the United States; the events are presented as a flashback when Wooley's character recounts his adventures at a London club. According to one contemporary critic, the film concerned 'an austere British greybeard upon whom devolves the unwonted task of shepherding an increasing flockof refugee kids across war-racked France at the time of the Nazi breakthrough.'29 In The Amazing Mrs Holliday, hereaft $\mathrm{r}$ Holliday, a young missionary (Deanna Durbin) arrives in San Francisco having fl d China along with a group of orphans of various nationalities, and pretends to be the widow of a Commodor Holliday (who disappeared when their ship was torpedoed) so that the children can enter the United States. As one critic put it, the film presented 'the account of a young American school teacher in China who manages to smuggle nine assorted moppets aboard a homeward-bound ship. ${ }^{30}$ In the more whimsically episodic Heavenly Days, hereafter Heavenly, Jim and Marian Jordan (Fibber and Molly McGee), visiting Washington, encounter a group of children from various countries while hiding out in the house of a senator who has arranged for their adoption, or, in the words of the critics, 'get tangled up charmingly with a group of multi-tongued refugee kids' and 'act as guardians to a group of United Nations orphans. ${ }^{31}$ In The Boy with Green Hair, hereafter Boy, an American war orphan (Dean Stockwell), whose parents were killed in the Blitz, takes part in his school's war orphan charity drive, and then discovers (dreams or imagines) a group of war orphans in a forest glade. For one critic the film was 'a novel and noble endeavour to say something withering against war on behalf of the world's unnumbered children who are the mo\$ piteous victims thereof'. ${ }^{32}$

Thegroups of children presented in the films gradually grow in size (sixin Piper, nine in Holliday, eight in Heavenly and ten in Boy) and, more importantly, are increasingly international in constitution. The 'floc' in Piper comprises British, French, Dutch and German children; the 'assorted moppets' in Holliday include European or Australian children from Vietnam, China, Hong Kong, Singapore and Burma, and a Chinese baby; the 'multi-tongued refugee kids' in Heavenly are from Czechoslovakia, Greece, England, France, Belgium, the Netherlands, China and the Soviet Union; the children in Boy, whose nationalities aren't specifi $\mathrm{d}$ as such, are based on images of children on the posters on display at Peter's school promoting specific relief campaigns (for children in Greece, Yugoslavia and China, and for Jewish children), and a photograph labelled simply 'Unidentifi d War Orphan'. Heavenly's group most clearly represents the UN (with children from England, France, China and the Soviet Union); the director's original outline of the story describes them as 'orphan refugee children, four to eight years old, representing the principal countries of the United Nations, including Chinese [sic]' and then simply 'the United Nations children. ${ }^{33}$ The children, however, occupy increasingly marginal positions in their respective films: in Piper they 
are central to the rescue narrative and in Holliday they are the backdrop to the romance plot, while in Heavenly they feature in just a couple of scenes and in Boy they appear in a fi e-minute dream sequence. All fourfilms, however, accord with James Chandler's account of the sentimental mode in Hollywood cinema. For Chandler, sentiment, or 'distributed feeling', is 'dependent on a relay of regards', produced in the Hollywood film via cinematography and editing, patterns of close-ups, reverse shots and eye-line matches. ${ }^{34}$ In these films, the groups of children are encountered as 'sorrowful spectacles' by the protagonists; the audience member thus 'beholds what amounts to a mutual beholding on the part of two other parties', which, for Chandler, is 'a hallmark of the sentimental mode and its way of making a world. ${ }^{35}$ Scenes of mutual beholding occur in liminal spaces, thresholds and borders as the children journey towards and arrive in the United States: in the fi st three films, when the children are ushered inside a safe house in France (Piper), escorted into San Francisco (Holliday) or chaperoned into a senator's mansion in Washington (Heavenly); in Boy, the children appear in an American child's dream or inagination.

Th se Hollywood films are deserving of attention precisely because the stories revolve aroundor feature children displaced, dispossessed, terrifi $\mathrm{d}$ and traumatised by the war, subject matter more commonlyassociated with the 'new' realist European cinemas of the immediate post-war period. The Hollywood films were produced several years before American audiences (at least those in metropolitan centres) were able to see the neorealist films from Europe. Ths cinema often privileged the experiences and perspectives of children and featured non-professional child performers in leading roles; well-known examples include Vittorio De Sica's Shoeshine (Italy, 1946 [released in the United States in 1947]), Gerhard Lamprecht's Somewhere in Berlin (East Germany, 1946 [1949]), Robert Rossellini's Germany Year Zero (Italy, 1948 [1949]), Geza Radvanyi’s Somewhere in Europe (Hungary, 1947 [1949]), and Aleksander Ford's Border Street (Poland, 1948 [1950]). In his discussion of children in post-war European cinema Pierre Sorlin refers to filmmakers 'running the risk of having recourse to juveniles who were not even amateur actors and who seldom made a career in cinema', and suggests '[as] they were not professional, the young actors could not remember long lines and their dialogues were necessarily short. ${ }^{36} \mathrm{Th}$ s, however, helped the films: 'theydid not communicate ideas marked by words but raised sentiments and feelings aff cting the disposition of the spectators' minds. ${ }^{37}$ In the opening pages of Cinema and Sentiment (1982) Charles Affron states: 'Art works that create an overtly emotional response in a wide readership are rated inferior to those that engage and inspire the refin $\mathrm{d}$ critical, intellectual activities of a selective readership', but then reminds us that 'the works of the Italian neo-realist directors ... immediately recognized by intellectuals as challenging and by general audiences as "art," are awash with the same trappings of sentimentality ... that are often considered negative in "commercial" narrative films. ${ }^{38}$ Karl Schoonover has discussed the international reception of Italian neorealism in 
relation to 'the emergence of a new visual politics of liberal compassion' and argues that for both American and European commentators alike 'an emergent realist aesthetic of cinema could build new vectors of post-war globalism. ${ }^{39}$ In De Sica's cinema, for example, realist devices were 'capable of triggering and nourishing a charitable gaze in line with the nascent institutional practices of global humanism. ${ }^{40}$ Theinflu nce of European neorealism on American cinema is usually discerned in films produced at the end of the 1940s, such as Fred Zinnemann's The Search (1948) and George Seaton's The Big Lift (1950), both of which were filmed on location in Europe, butHollywood studio films had since the early 1940 s off red audiences commercial and sentimental entertainments in which the 'realistic' representation of the war's impact on children was regarded as innovative and progressive, and seemed designed to '[trigger] and [nounish] a charitable gaze' appropriate for the humanitarian sentiment upon which the UN's popularity depended. ${ }^{41}$ Th se Hollywood films thus preceded and anticipated European neorealism due to their sentimental and realistic representations of the suff ring of children from the warzones. When, reviewing Rosselliniss Germany Year Zero, André Bazin declared 'the days of Shirley Temple [were] now over', he meant not only that the war demanded more honest stories about children's lives, but that such films would require a new style of juvenile performance. ${ }^{42}$ But if Temple had provided the dominant model of the accomplished and irresistible child star during the 1930s, then the children who featured most prominently in Hollywood productions of the early to mid 194os - Margaret O’Brien, Roddy McDowall, Peggy Ann Garner, Claude Jarman Jr, Elizabeth Taylor - were celebrated for their sensitivity and subtlety as 'actors' and were widely seen as inaugurating a more realistic style of juvenile performance, in starkcontrast to the precociousposturing of entertainers like Temple and in keeping with the more serious dramatic roles being given to children at this time. In a 1945 LIFE feature about the shift from child stars 'who relied more heavily on theirtalent for being likeable than on their ability to portray complex character' (such as the 'curly-haired, doll-like Shirley Temple') to the young 'dramatic actresses' of today, who share 'a remarkable faculty of appearing perfectly natural before the camera', Garner is described as 'a severely plain little girl' and 'the most perfect example of today's trend towards realism in child acting. ${ }^{43}$ The desire for and apprehension of new and 'natural' styles of juvenile performance during the war - what Alexander Nemerov has called 'the Temple-O'Brien axis', whereby saccharine cuteness and overt innocence 'fell out of favour' with audiences and critics alike - thus precedes by several years the revelatory authenticity of the non-professional child actors in the European neorealist films. ${ }^{44}$ Tracking evaluations of the child's appearance and performance in Hollywood's war-themed films reveals surprising continuities between American and European cinema, and suggests how humanitarian sentiment appropriate for and conduave of a 'one world' sensibility was produced by both Hollywood's professional juvenile actors and neorealism's non-professional child performers. 


\section{The Pied Piper (1942)}

Uponthe film's release, the New York Times announced 'From Nevil Shute's novel of the war's saddest flot am, the children, Twentieth Century Fox has created a warm, winning and altogether delightful film. ${ }^{45}$ The success of Piper might be explained by the balance it maintains: as one critic put it, "[stern] realism has held the sentiment within bounds so that it never becomes obnoxious. ${ }^{46}$ The studio's press book described the film as demonstrating Hollywood's new maturity, due to the 'dignity', 'restraint' and 'realism' with which it '[focuses] on the quieter drama of civilian life'. LIFE magazine concurred that the film demonstrated the 'subtlety and sense' with which Hollywood was capable of responding to 'the human rights now at stake. ${ }^{37}$ Critics agreed that the performances by the film's 'Remarkable Group of Child Actors' were integral to its realism, restraint and subtlety: one critic declared 'where children on the screen are apt to be either unbearably dull or unbearably precocious, Roddy McDowall leads as sincere and appealing a group of youngsters as we've seen' and another suggested '[as] a group these children come pretty close to establishing a new high for the portrayal of children in American-made movies', adding 'the fact of genuine child-like quality cannot be denied. ${ }^{48}$ The authenticity of the children's performances could in certain cases be att ibuted to their own reallife experiences: newspapers routinely mentioned that the cast included actualchild evacuees from Europe. Not onlywas McDowall a genuine 'British evacuee star' but Fleurette Zama, who played the French girl Rose, as one review pointed out, 'was one of those who fl $\mathrm{d}$ from Paris just a few hours before the Nazis marched into the city and who, with other refugees, walked under a rain of bullets from German planes that strafed the crowded roads. ${ }^{49}$

In terms of representing individual humanitarian endeavour, the film off $\mathrm{rs}$ audiences someone who neither plans to save any children nor flinches from his duty despite the dangers involved, even when the party is captured by the Gestapo and he is threatened with torture. The film makes it clear that John's understanding of his responsibility grows as the number of children in his care increases, and that it is the children's intuitive solidarity, the group's hospitality to outsiders - which takes place between scenes, and off screen - which establishes a standard for his own actions. As one review stated, 'waif by waif-a French girl, a fear-haunted boy orphaned by Nazi strafers, a shave-headed Dutch lad unaccountably lost in Chartres - the old man's resistance to his Pied Piper destiny en route is charmingly overcome by the curious, instinctive humanity of children toward one another.50 Around a third of the way into the film, John, with four children (Ronnie, Sheila, Rose and Pierre [Maurice Tauzin]) in tow, arrive at the house of his dead son's former French girlfriend, Nicole Rougeron (Anne Baxter). At the front door, John explains that they desperately need a place to spend the night. Nicole invites them inside where they are met by her mother, who welcomes John into the front parlour while the children wait in the hall. In a continuous medium shot from inside the 
room, John then rather formally introduces the children one by one as they enter the parlourfrom the hall, accompanied by orchestral music on the soundtrack (it is the melody associated with the children's nursery rhyme 'Twinkle Twinkle Little Star', based on Mozart's arrangement). Ronnie, Sheila, Rose and Pierre enter the parlour in turn and stand with the adults, after which John is surprised to discover a fifth child (Merrill Rodin) by his side, at which point the music pauses. Thenext shot is from over and behind John's shoulder, showing the boy looking up at him and then hanging his head (he is dirtier than the other children, his hair has been shaved off, and he has a large open sore on his forehead) and the following shot is from under and behind the boy's shoulder, showing John looking down at him in amazement. The camera's position, behind their shoulders, emphasises the mutual beholding presented to the audience. Thefilm then cuts to another mediumshotof the parlour, from behind the boy's head, showing the 'relay of regards' as the other characters look at the boy and at each other. Themusic resumes as Sheila explains to John how the boy came to join the group. John, and with him the film's audience, are suddenly confronted with a more distressing image of the war's impact on children; the boy's appearance is similar to that of the children documented by photographers such as Th rese Bonney (whose collection Europe's Children was published the following year); he embodies what Giorgio Agamben would later term 'bare life. ${ }^{51}$ The critic for the New York Post, noting that '[every] youngster Howard acquires ... has his own individuality and each presents a special problem', suggests that this littleDutch boy, 'lovable because of his sores and his dirt' must have '[passed] through the Nazi decontamination machine. ${ }^{52}$ Th s scene of 'mutual beholding' fuses suspense, comedy and humanitarian sentiment. John is somewhat exasperated as to how the boy has joined them (Wooley excelled at befuddlement) but Ronnie and Sheila explain that 'Willem' has actually been with them 'on and offsince yesterday' (this is, however, the fi st time we have seen him - the film is told from John's point of view) and that even though none of the children know Dutch (they have or are French) they had made it clear to the boy that he was welcometo join them. ${ }^{53}$ Theincrease in realism produced by Willem's arrival is simultaneous, then, with a rather sentimental account of international relations - the children's humanitarian hospitality - that utterly bamboozles John, who must abandonany desire for a rational explanation of the spontaneous solidarity, and what he calls the 'system of Lilliputian communica tion', demonstrated by the goup of chldren under his care.

At the very end of the film, John is asked to take with him a Gestapo officer's niece, who is brought to the harbour where the party are preparing to set sail: yet another child joins their group. Signific ntly, this little girl, Anna ( Julika) - unlike Sheila or Rose - is extremely pretty (or rather prettifi d), a proper poppet. 'Thedays of Shirley Temple' (Bazin) are quite clearly evoked by Anna (and the little doll she clutches). Her arrival late in the film is important fortwo reasons: fi st, and following Shute's novel, the film shows John's humanitarian endeavour as profoundy inclusive - the group of children, by the time the film ends, includes both 'Allied' and 
'Axis' children on the boat bound for England. ${ }^{54}$ Second, the way Anna is styled and behaves (and Julika's performance), compared with the other children in the film, arguably imbues the earlier style named in Nemerov's 'Temple-O'Brien axis' with a mechanical precision here explicitly associated with Nazism (most apparent when Anna greets John with a dainty 'Heil, Hitler!' salute) while the other children (and the other child actors) appear, by contrast, as athentic, ordinary individuals.

\section{The Amazing Mrs Holliday}

The Amazing Mrs Holliday, on which the French director Jean Renoir worked for several weeks before being replaced by the film's producer Bruce Manning, was intended to provide the popular teenaged singing sensation Deanna Durbin with a more grown-up and serious image. Following Renoir's departure, the studio demanded a more conventional and commercial product, which explains the film's sometimes awkward blend of romantic comedy (in the San Francisco scenes) and realism (in the China scenes), and its ultimate recourse to a sentimental modewith which to educate its audience about the urgent need for international humanitarian endeavour in China. The reconciling of cultural internationalism with the imperatives of commercial entertainment is perhaps best encapsulated by the sequence in which Ruth sings 'Rock-a-bye Baby' to the children in flu nt Mandarin. Nevertheless, for William K. Everson (writing in the 1980s) Holliday is 'probably (in a relative sense since the story is somewhat artifi ial) the most realistic and certainly the least glossy (in terms of production techniques) of all the Dubin films. ${ }^{55}$

The film received mixed reviews: for the Motion Picture Herald it was 'a heartwarming story of the war's homeless children, with a good measure of comedy to leaven the sentiment', featuring 'nine waifs of uncertain origin and undeniable appeal', who 'will enchant the audience by just being themselves'.56 But for the New York Times, the film lacked the understanding and grace' of The Pied Piper, and was clumsy, 'contrived and crude', 'a trivial story upon a theme much too sensitive and real to be exploited in such shoddy fashion, in which 'the authors at no point show any real concern for the children; they are merely scattered through the scenes to serve as a sort of pathetic background for Miss Durbin's display of mother-love' and 'presented in such an awkward and stilted style that one never senses any poignance in theirinsecure lives'; Durbin's rendition of the Chinese lullaby, furthermore, was simply sacrifi ing the genuine for the ate..$^{37}$

The flashback sequences showing the bombing of the orphanage in China, usually att ibuted to the original director Jean Renoir, however, are only slightly less harrowing than the scenes that conclude China Girl (Henry Hathaway, 1942), released a few months before, in which Johnny (George Montgomery), an American cameraman working in occupied China, falls in love with Haoli, a Chinese woman (Gene Tierney) who runs an orphanage with her father. When the Japanese bomb the orphanage, the father and several orphans are killed outright; Haoli is killed 
trying to rescue the remaining children. One critic suggested that '[the] last scenes of frightening realism should not be seen by children, indeed one does not like to see the Chinese children acting in them', and concluded that '[it] is a moot point whether scenes of death and destruction should be used for entertainment, even from the highest motives. ${ }^{58}$ In One World, Big Screen Bennett argues Haoli's death in China Girl results in Johnny's 'reformationinto a committed internationalist warrior' and the film's tragic romance thus 'symbolized and lent emotional sustenance to the actual Sino-American partnership. ${ }^{59}$ The 'kinship discourse' deployed in Holliday, however, revolves around Ruth's intensely felt maternal responsibility for the group of international children; this prompts her to masquerade as the Commodore's widow, and this pretence is the obstacle to her relationship with the Commodoe's son. While the film is topical, it abides by the conventions of the romantic musical However, it begins with a scene of 'mutual beholding' in which the orphans' harrowing experiences in the warzones are described (rather than dramatized) for both the immgration officer in the film and the audience of thefilm.

The scene begins with two shots that bring us closer to a group of children as a young woman tells them aboutSan Francisco, where they will shortlyland. Ruthand the children all look over to the left as the inspector from the Immigration Service arrives. Standing to face him, Ruth tells the inspector that while she is not related to the children, they are 'just like a family'. The inspector asks Ruth whether the children have any documents, and she answers that they have no 'formal passports'. 'What kind do they have?' he asks her. 'Thesamekindall children have during a war', she replies, at which point the film cuts to a group shot of the children, from Ruth's perspective, and she explains: 'Fear and need of shelter.' Ruth volunteers to tell the inspector everything she knows about Marie, Rodney, Winifred, Teddy, Elizabeth, Anna and Vido, and a (Chinese) baby. While she does this, the film shifts between medium shots of the group of children sat on the deck, approximating the perspective of the adults, close-ups of the faces of the individual children as Ruth narrates their particular circumstances, in which each child raises their eyes to meet the adults gaze, before dropping theirheads (just like Willem in Piper), and a medium shot of Ruth and the inspector looking down at the children (figures 1.1 and 1.2); there is, rather surprisingly, no music on the soundtrack during this sequence. Of Teddy, for example, Ruth explains 'his father was a doctor in a hospital near our village - the Japs [sic] took his parents prisoner and left Teddy there to die - they didn't know Teddy - he crawled two miles to a road - a Chinese soldier brought him to us'; of Marie, 'Her father had a petrol station by a river near our school - the Japs [sic] needed fuel for their boats - she hasn't seen her mother or father since'. Once Ruth and the children have disembarked a senior immigration officer tells her each child requires a $\$ 500$ bond; the children watch from a nearby bench, at which point Ruth promises them she will return for them as soon as she can (after presenting herself as the Commodoe's widow, she and the children move into the Holliday mansion). During the relay of regards' in these scenes, characters view the 


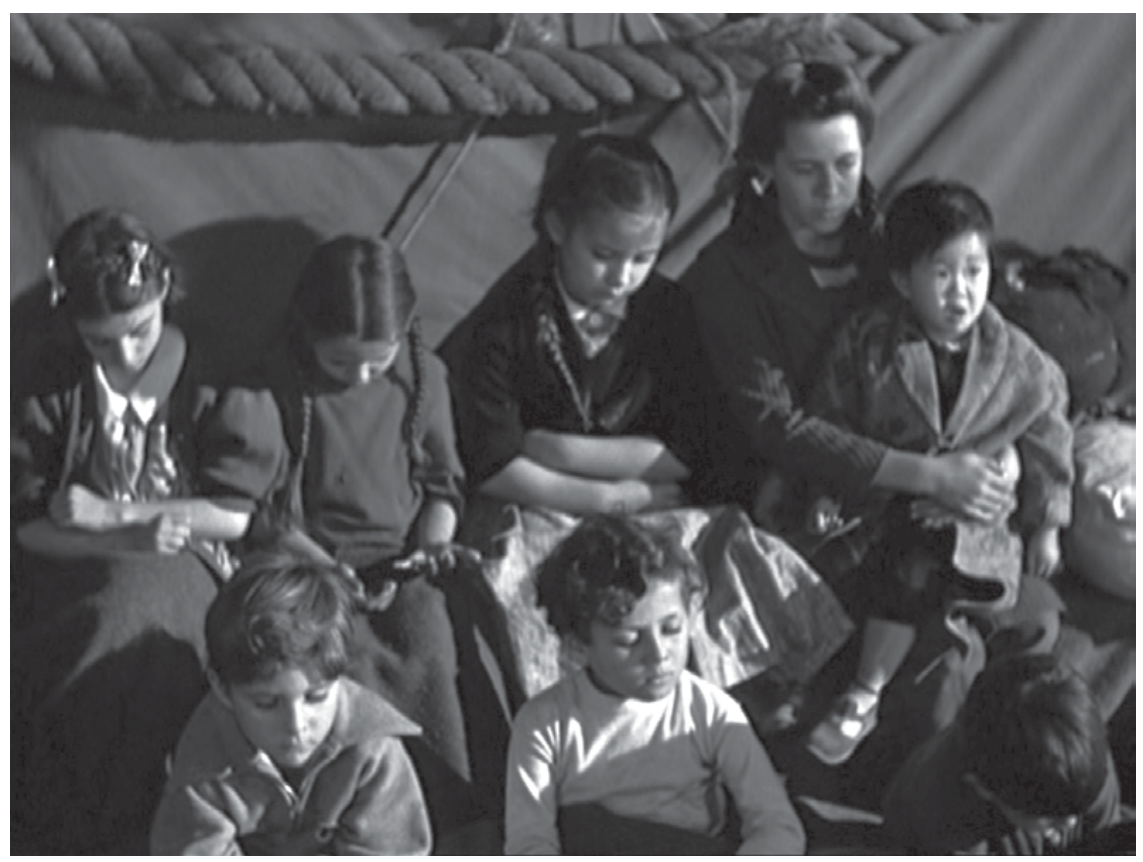

Figure 1.1 The Amazing Mrs Holliday

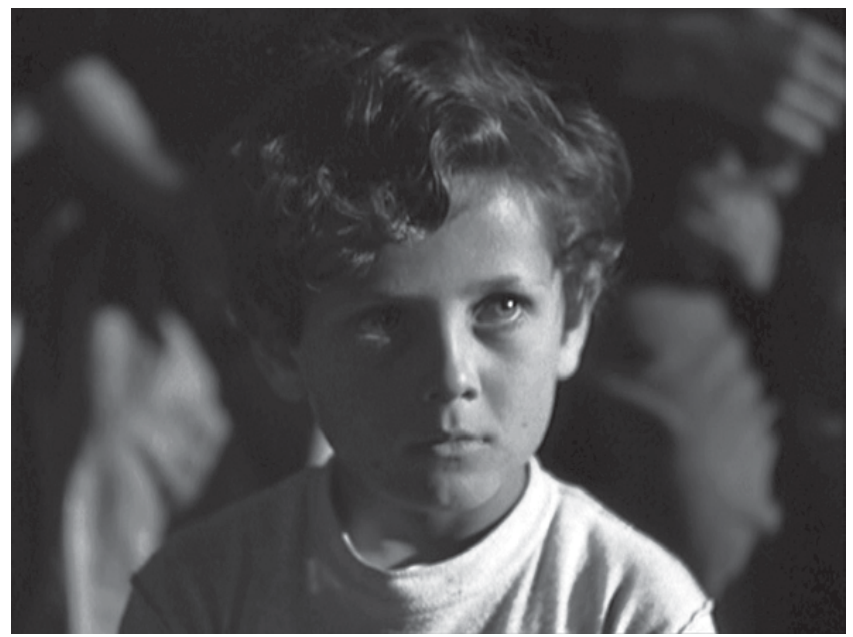

Figure 1.2 The Amazing Mrs Holliday 
children in diff rent ways, often in the same shot: Ruth sees them as her family (her children), but the immigration officers see them simply as a case to be processed according to the regulations, despite their being subjected to the same appealing gaze of the children. Thechildren seem to recognise their own precariousness, how they can be apprehended simultaneously by both a sentimental (here, maternal) and a bureaucratic humanitarian gaze. The lack of over-the-shoulder shots in the sequence situates the film audience more securely in the actual position occupied by, fi st, the adults looking down at the children and, second, the children looking up at the adults. The film thus invites the audience to evaluate the conflict between Ruth's 'sentimental' idealism (regulations shouldnot prevent her from carrying out her responsibilities) and the inspectors' objective 'sense' (responsibility for children requires regulations), but ultimately, and inevitably, endorses Ruth's subterfuge. It is this subterfuge, after all, which provides the romantic plot with the conventional element of uncertainty regarding the heroine's eventual marital happiness. While the film establishes very clearly at the start that the claim of the child upon the adult, as the more positive critic suggested of the child actors' appeal, inheres in children 'just being themselves' (that is, children), its obeisance to the conventions of the romantic musical inadvertently demonstrates how a just response to the child's claim is all the more necessary given how often children are marginalised, or, as the negative review put it relegated by adults' affai s to a mere 'pathetic background.

\section{Heavenly Days}

For one critic Heavenly was 'a heartening if not always tip-top example of how even straight comedy can be relevant and constructive'; for another it was 'an example of how a picture can be both instructive and entertaining', and off red specificaly 'a preachment for more active participation in public affai s on the part of the average citizen and for better understanding among national groups. ${ }^{60}$ Th se 'national groups' are embodied in the film by 'a young league of nations that demonstrates diff rent international groups can live harmoniouslywith one another', or, as the script described them, the United Nations children. ${ }^{6}$

In the sequence in which the McGees fi st encounter the war orphans, around halfway through the film, they are posing as domestic servants in a senator's mansion in Washington; the arrival of the children (chaperoned by adults of various nationalities) is somewhat similar to the children's arrival at the mansion in Holliday, while the admission of another orphan (after the McGees have closed the door) is similar to John's encountering 'yet another' child at the door of the parlour in Piper. The scene of 'mutual beholding' proceeds as the 'United Nations children', attired in national costumes, are lined up as if foran inspection, although the manner in which the children address the adults, in a mixture of broken English and their native languages, suggests at the same time an audition. When they are fi st asked to introduce themselves, they simply show their official tags, as if anticipating an 


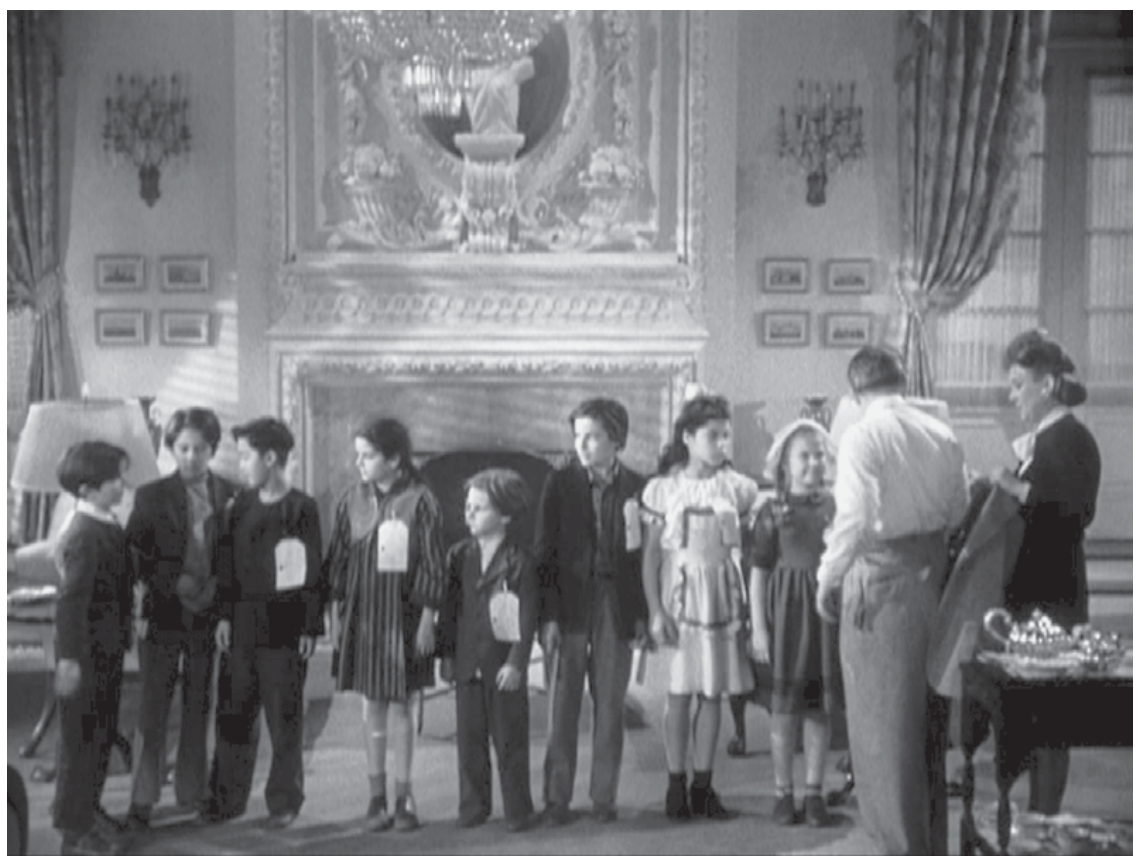

Figure 1.3 Heavenly Days

administrative bureaucratic regard. The McGees persist in talking to them one by one; as they move along the line of children, orchestral music plays on the soundtrack (as in Piper) and the film presents us with close-ups of the children's faces, approximating the McGees' perspective, as the children tell the McGees theirnames and nationalities: Katrina, a Dutch girl, Zoe, a Belgian girl, Pepi, a French boy, Jan, a Czechoslovakian boy, Dimita, a Greek girl, Yen Choi, a Chinese boy, Antonovich, a Russian boy and, lastly, Drinkwater, an English boy (figures 1.3 and 14). ${ }^{62}$

Unlike Holliday, in which Ruth provided information about each orphan's bereft and destitute state, Heavenly has the children speak, but onlyso as to off $r$ thanks to the McGees (or rather to the United States) for their kindness in receiving them. ${ }^{63}$ Theirexperiences of danger in the warzones are suggested by their scrambling for safety under sofasand tables when they mistake Fibber's whistle for an air raid alarm (the children in Holliday do something similar). But Heavenly arguably presents the children in a much more idealised register than either Piper or Holliday, and the effo ts of the child actors are emphasised by the formality and theatricality of the occasion the various orphans' faltering statements of thanks seem like rehearsed recitations, and when the Russian boy performs a Cossack dance, it is the young performer's accomplishments (more so than his character's predicament) the film exploits for sentimental eff ct. The director's initial screenplay specifi s one of the orphans as '[the] cutest youngster, perhaps a Czechoslovakian, an alert, curiousboy 


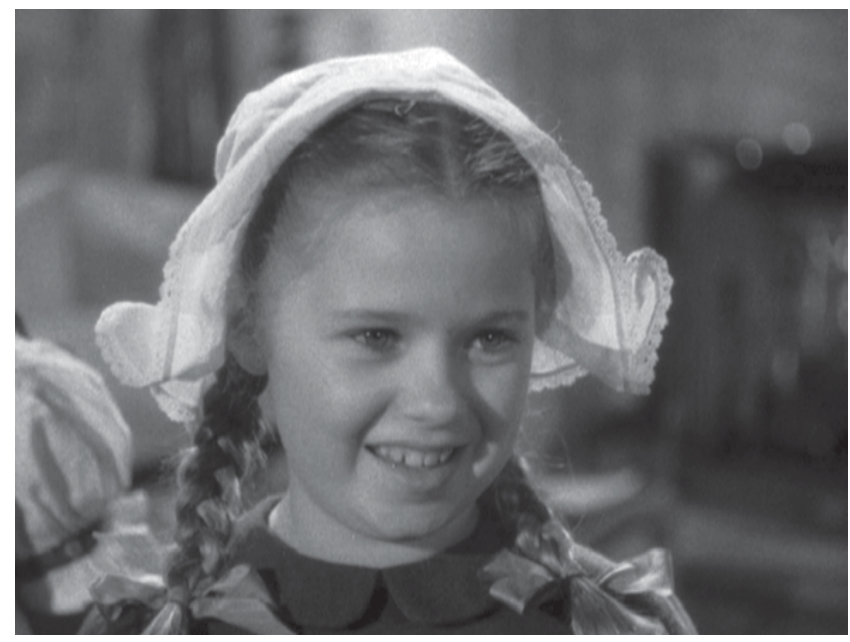

Figure 1.4 Heavenly Days

about fi e or six. ${ }^{64}$ In other words, the 'United Nations children' were from the outset conceived in terms of theirconventional aesthetic appeal (quantifiable cuteness) as much as their inernational diversity and specifi ity.

\section{The Boy with Green Hair}

According to Brian Neve (writing in 1992), Boy is a strange mixture of aesthetic experiment, social protest and studio sentiment. ${ }^{65}$ The film's protagonist, Peter, whose parents have died in the Blitz and whose hair has inexplicably turned bright green, encounters the group of war orphans following his involvement in his school's UNICEF-style charity drive. Earlier in the film, Peter looks at various humanitarian campaign posters in the school gymnasiumpromoting the Greek War Relief Association, the American Committee for Yugoslav Relief, the United Jewish Welfare Fund and United China Relief, as well as a poster showing an 'Unidentifi $d$ War Orphan'. After deciding to run away, he collapses in tears on the ground near a forest glade. A close-up of a tear sliding down a blade of grass, shotfrom Peter's point of view, places the audience in the protagonist's position. Peter hears another child call his name, and slowly stands up, at which point a match dissolve suggests the film enters his dream state or imagination. A shot of the forest glade shows a group of children, frozen in tableau; they are the children from the posters, wearing the same clothes and holding the same postures (see figures 1.5 and 16). For a few moments, as Peter approaches, they are motionless, and the film is silent, before some of them begin to walk toward and crowd around him, while melancholy orchestral music plays on the soundtack. The orphans explain that Peter must tell 'all the people' that 'war is very bad for children'; the 'Unidentifi $d$ War Orphan' refers specificaly 


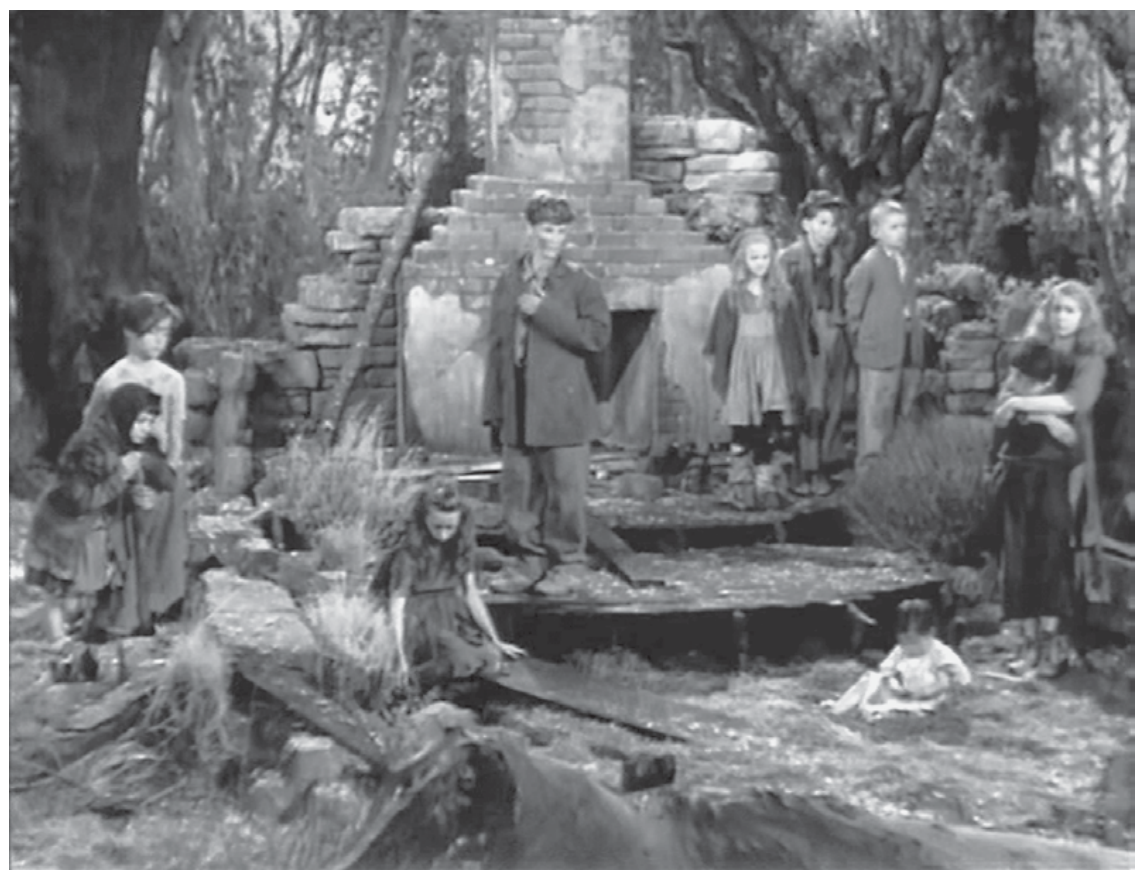

Figure 1.5 The Boy with Green Hair

to the original 'Four Policemen' of the UN, asking Peter to tell 'the Russians, the Americans, the Chinese, the British'. As the children take it in turns to talk to Peter, the film shifts between medium close-ups of the war orphans addressing Peter, close-ups of Peter listening and responding, and medium long-shots showing the orphans arrayed in the glade. Upon receiving his commission, Peter turns to face the camera (and the film's audience), and insists 'Theworlddoesn't have to be blown up'.

Whereas the earlier films presented groups of children journeying towards or recently arrived in the United States, Boy off rs instead children who remain distant others. While the fi st three films show children under the direct care of various guardians, as immediate responsibilities, Boy suggests the children are (still) in need of such care, and their needs remain mediated, fi st by the humanitarian campaign posters presented in the film, and second by the film itself. Thechildren in the posters at Peter's school reappear in the dream sequence, and the posters are thus revealed to be images of these juvenile actors posing as war orphans, and therefore as inauthentic and contrived as the glade sequence itself. Director Joseph Losey later admitted, 'the [original] story really was a fantasy about racial discrimination and that's what the picture shouldhave been about. But we all felt so strongly that there must be a world movement for peace that we tried to make a film about peace.66 Alerting audiences to the film's potentially problematic combining of topicalrealities 


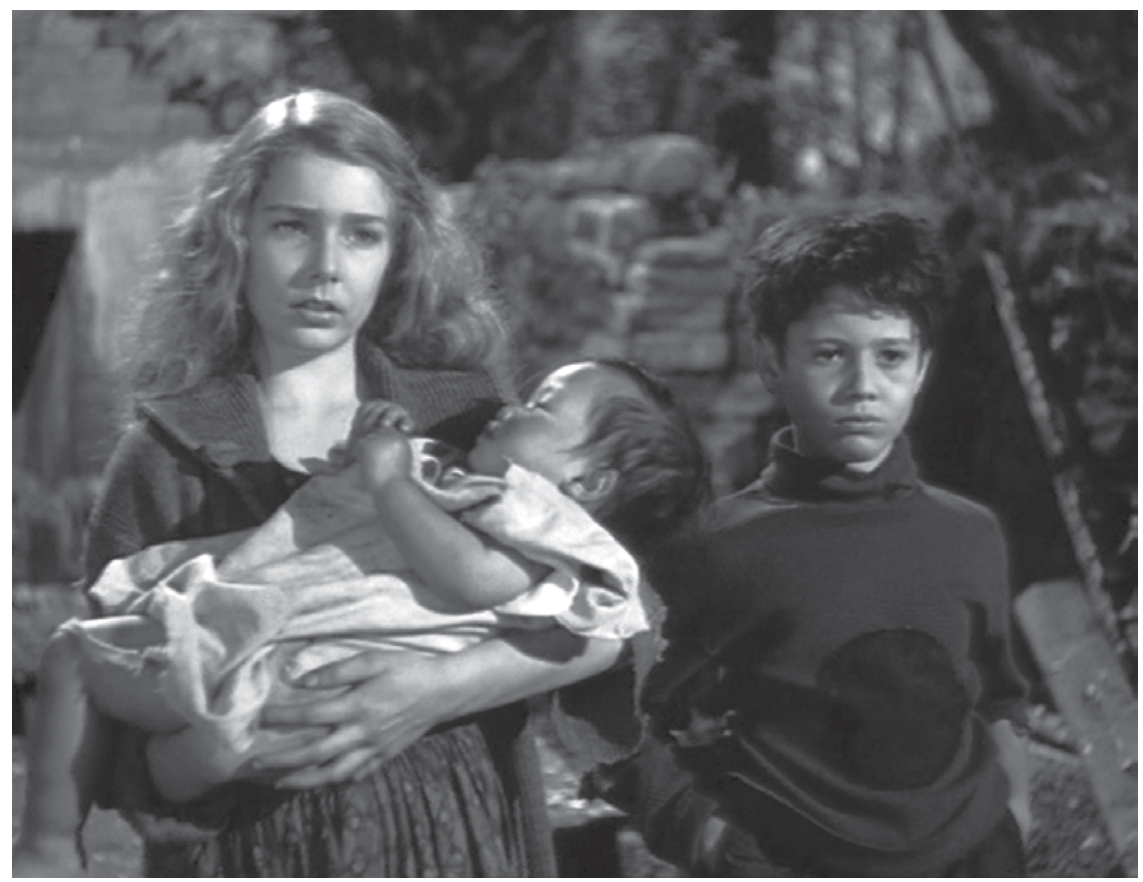

Figure 1.6 The Boy with Green Hair

and fanciful conceits, the RKO Press Book, whichdescribes Boy as 'a uniquedramatization of the plight suff red by children, innocent and unwilling victims of the wars that plague the world, acknowledges that 'the story fluctu tes between piquant imagery and realism. Refl cting on his attempts to combine elements of fantasy and reality in the film, Losey complained:

I was stymied in both because the reality was the RKO lot, their clapboard houses and their streets which had been used a million times before; it's pretty hard to get reality from that, so that was the problem ... Thetrouble with the fantasy was, nobody knew, nobody understood. What I wanted to get, in the scene in the glade, was absolute horror, real terror, the kind of thing Joris Ivens and John Ferno did in theirfilm of the Chinese-Japanese conflict, The Four Hundred Million [1939], with that shot of the baby sitting on the railway track, bombed and with no clothes, desolate and crying. I wanted to get that kind of horror, that kind of reality / [Th re's] no horror and there's no reality in the gdde, and the figures of the chidren are marionettes. ${ }^{67}$

Losey's frustration concerning his ambitions to replicate the 'kind of reality' he encountered in Ivens and Ferno's documentary withinhis film's fantastical premise is suggested by his likening the children to puppets. For Losey, the studio's commercial 
expediency thwarted his desire to experiment with the realism that a popular format might accommodate.

In a June 1943 address Frances Harmon, the Executive Vice-Chairman of the Motion Picture Industry divisionof the War Activities Committee, stated: 'Solidarity in the ranks of the United Nations is a prerequisite to victory in war and peace. Knowledge of one another and mutual appreciation of our diverse countries, cultures and war sacrifi es can be obtained most quickly on a popular level through this people's art which speaks a universal language. ${ }^{68}$ In a July 1943 speech Harmon celebrated the inspiring cooperation' of the filmindustry, which had 'proved conclusively that we can come together... as a hard-hitting team in behalf of victory for the United Nations' and then off red an intriguing analogy: 'Fundamental diff rences exist between some of the United Nations, but today all are united in a solemn determination to force the unconditional surrender of our common foes. Basic divergences similarly exist between various branches of our industry-between the artistic and the commercial approach to production problems. ${ }^{69}$ In both cases (the UN, the film industry) strength depends on unity, and quarrels will lead to weakness. The representation of children from the warzones in these Hollywood films is sometimes surprisingly realistic (for commercial entertainments) and sometimes objectionably sentimental (for topical dramas). The representation of these groups of children demonstrates how the 'divergence' between 'artistic' and 'commercial' approaches (not, or not always, however, synonymouswith realist and sentimental registers) is managed and modulated, sometimes in a single film. Thefour films' propaganda unquestionably derives from their presenting groups of children, but with varying degrees of realism and sentimentality - the genuine and the ate determining the authenticity and appeal of the children (including of course the children's performances themselves) and thus governing the apprehension of their suff ring. The groups of children in the fi st three films are assembled via increasingly bureaucratic modes of humanitarian action, from the ministrations of heroic individuals to the administration of international organisations: in Piper the children are under John's unofficial protection; in Holliday the children are originally from an institution (an orphanage) and must be processed by immgration services; in Heavenly the children have presumably come to America under the auspices of an official committee responsible for the adoption of war orphans. ${ }^{70}$ In Boy, however, the children appear fi st on photographs ( publicity materials for humanitarian campaigns) and subsequentlyin the protagonist's imagination. Theambiguousontological status of the children in this film - played by real children, they are presented fi st as 'documentary' images in the humanitarian campaign posters and then as 'imaginary' children in the protagonist's fantasy - is instructive for a consideration of the presentation of the children in the earlier films, precisely due to the awkward combination of realism and fantasy, and authenticity and sentimentality, with which the real suff ring of the war's youngest victims is presented as a 'sorrowful spectacle' both in the film and to the film's audience. 


\section{Notes}

1 The United Nations originated with the Declaration of the United Nations in January 1942, signed by the so-called Four Policemen (the US, the UK, the USSR and China) and a further twenty-two Allied Nations; the Organisation followed in 1945. The United Nations Relief and Rehabilitation Adminstration (UNRRA), established in 1943, and the United Nations International Children's Emergency Fund(UNICEF), established in 1946, represent the organisation's global humanitarian operations during and immediately following the war. Maurice Pate, UNICEF's fi st Executive Director, made his candidacy conditional on the organisation's committing to proide relief to children from the former Axis countries (see M. Black, The Children and the Nations: Growing Up Together in the Post-War World (Melboume: Macmillan, 1987), p. 17). The expansion of UNRRA's original remit reinforced the idea of the chid being 'before' or beyond the pditics of international relations.

2 L. H. Malkki, The Need to Help: The Domestic Arts of International Humanitarianism (Durham, NC and London: Duke University Press, 2015), p. 78.

3 Malkki, The Need to Help, p. 103; A. L. Stoler, 'Aff ctive States', in D. Nugent and J. Vincent (eds), A Companion to the Anthropology of Politics (Oxford: Blackwell, 2007), p. 9.

4 R. Williams, Marxism and Literature (Oxford and New York: Oxford University Press, 1977), p. 132.

5 J. Butler, Frames of War: When is Life Grievable? (London and New York: Verso, 2009), p. 1.

6 Butler, Frames of War, p. 5 .

7 Anon., 'Europe’s Children', New York Times (21 November 1943), p. 12, emphasis mine

8 Anon, 'Text of Lehman's Address in Accepting Directorship of United Nations Relief', New York Times (12 November 1943), p. 13, emphasis mine

9 L. Chouliaraki, The Spectatorship of Suffering (London, Thou and Oaks and New Delhi: Sage, 2006), p. 134.

10 T. Zahra, The Lost Children: Reconstructing Europe's Families after World War II (Cambridge, MA and London: Harvard University Press, 2011),p. ix.

11 D. Stephenson, 'UNRRA Will Help Children First When It Starts Vast Relief Job', New York Times (25 November 1943), p. 36.

12 D. Marshall, 'Humanitarian Sympathy for Children in Times of War and the History of Children's Rights, 1919-1959, in J. Marten (ed.), Children and War: A Historical Anthology (New York and London: New York University Press, 2002), p. 184.

13 W. L. Willkie, One World (New York: Pocket Books, 1943), p. 151

14 D. B. Jones, 'The Hollywood War Film: 1942-1944', Hollywood Quarterly, 1:1(1945), p. 1 In the 1940s awards were established for films 'promoting international understanding' (Golden Globe, from 1946) or 'embodying one or more of the principles of the United Nations Charter' (BAFTA [UK], from 049 ). War-themed films featuring children were often nomirated; Fred Zinneman's The Search (1948) for example, won both awards.

15 Jones, 'The Hollywood War Film', p. 8. The Government Information Manual for the Motion Picture Industry, published by the Office of War Information in 1942, off red producers and screenwriters specific instructions pertaining to the representation in films of the citizens and societies of the countries comprising the United Nations, with a particular focus on the Soviet Union and China, the countries about which the average American probably knew the least: for Koppes and Black, this manual strategically 'homogenized [the thirty member nations] into democratic societies which, whatever theirpeculiarities, shared a commonantifascist goal' (C. R. Koppes and G. D. Black, Hollywood Goes to War: How Politics, Profits and Propaganda Shaped World War II Movies (London: I. B. Tauris, 1987), p. 68). 
16 J. Wilson, 'Stardom, Sentimental Education, and the Shaping of Global Citizens', Cinema Journal, 53:2 (2014), p. 29.

17 Wilson, 'Stardom,Sentimental Education, and the Shaping of Global Citizens', p. 28, emphasis mine

18 C. Klein, Cold War Orientalism: Asia in the Middlebrow Imagination, 1945-1961 (Berkeley, Los Angeles and London: University of California Press, 2003), p. 14 In his discussion of the 'sentimental dramas' produced by Hollywood during the 1940s Chris Cagle notes that 'narrative scenarios wringing pathos by placing children in difficult situations are perhaps an ideal-type for cinematic hokum': 'the suff ring child' in such films, Cagle contends, is the 'lynchpin' connecting these dramas to 'wartime dislocation', but he is explicitly concerned with films that deal 'obliquely' rather than 'directly' with the war. See C. Cagle, 'The Sentimental Drama: Nostalgia, Historical Trauma and Spectatorship in 1940s Hollywood, Quarterly Review of Film and Video, 29 (2012), pp. 425, 426.

19 M. Todd Bennett, One World, Big Screen: Hollywood, The Allies, and World War II (Chapel Hill: The University of North Carolina Press, 2012), pp. 2-3, 5, 6.

20 Bennett, One World, Big Screen, p. 13. Thefourfilms discussed in this chapter are notmentioned in Bennett's book, nor are the more well-known films about Allied Nations' children such as MGM's Journey for Margaret (W. S. Van Dyke, 1942) or The Search.

21 L. Merish, 'Cuteness and Commodity Aesthetics: Tom Thumb and Shirley Temple', in R. Garland Tho son(ed.), Freakery: Cultural Spectacles of the Extraordinary Body (New Yorkand London: New York University Press, 1996), p. 187.

22 R. Patterson, 'TheUN in Hollywood: A Lesson in Public Relations', Hollywood Quarterly, 5:4 (1951), p. 329. Amongst the more widely seen documentaries concerning UNRRA's activities with displaced and orphaned children in Europe were Suffer Little Children (National Film Board of Canada, 1945), Seeds of Destiny (US War Department, 1946) and Passport to Nowhere (RKO Pathe, 1947).

23 Anon, 'UNRRA O ganises a Children's Fund, New York Times (17 August 1946), p. 2.

24 G. Samuels, 'The Unheard Cry of the Worlds Children', New York Times (12 October 1947), pp. 12,59 .

25 C. Bowles, 'To Bring Hope to Children WithoutHope', New York Times (1February 1948), p. 35

26 Anon, 'The ppeal for Children', New York Times (1 Feburary 1948), p. 10.

27 Malkki, The Need to Help, p. 86.

28 Butler, Frames of War, p. 1.

29 J. T. McManus, 'The Pied Piper', New York PM (13 August 1942), p. 22.

30 T. S., 'The Pied Piper', New York Times (13 August 1942), page unknown.

31 J. T. McManus, 'Fibber Goes A-Stumping', New York PM (22 October 1944), page unknown; Anon, 'Heavenly Days Brings McGees of Radio Fame to Palace Screen', New York Post (21 October 1944), page unknown.

32 B. Crowther, 'The Boy with Green Hair', New York Times (13 January 1949), page unknown.

33 H. Estabrook, 'Heavenly Days Shooting Script' (23 November 1943), pp 11, 26.

34 J. Chandler, The Archaeology of Sympathy: The Sentimental Mode in Literature and Cinema (Chicago and London: University of Chicago Press, 2013), pp 11-12, 13.

35 Chandler, The Archaeology of Sympathy, p. 17.

36 P. Sorlin, 'Children as War Victims in Postwar European Cinema', in J. Winter and E. Sivan (eds), War and Remembrance in the Twentieth Century (Cambridge and New York: Cambridge University Press, 1999), p. 12.

37 Sorlin, 'Children as War Victims', p. 13. 
38 C. Affron, Cinema and Sentiment (Chicago: University of Chicago Press, 1982), p. 4.

39 K. Schoonover, Brutal Vision: The Neorealist Body in Postwar Italian Cinema (Minneapolis and London: University of Minnesota Press, 2012), pp. xiv, xiii-xiv.

40 Schoonover, Brutal Vision, p. 151

41 War orphans and child refugees from Europe in fact appear in many popular feature films made in America during the war, and were arguably instrumental (even integral) to the anti-isolationist propaganda we associate with Hollywood productions such as Mrs Miniver (William Wyler, 1942). In MGM’s Journey for Margaret (W. S. Van Dyke, 1942), for example, Margaret O'Brien played an orphaned air raid victim at a London nursery adopted by an American joumalist, and in Fox's On the Sunny Side (Harold D. Schuster, 1942) Roddy McDowall played an English evacuee in Ohio 'for the duration. Following the end of the war, orphaned children from Europe continued to appear in generic and sentimental Hollywood entertainments: for example, the Czechoslovakian stowaway (Mark Dennis) in The Return of Rusty (William Castle, 1946), promoted with the tagline: 'A boy with a dog ... A kid without a country ... In a story with a great heart-tug!' and the boy of unknown nationality (Robert Blake) in The Return of Rin Tin Tin (Max Nosseck, 1947), the French girl (Beverly Simmons) smuggled into the United States in Buck Privates Come Home (Charles T. Barton, 1947) and the French orphans ( Jacques Gencel, Beverley Washbum) adopted by Bing Crosby in Here Comes the Groom (Frank Capra, 1951).

42 A. Bazin, 'Germany, Year Zero', in B. Cardullo (ed.), Bazin at Work: Major Essays and Reviews from the Forties and Fifties, trans. A. Piette and B. Cardullo (New Yorkand London: Routledge, 1997), p. 121.

43 Anon, 'Th ee Little ovie Girls', LIFE (26 February 1945), pp 7176.

44 A. Nemerov, Icons of Grief: Val Lewton's Home Front Pictures (Berkeley, Los Angeles and London: University of California Press, 2005), p. 51

45 T. S., 'The Pied Piper'.

46 A. Winsten, 'The Pied Piper', New York Post (13 August 1942), p. 34.

47 Anon, 'The Pied Piper', LIFE (10 August 1942), p. 47.

48 A. Cook, 'The Pied Piper', New York World-Telegram (13 August 1942), p. 8; T. S., 'The Pied Piper', page unknown; A. Winsten, 'The Pied Piper', p. 34.

49 See M. Lawrence, “"Bombed into Stardom!": Roddy McDowall, "British Evacuee Star" in Hollywood', Journal of British Cinema and Television, 12:1(2015), pp. 45-62; K. Cameron, 'Monty Wooley in a Gentle Role', Sunday News (9 August 1942), p. 71.

50 McManus, 'The Pied Piper', p. 22.

51 G. Agamben, Homo Sacer: Sovereign Power and Bare Life, trans. Daniel Heller-Roazen (Stanford: Stanford University Press, 1998).

52 Anon, 'The Pied Piper', New York Post (15 August 1942), page unknown.

53 In Shute's novel, however, it is the adult John who arranges with an aunt to look after Rose, decides to take Pierre with them after fin ing the boy beside his parents' bodies, and who assumes responsibility for the Dutch boy (called Willem in the film). See N. Shute, The Pied Piper (New York: Vintage, 2009), pp. 75, 97, 128.

54 John Boyne avers: ' $[i t]$ is particularly noteworthy, especially considering that this is a wartime novel published at the height of hostilities, that Shute recognizes no geographic boundaries or ideological diff rences in assembling his band of lost children'. 'The diff ring backgrounds of these children and, most crucially their ability to get along with each other during a stressful and exhausting journey, says much for Nevil Shute's ideals of human nature. At its most simple level he is asking the question why the adults of the world cannot coexist like these young 
innocents do.' See J. Boyne 'Introduction', in N. Shute, The Pied Piper (New York: Vintage, 2009), pp. xii, xiii.

55 W. K. Everson, 'Deanna Durbin and Jean Renoir', Films in Review, 37:8-9 (1986), p. 411, emphasis mine

56 E. A. Cunningham, 'The Amazing Mrs Holliday', Motion Picture Herald (6 February 1943), p. 1145.

57 T. S., 'The Amazing Mrs Holliday', New York Times (22 February 1943), page unknown.

58 Anon, 'China Girl', Monthly Film Bulletin, 10:111 (943), pp 27, 28.

59 Bennett, One World, Big Screen, p. 241.

60 McManus, 'Fibber Goes A-Stumping'; Anon, 'Heavenly Days', Variety (2 August 1944), page unknown.

61 Anon, 'Heavenly Days', Variety (2 August 1944), page unknown.

62 Two of the child actors in Heavenly had appeared in the earlier films; Teddy Infuhr, who plays Jan in Heavenly, played Teddy in Holliday, and Maurice Tauzin, who plays Pepi in Heavenly, played Pierre in Piper.

63 Lilie Chouliaraki suggests representations of gratitudein 'positive' humanitarian appeals (and specifica ly images of 'smiling children') work to 'unite donors in a community of virtue that discovers in its own fellow feeling for distant others a narcissistic self-involvement'. See The Ironic Spectator: Solidarity in the Age of Post-Humanitarianism (Cambridge: Polity, 2013), p. 63.

64 Estabrook, 'Heavenly Days Shooting Script' (23 October 1943), p. 11.

65 B. Neve, A Social Cinema: Film-Making and Politics in America (New York: Routledge, 1992), p. 100.

66 M. Ciment, Conversations with Losey (London: Methuen, 985), p. 86.

67 T. Milne (ed.), Losey on Losey (London: Secker \& Warburg/British Film Institute, 1967), pp. $68-9,70$.

68 F. S. Harmon, The Command is Forward: Selections from Addresses on the Motion Picture Industry in War and Peace (New York: Richard R. Smith, 944), pp. 25-6.

69 Harmon, The Command is Forward, p. 14.

70 For example, the United States Committee for the Care of European Children was responsible for coordinating the Directive on Displaced Persons which was aimed at filling immiration quotas with war orphans: sixty-seven such chidren arrived in the simmer of 1946.

\section{References}

Affron, C, Cinema and Sentiment (Chicago: University of Chicago Press, 1982).

Agamben, G., Homo Sacer: Sovereign Power and Bare Life, trans. Daniel Heller-Roazen (Stanford: Stanford University Press, 1998).

Anon, 'The Pied Piper', LIFE (10 August 1942), pp 47-50.

Anon., 'The Pied Piper', New York Post (15 Ayust 1942), page unknown.

Anon, 'China Girl', Monthly Film Bulletin, 10:111 ( 943$)$, pp 27-8.

Anon, 'Text of Lehman's Address in Accepting Directorship of United Nations Relief', New York Times (12 November 1943), p. 13.

Anon, 'Europe's Children', New York Times (21 November 1943), p. 12.

Anon, 'Heavenly Days', Variety (2 August 1944), page unknown.

Anon., 'Heavenly Days Brings McGees of Radio Fame to Palace Screen', New York Post (21October 1944), page unknown.

Anon, 'Th ee Little ovie Girls', LIFE (26 February 1945), pp 71-7. 
Anon, 'UNRRA O ganises a Children's Fund, New York Times (17 August 1946), p. 2.

Anon, 'The ppeal for Children', New York Times (1 February 1948), p. 10.

Bazin, André, 'Germany, Year Zero', in B. Cardullo (ed.), Bazin at Work: Major Essays and Reviews form the Forties and Fifties, trans. A. Piette and B. Cardullo (New Yorkand London: Routledge, 1997), pp 121-4.

Bennett, M. Todd, One World, Big Screen: Hollywood, The Allies, and World War II (Chapel Hill: The University of North Carolina Press, 2012).

Black, M., The Children and the Nations: Growing Up Together in the Post-War World (Melboume: Macmillan, 1987).

Bowles, C., 'To Bring Hope to Chidren Without Hope', New York Times (1 February 1948), pp. $10-11$, p. 35 .

Boyne, J., 'Introduction', in Nevil Shute, The Pied Piper (New York: Vintage, 2009), pp. vii-xv.

Butler, J., Frames of War: When is Life Grievable? (London and New York: Verso, 2009).

W., C. A., 'The Amazing Mrs Holliday', Today's Cinema (19 March 1943), p. 30.

Cagle, C., 'The Sentimental Drama: Nostalgia, Historical Trauma and Spectatorship in 1940s Hollywood', Quarterly Review of Film and Video, 29 (2012), pp 419-31.

Cameron, K, 'Monty Wooley in a Gentle Role', Sunday News (9 August 1942), p. 71.

Chandler, J., The Archaeology of Sympathy: The Sentimental Mode in Literature and Cinema (Chicago and London: University of Chicago Press, 2013).

Chouliaraki,L., The Spectatorship of Suffering (London,Thou andOaks andNewDelhi: Sage, 2006).

Chouliaraki, L., The Ironic Spectator: Solidarity in the Age of Post-Humanitarianism (Cambridge: Polity, 2013).

Ciment, M., Conversations with Losey (London: Methuen, 1985).

Cook, A., 'The Pied Piper', New York World-Telegram (13 August 1942), p. 8.

Crowther, B., 'The Boy with Green Hair', New York Times (13 January 1949), page unknown.

Cunningham, E A., 'The Amazing Mrs Holliday', Motion Picture Herald (6 February 1943), p 1145.

Everson, W. K., 'Deanna Dubin and Jean Renoir', Films in Review, 37:8-9 (1986), pp. 408-12.

Harmon,F. S., The Command is Forward: Selections from Addresses on the Motion Picture Industry in War and Peace (New York: Richard R. Smith, 1944).

Howard Estabrook Papers, Margaret Herrick Library, Academy of Motion Pictures Arts and Sciences.

Jones, D. B., 'The ollywood War Film: 1942-1944', Hollywood Quarterly, 1:1 (945), pp 1-19.

Klein, C., Cold War Orientalism: Asia in the Middlebrow Imagination, 1945-1961 (Berkeley, Los Angeles and London: University of California Press, 2003).

Koppes, C. R. and G. D. Black, Hollywood Goes to War: How Politics, Profits and Propaganda Shaped World War II Movies (London: I. B. Tauris, 1987).

Lawrence, M., “Bombed into Stardom!”: RoddyMcDowall, “British Evacuee Star" in Hollywood, Journal of British Cinema and Television, $\mathrm{D}: 1$ (2015), pp 45-62.

Malkki, L. H., The Need to Help: The Domestic Arts of International Humanitarianism (Durham, NC and London: Duke University Press, 2015).

Marshall, D., 'Humanitarian Sympathy for Children in Times of War and the History of Children's Rights, 1919-1959, in J. Marten (ed.), Children and War: A Historical Anthology (New York and London: New York University Press, 2002), pp. 184-99.

McManus, J. T., 'The Pied Piper', New York PM (13 August 1942), p. 22.

McManus, J. T., 'Fibber Goes A-Stumping', New York PM (22 October 1944), page unknown.

Merish,L., 'Cuteness and Commodity Aesthetics: Tom Thumband ShirleyTemple', in R. Garland Tho son (ed.), Freakery: Cultural Spectacles of the Extraordinary Body (New York and London: New York University Press, 1996), pp. 185-203. 
Milne, T. (ed.), Losey on Losey (London: Secker \& Warburg/ British Film Institute, 1967).

Nemerov, A., Icons of Grief: Val Lewton's Home Front Pictures (Berkeley, Los Angeles and London University of California Press, 2005).

Neve, B., A Social Cinema: Film-Making and Politics in America (New York: Routledge, 1992).

Patterson, R., 'The UN in Hollywood: A Lesson in Public Relations', Hollywood Quarterly, 5:4 (1951), pp 326-33.

S., T., 'The Pied Piper', New York Times (13 August 1942), page unknown.

S., T., 'The Amazing Mrs Holliday', New York Times (22 February 1943), page unknown.

Samuels, G., 'The Unheard Cry of the Worlds Children', New York Times (12 October 1947), pp. 12-13, 58-9.

Schoonover, K., Brutal Vision: The Neorealist Body in Postwar Italian Cinema (Minneapolis and London: University of Minnesota Press, 2012).

Shute, N., The Pied Piper (New York: Vintage, 2009).

Sorlin, P., 'Children as War Victims in Postwar European Cinema', in J. Winter and E. Sivan (eds), War and Remembrance in the Twentieth Century (Cambridge and New York: Cambridge University Press, 1999), pp. 104-24.

Stephenson, D., 'UNRRA Will Help Children First When It Starts Vast ReliefJob', New York Times (25 November 1943), p. 36.

Stoler, L. A., 'Aff ctive States', in D. Nugent and J. Vincent (eds), A Companion to the Anthropology of Politics (Oxford: Blackwell, 2007), pp. 4-20.

Williams, R., Marxism and Literature (Oxford and New York: Oxford University Press, 1977).

Willkie, W. L., One World (New York: Pocket Books, 1943).

Wilson, J., 'Stardom, Sentimental Education, and the Shaping of Global Citizens', Cinema Journal, 53:2 (2014), pp 27-49.

Winsten, A, 'The Pied Piper', New York Post (13 August 1942), p. 34.

Zahra, T., The Lost Children: Reconstructing Europe's Families after World War II (Cambridge, MA and London: Harvard University Press, 2011). 


\title{
Classical antiquity as humanitarian narrative: The Marshall Plan films about Greece
}

\author{
Katerina Loukopoulou
}

A growing number of studies have argued for a historical and historicised understanding of global humanitarianism and humanitarian intervention. ${ }^{1}$ However, the history of the interdependence of humanitarianism with media campaigns and the wider visual culture of each period remains an underexplored fi ld, as the few studies in this area highlight. ${ }^{2}$ TheMarshall Plan films stand for a landmark moment in the long history of this relationship; they were part of one of the fi st postSecond World War audio-visual campaigns to promote a humanitarian cause at a transnational level.

TheMarshall Plan (MP) is thewidelyused term to describe the European Recovery Program (ERP), that is the material aid that the United States sent to the devastated economies of Western Europe to help them with the reconstruction process after the Second World War. ${ }^{3}$ Overseen by the US State Department and the Department of Commerce, it was executed by a newly established agency, theEconomicCooperation Adminstration (ECA), which had offices in Washington and in each of the eighteen Western European countries that received the aid. It became known as the "Marshall Plan' after Secretary of State General George Marshall, who spearheaded its conception, impementation and pubicity campaigns from $\mathbf{9 4 7}$ onwards.

Having persuaded President Harry Truman of the need for the United States to boost European economies with immediate material aid, on 5 June 1947 General Marshall made the initial announement with a speech that was imbued with the rhetoric of impartial humanitarianism: 'our policy is not directed against any country or doctrine but against hunger, poverty, desperation, and chaos. Th s set the tone for the ensuing pro-MP campaigns to persuade the US taxpayers of the plan's worthiness and necessity. For example, on 17 November 1947 the newspaper of the US Congress of Industrial Organizations (CIO), a federation of industrial unions, featured pro-MP articles, in one of which the CIO president described the MP 'not merely as a gesture of humanitarianism'; 'hunger' was 'a threat to the peace and security of the world. The very use of the term 'humanitarianism' and 
its connection with geopolitics was thus very much in the air during this period of intense public debate about the parameters of the MP's implementation. The main area of disagreement withinUS political circles had to do with the MP moving away from the internationalist cooperation approach of previous relief schemes, such as that organised by the United Nations Relief and Rehabilitation Adminstration (UNRRA) (1943-7), towards adopting the mantra: 'The United States must run this show', as the Undersecretary of State for Economic Affai s put it in 1947. And, the 'Marshall Planners' ensured that 'this show' received more visibility and media presence both in the United States and in Europe than in previous cases of the United States off ring loans and aid that remained under theradar.

General Marshall's predilection for film was instrumental to this end, adopted as the ideal medium for propagating the 'benevolent' nature of the ERP. Marshall had expressed his staunch belief in the dramatic power of cinema to promote the US cause in 1942, when he personally hired renowned fic ion film director Frank Capra to work on the Why We Fight nonfic ion film series (1942-5). Marshall even publiclydefended his mobilisation of cinema at the Senate in response to accusations of trivialisation of the war effo t. ${ }^{5}$ While the Why We Fight series was produced for US audiences, the MP documentary films were commissioned exclusively for European ones, while a parallel and distinct pro-MP media campaign was running for the US public.

During a short period (1948-52), the MP-sponsored European Film Unit produced approximately 300 documentaries, newsreels and infomational films, alongsidepress releases, posters, photographs and exhibitions. ${ }^{6} \mathrm{MP}$ historian David Ellwood has recognised this as 'the greatest international propaganda and information programmeever seen in peacetime' and has claimed that 'the film program was at the heart of [the ERP] effo t'? Indeed, high expectations had been invested in the MP films, viewed at the time as the beginning of a 'European film movement." Tho gh funded by the United States, the European Film Unit had its headquarters in Paris and ensured that the films about the eighteen Western European countries that received the MP aid were directed by European filmmakers in multilingualversions intended for both national and transnational exhibition. Alongside documenting and reporting on the uses of the MP aid, these films were defin $\mathrm{d}$ by a humanitarian discourse that foregrounded what political scientist Michelle Cini has called 'the language of altruism.' Th s discourse was deemed necessary for att acting support for an aid programmewhose multi-layered economic,geopoliticaland military motivations and its subsequent impact have forlong been debated. As Cini has put it:

The humanitarian motive behind American involvement in the Marshall Plan is perhaps hardest to demonstrate ... The Marshall Plan's 'fl eced factor', which was important in ensuring the support of U.S. public opinionand Congress, was a necessary 
if not sufficient element in the promotion of a political consensus on Marshall Aid. It is not surprising, then, that the European Recovery Program shouldbe couched in the language of humanitarianism..$^{10}$

But in the case of the campaign for the persuasion of the European public, the mobilisation of the humanitarian discourse operated against a very diff rent geopolitical landscape. Scholarship tends to agree that the MP was a response to the pre-eminent fear of Truman's administration that communism would expand to Western Europe, accentuated by the prospect of a Communist electoral victory in Italy in 1948, and even more urgently with the ongoing Civil War in Greece, which had erupted very soon after the liberation of the country from the Nazis. TheGreek Civil War (1945-9) was fought between the Greek Government Army (backed by the United Kingdom and the United States) and the Democratic Army of Greece (backed by the USSR). ${ }^{11}$ The MP publicity campaign in Europe was thus addressing a much more divided public.

Scholarship on the MP films and the media campaign is a more recent addition to the long-standing discussion of the MP's impact and its history. The MP films re-emerged in the public sphere after almost half a century of neglect. Since the fi st screening of a selection at the 2004 Berlin Film Festival, public and scholarly interest in these films has expanded. Thanks to the Selling Democracy project and the expanding filmographic record, the MP films have att acted the interest of archivists and historians. ${ }^{12}$ With public events and digitisation projects, these films have found new audiences after almost sixty years in the United States, where they were banned from public viewings until 1990, because of a 1948 bill 'that prevented their being shown to American audiences (who were not to be "propagandized" with their own tax dollars)'. ${ }^{13}$ Although in Europe such a ban did not exist, they quickly fell into neglect. The Selling Democracy project has generated a process of unearthing the MP films in various European film archives, which is ongoing, especially in the case of the non-English versions and the trans-European ones.

The majority of writings about the MP's publicity campaign and the MP films tend to focus on national case studies, such as Ireland, Austria and Italy, and an emphasis on narratives of reconstruction, productivity and national identity. ${ }^{14} \mathrm{Th}$ case of Greece and the humanitarian narratives of the MP films at large have been underexplored so far. By concentrating on the MP films about Greece, my aim is to correlate their discourse of reconstruction with the narrative of humanitarianism and to complement my previouswork in this fi ld that explored the geopolitical and military contexts of the MP propaganda. ${ }^{15} \mathrm{Th}$ s is particularly relevant for the case of Greece, where the Civil War quickly acquired international dimensions, as had been the case with the Spanish Civil War in the 1930s. For Amikam Nachmani, historian of international relations, 'few if any twentieth-century civil wars involved greater 
foreign intervention than that in Greece. ${ }^{16}$ The country became the fi st 'hot spot' of the Cold War, with stark contradictions characterising this international intervention, the emphasis of which shifted from militarism to humanitarianism almost overnight. For example, in August 1949, the US Air Forces, with the collaboration of the Greek Government Army, dropped large amounts of napalm in the northern regions of Greece to wipe out the Democratic Army and to bring the civil war to an end. ${ }^{17}$ And in December 1949, the millionth ton of ERP aid arrived at the port of Piraeus and the Greek Army paraded it in central Athens with formal ceremonies. ${ }^{18}$ Until October 1949, when the Civil War ended, approximately 80 per cent of the MP aid to Greece had been channelled to support the Greek government's military operations against what Truman called the 'armed minonities' of the Democratic Army. ${ }^{19}$ The MP thus secured that Greece 'more than any other European country' retained 'its Western orientation by playing an integral role in the termination of the Civil War. ${ }^{20}$ Within this post-Civil War context, humanitarian aid became even more urgent in terms of relief and reconstruction, but even more crucially, in terms of implementing an ideology of humanitarian values that were aligned with the US foreign pdicy.

The majority of the MP films about Greece mobilise a particular kind of humanitarian narrative, one that evokes the ancient Greek heritage in such a way that it stands not only for Greece's reconstruction but also for Western Europe's future and its alignment with the US vision of a geopolitical 'pax Americana'. My argument is that the MP films inaugurated the visual politics of what historian of international affai s Michael Barnett has called 'the age of neo-humanitarianism', the period from the end of the Second World War up to the end of the Cold War. Ths period was characterised by a new 'architecture of humanitarianism', dominated at large by the patterns established by the United States during the Second World War, which were 'increasingly planning-minded and influ nced by states and their interests. ${ }^{21}$ It was withinsuch a context of 'mutualaid' and long-term planning that the target audiences in Western Europe experienced the MP films, often as part of the full MP package. As Sandra Schulberg has put it: the MP's 'genius lay not in sending moneybut in shipping tangible goods - fuel, fertilizer, food, farm animals, machinery - that were essential for life and for economicrecovery. ${ }^{22}$ Th se productsbore the ERP logo and the American flag, and their delivery was often accompanied by formal ceremonies and non theatrical screenings of MP films. While suchceremonial display framed the United States as provider of material goods, the rhetoric of the MP films sought to win over local audiences by engaging with the target country's history, while presenting the goods brought by the United States as essential to peacetime prosperity.

\section{The projection of ancient Greece onto post-Second World War neo-humanitarianism}

Notions of national cinemas and national historiography are inadequate methodologies to tackle the challenges of the complex network of production and exhibition 
and transnational narratives of the MP films. With on average ninediff rent language versions produced of each documentary and with an extensive network of theatrical and non theatrical distribution, the MP filmography must be one of the most expansive manifestations of 'the process of matching geo-political scale [with] language' and cultural heritage. ${ }^{23}$ Even if the funding originated from the United States, it was European filmmakers and production crews, deployed across the eighteen Western European recipient countries of MP aid, which produced the fi st purposeful cinematographic discourse of Europe for the Furopeans.

Thearrival of the MP films in Greece, where the experience of cinemagoing was rather limited, had a particular resonance in terms of showing Europe and Greece to the Greeks. Apart from newsreels, hardly any Greek documentaries about the country exist from before the mid-1950s, let alone documentaries about this crucial historical conjuncture, the immediate aftermath of the Civil War (1949-52). Up to the mid-1950s, Greek film production and exhibition were under huge fi ancial strain. ${ }^{24}$ Moreover, non fic ion cinema about Greece was sparse, mainlytaking the form of travelogues. ${ }^{25}$ TheMP films, therefore, can be considered amongst the fi st documentaries about modern Greece. If there is a commonthread in their narratives, it is the referencing of classicalantiquity as an anchorof transhistorical continuity between ancient and modern Greece, thus off ring a unifying rhetoric to the deep post-Civil War political and ideological divisions. Such is the case with the following MP films: Victory at Thermopylae (David Kurland, 1950); Marshall Plan at Work in Greece ( James Hill, 1950); The Corinth Canal (John Ferno, 1950); Island Odyssey (1950); A Doctor for Ardaknos (John Ferno, 1951); and The Good Life (Humphrey Jennings and Graham Wallace, 1951). While direct references to classical heritage are not prevalent in the other films about Greece - Return from the Valley (John Ferno, 1950); Mill Town (David Kurland, 1950); Story of Koula (Vittorio Gallo, 1951) - there is still a particular emphasis on history and the pastoral. $^{26}$

Due to Greece lacking both a tradition of and an infrastructure for documentary production at the time, the MP films about Greece were directed by nonGreek filmmakers from the ECA-sponsored units of London (The Good Life), Paris ( John Ferno's films) and Rome (Story of Koula). Th s was another facet of the 'Greek exception' (alongside it being the only post-Civil War European country to receive the $\mathrm{MP}$ aid), because most of the MP films about a specific country were directed by national filmmakers, sometimes building on the country's cinematographic and documentary tradition, as in the cases of Italy (neorealism) and the UK (the British Documentary Movement). Many MP films - such as the ones about Austria - mobilised national culture and identity politics in their audio-visual rhetoric. ${ }^{27}$ Although the MP films about Greece follow this trend, their projection of a 'humanitarian narrative' is consistently related to a historical dialectic between modern and classical Greece that positions the MP aid within a dual perspective of national reconstruction and universal necessity. 
The sociologist Nicos Mouzelis has discussed this attachment of modern Greece to its classical past as a form of cultural imperialism. For Mouzelis, this reappropriation of the ancient Greek heritage as a vehicle for the formation of modern Greek identity was a non-Greek invention, 'imported from abroad, as developed by the Europe of the Renaissance and the Enlightenment', creating thus what he calls a condition of 'disarticulation', a negative and artifi ial mapping of Greece's distant past onto its moden nation state. ${ }^{28}$ The MP $1 \mathrm{~ms}$ about Greece conform to this discourse, directly aiming to bridge the country's glorious past with the promise of an equallygloriousfuture that is more aligned with the US visionfor Western European unity as the stronghold to contain the expansion of communism. Th s is particularly prevalent in the films Corinth Canal, Victory at Thermopylae, Island Odyssey and this chapter's case study, The Good Life, initiated by renowned British documentarian Humphrey Jennings. My aim in what follows is to relate this process of 'disarticulation' with the way that The Good Life constructs its humanitarian narrative and audio-visual rhetoric.

To disentangle the complex geopolitical context within which this film was produced, I am drawing on what film historian Antoine de Baecque calls the 'cinematographic form of history'. Building on long-standing debates about positioning cinema in history, de Baecque argues that 'the historical operation-from archive to narrative - and the cinematographic process — through the aesthetic chain that transforms recorded material into a film ... produce a sensible experience of reality, past or present, by giving it form. Th s sets up historiography and cinema as two parallel phenomena, at once intellectual and aesthetic. ${ }^{29}$ The MP-sponsored cameras recorded material that filmmakers and editors shaped into the intellectual and aesthetic discourse of filmic historiography.

The notion of a 'cinematographic form of history' off rs a more nuanced understanding of the intense interaction of the documentary's filmic discourse with the reality it responds to than analytical models that tend to reduce culture to a supplement or mere ideological refl ction of hard politics. ${ }^{30}$ Cinema, as an intellectual and aesthetic enterprise, mobilises visual signifi rs to create an open-ended and fluidlanguage of historiography. In this light, it is worth foregrounding a statement by the Director of the American Historical Association, who in 1988 made a case to end the prohibition of the MP films in the United States by describing them as an important visual record of American foreign policy in action' (emphasis mine) ${ }^{31}$ It is not, therefore, a question of whether the filmmakers and producers of the MP films were consciouslyenacting a predetermined US foreign policy, but a question of how the films were off ring a parallel discourse about a reality being shaped by the impact of theERP.

Th s frameworkis particularlyapt for The Good Life, a documentary conceived and partly directed by Humphrey Jennings, an accomplished filmmaker with a central position in the influ ntial British Documentary Film Movement. By 1951, Jennings had forged one of the most sophisticated approaches to cinematographic'polysemy' 
and 'iconographic displacement' in the documentary film mode ${ }^{32}$ The Good Life shares a commonaesthetic trait with the majority of the MP films about Greece: the referencing of the country's ancient heritage, intertwined with the contemporaneous geopolitical landscape. But The Good Life stands out for its treatment of this trope in a similar way that Jennings's wartime propaganda films - Words for Battle (1941), Listen to Britain (1942) - occupy a distinct place for theirpoetic treatment of life at the British Home Front and for bringing to the fore 'the cultural plurality of the wartime totality. ${ }^{33}$ Similarly, Jennings brought a visual and intellectualsensibility to the mapping of classical antiquity onto Greece's post-war modernity and precarious state of affai s.

The Good Life was produced as part of the MP film series The Changing Face of Europe (1951), with each film focusing on one country and one theme (e.g. agriculture, health), butwithintheframeworkof European and internationalco-operation ${ }^{34}$ Apart from this commonthread, each film in the series has a distinctive approach ranging from the informational to the poetic. The Good Life seems to veer towards the latter and the fi al film might have been a fully poetic one, had it not been for Jennings's sudden death in Greece during the film's production. Although it is impos sible to determinewhichscenes were directed by Jennings himself, film scholar and Jennings biographer Kevin Jackson has claimed that the film bears Jennings's signature throughout: 'Few other directors would have chosen to begin and end their films with evocations of the Homeric world, or to film pastoral scenes of a shepherd boy with his pipes or his floc , let alonedoffthe hat to Lord Byron. ${ }^{35}$ Jennings would have been motivated by his romantic vision of Greece, as theland where Byron died, an interest that dated back to the late 1930s, as evidenced by his painting a cubist rendition of Byron dressed in characteristic early nineteenth-century clothes of Greek fighters of Independence, and his poem The Boyhood of Byron. ${ }^{36}$ Jackson has noted that during his travels in Greece, the director was carrying a copy of Edward Trelawny's Recollections of the Last Days of Shelley and Byron (1858). ${ }^{37}$ Alongside his philhellenism, Jennings's intellectual baggage played a key role in constructing the film's depiction of humanitarian intervention as simultaneously universal and circumstantial. ${ }^{38}$

Moreover, Jennings's assistant director, Graham Wallace, who completed the film, had already worked in the same capacity on previous Jennings films. One of these was The True Story of Lili Marlene (1944), a dramatised documentary aboutthe remarkable story of the song 'Lili Marlene' becoming a hit with soldiers from both sides of the war in Europe (Germans, English, Russians). Wallace was therefore well versed with the 'Jennings text', its carefully crafted dialogical sequences and 'intermedia linkages. ${ }^{39}$ Either because of this dualauthorshipor because of the wider neglect of the MP films, The Good Life was for long forgotten even amongst Jennings scholars, with extant prints held in the Imperial War Museum's Film Archive and in the US National Archives and Records Adminstration (NARA), until its recent digitisation and inclusion in BFs'comprehensive Jennings DVD collection (2013). 
Jennings's fi al film maintained the exploration of the pastoral-modernist dialectic prevalent in most of his films. ${ }^{40}$ According to film historian Philip Logan, The Good Life could be seen as a continuation of Jennings's previous Festival of Britain film Family Portrait (1951), which ends with a recognition of 'the Cold War climate and the international programme for political reconstruction of post-war Western Europe. ${ }^{41}$ Indeed, one of the concluding voiceover comments in Family Portrait depicts Britain as 'too small, too crowded to stand alone. We have to come both inside the family of Europe and the pattern overseas'. Th s duality is continued in The Good Life's commentary on Greece, a country that was heavily under an Anglo-American influ nce. And despite the film being sponsored by the US-funded European Film Unit, its perspective is informed by a British point of view with references to Byron's devotion to and death for the 'Greek cause' of independence. But this philhellenism had more recent roots in the UK, with Oxfam (Oxford FamineReliefCommittee) having been set up in 1942 in response to news of mass starvation in Nazi-occupied Greece. It was solely on Greece that Oxfam focused its charitable activities until the end of the war, before moving on to other territories and causes. ${ }^{42}$

Moreover, in the summer of 1944, the Fitzwilliam Museumin Cambridge opened an exhibition with the ambitious title 'Greek Art: 3000 B.C.-A.D. 1938.' Th s show was the result of political collaboration between the British and the Greek government in exile, with the motto 'everything good we stood for'. Greek art was hailed as the emblem of democracy and freedom in the fight against the Nazis. Historian Abigail Baker has analysed the propaganda value of this exhibition for both the British and the Greek governments, which resulted in a paradoxical 'celebration of Greek independence as dependent on foreign imperialism': 'Theidea of a debt owed to Greece for its cultural influ nce pervades the material relating to the exhibition. Even the poster used to advertise the exhibition credited ancient Greece with "all modern civilisation in Europe and America". ${ }^{33}$ Jennings would have taken note of this exhibition, considering the signific nt publicity and press coverage it received, and he had been a frequent visitor to the Fitzwilliam since his student days in Cambridge, often fin ing it a source of inspiration. ${ }^{44}$

The Good Life was only the second film that Jennings made with a non-British subject matter, the fi st being The Defeated People (1947) about post-war Germany. Jenning's films have in general been analysed withinthe history of the Documentary Film Movement, tightly associated with notions of Britishness. In a sense, this was inevitable, since its origins lay in powerful British institutions of the 1930s and 1940s, such as the Empire Marketing Board (EMB), the General Post Office (GPO), and the Crown Film Unit. However, after the Second World War key players of the Movement moved on to projects and positions associated with newly formed international organisations and 'universalist' ideologies. For example, John Grierson became UNESCO's Head of Communications (for a short spell), while Basil Wright andPaul Rotha directed and produced the UNESCO film World Without End (1953). 
In this context, Jennings's move to make a film that promoted the ERP can be seen as part of the British Documentary Movement's shift towards internationalism and global humanitarian causes. The Good Life documents aspects of the post-war reconstruction of the health system of Greece, as part of the wider European and international 'grand design' to eradicate disease through international collaboration. The film foregrounds images of children who become the fi st benefi iaries of the international humanitarian interventions and of the MP aid that helps Greece to build new and modern hospitals. Tho as Laqueur, historian of humanitarianism, off rs an apt description of nineteenth-century literary manifestations of the 'humanitarian narrative' as focusing 'on the personal body, not onlyas the locus of pain but also as the commonbondbetween those who suff $r$ and those who wouldhelp. ${ }^{45} \mathrm{Th}$ s kind of narrative has forged one of the central paradoxes of humanitarianism: the tension 'between emancipation and domination. ${ }^{46}$ Ths acquires powerful and dramatic connotations once transposed into a nonficion audio-visual discourse of factuality and direct address.

The MP films about Greece were produced after the end of the Civil War. Although some MP-sponsored reconstruction work had started in early 1948, when the Civil War wasin full fl wand the Greek film production in disarray, the ECA film unitsdid not arrive in Greece until late 1949. By then, there had notbeen signific nt visible progress in the reconstruction work to record. It is mainly in photographic records, rather than in the MP films, that researchers may find visual evidence of the actual construction of new buildings, bridges, hospitals and factories. ${ }^{47} \mathrm{Th} s$ thematic is therefore less prominent in The Good Life.

Instead, the camera focuses on 'bodies', on the actual recipients of humanitarian aid, and on what Laqueur calls 'the common bond' between givers and receivers of humanitarian aid: children inoculated against tuberculosis in the remote villages of Greece; patients recovering from illnesses; and orphan girls and boys at summer camps and orphanages supported by the MP aid. Moreover, the film's narrative situates the MP within the context of other recent and concurrent humanitarian interventions in Greece: the Red Cross's inoculation campaign against tuberculosis; United Nations International Children's Emergency Fund (UNICEF) posters, which feature in shots of children receiving the necessary nutrition; and the operations of the World Health Organization (WHO), which is shown crossing international borders and reaching the malaria-inflicted areas of mainland Greece, near Missolonghi where Byron died, as the film's voiceover reminds its viewers. It is only halfway through the film's narrative that the fi st direct mention of the MP aid occurs, in a shot of an ECA sign that both in Greek and English language acknowledges the source of funding for the new hospital shown in the background. Sequences of doctors treating patients with modern equipment are introduced with the voiceover remarking, 'Today, help is coming too, from America. Th s new sanatorium at Lamia in Greece was built as part of the European Recovery Programmé. 
Th s contextualisation of the MP aid was a reminder of how Greece had become the epicentre of expansive international humanitarian aid throughout the 1940s. UNRRA had, for example, off red the immediate emergency support towards the end of the war, while balancing 'political impartiality' with 'military exigencies. ${ }^{48}$ However, the MP's humanitarianism is not only promoted with reference to contemporaneous international organisations, but most crucially in relation to the universal principles of 'impartiality' and 'neutrality', which have historically 'rendered humanitarians apolitical (and that Marshall himself was keen to emphasise in his initial declarations of the Plan's purview). ${ }^{49}$ References to 'classical antiquity' achieve this: the film opens with a long panning shot of the ancient site of Delphi, 'the navel of the Earth' as mythically known, followed by a montage of closer shots of the surrounding ancient ruins and shots of young shepherds and theirfloc. Th s bucolic imagery off rs the visual cue for actor Leo Genn's carefully delivered voiceover to commence the film's opening commentary:

Whoever shall have taught me the at of healing, with himwill I share my substance. I will regard his offspring even asmy own brethren. I will impart the knowledge of healing by precept, by lecture, and by all other manner of teaching. So ran the cath taken by the physicians of Ancient Greece. The oot of al good life lies in good health. Ths they bdieved here on the slops of Mbunt Ida 2,00o years ago. 'Whatsoever house I enter', the Greek doctor solemnlyvowed, 'I will enter for the benefit of th sick.

Th se lines set the film's tone, with Genn's delivery maintaining a reassuring register throughout the film and particularly when the motto is repeated ('The root of all good life lies in good health'). But the viewer is quickly transferred to the urgency of the present with an abrupt cut from the bucolic landscape to a close up of a Chevrolet with the Red Cross sign speeding up across the bumpy roads of rural Greece to deliver anti-TB vaccination to remote villages. And Genn's 'voice-ofGod' narration sums up the introductory part with this line of transhistorical universalism: 'From Ancient Greece, this humane teaching spread across all Europe. Today, Europe returns her thanks to Greece inkind.'

The choice of Genn, renowned for his 'velvet' voice, to deliver the introductory commentary was well considered. An established actor by then, albeit largely in minorroles, his voice had accompanied a good number of nonficion British wartime propaganda films and he had also featured in Laurence Olivier's acclaimed fic ion propaganda Henry $V$ (1945). The choice of an actor for the voice-of-God narration also chimed with the British documentary's tradition of treating voiceover narration as a form of soundtrack with its own musicality and tonality ${ }^{50}$ Genn's professional and impassioned delivery accentuates the core theme of The Good Life, which is to balance the particularity of the Greek situation with the impartial and universal beliefs of ancient Greek physicians. 
If the opening narration and imagery stand for the universal humanitarian message, then what follows is the historical present. The Red Cross Chevrolet carrying the red sign 'International Tuberculosis Campaign' enters the village and the voiceover narration shifts to a point of view mode, as it is delivered in a female voice by one of the village's children: 'We could see that something important was going on and we children were all trying to find out what it was.' The Greek girls point-of-view accented narration introduces the viewer to the village's life and the positive reception of the Red Cross by the children who all turn up at the central square to be vaccinated. During the vaccination sequence, Genn's voice returns to repeat the opening lines 'Whoever shall have taught me the art of healing ....' The repetition off $r s$ a sense of rhetorical unity. Th s sound montage of the male professional voiceover narration with the young girls consolidates the dialectic of the 'universal with the circumstantial. Both sound and image carry the dialectic of the classical with the modern. The contrast between the assured male voiceover standing for the 'European-cum-British point of view' with the accented child's voice representing Greece could be interpreted as patronising, infantilising the Greeks as the ignorant natives who suff $r$ from diseases that the more civilised Europeans will eradicate. The line 'Europe returns her thanks to Greece in kind' is an instance of what Mouzelis calls 'disarticulation': the ancient Greek heritage returns to Greece via a foreign voice that possesses the knowledge of millennia and brings it back to its homeland. ${ }^{51}$ Similarly, in his innovative study The Nation and its Ruins, Yannis Hamilakis has demonstrated how classical antiquity stood for Greece's alliance with the West and the so-called 'free world' during and after the Civil War. ${ }^{52}$

Thechild's point of view, though, could also be seen as representing the future of the country. As FrankMehring has noted in his comparative study of MP films, children and young people were an att active and popular theme, featuring prominently in many MP films to project the future of Europe. ${ }^{53}$ The Good Life, however, is not obliviousto the predicaments of the Greek orphans, victims of the vicious Civil War. In an ironicand rhetorically self-consciousmode, the film's narrative appears to turn against its own discourse and to question the relevance of the ancient Greek classical heritage with a shot of a boy labouring as a shoe polisher with the Parthenon in the background (see figure 2.1). Ths shot is the 'climax' of a sequence, introduced with discomforting questions that implicate the viewer:

all across our ancient continent, we Europeans dwell surrounded by much of the greatest that life can off $r$, fashioned by our forebears, bequeathed to us and our children. Have we nothing to hand on but this? [a shot of run-down dwellings] ... Will those who follow say we left them this? [a shot of children playing and sorting out rubble from damaged buildings] ... those without inheritance, selling peanuts, shining shoes beneath the glories of our commonpast [a shot of a boy polishing shoes at the foot of Acopolis]. 


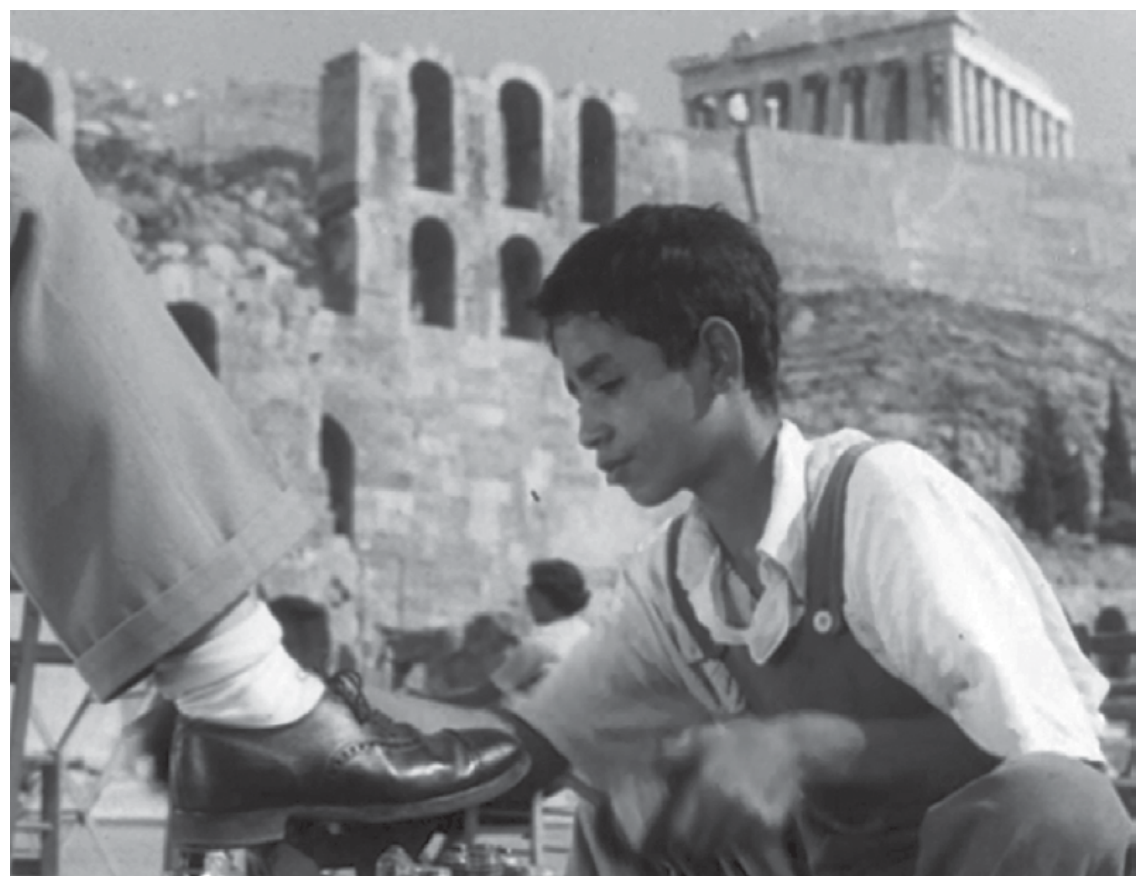

Figure 2.1 The Good Life. The light of imporished children in Greece, as framed against the weight of the ountry's heritage and the dhumanised leg of the present, a synecdoche for the indff rent wealthy

If there is one sequence with Jennings's signature throughout, then this should be a strong candidate: it bears the director's predilection for treating landscape as a foundobject to comment critically on the current state of a nation. In Spare Time (1939), for example, Jennings had famouslyframed the statue of Richard Cobden, manufacturer and advocate of a free-trade liberal capitalist ideology, against the grim and desolate landscape of factory chimneys ${ }^{54}$ Similarly, in The Good Life, the revered pictorial motif of the Acropolis is subverted by the very presence of theimpoverished child; the framing throws into question the contradictory meanings of what classical antiquity could stand for withinthe context of the earlystages of the Cold War: as an apolitical cultural terrain, potent enough to conjure up sentiments of national and trans-European unity; and as what Alexander Kazamias has called 'a Greek version of anti-communism' exploited by the royalist, right-wing government to promote a new discourse of 'national mindedness (ethnikofrosyni)' ${ }^{55} \mathrm{Th}$ s shot subverts both discourses through the sheer powerful juxtaposition of the new (a child in a state of exploitation and precarious existence) and the old (the celebrated Parthenon, standing as an impassive reminder of how history can too often be indiff rent to its 'lesser' characters). The positioning of the child in the frame creates a sense of 
entrapment - caught hopelessly, both between the indiff rent foot of the well-off customer and the architecture of the powerful past, and between the materials of modernity and thepast.

A similar vein of cautiousness can be detected in the film's concluding sequences, whichin a way share similarities with Jennings's A Diary for Timothy (1946), in which the director had warned against the dangers of complacancy and triumphalism in postwar Britain. The village girls accented voiceover retums to introduce one of the film's last sequences, in which three teenage girls are shown sewing in a cheerful mood. But the voiceover reminds the viewer that their reality is harshly diff rent: 'Koula has no parents, they were shot outsideher home; Parisiand Maria have never been to school. A shell hit it.' Th s is followed by a long shot of teenage girls exercising outsidea brand new school and here the girl's voiceover directlyinterpellates the adultviewer: 'Perhaps your children do this at school every day ... But don't forget that millions of us haven't had time to think about keeping clean or being well since I was born.' Th film concludes with visual rhymes: a montage of shots of the famouswall paintings of the Minoan women dancers of Knossos Palace intercut with shots of modern Greek teenage girls dancing along a traditional folksong (see figure 2.2). A sense of empowerment is conveyed as the modern young Greek women are compared with the ones of the Minoan society, where women occupied privileged, visible positions.

TheKnossos sequence leads to a succession of shots of Delphi, the Acropolis and the Parthenon, followed by shots of modern hospitals and an expansive bridge in an unnamed Northern European country, with the voiceover narration delivering the concluding unifying message: 'In the Europe of today, we are striving towards a better life for all our people, young and old, striving to blend the best of our past with the best that the present can off $r$, building as it were a grand design for the future of our continent. Let us be sure it rests upon that fi m foundation: the harmony of the human mindand body in full health' Th s sequence and the voiceover re-affirm the film's audio-visual rhetoric, which strives to establish the ERP as part of
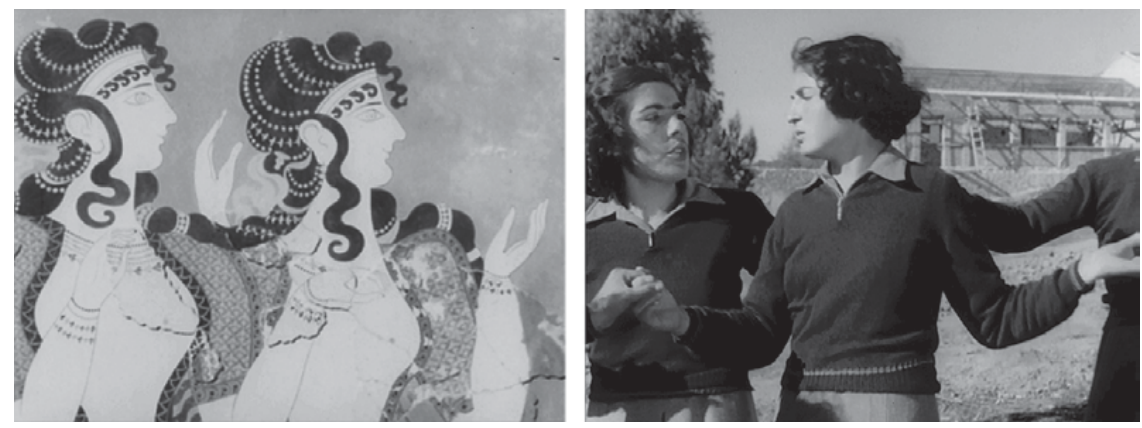

Figure 2.2 The Good Life. Montage sequence that sets the young orphans of the Greek Civil War in dalogue with their áncestors' 
a universal humanitarian order. It does so by appropriating the ancient Greek heritage as the ERP's forbear. And this results in shaping the narrative of the US aid as a benevolent force that helps Western Europe to overcome its dviding recent past.

\section{Conclusion}

The Good Life is heavily implicated with the US-led 'neo-humanitarian' discourse of the post-Second World War era. But the director's agency for a poetic cinematographic discourse lends the film a humanitarian narrative that veers towards romanticism with its focus on children - 'the living spirit of today', as the voiceover narration emphatically reminds the viewers. Logan has drawn an interesting parallelism in relation to Jennings's being caught in the maelstrom of the geopolitical forces of the time: 'International politics had contributed to Byron's accidental death while in Greece and so it was for Jennings ... as in his other films, through cultural and social references and its implicit political commentary, The Good Life would have provided both witting and unwitting testimony to a greater international story. ${ }^{56}$ Th s 'international story', however, needs qualifying. If Byron stood for one of the earliest cases of humanitarianism and humanism that permeated the early nineteenth-century philhellenic movement and its concomitant rebellion against the Ottoman Empire, then Jennings's film was implicated in a matrix of geopolitical forces, where the humanitarian cause was implicated with the US foreign policy to contain the Soviet Union away from the Mediterranean and Western Europe.

Jennings's and Wallace's creative choices chime with the wider ideological construct of the time that linked the notions of universalism and internationalism with Greece, a country that in post-Enlightenment Europe stood for the source of such aspirations. For example, UNESCO, upon its establishment in 1945, had adopted a minimalist rendition of the Parthenon as its visual logo, manifesting thus the endorsement of a Eurocentric iconography. Often with a critical undertone, the filmmakers structured The Good Life around relationships and contrasts between the Greek classical heritage and the post-Civil War present. The humanitarian aid that the MP brings to Greece is very diff rent from the one of urgent relief from starvation that Oxfam had off red during wartime. Thehumanitarian intervention, as represented in the MP films, and in particular in The Good Life, has more to do with reasserting the newly re-invented universal values of humanism, impartiality and individualism. Whenever the film's motto is repeated ('The source of good life lies in good health') it is visually associated with the individualbodies of young men and women and with international organisations aligned with the hest (the likes of Geneva, Italy, Austria and the United States). The more apolitical the discourse is, the more powerful the humanitarian narrative becomes.

The invocations of the classical past are infl cted by the US liberal humanist ideology of the time, which projected a teleological line of continuity from the dictum of impartiality, as advocated by the ancient Greek physicians, to the 
American promise of a 'free world. The vehicles for this narrative are the bodies of the children and the young people who are inoculated and provided with welfare, through a process of building a new Europe of liberal ideology and Western-centred civilisation, and by the exclusionof all the other Eastern European countries that Cold War politics had excluded from the MPs reach. ${ }^{57}$

\section{Notes}

1 See M. Barnett, Empire of Humanity: A History of Humanitarianism (Ithaca: Cornell University Press, 2011); B. Simms and D. Trim (eds), Humanitarian Intervention: A History (Cambridge: Cambridge University Press, 2011).

2 K. Rozario, "'Delicious Horrors”: Mass Culture, the Red Cross, and the Appeal of Modern American Humanitarianism', American Quarterly, 55:3 (2003), p. 417-55; M. Hilton, 'Ken Loach and the Save the Children Film: Humanitarianism, Imperialism, and the Changing Role of Charity in Postwar Britain, The Journal of Modern History, 87:2 (2015), pp 35-94.

3 Th oughoutthe chapter, I use both abbreviations (ERP and MP) as synonyms to refer to the European Recovery Program and the Mrshall Plan respectively.

4 The source of all quotations in this paragraph is G. M. Fujii, 'Selling the Marshall Plan in the United States', in G. Bischof and D. Stiefel (eds), Images of the Marshall Plan in Europe (Innsbruck: StudienVerlag, 2009), pp. 40-1.

5 R. D. MacCann, The People's Films: A Political History of US Government Motion Pictures (New York: Hastings House Publishers, 1973), p 156.

6 A. Hemsing, 'The Marshall Plan's European Film Unit, 1948-55: A Memoir and Filmography', Historical Journal of Film, Radio and Television, 14:3 (\$94), pp. 269-97.

7 D. W. Ellwood, “'You Too Can be Like Us”: Selling the Marshall Plan', History Today (October 1998), p. 33; D. W. Ellwood, 'Film and the Marshall Plan', in G. Bischof and D. Stiefel (eds), Images of the Marshall Plan in Europe (Innsbruck: StudienVerlag, 2009), p. 61.

8 A. Knight, 'Documentary - Rallying Point forEurope', Saturday Review (17 February 1951),p. 42.

9 M.Cini, 'From the Marshall Plan to EEC: Direct and Indirect Influ nces', in M. Schain(ed.), The Marshall Plan: Fifty Years After (New York and Basingstoke: Palgrave Macmillan, 2001), p. 16.

10 Cini, 'From the Marshall Plan to EEC', p. 16.

11 H. Jones, A New Kind of War: America's Global Strategy and the Truman Doctrine in Greece (New York: Oxford University Press, 1997); R. J. McMahon, The Cold War: A Very Short Introduction (Oxford: Oxford University Press, 2003), pp 27-8.

12 S. Schulberg, Selling Democracy: Films of the Marshall Plan, 1948-53 (New York: Schulberg Productions, 4th edn, 2008); L. Christenson, Marshall Plan Filmography, www.marshallfilms. org. Accessed 20 July 2016.

13 S. Schulberg, 'Selling Democracy Worldwide', www.sellingdemocracy.org/worldwide.html. Accessed 20 July 2016.

14 B. Whelan, 'Marshall Plan Publicity and Propaganda in Italy and Ireland, 1947-1951', Historical Journal of Film, Radio and Television, 23:4 (2003), pp. 311-28; G. Bischof and D. Stiefel (eds), Images of the Marshall Plan in Europe: Films, Photographs, Exhibits, Posters (Innsbruck: StudienVerlag, 2009); R. Longo, 'Between Documentary and Neorealism: Marshall Plan Films in Italy (19481955)', California Italian Studies, 3:2 (2012), http:// escholarship.org/uc/item/0dq0394d. Accessed 10 Feburary 2015. The fi st book-length study that examines the MP films from a transnational perspective is the recent publication by Maria Fritsche, The American Marshall Plan Film Campaign and the Europeans: A Captivated Audience? (London Bloomsbury, 2018). 
15 K. Loukopoulou “'A Campaign of Truth”: Marshall Plan Films in Greece', in Wasson and Grieveson (eds), Cinema's Military Industrial Complex (Oakland, CA: University of California Press, 2018), pp. 321-37.

16 A. Nachmani, International Intervention in the Greek Civil War: The United Nations Special Committee on the Balkans, 1947-52 (New York: Praeger, 1990), p. 3.

17 Jones, A New Kind of War, pp. 217-18.

18 A photograph of this parade is available at the online archive of the George C. Marshall Foundation, http:// marshallfoundation.org/library/ photographs/ millionth-ton-of-margcm00174. Accessed 10 May 2015.

19 S. Zachariou, 'The Dichotomy of Projecting the Marshall Plan in Greece: The Ideological Battlevs. the Rehabilitation Effo t', in Bischofand Stiefel, Images of the Marshall Plan in Europe, p. 108.

20 S. Zachariou, 'Struggle for Survival: American Aid and Greek Reconstruction', in M. Schain (ed.), The Marshall Plan: Fifty Years After (New York and Basingstoke: Palgrave Macmillan, 2001), p 160.

21 Barnett, Empire of Humanity, pp. 7, 108.

22 Schulberg, Selling Democracy, p. 10.

23 N. Durovičová, 'Vector, Flow, Zone: Towards a History of Cinematic Translatio', in N. Ďurovičová and K. Newman (eds), World Cinema, Transnational Perspectives (New York and London: Routledge, 2009), p. 98.

24 V. Karalis, A History of Greek Cinema (New York: Continuum, D12), pp 44-50.

25 A. Pagoulatos and N. Stabakis, 'Greece', in I. Aitken (ed.), The Concise Routledge Encyclopedia of the Documentary Film (New York: Routledge, 2013), pp 324-33.

26 The main source for identifying these MP documentary films about Greece is the Marshall Plan Filmography, www.marshallfilms.org/mpfasp. Accessed 25 March 2015. No director is credited for Island Odyssey: the only existing infomation is that it was produced by the ECA Paris for the ECA Greece. Viewing copies for all nine documentaries about Greece are available in English at the US National Archives and Records Adminstration (NARA) and information about them is included in the aforementioned MP Filmography website. Ths is a comprehensive list as per the following critieria: viewing copies available; confi med MP sponsorship; documentary mode of production. However, it is possible that more MP films about Greece and other European countries could be identifi d in the future. No copies have been located so far in Greek or with Greek subtitles. Digital files of a selection of MP films (including a few about Greece) in German and French can be viewed at the following online collections: Deutsche Historische Museum (DHM), www.dhm.de/filmarchiv/die-filme; Institut National de PAudiovisuel (INA), www.ina.fr. Accessed 20 July 2016.

27 R. Reichert, 'Culture and Identity Politics: Narrative Strategies in Austrian Marshall Plan Films', in Bischof and Stiefel, Images of the Marshall Plan in Europe, pp. 129-38.

28 N. Mouzelis, Modern Greece: Facets of Underdevelopment (London: The Macmillan Press, 1978), p. 145.

29 A. de Baecque, Camera Historica: The Century in Cinema, trans. N. Vinsonneau and J. Magidoff (New York: Columbia University Press, 2012), p. 19.

30 The work of Guilbaut and Saunders is pioneering in terms of foregrounding the ideological uses of cultural diplomacy during the Cold War; but their methodological approach for analysing the relationship between culture and US foreign policy is reductive, with little consideration of aesthetic choices and the agency of the artists. See S. Guilbaut, How New York Stole the Idea of Modern Art: Abstract Expressionism, Freedom and the Cold War (Chicago: University 
of Chicago Press, 1983) and F. S. Saunders, Who Paid the Piper? The CIA and the Cultural Cold War (London: Granta Books, 1999).

31 Letter (20 April 1988) from Samuel Gammon, the Executive Director of the American Historical Association, sent to Senator John Kerry, supporting the introduction of legislation that would eventually lift the prohibition against domestic screenings of the Marshall films, quoted in Hemsing, 'The arshall Plan's European Film Unit', p. 276.

32 D. Mellor, 'Sketch for an Historical Portrait of Humphrey Jennings', in M. L. Jennings (ed.), Humphrey Jennings: Film-Maker, Painter, Poet (London British Film Institute/ Palgrave Macmillan, 2nd eln, 2014), pp 106, 121.

33 Mellor, 'Sketch', p. 117.

34 See www.marshallfilms.org/filminfoasp?id=GL-5\&enlarge=False. For further information about the series The Changing Face of Europe, see the DHM entry www.dhm.de/filmarchiv/ die-filme/changing-face-of-europe. Accessed 20 July 2016.

35 K. Jackson, 'The Good Life', The Complete Humphrey Jennings, Vol. 3, DVD Booklet (London: British Film Institute, 2013), p. 27.

36 Mellor, 'Sketch', pp. 107, 111.

37 Jackson, 'The Good Life', p. 26.

38 Barnett, Empire of Humanity, p. 11

39 Mellor, 'Sketch', p. 106.

40 P. Logan, Humphrey Jennings and British Documentary Film: A Reassessment (Farnham: Ashgate, 2011), p 338 ; Jackson, 'The Good Life', p. 27.

41 Logan, Humphrey Jennings, p. 337.

42 Barnett, Empire of Humanity, p. 17.

43 A. Baker, “"Everything good we stood for”: Exhibiting Greek Art in World War II', Classical Receptions Journal, 8:3 (2016), pp. 414-15.

44 Mellor, 'Sketch', p. 106.

45 T. Laqueur, 'Bodies, Details, and the Humanitarian Narrative', in Lynn Hunt (ed.), The New Cultural History (Berkeley, Los Angeles and London: University of California Press, 1989), p. 177.

46 Barnett, Empire of Humanity, p. 11 .

47 A photographic collection of the MP in Greece is held at TheHistorical Archives of the Piraeus Bank Group Cultural Foundation, Athens, www.piop.gr/en/istoriko-arxeioaspx. Accessed 20 July 2016.

48 F. Tsilaga, 'UNRRA's Relief Effo ts in Late 1944 Greece: Political Impartiality versus Military Exigencies', in R. Clogg (ed.), Bearing Gifts to Greeks: Humanitarian Aid to Greece in the $1940 \mathrm{~s}$ (New York: Palgrave Macmillan, 2008), pp. 189-211.

49 Barnett, Empire of Humanity, p. 2.

50 M. Stollery, 'The Newsreel Commentator, the Actor, the Intellectual, and the Broadcaster: Celebrity and Personality Voices in Classic British Documentary', Celebrity Studies, 4:2 (2013), pp. 202-18.

51 Mouzelis, Modern Greece, p. 145.

52 Y. Hamilakis, The Nation and its Ruins: Antiquity, Archaeology, and National Imagination in Greece (Oxford: Oxford University Press, 2007).

53 F. Mehring, 'The Promises of "Young Europe": Cultural Diplomacy, Cosmopolitanism, and Youth Culture in the Films of the Marshall Plan', European Journal of American Studies, 7:2, Document 11 (2012), pp. 1-28, http:// ejas.revues.org/9701. Accessed 10 April 2016.

54 Mellor, 'Sketch', p. 116. 
55 A. Kazamias, 'Antiquity as Cold War Propaganda: The Political Uses of the Classical Past in Post-Civil War Greece', in D. Tziovas (ed.), Re-imagining the Past: Antiquity and Modern Greek Culture (Oxford: Oxford University Press, 2014), p 128.

56 Logan, Humphrey Jennings, p. 338

57 Research for this chapter was funded by the Action 'Supporting Postdoctoral Researchers', supported by the European Union's National Strategic Research Framework (NSRF, 20072013 www.espa.gr/en), adminstered in Greece by the Secretariat of Research and Technology (www.gsrt.gr) and by the Research Office (ELKE) of Panteion University that hosted the Fellowship. For advice and support, I thank the project's Scientific Advisor at Panteion, Dr Yannis Skarpelos. For help with the archival research, viewing MP films and contextual information, I thank: Linda R. Christenson, the MP filmographer, and the staff at: the Imperial War Museum Film Archive, London; the EYE Film Archives, Amsterdam; and the Historical Archives of the Rraeus Bank Group Cultural Foundation, Athens.

\section{References}

Baker, A., ' "Everything good we stood for": Exhibiting Greek Art in World War II', Classical Receptions Journal, 8:3 (2016), pp. 404-28.

Barnett, M., Empire of Humanity: A History of Humanitarianism (Ithaca: Cornell University Press, 2011).

Bischof, G. and D. Stiefel (eds), Images of the Marshall Plan in Europe: Films, Photographs, Exhibits, Posters (Innsbruck: StudienVerlag, 2009).

Christenson, L, Marshall Plan Filmography, www.marshallfilms.org. Accessed 20 July 2016.

Cini, M., 'From the Marshall Plan to EEC: Direct and Indirect Influ nces', in M. Schain (ed.), The Marshall Plan: Fifty Years After (New York and Basingstoke: Palgrave Macmillan, 2001), pp. 13-37.

de Baecque, A., Camera Historica: The Century in Cinema, trans. N. Vinsonneau and J. Magidoff (New York: Columbia University Press, 2012).

Durovičová, N., 'Vector, Flow, Zone: Towards a History of Cinematic Translatio', in N. Durovičová and K. Newman (eds), World Cinema, Transnational Perspectives (New Yorkand London: Routledge, 2009), pp. 90-120.

Ellwood, D. W., “'You Too Can be Like Us”: Selling the Marshall Plan', History Today (October 1998), pp. 33-9.

Ellwood, D. W., 'Film and the Marshall Plan', in G. Bischof and D. Stiefel (eds), Images of the Marshall Plan in Europe (Innsbruck: StudienVerlag, 2009), pp. 61-8.

Fujii, G. M., 'Selling the Marshall Plan in the United States', in G. Bischof and D. Stiefel (eds), Images of the Marshall Plan in Europe (Innsbruck: StudienVerlag, 2009), pp. 39-57.

Guilbaut, S., How New York Stole the Idea of Modern Art: Abstract Expressionism, Freedom and the Cold War (Chicago: University of Chicago Press, 1983).

Hamilakis, Y., The Nation and its Ruins: Antiquity, Archaeology, and National Imagination in Greece (Oxford: Oxford University Press, 2007).

Hemsing, A., 'The Marshall Plan's European Film Unit, 1948-55: A Memoir and Filmography', Historical Journal of Film, Radio and Television, 14:3 (994), pp. 269-97.

Hilton, M., 'Ken Loach and the Save the Children Film: Humanitarianism, Imperialism, and the Changing Role of Charity in Postwar Britain, The Journal of Modern History, 87:2 (2015), pp. 357-94. 
Jackson, K., 'The Good Life', The Complete Humphrey Jennings, Vol. 3, DVD Booklet (London: British Film Institute, 2013).

Jones, H., A New Kind of War: America's Global Strategy and the Truman Doctrine in Greece (New York: Oxford University Press, 1997).

Karalis, V., A History of Greek Cinema (New York: Continuum,2012).

Kazamias, A., 'Antiquity as Cold War Propaganda: ThePolitical Uses of the Classical Past in PostCivil War Greece', in D. Tziovas (ed.), Re-imagining the Past: Antiquity and Modern Greek Culture (Oxford: Oxford University Press, 2014), pp 28-44.

Knight, A., 'Documentary - Rallying Point for Europe', Saturday Review (17 February 1951), p. 42.

Laqueur, T., 'Bodies, Details, and the Humanitarian Narrative', in Lynn Hunt (ed.), The New Cultural History (Berkeley, Los Angeles and London: University of California Press, 1989), pp. 176-204.

Logan, P., Humphrey Jennings and British Documentary Film: A Reassessment (Farnham: Ashgate, 2011).

Longo, R., 'Between Documentary and Neorealism: Marshall Plan Films in Italy (1948-1955)', California Italian Studies, 3:2 (2012), pp. 1-45, http:// escholarship.org/uc/item/0dq0394d. Accessed 10 February 2015.

Loukopoulou K., '“A Campaign of Truth”: Marshall Plan Films in Greece', in H. Wasson and L. Grieveson (eds), Cinema's Military Industrial Complex (Oakland: University of California Press, 2018), pp. 321-37.

MacCann, R. D., The People's Films: A Political History of US Government Motion Pictures (New York: Hastings House Publishers, 1973).

McMahon,R. J., The Cold War: A Very Short Introduction (Oxford: Oxford University Press, 2003).

Mehring, F., 'The Promises of "Young Europe": Cultural Diplomacy, Cosmopolitanism, and Youth Culture in the Films of the Marshall Plan', European Journal of American Studies, 7:2, Document 11 (2012), pp 1-28, http:// ejas.revues.org/9701. Accessed 10 April 2016.

Mellor, D., 'Sketch for an Historical Portrait of Humphrey Jennings', in M. L. Jennings (ed.), Humphrey Jennings: Film-Maker, Painter, Poet (London: British Film Institute/ Palgrave Macmillan, 2nd eln, 2014).

Mouzelis, N., Modern Greece: Facets of Underdevelopment (London: The Macmillan Press, 1978).

Nachmani, A., International Intervention in the Greek Civil War: The United Nations Special Committee on the Balkans, 1947-52 (New York: Praeger, 1990).

Pagoulatos, A. and N. Stabakis, 'Greece', in I. Aitken (ed.), The Concise Routledge Encyclopedia of the Documentary Film (New York: Routledge, 2013), pp 324-32.

Reichert, R., 'Culture and Identity Politics: Narrative Strategies in Austrian Marshall Plan Films', in G. Bischof and D. Stiefel (eds), Images of the Marshall Plan in Europe (Innsbruck: StudienVerlag, 2009), pp. 29-38

Rozario, K., "'Delicious Horrors": Mass Culture, the Red Cross, and the Appeal of Modern American Humanitarianism', American Quarterly, 55:3 (2003), pp 417-55.

Saunders, F. S., Who Paid the Piper? The CIA and the Cultural Cold War (London: Granta Books, 1999).

Schulberg, S., Selling Democracy: Films of the Marshall Plan, 1948-53 (New York: Schulberg Productions, 4th edn, 2008).

Schulberg, S., 'Selling Democracy Worldwide', www.sellingdemocracy.org/worldwide.html. Accessed 10 April 2016. 
Simms, B. and D. Trim (eds), Humanitarian Intervention: A History (Cambridge: Cambridge University Press, 2011).

Stollery, M., 'The Newsreel Commentator, the Actor, the Intellectual, and the Broadcaster: Celebrity and Personality Voices in Classic British Documentary', Celebrity Studies, 4:2 (2013), pp 202-18.

Tsilaga, F., 'UNRRA's Relief Effo ts in Late 1944 Greece: Political Impartiality versus Military Exigencies', in R. Clogg (ed.), Bearing Gifts to Greeks: Humanitarian Aid to Greece in the $1940 \mathrm{~s}$ (New York: Palgrave Macmillan, 2008), pp. 189-211.

Whelan, B., 'Marshall Plan Publicity and Propaganda in Italy and Ireland, 1947-1951', Historical Journal of Film, Radio and Television, 23:4 (2003), pp 311-28.

Zachariou, S., 'Struggle for Survival: American Aid and Greek Reconstruction', in M. Schain(ed.), The Marshall Plan: Fifty Years After (New York and Basingstoke: Palgrave Macmillan, 2001), pp. 153-63.

Zachariou, S., 'The Dichotomy of Projecting the Marshall Plan in Greece: The Ideological Battle vs. the Rehabilitation Effo t', in G. Bischofand D. Stiefel (eds), Images of the Marshall Plan in Europe (Innsbruck: StudienVerlag, 2009), pp. 107-14 


\title{
'The most potent public relations tool ever devised'? The United States Peace Corps in the early 1960s
}

\author{
Agnieszka Sobocinska
}

The United States Peace Corps captured the public's imagination in a way that few international development initiatives ever did. Presidential candidate John F. Kennedy fi st uttered the words 'Peace Corps' in early November 1960; two months later, a Gallup poll found that 89 per cent of Americans had heard of the

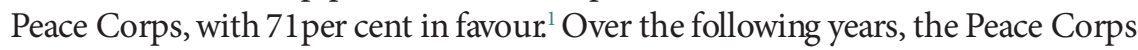
was the subject of countless articles in newspapers and magazines, and featured on the television and on radio. It also intersected with popular culture: portrayed in plays, novels, cartoons, television sitcoms and game shows throughout the 1960s, the Peace Corps helped introduce America's agenda for international development to a popular audience.

Th s chapter explores the nature and eff cts of this publicity during the 1960s. It begins by charting the close alliance that Peace Corps HQ, and particularly its fi st director, Sargent Shriver, built with the burgeoning corporate industries of advertising and public relations. It shows how the Peace Corps rendered international development into a topic for mainstream discussion and public engagement. It also traces some of the political outcomes of this publicity. Peace Corps publicity explained the nature of international development to the broader public in particular ways. First, by focusing on volunteers' altruistic intentions rather than the eff ctiveness of their actions on the ground, Peace Corps publicity portrayed international development as a humanitarian project. By presenting US intervention as a positive expression of American altruism, the Peace Corps helped popularise the view that Americahad a responsibility to modernise the 'underdeveloped' nations of the world. Th s chapter argues that, by privileging American viewpoints and eliding competing visions, Peace Corps publicity helped nomalise a logic of irtervention.

In 2000, NickCullather called on historians to treat 'development as history', and to make 'history the methodology for studying modernization, instead of the other way around. ${ }^{2}$ Historians have taken up the challenge, producing some important workon modernisation and aid projects in Asia, Latin America and Africa. Scholars have focused particularly on the Cold War context, and how this influ nced policy 
makers in organisations such as USAID. ${ }^{3}$ Historians of development have begun to look beyond the bureaucrats, academics and politicians who devised policy, to investigate how the public engaged with international development during the $1950 \mathrm{~s}$ and 1960s. ${ }^{4}$ Th s chapter extends such work by focusing on the role played by media and popular culture in constructing public images of international development, with particular reference to the United States Peace Corps. Thecultural signific nce of the Peace Corps in America has long been acknowledged. By 1966, anthropologist Robert Textor had identifi d a 'Peace Corps mystique', which att acted widespread interest and helped maintain public support for the programme ${ }^{5}$ In her monograph covering the fi st decade of the Peace Corps, Elizabeth Cobbs Hoffman argued that the programmegained widespread popularity because it 'symbolised what America wanted to be, and what much of the world wanted America to be: superhero, protector of the disenfranchised, defender of the democratic faith ${ }^{6}$ Whilst more critical of the Peace Corps, and focused on its gender politics, Molly Geidel has similarly pointed to its currency in the popular culture of the 1960s. ${ }^{7}$ The historical literature has built our understanding of the Peace Corps' operations during its fi st decade, but we do not yet have a sustained analysis of the Peace Corps' publicity or representations in populdr alture.

Ths chapter uncovers the construction of a Peace Corps mystique by publicity experts and the media, and tracks its reception by popular audiences in the United States. Based on archival research, media sources and analyses of popular cultural productions, it is attentive to both the producers and audiences of media and popular culture. It argues that the Peace Corps' publicity helped stir public interest and support for international development, and contributed to widespread acceptance of Western developmentalist intervention in the thid world.

\section{Cultures of publicity}

It was 2 a.m. by the time presidential candidate John F. Kennedy ascended the dais at the Cow Palace in San Francisco on 2 November 1960. Yet, as theNew York Times reported, it wasn't long before the 20,000-strong crowd was 'roaring' in approval at Kennedy's proposal to establish a Peace Corps of young Americans serving in technicalaid roles abroad. ${ }^{8}$ Theidea received widespread press coverage. The New York Times reprinted lengthy extracts from Kennedy's speech the next moming, and over thefollowing days, articles introduced the Peace Corps to readers around the nation. Ordinary Americans responded with great enthusiasm. In the following months, Kennedy's office received somewhere between 30,000 and 40,000 letters; Cobbs Hoffman estimates that more people off red to work for the as-yet non-existent Peace Corps than for al the existing agencies of government combined. ${ }^{9}$

Kennedy assigned his brother-in law, Robert Sargent Shriver, to head the Peace Corps. Both men were keenly aware of the importance of public opinion Shriver engaged public relations experts to sketch the basicoutlineof a vast publicity strategy 
even before the Peace Corps was formally constituted on 1 March $19611^{10}$ Shriver's PR outfitsoon boasted a full-time Associate Director of Public Affai s; withina couple of years, the Public Affai s section had grown to accommodate separate departments for Public Information, Communications, and Radio and Television.

Shriver forged close relationships with corporate public relations and advertising agencies. The US government had begun to use corporate advertising agencies during the Second World War, and this became increasingly common as propaganda activities became centralised during the Cold War. ${ }^{11}$ Shriver brought the talent and glamour of both Hollywood and Madison Avenue to bear on the Peace Corps' image. He looked for people with Hollywood connections to add glamour to his agency, and poached well-connected journalists to act as in house publicists. Terry Turner, the Peace Corps' Director of Radio and Television in the mid-1960s, characterised his career trajectory as being 'From Madison Avenue to Malawi.' ${ }^{12}$ In addition to in house staff, Shriver engaged external PR consultants, and the National Advertising Council contributed by appointing corporate agencies including Young and Rubicam to work for the Peace Corps to fulfil their public service contribution.

Together, these agencies saw the Peace Corps message carried in hundreds of posters and pamphlets as well as countless advertisements in national, regional and college newspapers and magazines. Theyinvested heavily in radio advertising. The Peace Corps also commissioned dozens of films, starting with Peace Corps in Tanganyika (1962). Screened on national television, and at hundreds of university campuses and high schools across the United States, these were regarded as an important recruitment tool throughout the $1960 \mathrm{~s} .{ }^{13}$ Shriver was particularly telegenic, and he maintained a punishing schedule of news and current affai s shows, as well as radio programmes. The publicity profile was unusually high for the head of a government agency, and it helped sustain the public's initial enthusiasm over the coming years.

Theconstant stream of publicity contributed to the Peace Corps mystiqueidentifi d by Textor, which had 'a direct, fresh, personal appeal to millions of Americans.' ${ }^{14}$ Exceptionally for a government agency, the Peace Corps acquired mainstream, pop culture glamour Even celebrities floc ed to be associated with the Peace Corps. Notable individuals, from Harry Belafonte to football stars to anthropologist Margaret Mead, off red their suggestions and services. ${ }^{15}$ A young Clint Eastwood wrote to President Kennedy in March 1961, off ring to create what he called 'a volunteer entertainment group to supplement the work of the Peace Corps. ${ }^{16}$ At this time, Eastwood starred in the CBS series Rawhide, which was the sixth-highest rating television programme in the United States. The letter was prioritised and evidently provoked some discussion amongst Peace Corps staff, but Eastwood was ultimately turned down. The United Nations had begun to use celebrity 'Goodwill Ambassadors' to promote its international development programmes from 1954, in the hope that their profile and glamourmight rub offon the rather sombre topic of international development. ThePeace Corps was placed in the unusual and enviable 
position of being pursued by actors, athletes and other celebrities who wanted to have some ofits glamour mb off o them.

\section{The Beautiful Americans}

Theprevious section established the extent of the Peace Corps' publicity, but what messages did it convey? Despite its global vision, Peace Corps publicity was overwhelmingly focused on America. In publicity, the Peace Corps was framed as an expression of American goodwill, and Peace Corps volunteers as the personific tion of everything good about the United States. As Cobbs Hoffman notes, 'at its inception the Peace Corps told Americans what was best about theircountry. ${ }^{17}$ Th s message, present in Kennedy's early speeches, was sharpened through the Peace Corps publicity machine. The foregrounding of American motivations was politically important for the Peace Corps. It served to assuage early critics in Congress, many of whom had to be convinced of the national benefitof international development. It also served to counter rising critiques of American culture. As Shriver put it, there was a 'widespread belief that many Americans have gone soft', and the Peace Corps was presented as a corrective. As Shriver went on, 'the exciting thing about the Peace Corps is that we are fin ing the Americans who have the faithand the conviction' to lead the free world. ${ }^{18}$

Geidel has located anxieties that America was going 'soft' in masculinefears about the dual encroachments of consumerism and feminism. ${ }^{19}$ Cold War politics also played an important role. International development assistance became another front in the Cold War during the $1950 \mathrm{~s}^{20}$ Unflattering contrasts between American softn ss and the determination of the Soviet Unionfigured prominently in critiques of the US approach to international development. Proving that America had the resolve to 'lead the free world' became a core priority amidst the Cuban Missile Crisis and growing unrest in Vietnam. ThePeace Corps was presented as an answer. Hollywood producer Michael Abbott thought it was 'without doubt, the most potent public relations tool ever devised', as 'for those parts of the world inflamed with anti-Americanism, America's Peace Corps will be the salve and the counterirritant to the infectiousspread of the "ugly American". 'Th s was a riposte to Lederer and Burdick's vastly influ ntial 1958 novel The Ugly American. In the novel, American haughtiness and indolence was contrasted with the grassroots approach of Soviet aid experts, who won villagers over to the communist cause by sheer hard workand determination. Abbott thought that the Peace Corps was America's answer. Far from ugly Americans, the Peace Corps would be 'beautiful Americans ... bringing hope and trust and self-esteem.' ${ }^{21}$

In print, on radio, on $\mathrm{TV}$ and in countless recruitment drives at college campuses, early Peace Corps publicity emphasised Americans' good intentions in order to claim a moral right to leadership of the free world. Recruitment publicity emphasised volunteers' altruism, whilst omitting details about the work they would 
do, or why it was needed. One of the earliest official Peace Corps publications, the Peace Corps Fact Book began with the question, 'Why a Peace Corps?' As an answer, the Fact Book reaffirmed Western motivations, writing that 'the Peace Corps idea ... has demonstrated a strong appeal to the idealism and altruism of Americans.22 References to Kennedy's New Frontier, whichsought to revive America's pioneering spirit and harness it to international causes, were frequent. Americans were shown to be eager and ready for hard work, but Peace Corps publicity rarely explained what kind of workthey would do beyond generalities such as 'teaching' or 'helping', or why their presence was required. Signific ntly, Peace Corps publicity did not explain the need for American intervention abroad, presenting the vast enthusiasm of Americans as justific tion enough. Voices from recipient nations were almost entirely absent. A one-minute radio spot produced in early 1962 by Chicago-based agency Doherty, Cliffo d, Steers and Shenfi ld is illustrative of the determined focus on American motivations:

Probably no public activity has ever captured the imagination and interest of the country - and the world - as quickly, as has the Peace Corps. Many see it as a way in which America can help in the world-wide fight for freedom among new and rising nations - and it is. Many see it as a way to serve humanity in the battle against poverty, ignorance and hunger - and it is that, too. Still others feel about the work of the Peace Corps as their ancestors felt about the opening of our own West - and it is true that many of the same traditional American characteristics are needed for Peace Corps work as were needed then. Today, Peace Corps volunteers are working, teaching, helping people in Africa, Asia and South America - and requests are pouring in for moe..$^{23}$

In addition to commissioned recruitment material and in house publications, Peace Corps HQ worked closely with private authors to produce works that blurred the line between publicity and reportage. The same focus on volunteers' motivations was also commonin books and pamphlets written about the Peace Corps. Dozens of Peace Corps staff collaborated with joumalist Roy Hoopes to produce the 1961 Complete Peace Corps Guide. In tone and content, Hoopes's workwas virtually indistinguishable from official publicity; the line was blurred further by the inclusion of an introduction penned by Shriver. Like official Peace Corps publicity, Hoopes located the purpose of the Peace Corps in its ideals rather than its eff cts. 'Whether or not we ... have a signific nt impact on the economiclot of the countries where they will serve does not make any diff rence', he wrote. 'Thepoint is that thousands of young Americans are willing to help and are willing to make sacrifi es to do so; the principal purpose of the Peace Corps is to provide the organization through which this desire can be channeled.24

Much of the Peace Corps publicity was produced as an answer to the image of the 'Ugly American'. However, publicity focused on Peace Corps volunteers' beauty in a literal sense, too. Photographs of volunteers at training, work or lesure abounded. The centrepiece of a 1963 Paperback Library volume, The Peace Corps, intended for 
mass distribution at a low cost, was a sixty-four-page collection of photographs contributed by Peace Corps HQ. ${ }^{25}$ The vast majority of images portrayed Peace Corps volunteers as young, att active and energetic. Whilst the photographs were clearly staged, only a few were posed. The stress was on action, with a disproportionate number of images capturing volunteers undertaking physical activities. Photographs of pre-departure training depicted male volunteers performing backbends and female volunteers rope climbing and abseiling. Partly, this was designed to appeal to potential volunteers, many of whom were att acted to the Peace Corps precisely because of their dissatisfaction with the conventional, highlygendered life awaiting them in the United States. ${ }^{26}$ However, the parade of youthful, att active young bodies also underscored the notion that America's best and brightest were eager to devote themselves to international development, thus confi ming America's fitn ss for moral leadership. The images portrayed Peace Corps volunteers as Beautiful Americans, both in body ad in spirit.

Of course, not every Peace Corps volunteer was young and beautiful. Most Peace Corps volunteers were in their mid to late twenties, but even septuagenarian volunteers were not uncommon Yet, Peace Corps HQ liked to portray its volunteers as att active and glamorous, with a particular focus on good-looking women. In 1968, seven years after writing The Complete Peace Corps Guide, Roy Hoopes returned to the subject with a pictorial collection, The Peace Corps Experience. Part of the collection was devoted to a photo-essay tilted 'Pretty Girls: ThePeace Corps Has Its Share'. Running over fourpages, this depicted ten female volunteers teaching classes in Africa, Asia and the Middle East. Thetext accompanying the photographs claimed that 'Everybody remembers falling in love with the pretty young teacher at one time or another in their school days, and the boys who have Peace Corps teachers will no doubt face the same hazards. ${ }^{27}$ Depictions of att active volunteers, with whom the locals 'no doubt' fall in love, suggested that American development intervention was eagerly desired. The absence of genuine local voices speaking for themselves, rather than having their desires ventriloquised by American writers, left little room for contradiction. Focusing on female beauty, The Peace Corps Experience presented volunteers as appealing counterpoints to the 'Ugly American'.

Th oughout its early years, publicity was fixated on the volunteers, with relatively little attention devoted to the other side of the equation - that is, the people and places receiving Peace Corps volunteers. Cullather notes that 'developmentese became the Kennedyadminstration's court vernacular', but this was rarelytranslated for a broader public. ${ }^{28}$ Rather than engaging with modernisation theory, or with the histories, economies and cultures of nations in Africa, Asia and Latin America, Peace Corps publicity presented a simplifi d account of Americans assisting 'underdeveloped' nations. Ths refl cted Kennedy and Shriver's vagueness in explaining what the Peace Corps would do, and where it would serve. When Kennedy fi st announced the Peace Corps in late 1960, he merely noted that volunteers would serve 'abroad'. Th s imprecision was preserved in the Peace Corps Act, passed by 
Congress in September 1961, which failed to definethe Peace Corps' area of service, referring to it onlyas 'these countries. ${ }^{29}$ Theambiguity of 'these countries' or 'underdeveloped nations' was in keeping with the development discourse of the 1960s. As Rist notes, development discourse subsumed economicand regional specifi ities to a binary between 'developed' and 'underdeveloped' nations. ${ }^{30}$

Leaving the area of service ambiguous allowed the 'underdeveloped world to be imagined asa tabula rasa uponwhichthePeace Corpscouldinscribeitsachievements. In 1962, the New Yorker interviewed Harris Woffo d, Special Representative for the Peace Corps in Africa. In an article titled 'Pioneers', Woffo d claimed that 'the greatest future for the Peace Corps is in Africa', because 'It's so wide open. And limited only by our imagination. It's an empty continent'. He went on: 'You get a feeling that that must be like what the people felt who fi st saw America... The 're starting out with a clean slate. ${ }^{31}$ Such publicity was far removed from reality. Rather than pioneers starting with 'a clean slate', most Peace Corps volunteers were placed in established communities. The largest number of volunteers was employed as teachers, often delivering existing curricula in established schools. Many volunteers were based in cities, and enjoyed at least some modern comforts. Yet, neither the publicity nor media acknowledged this fact, instead preferring to portray volunteers as 'pioneers' in the ambiguous category of 'underdeveloped' nations.

\section{Peace Corps in the media}

In addition to formal publicity, the Peace Corps att acted a great deal of media coverage in the United States. Thevast majority of press coverage was positive. As its First Annual Report noted, 'press comment on the Peace Corps has been generally favourable', and at times, it was 'overwhelmingly so. ${ }^{32}$ Taking its mark from official publicity, the media focused onvolunteers, rather than thetaskof modernisationand what it involved. The mainstream press regularly portrayed Peace Corps volunteers as 'Beautiful Americans'. Hilda Espy Cole's 1962 article in the Atlantic Monthly was based on a visit to the Peace Corps training camp in Puerto Rico. Illustrated with photographs of a young, blonde female volunteer abseiling, the article claimed that 'volunteers must be sturdy, have the skills of pioneers and a proud team spirit." The relationship between abseiling and a volunteer posting in a Filipino school (to take one of the most common positions in the early years) was always problematic, and, internally, Program Directors worried that 'the jungle camp experience tends to produce in the trainee an inappropriate sense of confid nce ... verging on arrogance, [which] is exactly the opposite of the humility which ... shouldbe the hallmark of the good PCV ${ }^{34}$ But it formed a core element of the public image of the Peace Corps, reproduced in numerous articles.

Media coverage of the Peace Corps generalised and simplifi d conditions in the developing world. As previously noted, this was in keeping with development discourse. Removing any specific context, however, also allowed the media to run with 
crude assumptions about developing nations. Many reports assumed that volunteers would live in mud huts in rural villages far from civilisation. A common trope removed them even further. Cole Espy thought that the distance between America and 'under-developed' countries was so great it could onlybe expressed in temporal, rather than geographical terms. She depicted the Peace Corps volunteers as having gone 'backwards in time', so that they grappled with 'the realities of life in primitive places. ${ }^{35}$ Cole Espy's depiction of underdeveloped nations as 'backwards in time' was echoed in numerous media reports. It also featured in published accounts: The Complete Peace Corps Guide claimed that the Peace Corps served in parts of the world where 'history has not happened'; the Paperback Library edition of the Peace Corps wrote of volunteers serving in daces where 'time seemed to have stopped." ${ }^{36}$

A good deal of coverage focused on the volunteers before theirdeparture, profiling their training or asking about their motivations. Coverage that followed volunteers overseas was less common Th se reports often discussed the 'primitive' conditions they would live in, but retained a resolute focus on the volunteers. Often, the aim was not to present an accurate picture of conditions in 'underdeveloped' nations, but to accentuate the extent of volunteers' sacrifi e. Time magazine profiled the Peace Corps in July $1963 .{ }^{37}$ The cover, a portrait of Shriver flanked by volunteers working with attentive Asians and Africans, featured a banner denoting the Peace Corps as 'A US Ideal Abroad'. The article began with a sense of irony, noting that 'from the front porches of the US, the view of the Peace Corps is beautiful, in so far as the 'image is that of a battalion of cheery, crew-cut kids', who 'have all but won the cold war' through 'the application of Good Old American Know-How and That Old College Spirit'. However, Time wrote, 'as so often happens, the image is glossier than the reality'. Far from 'glimpses ofglory', the articledepicted volunteers who had 'been racked by illness and bedded down in squalor' and who 'wrestled with tongue-twisting languages [and] gagged on incredible foods containing everything from cat meat to sheep intestines to fish heads'. Theyhad also 'cursed the mistakes of their superiors and muttered in fury at the ignorance and inertia of the ratives they are trying to help'.

Yet, Time's portrait was by no means critical; indeed, emphasising the difficulty of their postings only served to further entrench the Peace Corps mystique. Time fetishised the difficulties of Peace Corps life in order to counter criticisms that a 'Kiddie Corps' would be unable to face the tough reality of underdevelopment. The Peace Corps experience may have been rough, but Time thought 'the reality is more meaningful than that unflawed popular image'. As with official PR, Time's measure of success was set on America's terms. Ultimately, it was decreed a triumph, as 'in scores of small ways, through theirown zeal and ingenuity, the Peace Corpsmen have made a disproportionate number of friends for the US'. Because of this, Time decreed it 'probably the greatest single success the Kennedy Adminstration has produced'.

Going backin time, and giving up modern conveniences, was presented as a sacrifi e that deserved the respect and gratitudeof the American nation. A 1966 New York Post profile of Kenya volunteer Philip Shaefer emphasised the difficulties of Peace 
Corps service in order to heighten veneration forvolunteers. ${ }^{38}$ Titled 'Peace Veteran', the article claimed that Peace Corps volunteers were 'exposed to varied forms of disease and danger', and 'rendered a form of distinguished service under a special kind of emotional fi e.' By likening the Peace Corps to active military service, the New York Post tapped into idealised images of the veteran to thwart critiques that Peace Corps volunteers were draft-dodgers. As Cobbs Hoffman and Geidel have shown, this was one of the few negative images of the Peace Corps to gain traction during the programme's early years. ${ }^{39}$ Coverage such as the New York Post article served to negate charges that volunteers were taking the easy option. Schaefer had 'been through two rough years' - so much so that 'one can onlyimagine how much private trial he has survived or how much hidden strength he discovered on this journey'. In articles such as this, Peace Corps service was rendered into 'the moral equivalent to war' - 'but let no one suggest that they have a soft, easy time on these lonely fronts. In a better hour they may be accorded some of the honors now reserved for the vliants of the battlefields. ${ }^{40}$

The Peace Corps mystique focused on volunteers as agents, with host locations relegated to backdrops and locals portrayed as passive recipients of the Peace Corps' dynamism. Media representations of the Peace Corps, therefore, located the source of the programmés success in the American volunteers. Ironicaly, this caused significant problems withinthe organisation. As Shriver noted in a congressional message in 163 , 'volunteers and staff a ike have the feeling that the Peace Corps stories most often repeated are too glamorous, too glowing, too pat', and ignored 'the day-to-day problems, the frustrations, the harsh disappointments." The Peace Corps mystique had become a liability in that many volunteers didn't feel like theirexperiences lived up to the ideal. Returned volunteers complained that 'the gap between what they felt they ought to achieve and what they were actually achieving was so great as to produce, in many cases, considerable anxiety and guilt.".2 As Shriver noted, 'the most unsett ing challenge the volunteer faces is his publicity.43

Anxiety and guilt could turn to anger. As Geidel has shown, by the late 1960 s a number of returned volunteers were severely critical of the Peace Corps. ${ }^{44}$ At the height of the Vietnam War in 1970, the Committee of Returned Volunteers called for a boycott of the Peace Corps, arguing that volunteers co-opted previously selfsustaining foreign societies into Western capitalism and US hegemony. Yet, the glowing image of the Peace Corps proved impossible to shift. Thereturn of Iran volunteer Barkley Moore, who served for fi e years from 1966, provided the space for coverage so positive it verged on hagiography. TheNational Observer profiled Moore in a 1971 article titled 'The Beautiful American'. It portrayed Moore in superhuman terms: he was 'able to move people to accomplish what they said was impossible'. One former supervisor was quoted as saying, 'He's the only peson I've ever met ... who makes you want to say, "I'll follow you anywhere"' ${ }^{45}$ Even into the 1970s, amidst rising opposition to America's overseas interventions, the image of the Peace Corps volunteers as the Beautiful American endured. 


\section{Peace Corps in popular culture}

ThePeace Corps was integrated into numerous mainstream cultural productions. As Geidel notes, it featured in at least fourteen novels and two plays during the 1960s. ${ }^{46}$ Just as signific nt was the Peace Corps' presence on television, whichemerged as the domimant media format in the $1960 \mathrm{~s} .{ }^{47}$ Shriver was eager to capitalise on the publicity potential of television, and Hollywood producers were att acted by the promise of a broad audience. It seemed a natural match. The Westinghouse Broadcasting Company (WBC), which owned a number of television stations, was the fi st to off $r$ its services. Ten days after the Peace Corps launched in March 1961, WBC presented President Kennedy with a television concept that would blur the lines between popular entertainment, private profi, domestic politics and international relations, predicting that television programming about the Peace Corps wouldhelp 'strike a new force for American prestige in the international fi ld'.48

Shriver soon established a separate Radio and Television Division to focus publicity through these media. Th oughout 1962 and 1963, the Radio and Television Division contemplated a flagship TV serial. Several production companies competed for the rights to this program; Variety reported that 'everybody wants to get into the act'. Producer Danny Mann drew together support from UniversalRevue and NBC, and recruited Kaiser Aluminiumas a potential sponsor. Variety speculated that Mann had also recruited famed writers including James Mitchener, Carl Sandburg and Archibald MacLeish, briefi g them that 'the language ... should be deep feeling.' ${ }^{49}$ Although Mann regarded this as a 'coup for Hollywood', he also considered a TV program about the Peace Corps to be the "best way to channel our American way of life to the norld. ${ }^{50}$

Mann's treatment was predicated on the premise that 'Peace Corps is people', and proposed to focus on the human drama of cross-cultural encounter rather than on the detail of the workdone 'Theway in which a Peace Corps volunteer, for example, may help another human being to irrigate a rice fi ld is interesting', Mann's pitch went, "but not nerly as aresting as a evelation of the enotional conflicts that arise between the two.' That conflict would not only be dramatic, but also didactic: 'The resolution of those conflicts will reveal to our audience the capacities of human beings to live and learn and share a commonexperience that brings together men's minds as well as there $[s i c]$ heart. ${ }^{51}$

Mann's proposal aroused a great deal of debate at Peace Corps HQ. The Radio and Television Division thought highly of the pitch, at one point noting that the proposed format 'would be perfect. ${ }^{52}$ However, the proposal to blur politics and entertainment provoked difficult questions. Should the Peace Corps lend its official endorsement to a fic ionalised drama? Shouldit demand script approval? Doug Kiker and Norman Shavin from the Radio and Television Division recommended caution. The Peace Corps should 'endorse nothing officially', they argued, for the simple reason that 'the show might, despite all our effo ts, be a dog. ${ }^{53}$ Peace Corps 
Deputy Director Bill Moyers disagreed. 'Any weekly TV show that carries the name "Peace Corps" or deals with the Peace Corps will in the public's mindhave Peace Corps approval, whether a trailer credit is carried on each episode or not', he wrote. 'That being true, we will be responsible, in the public's mind for the proper projections of the Peace Corps'. Moyers recommended the Peace Corps demand strict controls, includng script approval rights. ${ }^{54}$

In the end, Mann's sample script did not measure up to expectations. (Kiker opined that it is a lot of cap ... full of big words and fuzzy ideas'). Other proposals also came to nothing. While plans for a flagship TV serial never eventuated, the Peace Corps featured in numerous syndicated variety shows, serials and sitcoms throughoutthe 1960s. Thepopular Gertrude Berg Show ran an episode with a Peace Corps plotline in 1962. That same year, the Peace Corps proposed a regular segment to NBC's Jack Paar Program, a primetime vehicle for the former host of the Tonight Show. Rather than dramatisations, the Peace Corps envisioned short segments starring real volunteers at work, 'which refl ct the best in America':

In the matted reaches of Malaya, an American girl nurses 80 lepers, doing it alone ... In Sierra Leone, young Americans, teaching in the schools, spend their spare time showing crippled children and African policemen how to swim ... In Tanganyika, a Japanese-American lad spent so much spare time with the Wagogo tribe that he will becomean honorary member ... Th se are but a few of the hundreds of touching, dramatic and humorous stories about Americans abroad - the Peace Corps Volunteers.

In keeping with the Peace Corps mystique, the focus remained fi mly on the volunteers, withlocals portrayed as passive, grateful tribes rather than agents in their own right. On television, Peace Corps publicity portrayed volunteers as simultaneously humanitarian and heroic, nursing lepers and teaching crippled children and authorities alike. Th s image was in keeping with the Peace Corps' broader publicity strategy of focusing on individual volunteers rather than the broader development context.

Peace Corps HQ never managed to exert control over all the televisionshows that featured volunteers in their storylines. Yet, even in the absence of official oversight, depictions did notstray far from the official script. Thepopular ABC sitcom The Patty Duke Show aired the episode 'Patty and the Peace Corps' to a nation-wide audience on 11 November 1964. In this episode, Patty - a loveable teenager always getting herself into scrapes - secretly signs up to the Peace Corps. As with the official publicity, the show's focus was on American volunteers' motivations rather than the eff cts of their work on the ground. Patty's success in being chosen for the programme is portrayed as a great honour, in the episode, she is interviewed for the local newspaper and even her teenage nemesis, Sue Ellen, thinks that Patty's assignment is 'the most exciting thing I've ever heard of!' Explaining why she signed up, Patty dreamily likens Peace Corps volunteers to 'the great humanitarians. Albert Schweitzer, Clara 
Barton, Betsy Ross'. Explaining what an unqualifi d teenager, still in high school, can off $r$ the developing world, Patty replies 'a littleskill can go a long way in those countries'. She explains, 'I'm teaching English but that's just the beginning. Once I get there I'm going to spread around some good old American know-how' ${ }^{55}$

As with official publicity, the nature and location of the Peace Corps' work was glossed over. Patty assumed that the Peace Corps would send her to Africa, which the sitcom portrayed as 'a primeval paradise ... Man pitted against raw nature'. References to Africa's 'darkness' were recurrent, as when, for example, Patty explained 'I want to light a candle in the darkness'. The Peace Corps storyline gave The Patty Duke Show a chance to rehash stereotypes that bordered on caricature. Patty decorates her suburban bedroom with masks and shields, learns to drum the message 'take me to your leader' and practices a 'tribal' dance by throwing a spear at a dartboard. Patty also attempts to prepare 'native' foods, as 'we have to live like the natives ... share the same kind of living accommodation, eat the native food'. As Patty explains, 'in certain parts of Africa grasshoppers are a rare delicacy', and so she set out to capture one - before fin ing that she couldn't bring herself to kill an insect. She then goes on to make grass soup from the cuttings of her lawn, whichunsurprisingly proves to be no moe palatable than the gasshopper.

Although it was produced withoutagency approval, 'Patty and the Peace Corps' followed the discursive path set by the Radio and Television Division of Peace Corps HQ. By focusing on American volunteers' good intentions, the Patty Duke Show portrayed the Peace Corps, and by extension the United States, as a global force for good. In positioning the Peace Corps amongst the 'great humanitarians', it represented international development as an act of altruism, designed to assist those in developing nations. It also justifi d American intervention, as 'a little skill can go a long way in those countries', and America possessed a great deal of 'know how'. Th s language mirrored that of media reports such as Time magazine's 1963 cover story, further revealing the close ties between official publicity, media coverage and popular culture. Yet, as Arturo Escobar has demonstrated, international development was always contested. ${ }^{56}$ During the 1960 s, organised opposition movements against the Peace Corps arose in Nigeria, Indonesia, Bolivia and Chile, among others. ${ }^{57}$ Popular representations elided the broader reality in which the Peace Corps operated by focussing on the volunteers' ideals, and their willingness to endure rough conditions without taking an interest in the ontexts in which they opeated.

\section{Public interest and political effect}

So far, this chapter has traced publicity, media and popular culture portrayals of the Peace Corps. But how did the American public receive and understand those images? Gauging audience responses is notoriously difficult, but the tens of thousands of letters that were hauled into Peace Corps HQ off r some insights. Letters posted to the president and the Peace Corps provide some evidence of the 
diffusion of official and unofficial images. Theyalso allow a rare glimpse into public opinion surrounding the Peace Corps, and, more broadly, about America's role in the 'underdeveloped' world, during the early 1960 s.

As Rottinghaus notes, the practice of writing letters to the president was long established by the time of the Kennedy adminstration ${ }^{58}$ Kennedy received thousands of letters about the Peace Corps, which, as his administrative secretary noted, was the issue that 'most consistently produces responses through mail. ${ }^{59}$ Heaving mailbags were also dragged into the Peace Corps' Washington offices each moming. In 1970, well after the fi st surge of enthusiasm had died down, the Communications department still processed approximately two-thirds of a ton of mail every day. ${ }^{60}$ The US National Archives holds several boxes of Peace Corps mail briefs from the early 1960s. Letters came from almost every US state, from Alabama to Wyoming. Although most correspondence came from within the United States, letters also arrived from around theworld.

In the early years, the vast majority of correspondents were extremely enthusiastic. Fifteen-year-old New Yorker James Pastena wrote in July 1961 to express his support for this 'excellent idea', even though he was still too young to join. ${ }^{61} \mathrm{On}$ the other end of the age scale, eighty-two-year-old Walter Robb also gave his full support, seeing in it many possibilities that theirgeneration did not have.6. A great number wrote to apply for the Peace Corps, and others recommended an applicant. The tone and syntax of many letters refl cted the tone of Peace Corps recruitment and publicity material, assuring Shriver that applicants were fit for the Peace Corps because they were 'serious, intelligent, att active, tactful and dunble.63

Many letters spoke to hours of thought and creative effot. Dozens of correspondents enclosed insignia, symbols and badges that they had designed for the Peace Corps. ${ }^{64}$ One of Senator Henry M. Jackson's Washington State constituents even redesigned the American flag so that it better refl cted the Peace Corps' objectives. ${ }^{65}$ Others submitted poems, stories, songs, anthems, jingles and mottoes to 'educate those ignorant and apathetic Americans' about the Peace Corps and world affai s. ${ }^{66}$ Others still promised to talk to their friends and families, or even to travel the country 'under Peace Corps auspices, spreading goodwill'. ${ }^{67}$ Leon A. Jaris, an adminstrator in a Californian hospital, wrote to propose 'a total PEACE OFFENSIVE, by which 'idle factories and farming lands could be turned into training centers here for foeign mationals, staff $\mathrm{d}$ by our unemployed as teachers. ${ }^{6} 8$

Alongside such off rs were more tangible donations of books, food, clothing and money which poured in from private individuals, community groups, schools and private companies. Anna Steiger of Long Island forwarded a check for thirty dollars 'to aid the Peace Corps movement', adding that only her two small children prevented her from signing up. ${ }^{69}$ Seventh graders from Lincoln Junior High School in Ferndale, Michigan, sent \$66.46 in the hope that 'the Peace Corps will find it helpful. ${ }^{70}$ Fourth graders at the New Lincoln School of New York collected 200 books, which they hoped could be distributed by Peace Corps volunteers in 
Africa; their effo ts were surpassed by the students of Brookline High School in Massachusetts, who collected sixty-fi e boxes of books. ${ }^{71}$ On a slightly diff rent note, the Catholic Youth Organization of New York hoped to spend the summer of 1961 growing fruit and vegetables that they would then donate to Peace Corps volunteers heading to Tanganyika. ${ }^{72}$ Community groups were similarly enthusiastic: the New York State English Council, the American Vegetarian Party and the American Society of Traffi and Transportation were among scores of groups that placed theirresources at the Peace Corps' disposal. ${ }^{73}$ Religiousorganisations ranging from Methodist student groups to Jewish community organisations and Catholic schools also wrote to express support and off $r$ their asistance.

Although they brimmed with goodwill, many correspondents were vague about the purpose of the Peace Corps. Was its purpose, as Elliot Forbes of the Harvard Glee Club thought, 'to promote world peace'? ${ }^{74}$ Or was it another weapon in America's Cold War armoury? New Yorker Blair Rogers wrote to say that he thought the 'Youth Corps' was 'one of the most encouraging developments to people who, like himself, have returned from the Soviet Union with an increasing worry about the need for an ideological fervour in our own people.75 A New Jersey correspondent suggested that 'a further step to the Peace Corps' would be a specialist 'group of young Americans skilled in debating to act as America's "intellectual commandoes" ${ }^{76}$ However, others thought that the purpose of the Peace Corps was purely humanitarian, and protested any suggestion of realpolitik. Pat Montague of Seattle felt that 'the Peace Corps shouldnot get tangled in foreign policy and politics'. Pointing to the situation in Peru, where a military junta had overthrown the recently elected government, Montague argued that if the purpose of the Peace Corps is to be humanitarian it should be allowed to go to Peru despite diplomatic relations', as he could not see 'why the needs of the people shouldbe denied because the government in power is not to our lking.'77

Perhaps unsurprisingly, considering the imprecision of publicity and recruitment material, many Americans were confused about the countries where Peace Corps volunteers would serve. While many letters used the technicallanguage of 'developed' and 'underdeveloped' nations, others used vernacular terms such as the 'poor' or 'have not' nations. Some correspondents freely admitted their confusion Texan Ray Greene, for example, wrote specifica ly to request infomation from the Peace Corps on underdeveloped nations. ${ }^{78}$ Others made telling assumptions about where Peace Corps volunteers would serve. A. W. Dawson of New Yorkthought that the Peace Corps sent youngsters to 'the wilds of Africa' and other places 'withoutthe convenience of modern civilization. ${ }^{79}$ However, many others assumed that the Peace Corps would serve in nations that were already ind ustrialised, thus revealing a broad ignorance of the nature of underdevelopment (or indeed development). In March 1961, Californian John F. Spence wrote to seek a Peace Corps placement in Japan. ${ }^{80}$ Others wrote hoping to serve in Germany, Hungary or Israel. In late 1961, two of Congressman William Cramer's Florida constituents separately wrote to express 
their desire to serve in Britain ${ }^{81}$ Th se letters, amongst thousands more held in US archives, point to a low level of knowledge about the nature and location of underdevelopment. Th se commonblind spots refl cted the ambiguities of Peace Corps rhetoric and publicity material.

Despite this ambiguity, many correspondents expressed support for America's intervening in foreign countries in order to bring about development. Egon W. Mueller of Escondido, California thought that although so far 'foreign aid has been detrimental, to a great degree' there was now the 'opportunity to correct this in establishment of Peace Corps. ${ }^{82}$ Many Americans wrote to propose schemes to place even more Americans abroad. Cecil Powell of Jacksonville, Florida, suggested 'the government hire several hundred unemployed farmers and send them overseas ... to countries, predominantly coloured, and teach those in underdeveloped countries how to raise crops. ${ }^{83}$ Charles Hoffner of Philadelphia thought what was needed was 'filling people with hot dogs, milk shakes and ... soda fountains. ${ }^{84}$ Embedded in such proposals was the assumption that the developing world was a blank slate that warranted America's intervention. Proposals to send Americans to teach people how to farm, or to feed them American foods, overlooked existing agricultural knowledge and foodways, many of which were suited to local environmental conditions. In addition to providing a platform through which the public engaged with foreign aid and international development programmes, the Peace Corps also encouraged refl ction regarding the United States' role in theworld.

Others were not so sure about America's involvement. W. H. Owens of New Hampshie liked to spend his winters in Jamaica, where he had observed Peace Corps volunteers at work. Returning home, he off red Sargent Shriver 'some rather disturbing observations'. Amongst other things, the Peace Corps were teaching Arts and Crafts, whichis 'a waste of time' as 'the natives do quite well with their own arts and craft ${ }^{3}{ }^{85}$ Similarly, Laurence S. Moore wrote a letter to the Peace Corps following a trip to Turkey in June 1961 . He wasn't convinced that it wouldbe possible to change Turkey for the better, and indeed, felt " "raising the spirit of living" in any country is just a dream. ${ }^{36}$ Floridian E. A. Munyan similarly thought 'the people do not want to be changed' and 'we are fools to spend moneyto try and change the way they have been doing things for enturies. ${ }^{87}$

It is difficult to gauge the extent to which Peace Corps publicity and popular culture portrayals helped shape the views held by these correspondents, or indeed the wider public. As with all issues of popular opinion, it is impossible to point to a single driver. Personal histories, ideologies and personalities all had a role to play alongside broader discourse. Yet, the letters reveal an audience attun $\mathrm{d}$ to Peace Corps publicity. As President of the University of Notre Dame Th odore Hesburg wrote in 1961, the Peace Corps is getting 'lots of press coverage, radio and TV time, and consequently 'everybody is talking about it. ${ }^{88}$ Elwyn Owen, a Minister at the Congregational Church of Lima, Ohio, hosted a screening of Peace Corps in Tanganyika in November 1962. He was certain that 'the young people who saw the 
picture will be "witnesses" for the eff ctiveness of the Peace Corps and that they will speak a good word for it wherever they ae. ${ }^{89}$

A number of correspondents engaged directly with Peace Corps publicity, confi ming its personal impact as well as extensive reach. Theirletters suggest a receptive audience for publicity material. However, some thought that the involvement of corporate advertising and popular entertainment degraded the Peace Corps. In early March 1961, to give one example, Georgian John Kirby sent a telegram to inquile if it was necessary 'the PC be corrupted' by appearing on the panel game show What's My Line? A few astute correspondents refl cted on the bias they perceived in Peace Corps publicity. Katherine Stone Philipp of New York phoned Sargent Shriver after watching a television programme about the Peace Corps in early December 1961. Shriver's secretary took notes, thus making this otherwise ephemeral interchange between Peace Corps HQ and a member of the public accessible. In Stone Philipp's view, the Peace Corps mystique was unhelpful: there was ' [too] much emphasis in the TV program on what a rather patronizing and not too popular Uncle Sam could show the rest of the world. In particular, she was critical of the fact that the locals who were hosting Peace Corps volunteers 'seemed not to have a chance to say a word' in the TV programme. In her view, Americans 'could make more friends' if they approached the world in a spirit of mutualexchange, rather than creating a fetish object of the Beautiful American. ${ }^{90}$

\section{Conclusion}

From its launchin early 1961, the Peace Corps drew upon a small army of publicists, advertisers and public relation experts. Together, they curated an image that emphasised the good intentions and humanitarian motives of American volunteers, portraying Peace Corps volunteers as embodiments of the Beautiful American both literally and allegorically. The intense focus on the volunteers served to elide detail about the places they would go and the work they would do, let alone the eff ctiveness of their effo ts. It also obscured the broader political and ideological contexts of international development. Rather than providing public infomation about US aid policy, or educating constituents about international development, the Peace Corps' publicity machine, fin ly tuned to the glamourof Hollywood and Madison Avenue, set about constructing a Peace Corps mystique.

The Peace Corps mystique was transmitted in voluminouspublicity material. Intense media coverage, much of which reproduced the images and concerns of official publicity, furthered the reach of this mystique. Moreover, the Peace Corps entered the realm of popular culture. Th oughout the 1960s and beyond, the Peace Corps became shorthand for a certain type of virtuousand principled American; in the 1987 film Dirty Dancing, set in 1963, the idealistic Baby was set to join the Peace Corps before she mæ Johnny. 
ThePeace Corps was extremely unusual in drawing the attention of the American public to international development. Public opinion polling, as well as the tens of thousands of letters, telegrams and phonecalls received by Shriver, confi $m$ that the Peace Corps captured the public's imagination. Thin ing about the Peace Corps spurred many people to consider the system of international development for the fi st time, and indeed many were confused about the nature, defini ion and location of underdevelopment. In this, many people's views accorded with the image presented by Peace Corps publicity and the media. Like the publicity material, the vast majority of letters focused on volunteers' altruistic intentions rather than their actions or eff ctiveness.

Imaging the Peace Corps in this way had further ramific tions. By presenting US intervention as a positive expression of American altruism, the Peace Corps popularised the view that America had a moral mandate, if not an obligation, to intervene in the underdeveloped nations of the world (even if the precise locations of underdevelopment were not clear). By reaching a broad audience, privileging American viewpoints, and eliding competing visions and critical appraisals, Peace Corps publicity helped normalise and glamorise thelogic of intervention embedded in the glbal system of international development.

\section{Notes}

1 G. Gallup, 'American "Peace Corps” Proposal Wins Broad Approval from Public', Washington Post (1 February 1961),p. 2.

2 N. Cullather, The Hungry World: America's Cold War Battle Against Poverty in Asia (Cambridge, MA: Harvard University Press, 2010), p. 642.

3 See G. Rist, The History of Development: From Western Origins to Global Faith (London and New York: Zed Books, 2008); B. Simpson, Economists with Guns: Authoritarian Development and US-Indonesian Relations, 1960-1968 (Stanford: Stanford University Press, 2008); Cullather, The Hungry World; M. Latham, The Right Kind of Revolution: Modernization, Development and US Foreign Policy from the Cold War to the Present (Ithaca: Cornell University Press, 2010); D. Ekbladh, The Great American Mission: Modernization and the Construction of an American World Order (Princeton: Princeton University Press, 2011).

4 A. Bocking-Welch, 'Imperial Legacies and Internationalist Discourses: British Involvement in the United Nations Freedom from Hunger Campaign, 1960-70', Journal of Imperial and Commonwealth History, 40:5(2012), pp. 879-96; K. O'Sullivan, 'HumanitarianEncounters: Biafra, NGOs and Imaginings of the Thi d World in Britain and Ireland, 1967-1970, Journal of Genocide Research, 16:2 (2014), pp 299-315.

5 R. Textor, Cultural Frontiers of the Peace Corps (Cambridge, MA: MIT Press, 1966), p. 3.

6 E. Cobbs Hoffman, All You Need is Love: The Peace Corps and the Spirit of the 1960s (Cambridge, MA: Harvard University Press, 1998), p. 1.

7 M. Geidel, Peace Corps Fantasies: How Development Shaped the Global Sixties (Minneapolis: University of Minnesota Press, 2015).

8 H. E. Salisbury, 'Kennedy Favors US "Peace Corps" to Work Abroad', New York Times (3 November 1960), p. 1.

9 Cobbs Hoffman, All You Need is Love, p. 3. 
10 Bill Moyers to Sargent Shriver, 27 February 1961, Incoming Mail Briefs 1961-1963, NND988052, Box 3, RG 49o: National Archives at College Park, MD (henceforth NARA)

11 E. Rosenberg, Spreading the American Dream: American Economic and Cultural Expansion, 1890-1945 (New York: Hill \& Wang, 1982); L. Belmonte, Selling the American Way: U.S. Propaganda and the Cold War (Philadelphia: University of Pennsylvania Press, 2008).

12 Terry Turner to Martha Crane, 28 September 1966, Radio and TelevisionFiles, NN3-490-00001, Box 1; Records of the Reace Corps, RG 49o: NARA.

13 Modern Talking Picture Service, What Do Audiences Say About Your Film? The Peace Corps in Tanganyika, Radio and Television Fles, Box 4.

14 Textor, Cultural Frontiers of the Peace Corps, p. 3.

15 Edward J. Flynn to Mr. Shriver, cc The resident, 29 March 1961, Incoming Mail Briefs, Box 1.

16 Eric Fleming andClint Eastwood to ThePresident, 29 March 1961, Incoming Mail Briefs, Box 1

17 Cobbs Hoffman, All You Need is Love, p. 1.

18 Cited in R Hoopes, The Complete Peace Corps Guide (New York: The Dial Press, 1961),p. 1.

19 Geidel, Peace Corps Fantasies.

20 O. Westad, The Global Cold War: Third World Interventions and the Making of Our Times (Cambridge: Cambridge University Press, 2007).

21 Michael Abbott, 'The eace Corps', Radio and Television Files, Box 4.

22 Peace Corps Fact Book (Washington, DC: Peace Corps, 061),p. 3.

23 Script, 'General one-minute radio spot\#3', Doherty, Cliffo d, Steers \& Shenfi ld, Inc for Peace Corps, February 1962, Radio and Television Files, Box 1.

24 Hoopes, The Complete Peace Corps Guide, p. 50.

25 G. Kittl r, The Peace Corps (New York: Paperback Library, 1963).

26 Geidel, Peace Corps Fantasies.

27 R. Hoopes, The Peace Corps Experience (New York: Clarkson N Potter Inc., 1968), pp. 113-17.

28 N. Cullather, 'Development? It's History', Diplomatic History, 24:2 (2000), p. 641.

29 First Annual Peace Corps Report (Washington, DC: Peace Corps, 962), pp 4-5.

30 Rist, The History of Development, pp. 75-6.

31 Reproduced in P. Madow, The Peace Corps (New York: H. H. Wilson Company, 1964), pp. 81-5.

32 First Annual Peace Corps Report, p. 58.

33 Hilda Cole Espy, 'What You Should Know About the Peace Corps', Atlantic Monthly, August 1962, in Rublic Relations Publications, NN3-490-95-001, Box 2, RG 49o: NARA.

34 Cited in Textor, Cultural Frontiers of the Peace Corps, p. 23.

35 Espy, 'What You Should Know About the Peace Corps'.

36 Hoopes, The Complete Peace Corps Guide, p. 49; Kittl r, The Peace Corps, p. 11

37 'The eace Corps: Almost as Good as itsintentions', Time (5 July 063), pp 18-22.

38 J. A. Wechler, 'Peace Veteran', New York Post (10 December 1966), page unknown.

39 Cobbs Hoffman, All You Need is Love; Geidel, Peace Corps Fantasies.

40 Wechler, 'Peace Veteran'.

41 Cited in The eace Corps: Almost as Good as itsintentions'.

42 Cited in Textor, Cultural Frontiers of the Peace Corps, p. 52.

43 Cited in The eace Corps: Almost as Good as its intentions'.

44 Geidel, Peace Corps Fantasies.

45 J. Hampton, 'The Beautiful American', The National Observer (1 February 1971), page unknown.

46 Geidel, Peace Corps Fantasies, p. 83. 
47 See L. Spigel, Welcome to the Dreamhouse: Popular Media and Postwar Suburbs (Durham, NC and London: Duke University Press, 2001); J. MacDonald, One Nation Under Television: The Rise and Decline of Network TV (New York: Pantheon Bodks, 1990).

48 Westinghouse Broadcasting Company, Inc to President Kennedy, 10 March 1961, Radio and Television Files, Box 1.

49 A. Archerd, 'Just for Variety', Variety (26 October 1962), page unknown.

50 A. Archerd, 'Just for Variety', Variety (15 October 1962), page unknown.

51 Telegram, Daniel Mann and Ray Wagner to John Horton, Peace Corps, 27 October 1962, Radio and Television Files, Box 1.

52 Internal memo, Doug Kiker to Sargent Shriver, 22 October 1962, Radio and Television Files, Box 1

53 Internal memo, Doug Kiker to Sargent Shriver, 26 October 1962, Radio and Television Files, Box 1.

54 Internal memo, Bill Moyers to Sargent Shriver, 26 October 1962, Radio and Television Files, Box 1

55 Script: 'Patty and the Peace Corps', The Patty Duke Show, New YorkPublic Library, CTR 366E.

56 A. Escobar, Encountering Development: The Making and Unmaking of the Third World (Princeton: Princeton University Press, 1995).

57 A. Sobocinska, 'How to Win Friends and Influ nce Nations: The International History of Development Volunteering', Journal of Global History, 1:1 (2017), pp. 49-73.

58 B. Rottinghaus, " "Dear Mr. President”: The Institutionalisation and Politicization of Public Opinion Mail in the White House', Political Science Quarterly, 21:3 (D06), pp. 451-76.

59 Rottinghaus, “'Dear Mr. President”, p. 465.

60 'Communications Center is Hub of Actvity', Peace Corps Current (3 March 1970), p. 7.

61 James Pastena to Peace Corps, 7 March 1961, Incoming Mail Briefs, Box 1.

62 Walter Robb to Mr Shriver, 10 May 1961, Incoming Mail Briefs, Box 1.

63 Daggett arvey, Chicago, to Sargent Shriver, Incoming Mail Briefs, Box 1.

64 See, for example, Benny A. Gonzalezto Mr. Shriver, 12 June 1961; Kenneth N. Harlan, Jr., to Mr. Shriver, 1 August 1961;James Pastena to Peace Corps, 7 March 1961, Incoming Mail Briefs 1961-1963, Box 1

65 Henry M. Jackson to Mr. Shriver, 18 September 1961, Incoming Mail Briefs, Box 1.

66 Meredith J. Rogers to Mr. Shriver, 28 June 1961, Incoming Mail Briefs, Box 1; TimmieRogers to The President, 15 March 1961, Incoming Mail Briefs, Box 1;Harry L. Wilson to Mr. Shriver, 27 March 1962, Incoming Mail Briefs, Box 2; Rose Gelb Good to Mr. Shriver, 1October 1961, Incoming Mail Briefs, Box 1.

67 George R. Gish to Senator Alexander Wiley, 28 March 961, Incoming Mail Briefs, Box 1.

68 Leon A Jaris to Mr. Shriver, 31 May 1961, Incoming Mail Briefs, Box 1.

69 Anna L. Steiger to Mr. Moyers, B August 1962, Incoming Mail Briefs, Box 2.

70 Mary Jo Denja (Lincoln Junior High School) to Mr. Shriver, 3 June 1963, Incoming Mail Briefs, Box 2.

71 Group D, Fourth Grade, TheNew Lincoln School, to Mr. Shriver, 18 April 1963; H. Alan Th ran (The igh School, Brookline) to Mr. Shriver, 18 December 1962, Incoming Mail Briefs, Box 2.

72 Rev. Phillip J. Murphy to Mr. Shriver, 26 June 961, Incoming Mail Briefs, Box 1.

73 Hans Gott chalk (NYState English Council) to Mr. Shriver, 14September 1961, SymonGould (American Vegetarian Party) to Mr. Shriver, 27 March 1961, AP Heiner (American Society of Traffic \& ransportation) to Mr. Shriver, 18 May 1961, Incoming Mail Briefs, Box 1

74 Elliot Forbes to Mr. Shriver, 25 February 1961, Incoming Mail Briefs, Box 1. 
75 Blair O. Rogers to Mr. Shriver, 10 March 1961, Incoming Mail Briefs, Box 1.

76 Congresswoman Florence P. Dwyer to Mr. Shriver, 22 March 1962, Incoming Mail Briefs, Box 2.

77 Senator Warren G. Magnuson to Mr. Shriver, 6 August 1962, in hcoming Mail Briefs, Box 2.

78 Lindley Beckworth to Peace Corps, received 15 March 1961, Incoming Mail Briefs, Box 1 .

79 Senator Kenneth B. Keating to Mr. Shriver, 21 March 1962, Incoming Mail Briefs, Box 2.

80 Senator Tho as Kuchel to Peace Corps, B March 1961, Incoming Mail Briefs, Box 1.

81 Senator Karl E. Mundt to Mr. Shriver, 21 April 1961 (re: Europe); James H Robinson to Mr. Shriver (re: Germany), 12 June 1961; Senator Warren Magnuson to Peace Corps, 15 March 1961 (re: Hungary); William C. Cramer to Peace Corps, 14November 1961(re: Britain), Incoming Mail Briefs, Box 1.

82 Egon W. Mueller to Mr. President, 28 July 961, Incoming Mail Briefs, Box 1.

83 Senator Spessard L. Holland to Mr. Shriver, 8 A ugust 1963, Incoming Mail Briefs, Box 2.

84 William J. Green to Mr. Shriver, B July 962, Incoming Mail Briefs, Box 2.

85 Senator Norris Cotton to Mr. Shriver, 6 May 1963, Incoming Mail Briefs, Box 2.

86 Laurence S. Moore to Mr. Shriver, received 29 June 961, Incoming Mail Briefs, Box 1

87 Congressman William C. Cramer to Mr. Shriver, 28 May 1963, Incoming Mail Briefs, Box 2.

88 Th odore Hesburg to Sargent Shriver, 20 March 1961, Incoming Mail Briefs, Box 1.

89 Rev. Elwyn Owen to Robert Ruben, Peace Corps, 5 November 1962, Radio and Television Files, Box 4.

90 Philipp, Katherine Stone, NY, NY to Mr Shriver (telephone), 12 December 1961, Incoming Mail Briefs, Box 1.

\section{References}

Archerd, A., 'Just for Variety', Variety (15 October 1962), page unknown.

Archerd, A., 'Just for Variety', Variety (26 October 1962), page unknown.

Belmonte, L., Selling the American Way: U.S. Propaganda and the Cold War (Philadelphia: University of Pennsylvania Press, 2008).

Bocking-Welch, A., 'Imperial Legacies and Internationalist Discourses: British Involvement in the United Nations Freedom from Hunger Campaign, 1960-70, Journal of Imperial and Commonwealth History, 40:5 (2012), pp 879-96.

Cobbs Hoffman, E., All You Need is Love: The Peace Corps and the Spirit of the 1960 (Cambridge, MA: Harvard University Press, 1998).

'Communications Center is Hub of Actvity', Peace Corps Current (3 March 1970), p. 7.

Cullather, N., 'Development? It's History', Diplomatic History, 24:2 (2000), pp. 641-53.

Cullather, N., The Hungry World: America's Cold War Battle Against Poverty in Asia (Cambridge, MA: Harvard University Press, 2010).

Ekbladh, D., The Great American Mission: Modernization and the Construction of an American World Order (Princeton: Princeton University Press, 2011).

Escobar, A., Encountering Development: The Making and Unmaking of the Third World (Princeton: Princeton University Press, 1995).

First Annual Peace Corps Report (Washington, DC: Peace Corps, 1962).

Gallup, G., 'American “Peace Corps” Proposal Wins Broad Approval from Public', Washington Post (1 February 1961),p. 2.

Geidel, M., Peace Corps Fantasies: How Development Shaped the Global Sixties (Minneapolis: University of Minnesota Press, 2015).

Hampton, J., 'The B autiful American', The National Observer (1 February 1971), pge unknown. 
Hoopes, R., The Complete Peace Corps Guide (New York: The Dial Press, 1961).

Hoopes, R., The Peace Corps Experience (New York: Clarkson N. Potter Inc., 1968).

Kittl r, G., The Peace Corps (New York: Paperback Library, 1963).

Latham, M., The Right Kind of Revolution: Modernization, Development and US Foreign Policy from the Cold War to the Present (Ithaca: Cornell University Press, 2010).

MacDonald, J., One Nation Under Television: The Rise and Decline of Network TV (New York: Pantheon Books, 1990).

Madow, P., The Peace Corps (New York: H. H. Wilson Company, 1964).

O'Sullivan, K., 'Humanitarian Encounters: Biafra, NGOs and Imaginings of the Thi d World in Britain and Ireland, 1967-1970, Journal of Genocide Research, 16:2 (2014), pp 299-315.

'The eace Corps: Almost as Good as itsintentions', Time (5 July 963), pp 18-22.

Peace Corps Fact Book (Washington, DC: Peace Corps, 1961).

Rist, G., The History of Development: From Western Origins to Global Faith (Londonand New York: Zed Books, 2008).

Rosenberg, E., Spreading the American Dream: American Economic and Cultural Expansion, 189o1945 (New York: Hill \& Wang, 1982).

Rottinghaus, B., "'Dear Mr. President”: The Institutionalisation and Politicization of Public Opinion Mail in the White House', Political Science Quarterly, 21:3 (2006), pp. 451-76.

Salisbury, H. E., 'Kennedy Favors US "Peace Corps" to Work Abroad', New York Times (3 November 960$)$, p. 1.

Simpson, B., Economists with Guns: Authoritarian Development and US-Indonesian Relations, 19601968 (Stanford: Stanford University Press, 2008).

Sobocinska, A., 'How to Win Friends and Influ nce Nations: The International History of Development Volunteering', Journal of Global History, R:1 (2017), pp. 49-73.

Spigel, L., Welcome to the Dreamhouse: Popular Media and Postwar Suburbs (Durham, NC and London: Duke University Press, 2001).

Textor, R., Cultural Frontiers of the Peace Corps (Cambridge, MA: MIT Press, 1966).

Wechler, J. A., 'Peace Veteran', New York Post (10 December 1966), page unknown.

Westad, O., The Global Cold War: Third World Interventions and the Making of Our Times (Cambridge: Cambridge University Press, 2007). 



\section{Part II}

Narratives of humanitarianism 



\title{
4 \\ The naive republic of aid: Grassroots exceptionalism in humanitarian memoir
}

\author{
Emily Bauman
}

Memoir has for some time played a signific nt role in the expansion and interpretation of the humanitarian industry. It was Henri Dunant's 1862 memoir $A$ Memory of Solferino that made the case for the fi st global institutionalisation of humanitarian work in the ICRC (International Committee of the Red Cross) and Geneva Convention, and Moritz Tho sen's 1969 memoir Living Poor: A Peace Corps Chronicle that helped promote participation in the US Peace Corps. ${ }^{1}$ As the industry has become entrenched as a third player permanently integrated into global relations, humanitarian memoir has becomea fast-growing genre. For both the relief and development industries memoir is admirably suited as an ambassador from the fi ld to the larger public, oriented as it is to personal experience and testimony. The genre helps build awareness of humanitarian effo ts and issues and facilitates the translation of professional work to popular understanding; most important, as a medium whose defini g posture is confessional and revelatory, humanitarian memoir generates an aura of authenticity much needed by an industry reliant on public donations and on the perception of its status as a player outsidethe systems of state sovereignty and global capital.

Unlike other forms of humanitarian narrative, which are focused on humanitarian crises and projects or on the work of a particular organisation, humanitarian life-writing tells a story of individual education and empowerment. As a result the genre's emphasis is not the typical one of compassion and pathos, though images of human suff ring may be highlighted. Instead, humanity is defin d intellectually as a pure intelligence and understanding that operates outside of established systems of knowledge production, separated from corporate and bureaucratic hegemony. In humanitarian memoir the prototypical humanitarian is the naive who confronts injustice with instinct; naivety and even foolishness are presented as the hallmark of the humanitarian agent and the ultimate sources of his or her power. The memoirbased humanitarian speaks to a broad public alienation from a rising culture of expertise and from 'big' management more generally. Since the end of the Cold War, 
as aid has increasingly been channelled through mega NGOs who take on the roles of state actors, appetite for stories about the naive exceptionality of the humanitarian industry has begun to findits voice. Paradoxically, this figure has come most to life just as humanitarianism has become more professionalised, assuring readers that the face of this global multi-billion dollar industry is still predicated on the spontaneous ingenuousness and ingenuity of the rogue actor bucking the system in order to eff ct social change. ${ }^{2}$

As the aid world has expanded to serve its benefi iaries in mass capacity, confronting greater exigencies of service delivery, accountability and public relations, its discourse and biographies have become increasingly planned, standardised and scientifi . Originally consisting of a few small emergency-driven charity groups in thefi sthalf of the twentieth century, thehumanitarian industry has since the Second World War become increasingly centralized and bureaucratized', a necessary result of the secularisation of an industry increasingly shaped by states and internationalist development economists. ${ }^{3}$ Thehallmark of this approach is 'planning-mindedness', an orientation that sees humanitarian work less as a simple response to immediate need than as a complex operation casting the long view across an unevenly developed world, looking towards progress and modernisation. ${ }^{4}$ During the decades following the end of the Second World War, the turn to planning and rationalisation created important overlap between relief and development, especially as operations globalised. It was this era that saw the rise of the humanitarian 'kit', a prepackaged assembly of tools designed to help expand a particular development project or type of emergency action by standardising it. ${ }^{5}$ During the 1990 s, when the humanitarian industry expanded again with the collapse of the Cold War and retreat of the welfare state, humanitarian organisations began to grapple with issues of accountability, mostly to donors who expected not just fi ancial transparency but impact assessment. Organisations introduced camp surveys; developed performance indicators; and created new methodologies and instruments that can better assess eff ctiveness.' Amongst these instruments was the logical framework approach (LFA), a planning and evaluating tool adapted by USAID and eventually the aid world from the US military and NASA. ${ }^{7}$ A staple of results based management based on the application of 'basic scientific methods', log frames have been controversial due to their technocratic, mechanistic approach. ${ }^{8}$ The widespread use of the LFA also refl cts the growth of professional development training in the past couple of decades, especially of degree programmes oriented towards a career in international relief or development. ${ }^{9}$ A recent article in Forbes magazine has described a master's degree in an appropriate (usually social sciences-based) fi ld as a 'must' for the aspiring international aid worker, a reality confi med by job postings and surveys amongst professionals in the fild. ${ }^{10}$

Professionally, then, the face that humanitarianism is increasingly putting forward is one that mixes managerial culture, scientisation and institutional training. Ths rationalisation of the humanitarian endeavor reinforces and extends 
to aid worker subjectivity the phenomenon that Didier Fassin has called 'humanitarian reason' - the adminstrative judgement and discourse by which the humanitarian conglomerate governs those who come under its wing. ${ }^{11}$ As we shall see, humanitarian memoir provides a counter-discourse to this phenomenon. For the aid industry's appeal to the public generally relies on the allure of individuas living outside the system, thinking outside the system, and experiencing the world nonsystematically. Even as humanitarian authority presupposes structured reasoning and methodical organisation, its mandate is still viewed through the lens of personal impuke and independence. Improvising in the midst of chaos, testing the limits of one's endurance and ingenuity, following gut instinct even or especially when it flouts the rules: these are the core stories that acquaint the industry with its (potentially participant/ donor) reading audience. Where the humanitarian order is working towards wider consensus, industry narrative relies on and cultivates what I would call the sovereign irrational: an ideal of individual, intuitive integrity seen as the fundamental component of what it means to be human. Ths vision of the human undergirds, contradicts, but ultimately legitimates the elaborate web of humanitarian power that is now part of the new world order. It is nowhere more evident than in memoir - a genre that already celebrates the revelation of pure individuality as an agent of change within the satusquo.

Th s chapter examines memoirs by 'humanitarians', that is, workers in nongovernmental or intergovernmental institutions devoted to promoting the welfare of others. I excludememoirs by aid recipients or survivors, such as the signific nt body of life-writing by members of the Lost Boys of Sudan, as these follow their own rules and logic. An emerging genre (most titles date from the new millennium), humanitarian-worker memoir nevertheless may already be divided into subgenres. Surprisingly these do not necessarily fall into the 'relief' versus 'development' categories that have forso long divided the aid industry itself. Rather, the genre tends to divide amongst aid worker memoirs of individuals who document theirexperiences serving in one or more humanitarian organisations, and memoirs of individuals (often well-known in the industry, or Nobel Peace Prize-winners or nomines) who have themselves founded a humanitarian organisation or served a leading role withinit. The fi st category includes Peace Corps memoirs, memoirs of career professionals, and 'gap year' volunteer memoirs. Th se books are often coming-ofage, 'rite of passage' narratives that move the subject from naivety to thoughtfulness or cynicism; even while some end with disillusionment and criticism of the aid industry, they usually continue to affirm the writer's original values and vision in some rediscovered form. ${ }^{12}$ The founder narratives - whether autobiography or biography - tend to be more analytical, focused on problem-solving and building support in order to counter entrenched opposition or inertia. In both subgenres the role of the 'fool' in a larger sea of institutional limitations proves both revelatory and empowering, asserting the value of sui generis intelligence to produce humanitarian knowledge and even participate in gldal governance. 
In this chapter I concentrate on founder memoirs in the fi ld of humanitarian international development. I look at founder memoirs because there is more at stake in theirneed to legitimise the organisation whose founding they describe; as a result theirperspectives speakmore directly to humanitarianideology. Thenaive is also perhaps more surprising and provocative in this subgenre, where in aid worker memoirs the reader expects the stories to be about a novice confronting the fi ld andlearning from the outside My aim is not to give a comprehensive genre analysis; instead I look at two case studies that represent distinct forms of the humanitarian naive at work. Greg Mortenson and David Oliver Relin's 2006 award-winning but controversial Three Cups of Tea is one of the bestselling humanitarian founder memoirs of all time, spending 220 weeks on the New York Times bestseller list. ${ }^{13}$ Muhammad Yunus's 1999 Banker to the Poor: Micro-Lending and the Battle Against World Poverty gives a genesis story of one of the most influ ntial recent reconfigurations of aid provision, microfi ance. As development memoirs, both illuminate the impact international development has had on the humanitarian fi ld and reveal a core tension between humanitarian narrative and humanitarian institutionalisation, where what might be called the fi ld's aesthetic runs up against its gowing foms of power.

\section{Naive ontologies: the misfit abroad}

Humanitarian founder narratives build on the precedent of classic aid worker memoir: the protagonists arrive knowing very little about their host countries or aid work - yet their naivety is fruitful. Even as they learn the ropes they learn that there are no ropes, that all good paths must be self-generated. ${ }^{14}$ But while aid worker memoir tends to view the humanitarian international as part of the larger global order, for founder narratives humanitarianism is still a third sector capable of acting from outside Thus unlike aid memoir, where worker contributions may follow an individual logic but only as exceptional drops in a larger institutional bucket, founder memoirs show theirheroes generating lasting outcomes based on following their own instincts and personal calling.

One of the best places to begin a discussion of humanitarian founder memoir is with Mortenson and Relin's Three Cups of Tea. It is the story of the unorthodox founder of the Central Asia Institute (CAI), mountaineer-turned-humanitarian Greg Mortenson, and his effo ts to build schools across underserved and often remote areas of Pakistan and Afghanistan. The book begins with Mortenson (referred to in the third person throughout) lost in Pakistan's Baltistani mountains near K2 and accidentally discovering the town of Korphe, where after being nursed to health he discovers that the town children have no school and determines to build one for them. It is a conversion narrative of sorts, ultimately transforming Mortenson, an emergency room nurse, into the founder of a global education nonprofit. His shift from medical to education industries mirors the rising transition in post-war humanitarianism from relief to development (notably before he became a 
medical worker Mortenson was in the military - the other forebear of emergency humanitarianism), while at the same time rejecting development's rationalised and deliberative ethos. One school leads to another as Mortenson becomes more embedded in local relationships and develops a closer understanding of the community and its needs. His accidental entry into school building in Pakistan and Afghanistan becomes a lifelong mission. In interview, Mortenson has said of CAI's growth: 'Th re was no initial plan', and throughout the memoir, Mortenson's story demonstrates the inferiority of planning as a form of humanitarian knowledge and agency. ${ }^{15} \mathrm{He}$ works intuitively, for instance hiring CAI's staff - a cast of unusual and even 'unsavory' characters - based on 'gut feelings' rather than resumé, producing 'what has to be one of the most underqualifi d and overachieving staffs of any charitable organization on earth. ${ }^{16}$ Mortenson's success, the book maintains, is a result of a spontaneous, grassroots approach that has allowed him to maintain his initial novice-like energy and ingenuity. Unlike in a bildungsroman, his initial naivety does not become worldliness; rather even as CAI expands Mortenson remains 'foolish' to the ways of the international development complex, setting his own course in the mountains of central Asia.

Three Cups portrays its hero as a return to the early humanitarian ideal - beginning with Dunant - of the lone pioneer independently improvising solutions in a broken system without any formal training. Thelocals, we are told, call Mortenson 'Dr Greg', even though he has no MD or PhD. Mortenson's self-taught autonomy is represented in Relin's introduction when we see him heroically guiding a local pilot to land in the mountainous territory. Brigadier General Bhangoo is 'one of Pakistan's most experienced high-altitude helicopter pilots', yet he almost imperils everyone on the plane when he gets lost $\mathrm{fl}$ ing over terrain Mortenson has come to know - literally - on the ground. 'How is it you know the terrain better than me?' the pilot asks, later dubbing him 'the most remarkable person I've ever met' (1-3). Mortenson's self-taught expertise is celebrated later in the book by Representative Mary Bono after she has become acquainted with his knowledge of Muslim culture in Pakistan: " I have to tell you I learned more from you in the last hour than I have in all the briefi gs I've been to on capitol Hill since 9/11. We've got to get you up there"' (280-1). Humanitarian knowledge comes from lived experience and 'winging it', not training or expertise, the book suggests (4). Mortenson's credibility as local guide and development pioneer also requires that we see him as a student of the culture, though one who pointedly learns outside of a classroom. His alternative 'schooling' is epitomised in the scene where, after driving all of his workers crazy as taskmaster, he is deprived of his tools and lectured by Korphe's village chief Haji Ali on the need to take time for 'three cups of tea' - a counter-vision of development work that Mortenson commitshimself to as apprentice. The book quotes Mortenson as saying that this moment taught him the most important lesson of his life, that 'I had more to learn from the people I work with than I could ever hope to teach them' (150). A second time Ali lectures Mortenson, following an apocryphal 
scene where he is kidnapped by the Taliban, and a second time Mortenson says: 'So once again, an illiterate old Balti taught a Westerner how to best go about developing his "backward" area' (177).

Dwelling on the role-reversal of foreign 'expert' and local representative is a standard trope in aid memoir. It allows the aid worker to adopt a pose of humility while claiming exception to Western arrogance and appearing to make a naive intervention in commonsense development attitudes (apparently unaware that this 'intervention' is already a commonpace in international development). Th quotes above serve a further function of magnifying Mortenson's role as novitiate of the local culture and its organic humanitarian knowledge, whose mastery he demonstrates by educating his readers about it. The Balti culture is represented in the book as itself a bearer of naive knowledge, outsidethe paradigms of modernity. Indeed, Mortenson is often quoted emphasising the danger of imposing 'modern' values and mechanisms on a people who 'still held the key to a kind of uncomplicated happiness that was disappearing in the developing worldas fast as old-growth forests' (120). Such statements help the book frame its mission to a liberal audience eager to sympathise with a non threatening Islamic 'other'. By aiding a people who are seen to maintain a pre-modern worldview and (unlike al Qaeda) are not technologically sophisticated, donating to CAI can be embraced as a peaceful, non-Islamophobic contribution to the war on terror, it was in fact required reading amongst US military officers during reconstruction in Afghanistan. ${ }^{17}$ In a post-2001 context, building schools (with culturally appropriate but non-extremist education), the memoir insists, is the best way to counter the power of the Wahhabi madrassas fuelling the rise of radical Islamic extremism (241-5). By the end of the book Mortenson has become a 'doctor' of peace and human rights as well as humanitarian development, a position he has earned through his non-traditional education in thefi ld.

If Mortenson is the ideal development visionary, able to act as bridge between cultures and even (the book suggests) temporalities, it is because like many aid workers he is presented as being 'diff rent' from other Westerners. He lives out of a storage locker, doesn't wear socks to a fancy event (where the guest of honouris Sir Edmund Hillary), keeps a list of potential celebrity-donors in a ziploc bag, and writes out his fi st batch of letters to Congressmen appealing for funds on outdated technology. "I had no idea what I was doing", Mortenson remembers. "I just kept a list of everyone who seemed powerful or popular or important and typed them a letter. I was thirty-six years old and I didn't even know how to use a computer. That's how clueless I was"' (50). Most telling, Mortenson doesn't wear a watch $(24) .{ }^{18} \mathrm{He}$ is, we are told twice, living on 'African time', a behaviourtrait left over from growing up in Tanzania. "'Greg has never been on time in his life", his mother says. "Ever since he was a boy, Greg has always operated on African time"' (39). Mortenson's mother-in law goes one step further, portraying him as a prehistoric but sublime 'other' living beyond the boundry of avilisation: 
'I had to admit Tara was right, there was something to this "Mr Wonderful" stuff', Lila says. And like her daughter, she had come to the conclusionthat the large, gentle man living two blocks away was cut from unusual cloth. 'One snowy night we were barbecuing, and I asked Greg to go out and turn the salmon', Lila says. 'I looked out the patio door a moment later and saw Greg, standing barefoot in the snow, scooping up the fish with a shovel, and flipping it, like that was the most normal thing in the world. And I guess, to him, it was. That's when I realized that he's just not one of us. He's his own species.' (238)

Th oughout, Three Cups develops the above image of Mortenson as a savage mind challenger to Western decadence and technology, naturally primed to findhis abilities best realised in 'developing world' or indigenous contexts. Ths reinforces the reader's trust in him as a maverick figure who can see and act beyond managerial or technical paradigms, a portrayal that is brought out in the memoir's language. During the story of Mortenson losing his way on the mountainwe see himwaking up after having fallen asleep on the way down, lost, exposed to the elements, separated from his climbing buddy. 'He untangled his hands from the blanket's tight cocoon with nightmarish inefficiency' (17). TheYoung Reader's version of Three Cups of Tea elaborates on the 'African time' quote by explaining that after he moved to the United States, 'Greg never adjusted to the kind of scheduled life that most Americans think of as normal. ${ }^{19}$ In other words, Mortenson's inefficient, unscheduled habits are not those typically valued by the business world, making him a fi ing counterpoint to the professionalised culture that has come to dominate 'big' humanitarianism.

The memoir develops - seemingly purposefully - the image of its hero as an unlikely candidate to manage an international organisation. Th s is most apparent when it comes to fi ances. Mortenson's often flailing attempts to get cash are part of his anti-materialist appeal, and the memoir gains much traction from this counterpoint as it moves agilely between his workin Baltistan and his fundraising effo ts back in the States. Sandwiched in between descriptions of an uplift water scheme to help Kashmiri refugees in northern Pakistan and a visit to pay respects to the exposed corpse of Mother Teresa in Calcutta, we find Mortenson's trip to Atlanta to meet with a potential donor, the elderly widow picks him up in a car filled with tin cans, arranges a massage for him in her living room, and in the midde of the night wanders into his bedroom half-naked, in the end giving nothing to the organisation. Stories like these of Mortenson's gullibility at homeare eff ctive foils to his openness and curiosity in the fi ld, his clumsy fi anciering separating himfrom the profi -driven worldliness to which the non-profit industry pleads exception. As a kind of 'fool' Mortenson off rs readers (who are also potential donors) a resolution to the ethicaltensioninherent in the industry between altruism and commercialism, giving and selling. After the memoir's publication the press celebrated the (re)emergence of a non-corporate humanitarianism: '[Mortenson's] organisation has no fancy offices or fl et of Land Cruisers like most aid agencies or non-governmental organisations. ${ }^{\text {'20 }}$ Three Cups seemed to promise that a personality-driven, homemade 
humanitarianism would preserve the industry's integrity by reducing its business to a single indvidual sripped of al business-like qualities.

Indeed, Three Cups appears to celebrate its hero's self-described 'cluelessness' and even seeming incompetence. The book includes, for instance, the story of how Mortenson, as executive director of CAI, frustrates members of the organisation's board of directors because he doesn't delegate or set boundaries. Tom Vaughan, the former director of the board, explains Mortensons's freewheeling approach: 'The board had a discussionabout trying to make Greg account forhow he spent his time, but we realized that would never work. Greg just does whatever he wants' (229). Vaughan's quote may seem severe, but in the context of the memoir his admission merely affirms the humanitarian basis of its hero's success story and his sovereignty as a 'separate species'; Mortenson's unaccountable methods serve to distinguish him from something as corporate-sounding as a board. Rather than being a form of powerlessness, his fi ancial naivety appears to demonstrate his fitn ss for the fi ld and his exceptionality as a humanitarian worker.

Theirony that history would reveal, of course, is that going rogue when it comes to fi ancial management does not necessarily spell humanitarian redemption. Less than fi e years after the book's publication scandal broke, a scandal that halted its bestseller streak and was followed months later by Relin's suicide. In April of 2011 Sixty Minutes revealed that some of the stories were fic ionalised (the introductory narrative aboutgetting lost and fin ing Korphe and, most luridly, of being kidnapped and released by the Taliban) and that CAI funds were being spent disproportionately on private jet $\mathrm{PR}$ rather than education. Th $\mathrm{n}$ Jon Krakauer, a former donor to CAI, published a lengthy exposé of Mortenson's mismanagement of CAI funds, in particular funds used to promote Three Cups of Tea, and of the number of schools he claimed to have built. ${ }^{21}$ Interpreting these revelations, Peter Hessler questioned the 'mom and pop' quality of Mortenson's school-building effo ts, suggesting that his organisation had become an expansionist machine that no longer thought and acted at the local, human level. Mortenson, he wrote, 'believes in scale, speed, and the constant need for more moneyand more construction. ${ }^{22}$ Hessler's image of CAI as top-down and quantitatively obsessed contrasts with its image painted early on in the media and in the book, a contradiction that illumimates some of the potential consequences latent in aid memoir's 'amateur founder' ideal. Penguin's promotional quotes and high-school-age studyguideproclaimthat CAI's story is about the power of a single individual, giving voice to a desire latent in the humanitarian unconscious that the humanitarian agent shouldsubsume the humanitarian organisation; what the fallout of the scandal suggests is what can happen when this actually takes place. ${ }^{23}$ 'Thefact is the CAI is Greg', Tom Vaughan is quoted as saying in the memoir (230). For the reading public this statement articulates a deep assumption about the aid industry that, unlike other institutions, it should still be 'human' and preserve human-scale governance within the larger global order. The naive exceptionalism that helped to build Mortenson's star power seemed to guarantee this humanity; 
at the same time the radical freedom it sanctioned may have laid the ground for corruption and abuse.

Thequestion of accountability was, as we have seen, one of the motivators behind the rationalisation of the humanitarian industry. At the same time this rationalisation has also frustrated aid accountability. In the face of aid world corruption scandals and charges of one-size-fit -all obliviousness, Three Cups returns us to the 'small is beautiful' equation of the humanitarian project with human personality and biography, where individualcharacter transcends and supersedes rational planning. Perhaps it is for this reason that every single summary or description of Mortenson's work dutifully begins with the story of his failing to summitK2 before getting lost and fin ing Korphe, as though building schools was really the mountain he had wanted to climb all along, only he didn't know it. The memoir's hero has stumbled into international development, into the war on terror, into his position of power. If a reader had any questions about whether - as is so often said of the aid industry the road to hell is paved with good intentions, a backstory grounded in the naive absence of intention might go a long way towards assuaging them.

\section{Naive epistemologies: in search of the simple}

As portrayed in Three Cups of Tea, Greg Mortenson was the ultimate anti-professional humanitarian hero, the founder of an international education NGO who had no expertise in education, international development or public management. But many founder narratives are written by or about professionals, even experts, in their given fi lds. ${ }^{24}$ Th se narratives use the naive diff rently - less to represent an outsideculture and the aid worker's belonging in it than to reveal an outside analytic that the aid worker has helped generate or discover. Tho gh highly trained, 'professional' founders often describe their foray into humanitarian work as a blank slate experience and their success as the result of their outsider perspective and embrace of an ingénue point of view. So, forinstance, even an expert in economics fin shimselfon fresh ground when he attempts to alleviate poverty via the world of banking.

The search for solutions to development problems since the height of the postwar era has tended to focus on 'modernising' poor countries, usually using Western systems and institutions as models. Ths has meant promoting technological makeovers, large-scale infrastructure projects and economicliberalisation. At the same time some of those with advanced training who are from developing countries have taken a diff rent approach, generating alternative ideas for how to structurally alter conditions of impoverishment, powerlessness and inequality. Perhaps the most famous of these is Muhammad Yunus, the founder of the Grameen Bank and one of the pioneers of microcredit banking. Yunus and the bank he founded earned the 2006 Nobel Peace prize for helping to create a new form of fi ancial services, oriented towards rural women in Bangladesh trapped in cycles of debt to predatory moneylenders because theycannotobtainbankloans. Since 1983 when the Grameen 
Bank was officially authorised by the Bangladeshi government (the same year that Acción International founded the fi st international network of microlending organisations in Latin America), microcredit has been widely embraced as the silver bullet of development economics. Despite recent criticisms, microfi ance (which includes microsavings and microinsurance as well as microcredit) remains a significant player on the global scene. ${ }^{25}$ Including non-profit and for-profit banks, NGOs, and other fi ancial structures, it is estimated to be a $\$ 60-100$ billionindustry serving 20 o million clients and is a key contributor to wider approaches that see the extension of fi ancial services to the rural pooras a necessary component of international development. ${ }^{26}$

Muhammad Yunus began to experiment with microlending in the mid-1970s, which is when his memoir, Banker to the Poor, begins. Banker to the Poor is a testament to how well narrative can function as an alternative textbook, teaching complex concepts through a step-by-step discovery process. Yunus allows plenty of time to explain the economics of the Bangladeshi borrowing system to his readers - he does not disavow his expertise. But he also takes the reader with him into a state of ignorance. The techniqueworks to transmit Yunus's ideas to a potentially nonexpert audience, while also building up his role (and hence that of his organisation) as interloper in the world of rural poverty alleviation. For Yunus this interloping is a discursive experience, one that returns again and again to an engagement with a single word. The memoir pointedly positions the problem of cyclical, intractable poverty against the question of the 'simple'. The simple grows throughout the opening pages, taking on a larger-than-life quality, as Yunus gets deeper into a world he has developed theories about but nerer trulyknown.

If there were a compendium of 'keywords' in humanitarian development memoir, the 'simple' would be a necessary inclusion As with Raymond Williams's keywords, the term is part of popular vocabulary but laden with cultural and social meanings that at once indicate and interpret experience. ${ }^{27}$ As we shall see, it is also a term whose successful appropriation endows the writer or speaker with a specific power: the power to authorise a particular type of action, especially in the context of a challenge to formal evaluative guidelines. Claiming 'the simple' reinforces the humanitarian desire to strip reality down to elemental, unequivocal truths in order to imagine deeds that are clear and unambivalent, and it reaffirms the belief that such work takes place outside of complicating superstructures. The term is used in this way, for instance, in environmentalist Wangari Maathai's founder memoir Unbowed, when she is coaching her team of rural Kenyan women how to plant trees in the early stages of the Green Belt movement. She does so against the advice of foresters who have told her 'You need people with diplomas to plant trees'. But, she realises, 'professionals can make simple things complicated'. ${ }^{28}$ In Banker to the Poor the quest for the simple emerges as a kind of unorthodox divination system. It becomes a way of exposing the false justific tion of business-as-usual and a way of discovering and naming the founding principle of a new kind of business: the seemingly impossible, 
paradoxical and contradictory business of humanitarian banking, of being a banker to the poor. As naive interrogator, Yunus exposes the illogic of the system, an illogic whose complexity can seemingly onlybe addressed by a systemic outside, by something that cuts through the maze of exploitation and circularity of poverty in rural Bangladesh.

But fi st he must become that interrogator. The action begins with Yunus, chair of the economics department at Chittagong University, disenchanted with the world he has trained to workin. It is 1974 , during the Bangladeshi famine, and the national response is crippled; religiousorganisations findthat even 'the simple act of collecting the dead' exceeds theircapacities. All that is left is mute communication. 'Thestarving people did not chant any slogans. Theydid not demand anything from us well-fed city folk. Theysimply lay down very quietly on our doorsteps and waited to die. ${ }^{29}$ Theeloquence of the simple - figured in the images of dying and collecting the dead - is at once statement and accusation, challenging Yunus to devise a way to meet it on its own terms. But his fi ld fails this test, lost in an abstract philosophy of knowledge-production that ignores the physicalreality that Yunus will later incorporate into his own theories.

I used to feel a thrill at teaching my students the elegant economictheories that could supposedly cure societal problems of all types. But in 1974, I started to dread my own lectures. What good were all my complex theories when people were dying of starvation on the sidewalks and porches across from my lecture hall? [...] Nothing in the economictheories I taught refl cted the life around me [...] I needed to run away from these theories and from my textbooks and discover the real-life economics of a poor person's existence. (viii)

So Yunus sets off to Jobra village, the town next to Chittagong where he teaches, to 'become a student all over again', to learn how to grasp the realities of everyday life outside of 'traditional book learning' (ix). Instead of the macro the micro will be his analyticallens, as it will eventually be the foundation of his humanitarian enterprise: naively shifting from universal, systems-based thinking to the point of view of the radical particular. In an echo of Mortenson's tutelage under Haji Ali, Yunus writes, 'The poor aught me an entirely new economics' (ix).

Yunus's fi st teacher is Sufiya Begum, one of many in a series of interviews he conductswith local women, ultra-low wage earners, behind a bamboo wall or curtain (since he is male and the custom of purdah requires it). In a widely cited story, he recounts learning that Begum's profit off of bamboo stools was only two cents a day since she lacked the twenty-two cents worth of capital needed to buy the raw bamboo materials herself instead of from the usurious trader. In sequence Yunus flirts with conventional aidresponses that seem 'so simple, so easy': giving Begumthe moneyoutright, loaning all the villagers their needed funds (twenty-seven dollars) interest-free. He rejects the fi st and tries the second, only to have moming-after 
regrets; these are simple responses, but not simple solutions (48-51). So he goes to persuade the bank, source of commercial lending rates to which middle and higher income people in developing countries have access, to issue a loan to the villagers. The lengthy debate that follows pivots on contradictory uses of the word 'simple', each seeking to claimits soul; on the side of the bank manager it signifi s the law of banking necessity and on the side of unus, humanitarian freedom.

Themanager begins with what he thinks is an unanswerable rhetorical question: how do you nu a bank with illiterate clients?

'Simple, the bank jus issues a receipt for the mount of cash that the bank receives'.

'What if the person wants to withdraw money?'

'I don't know ... there must be a simple way. The borrower comes back with his or her deposit receipt, presents it to the cashier, and the cashier gives back the money. Whatever accounting the bank does is the bank's business'. (53)

The branch manager is not convinced and tells him, 'Professor, banking is not as simple as you think', to which Yunus responds, 'banking is not as complicated as you make it out to be'. At this moment the word is seized by the manager himself: 'Look, the simple truth is that a borrower at any other bank in any place in the world would have to fill out forms.' Again he emphasises, 'we simply cannotlend to the destitute'. Yunus parries with the basicnaive question: 'Why not?', asking the status quo to reveal its own mandate (53). Themanager's answer unveils the core problem of banking for the poor: collateral, security against the risk of default. Yunus, as the voice of naive logic, states the dbvious: 'It's a sily rule. It means only the rch can borrow' (54).

It is one thing to know general principles about banking, another to sit in the chair as if you yourself were a group of poor women applying for a loan. Above Yunus confronts the rules of the bank experientially, placing himself in the role of the disenfranchised trying to get a loan and pushing irreverently until he hits the wall of a fi al cause. In the end it turns out that the branch manager doesn't even have the authority to grant loans (though he does eventually direct Yunus to the higher-ups); like a Monty Python sketch he is having fun with Professor Yunus, who is made a fool of even as he has played the fool in order to expose and challenge the unfaimess of the system.

Thepower of the fool is not so much to reveal or elicit particular infomation: that is the role of the sleuth or the investigator. It is rather to reveal the abstract realities and forces that create reality, itslaws, principles and governing modes. 'It had become clear from my discussions with bankers in the past few days that I was not up against the Janata Bank per se but against the banking system in general [...] Out of sheer frustration, I had questioned the most basic banking premise of collateral. I did not know if I was right. I had no idea what I was getting myself into. I was walking blind and learning as I went along' $(55,57)$. Once the premise of collateral has been challenged Yunus, still 'walking blind, tries diff rent strategies for replacing it, eventually hitting on the invention of group lending. Ths solution is directly heretical 
to the assumption that banking economics is an abstract system based on signs and representations, for Yunus's 'simple' intervention has been to reformulate the rationalised, abstract banking system as an intuitive, physicalone. 'My workbecame a struggle to show that the fi ancial untouchables are actually touchable, even huggable' (57). Demonstrating the 'touchability' of the banking untouchables is not only a caste allusion,but the very essence of Yunus's approach: to convert the impersonal, bureaucratic institution into human relationships He literally tells his workers to 'touch' theirclients in an effo t to understand theirperspective and 'mentality' $(81) .^{30}$ Intimate contact is further epitomised by the borrower 'support groups' whose 'peerpressure' he stresses will guarantee loan recovery in the absence of collateral (62). All of these relationships make 'human trust', not 'meaningless paper contracts', the basis of the loan-recovery procedure. 'Grameen would succeed or fail depending on the strength of our personal relationships We may be accused of being naive, but our experience with bad debt is less than 1 percent' (70). ${ }^{31}$ In Banker to the Poor, these relationships ppear to be the simpe governing logic of micofi ance.

The essence of microfi ance may be relationships, but in the end the institution still subscribes to the logic of individual accountability and autonomy that governs traditional banking. The implication that the 'naive' approach of microcredit constitutes a humanitarian intervention in commercial logic and economic inequality has been challenged on the grounds that it replicates neoliberal ideologies of individual entrepreneurship over state safety nets and sees market involvement as the solution to poverty. ${ }^{32}$ Ultimately, solidarity lending enables the bank to shift to borrowers - now interpellated as self-governing, responsible entrepreneurs - the burden of cost and risk. ${ }^{33}$ For this reason Morgan Brigg argues that microcredit is not in fact a conceptual revolution of approaches to poverty alleviation or rural development; it diff rs only in that it is 'micro':

Notions of individual initiative, determination and provision of capital to improve
people's situation and increase economic growth are a micro-version of the dom-
inant economistic development approach, and resonate with aspects of moderniza-
tion theory which dominated in the 1950s and 1960s. Thus while it is possible to view
microcredit as a radical departure from conventional development practice, it also
exhibits signific nt continuities with the approach of previous decades and does not
introduce a rupture or signific nt shift in the dvelopment dispositif. ${ }^{34}$

Rather than the promised 'outside' on which the humanitarian imaginary depends, then, microcredit may be viewed as a vast expansion of the 'inside', extending contemporary capitalism to new markets by cultivating the ethos of 'individualinitiative' and self-determination amongst previously dsenfranchised borrowers. ${ }^{35}$

It is just this focus on the individual that has made microfi ance so att active to international donors. ${ }^{36}$ I would also argue that the att action goes even deeper than political or economic ideologies, including a cultural anti-systems fantasy that has been historically attached to the humanitarian project. In other words, the 
'micro' - equitable with the individual and with the 'simple' - is itself an object of humanitarian desire. As with Greg Mortenson, organisational power is understood as humanitarian onlyif it is reframed through the human. Positioned against the history of large-scale, top-down foreign loans and development programmes, miciofi ance off rs a hyper-local, improvisatory theory of social change that, like Three Cups, celebrates the natural intelligence of the person over the formal intelligence of the institution. Only this time it is the figure of the benefi iary, not the humanitarian founder, who theoretically serves as the naive axis of change. Th s was made possible as theideology of self-help cameto challenge that of aid in international development, turning the micro-borrower into the figure par excellence of global humanitarianism. In this context Yunus's memoir serves the important function of appropriating for the micro-lender and his institution the borrower's naive appeal, thus downplaying microcredit's affin ies with the macro fi ancial complex.

We have seen how Yunus claims the power of the 'simple' while occupying the subject-position of the poor person applying for a loan. In this way the memoir imagines Yunus's subjectivity as a collective one: Yunus conveys the rational authority of a banker and head of a lending institution while engaging and putting into play the innocent subversiveness of the fool, grounded in what the book presents as the simple 'mentality' of the aspiring micio-entrepreneur. Thus Banker advertises the naive humanitarian dimension of microcredit in opposition to the cynical sophistication of traditional banking and development approaches. Key to this project is the particular subjectivity of the microcredit founder as established through humanitarian memoir. Banker to the Poor illustrates that one of Yunus's great innovations was the creation of a new sovereign figure: the grassroots, unregulated yet corporate social entrepreneur.

\section{Conclusion}

If the central appeal of the naive to humanitarian studies is its promise of an intellectualand practical 'outsidè to state and corporate sectors, both CAI and Grameen Bank have disappointed hopes that they would deliver. That this is the case in both examples selected is not intended as an empiricalindictment of that promise; rather, the revelations of 'inside complicity serve to highlight how strong is the desire forthe institutionalisation of a humanitarian alternative in public culture, that even those cases most hailed as harbingers of such an alternative still demonstrate the difficulty of its attainment. I have presented these two founder memoirs as examples of the prominence and use of the naive in humanitarian life-writing. Three Cups of Tea and Banker to the Poor depict two complementary figures who populate the genre: the naive pioneer and the naive philosopher. Each fulfils its own reader fantasy. In the fi st type, naive humanitarianism is defin $\mathrm{d}$ as a combination of professional innocence and gut instinctthat helpsthefounderbridge heterogeneousworlds in order to build new institutions. In the second humanitarianism appears as naive questioning 
of establishment fi st principles, with the founder adopting the role of simpleton in order to eff ct a fundamental change in supposedly self-evident practices and ways of thinking. But they also share important appeals to the reader, including a suspicion of 'expert' knowledge and planning and a belief that humanitarian institutions should be 'human' - whether through literal identific tion, as in the case of Greg Mortenson and the Central Asia Institute, or by following small-scale thinking and approaches, as we see with Muhammad Yunus's story of his founding of microcredit and the Grameen Bank. Above all, the 'naive' of the institution's benefi iaries should be absorbed, mirrored or complemented by the founder himself. Thus Three Cups' Mortenson, whose personality appears in bold contrast to that of Western executive and administrative culture, is at home in the 'wild' of northern Pakistan. ${ }^{37}$ And Banker's Yunus constructs a ground-breaking economictheory and practice based on the experience and point of view of 'illiterate' rural women. Th se traits, though perhaps most prominent in the founder genre, also influ nce the construction of aid worker memoirs, highlighting the special contributions that memoir, a genre constructed on the power of personality and confessional authenticity, has made to humanitarian narrative during a time of industry professionalisation and expansion.

\section{Notes}

1 H. Dunant and International Committee of the Red Cross, A Memory of Solferino (Geneva: International Committee of the Red Cross, 1986); M. Tho sen, Living Poor: A Peace Corps Chronicle (Seattle: University of Washington Press, 1969).

2 On the other hand, Bertrand Taithe points out that in comparison with other industries (for instance the 69-billion-dollar yogurt market or 1.5-trillion-dollar weapons industry) global humanitarianism remains 'artisanal. 'The Poverty of Humanitarian Critique?' (7 July 2014), https:// historyofhumanitarianaid.com/2014/07/07/the-poverty-of-humanitarian-critique/ \#_ftn. Accessed 20 May 2017.

3 M. Barnett, Empire of Humanity: A History of Humanitarianism (Ithaca: Cornell University Press, 2011), p 105.

4 Barnett, Empire of Humanity, p. 108. Tales of the imperfect implementation of this project are legion, often testifying to a blind faith in technology without consideration of context, maintenance or potential disruption to wider systems - often with devastating consequences. See, for example, Ilana Feldman's critique of CARE's attemptsto bring electricity to Gaza, Michael Maren's takedown of Peace Corps water towers in Kenya, and, in broader strokes, Arturo Escobar's analysis of the long-term eff cts of the Green Revolution. See I. Feldman, 'The Humanitarian Circuit: Relief Work, Development Assistance, and CARE in Gaza, 1955-67', in E. Bornstein and P. Redfi ld (eds), Forces of Compassion: Humanitarianism between Ethics and Politics (Santa Fe: School for Advanced Research Press, 2011),pp. 203-26; M. Maren, The Road to Hell: The Ravaging Effects of Foreign Aid and International Charity (New York: Free Press, 1997); A. Escobar, Encountering Development: The Making and Unmaking of the Third World (Princeton: Princeton University Press, 2012).

5 Originally introduced by CARE, kits have now become a staple of Médicins Sans Frontières' global mobilisation of medicalrelief. See P. Redfi ld, Life in Crisis: The Ethical Journey of Doctors Without Borders (Berkeley and Los Angeles: University of California Press, 2013), pp 79-80. 
6 M. Barnett and T. Weiss, 'Humanitarianism: A Brief History of the Present', in M. Barnett and T. Weiss (eds), Humanitarianism in Question: Politics, Power, Ethics (Ithaca: Cornell University Press, 2008), p. 47.

7 J. Hailey and M. Sorgenfrei, 'Measuring Success: Issues in Performance Management', Occasional Papers Series 44 (Oxford: INTRAC, 2004); R. Hummebrunner, 'Beyond Logframe: Critique, Variation, and Alternatives', in F. Nobuko (ed.), Beyond Logframe: Usings Systems Concepts in Evaluation (Tokyo: Foundation for Advanced Studies on International Development, 2010), pp. 1-2.

8 Practical Concepts Incorporated (PCI), 'The Logical Framework: A Manager's Guide to a Scientific Approach to Design and Evaluation' (Washington, DC: PCI, 1979), pp. 1-2; D. Lewis, Non-Governmental Organizations, Management and Development (Oxford and New York: Routledge, 3rd edn, 2014), pp 34-5.

9 It is now possible to get a bachelor's or master's degree in Europe and North America in such areas as Global Humanitarian Engineering, Logistics Management-Humanitarian andDisaster Relief, Refugee and Forced Migration Studies, and International Humanitarian Action.

10 A. Talty, 'Seven Tips for Becoming an International Aid Worker', Forbes (10 October 2013), www.forbes.com/sites/ alexandratalty/2013/10/ 10/ millenialthursdays-the-down-and-dirtyof-international-aid-work/; K. Warren, '12 Graduate Degree Programs to Further Your Global Development Career', Devex (6 October 2015), www.devex.com/news/ 12-graduatedegree-programs-to-further-your-global-development-career-87058. Accessed 20 May 2017. A global, standardised certific tion system has yet to be realised, however. A report fi anced by the European Commission concludes that there is still a need for certifi d training 'based on a global standardized system', including more master's programs, given wide variations in apprenticeship and credentialing, lack of a core curriculum, and lack of availability of fi ld internships as part of some degree certific tions. See EUPRHA (European Universities on Professionalization of Humanitarian Action), 'Emerging Trends in Humanitarian Action and Professionalization of Humanitarian Aid Workers' (2014), www.researchgate.net/ publication/271826714_Emerging_trends_in_humanitarian_action_and_professionalization_of_ humanitarian_aid_workers, pp.22-3. Accessed 20 May 2017.

11 D. Fassin, Humanitarian Reason: A Moral History of the Present, trans. R. Gomme(Berkeley, Los Angeles and London: University of California Press, 2012).

12 L. Smirl 'The State We Aren't In: Liminal Subjectivity in Aid-Worker Autobiographies', in B. Bliesemann de Guevara (ed.), Statebuilding and State-Formation: The Political Sociology of Intervention (Oxon and New York: Routledge, 2012), pp. 230-45. In Smirls samples all subjects descend into a despair and disillusionment that prompt the fi al return home; this trait distinguishes them from the memoirs of Peace Corps volunteers, who have signed up for cultural exchange as well as humanitarian work and hence tend to be less ambitious about eff cting change in their hos countries.

13 J. Schuessler, 'Insidethe List', New York Times Book Review (22 April 2011), www.nytimes.com/ 2011/05/01/books/ review/InsideList-t.html. Accessed 20 May 2017.

14 In the 2013 memoir Chasing Chaos, for instance, Jessica Alexander arrives in Sudan long past her initial ignorance of international affai s (now she knows how to spell Tegucigalpa), but she has no sense of direction, clinging to her unnamed NGO's formulated wisdom and planning strategies. As she continues to work, however, she realises that 'naivete and humility actually worked to my advantage', making her more receptive to the input and advice of the community. See J. Alexander, Chasing Chaos: My Decade In and Out of Humanitarian Aid (New York: Broadway Books, 2013), p. 163. 
15 J. Foreman, 'Pakistan: Free to Learn', Telegraph (16 February 2008), www.telegraph.co.uk/culture/ books/ 367 1228/ Pakistan-Free-to-learn.html. Accessed 20 May 2017.

16 G. Mortenson and D. O. Relin, Three Cups of Tea: One Man's Mission to Promote Peace One School at a Time (New York: Penguin,2006), pp. 4, 3. Subsequent references will be provided parenthetically in thetext.

17 N. Ali, 'Books vs Bombs?Humanitarian Development and the Narrative of the War on Terror in Northern Pakistan', Third World Quarterly, 31:4 (2010), pp. 541-59. As Ali also points out, the book's essentialisation of Northern Pakistani culture and its reliance on standard 'tropes of backwardness' also contributed to its use by the US government during reconstruction effo ts during the war on terror.

18 When Greg gets to Korphe he is leading a procession of fifty curious children. 'The children fi gered his shalwar, searched his wrists for the watch he didn't wear, and took turns holding his hands' (24). How the children, who we are told earlier had never before seen a foreigner, knew that a foreigner would mo likely wear a watch is never explained.

19 G. Mortenson and D. O. Relin, Three Cups of Tea: The Young Readers Edition, adapted by S. Thomsen (New York: Penguin, 2009), p. 23.

20 Foreman, 'Pakistan: Free to Learn'.

21 J. Krakauer, Three Cups of Deceit: How Greg Mortenson, Humanitarian Hero, Lost His Way (New York: Anchor Books, 2011). Krakauer has since followed up, reporting that corruption remains endemicin CAI and that some of the 'Dirty Dozen' of ragtag misfitsMortenson hired have diverted huge sums from the organisation. See 'Is it Time to Forgive Greg Mortenson?' Daily Beast (8 April 2013), www.thedailybeast.com/articles/ 2013/04/ 08/ is-it-time-to-forgivegreg-mortenson.html. Accessed 20 May 2017.

22 P. Hessler, 'What Mortenson Got Wrong', New Yorker (21 April 2011), www.newyorker.com/ news/ news-desk/ what-mortenson-got-wrong. Accessed 20 May 2017.

23 J. M. McGlinn, 'A Study Guide to the Penguin Edition of Greg Mortenson and Oliver Relin's Three Cups of Tea' (no date), www.penguin.com/static/pdf/teachersguides/ Th eeCupsOfTeaTG.pdf, p. 7 .

24 Mountains Beyond Mountains, Tracy Kidder's 2003 biography of Paul Farmer, a doctor and infectious diseases specialist who co-founded the NGO Partners in Health, is a well-known example; and, although he does not mention this background in his 1862 memoir A Memory of Solferino, Henri Dunant was an experienced social activist, able to apply his knowledge and skills to medical crises in work leading to the foundng of theICRC.

25 Criticisms include its high interest rates, which increase the risk of loan default and overindebtedness; misrepresenting loan recovery rates; producing loan recycling and consumption smoothing instead of economic development; failing to demonstrate any signific nt reduction in poverty or women's empowerment; and creating psychological trauma amongst those popultions that use the indusry's famous goup lending approach.

26 WorldBank, 'Does Microfi ance Still Hold Promise for Reaching the Poor?' (30 March 2015), www.worldbank.org/ en/ news/ feature/ 2015/03/30/ does-microfi ance-still-hold-promisefor-reaching-the-poor. Accessed 20 May 2017.

27 R. Williams, Keywords: A Vocabulary of Culture and Society (Abingdon: Routledge, 2011), p. 13.

28 W. M. Maathai, Unbowed: A Memoir (New York: Alfred A. Knopf, 2006), p. 135

29 M. Yunus with A. Jolis, Banker to the Poor: Micro-Lending and the Battle Against World Poverty (New York: Public Affai s, 1999), p. vii. Subsequent references will be provided parenthetically in thetext. 
30 Theliteral personal touch is the simple foundation of the trust between borrower and bank, humanising the inhuman world of debt and fi ance. Grameen's vision here may be hailed as the banking corollary to Marx's famousdictumabout commercial transactions: that however obscured by commodities, in the end the relationship is a social one, between people rather than between things.

31 In the decades following, Grameen wouldadvertise a still impressive 98 per cent loan recovery rate. However, as L. Karim points out, this figure includes forced recoveries as well as voluntary ones, which may be misleading. See Microfinance and its Discontents: Women in Debt in Bangladesh (Minneapolis: University of Minnesota Press, 2011), pxxii.

32 M. Bateman, Why Doesn't Microfinance Work? The Fragile Illusion of Local Neoliberalism (London Zed Books, 2010), pp. 160-5; Karim,Microfinance and its Discontents, p. xvi.

33 Bateman, Why Doesn't Microfinance Work? p. 160; D. M. Roodman, Due Diligence: An Impertinent Inquiry into Microfinance (Washington, DC: Center for Global Development, 2012), p. 106. Bateman comments on the burden shift in terms of high interest rates; the application of this logic to solidarity lending is my own. The goal also includes independence from the local predatory moneylenders and from their husbands and male kin. The extent to which either of these forms of independence actually occurs has been contested, withloan moneysometimes appropriated by husbands or other male kin or funnelled back into local moneylender circuits. See A. M. Goetz and R. S. Gupta, 'Who Takes the Credit? Gender, Power, and Control Over Loan Use in Rural Credit Programs in Bangladesh', World Development, 24:1 (1996), pp. 49-50; Roodman, Due Diligence, pp. 25-7. In evaluating the status of the loan as an intra-household commodity and object of resource leverage and manipulation, Goetz and Gupta quote one field worker as saying that credit 'is just another form of dowry', though they point out that amongst the organisations they surveyed in Bangladesh, Grameen Bank had the highest rate of female control over loans given $(54,60)$. Karim also notes the contradiction between the ideology of rational sovereignty and kinship constraints acting on these female borrowers (Microfinance and its Discontents, p. xvi).

34 M. Brigg, 'Disciplining the Developmental Subject: Neoliberal Power and Governance through Microcredit', in J. L. Fernando (ed.), Microfinance: Perils and Prospects (London and New York: Routledge, 2006), pp. 66-7.

35 Its great success is incorporating the economicaly marginalised into an institutional system that - while potentially empowering them as free agents - nevertheless also maintains their subordination as ditizens and to private indusry.

36 M. Bateman and H.-J. Chang, 'Microfi ance and the Illusionof Development: From Hubris to Nemesis in Thity Years', World Economic Review 1 (2012), pp. 28-9.

37 For a discussion of the portrayal of rural Pakistan as 'wild' in the memoir see Ali, 'Books vs. Bombs?'

\section{References}

Alexander, J., Chasing Chaos: My Decade In and Out of Humanitarian Aid (New York: Broadway Books, 2013).

Ali, N., 'Books vs Bombs? Humanitarian Development and the Narrative of the War on Terror in Northern Pakistan', Third World Quarterly, 31:4 (2010), pp. 541-59.

Barnett, M., Empire of Humanity: A History of Humanitarianism (Ithaca: Cornell University Press, 2011). 
Barnett, M. and T. Weiss, 'Humanitarianism: A Brief History of the Present', in M. Barnett and T. Weiss (eds), Humanitarianism in Question: Politics, Power, Ethics (Ithaca: Cornell University Press, 2008), pp. 1-48.

Bateman, M., Why Doesn't Microfinance Work? The Fragile Illusion of Local Neoliberalism (London Zed Books, 2010).

Bateman, M. and H.-J. Chang, 'Microfi ance and the Illusion of Development: From Hubris to Nemesis in Thity Years', World Economic Review 1 (2012), pp. 13-36.

Brigg, M., 'Disciplining the Developmental Subject: Neoliberal Power and Governance through Microcredit', in J. L. Fernando (ed.), Microfinance: Perils and Prospects (Londonand New York: Routledge, 2006), pp. 55-76.

Dunant, H. and International Committee of the Red Cross, A Memory of Solferino (Geneva: International Committee of the Red Cross, 1986).

Escobar, A., Encountering Development: The Making and Unmaking of the Third World (Princeton: Princeton University Press, 2012).

EUPRHA (European Universities on Professionalization of Humanitarian Action), 'Emerging Trends in Humanitarian Action and Professionalization of Humanitarian Aid Workers' (2014), www.researchgate.net/publication/27 1826714_Emerging_trends_in_humanitarian_ action_and_professionalization_of_humanitarian_aid_workers. Accessed 20 May 2017.

Fassin, D., Humanitarian Reason: A Moral History of the Present, trans. R. Gomme (Berkeley and Los Angeles: University of California Press, 2012).

Feldman, I., 'The Humanitarian Circuit: Relief Work, Development Assistance, and CARE in Gaza, 1955-67', in E. Bornstein and P. Redfi ld (eds), Forces of Compassion: Humanitarianism between Ethics and Politics (Santa Fe: School for Adunced Research Press, 2011), pp 203-26.

Foreman, J., 'Pakistan: Free to Learn', Telegraph (16 February 2008), www.telegraph.co.uk/culture/ books/367 1228/ Pakistan-Free-to-learn.html. Accessed 20 May 2017.

Goetz, A. M. and R. S. Gupta, 'Who Takes the Credit? Gender, Power, and Control Over Loan Use in Rural Credit Programs in Bangladesh', World Development 24:1 (1996), pp. 45-63.

Hailey, J. and M. Sorgenfrei, 'Measuring Success: Issues in Performance Management', Occasional Papers Series 44 (Oxford: INTRAC, 2004), www.alnap.org/pool/files/ ops-44-measuringsuccess.pdf. Accessed 20 May 2017.

Hessler, P., 'What Mortenson Got Wrong', New Yorker (21 April 2011), www.newyorker.com/ news/news-desk/what-mortenson-got-wrong. Accessed 20 May 2017.

Hummdbrunner, R., 'BeyondLogframe: Critique, Variation, and Alternatives', inF. Nobuko (ed.), Beyond Logframe: Usings Systems Concepts in Evaluation (Tokyo: Foundation for Advanced Studies on International Development, 2010), pp. 1-33.

Karim,L., Microfinance and its Discontents: Women in Debt in Bangladesh (Minneapolis: University of Minnesota Press, 2011).

Krakauer, J., Three Cups of Deceit: How Greg Mortenson, Humanitarian Hero, Lost His Way (New York: Anchor Bodks, 2011).

Krakauer, J., 'Is it Timeto Forgive Greg Mortenson?' Daily Beast (8 April 2013), www.thedailybeast. com/articles/2013/04/08/is-it-time-to-forgive-greg-mortenson.html. Accessed 20 May 2017.

Lewis, D., Non-Governmental Organizations, Management and Development (Oxford and New York: Routledge, 3id edn, 2014).

Maathai, W. M., Unbowed: A Memoir (New York: Alfred A. Knopf, 2006).

Maren, M., The Road to Hell: The Ravaging Effects of Foreign Aid and International Charity (New York Free Press, 1997). 
McGlinn,J. M., 'A StudyGuideto the PenguinEdition of Greg Mortenson and Oliver Relin's Three Cups of Tea' (no date), www.penguin.com/static/ pdf/teachersguides/Th eeCupsOfTeaTG. pdf. Accessed 20 May 2017.

Mortenson, G. and D. O. Relin, Three Cups of Tea: One Man's Mission to Promote Peace One School at a Time (New York: Penguin,2006).

Mortenson, G. and D. O. Relin, Three Cups of Tea: The Young Readers Edition, adapted by S. Thomsen (New York: Penguin,2009).

Practical Concepts Incorporated (PCI), 'The Logical Framework: A Manager's Guide to a Scientific Approach to Design and Evaluation' (Washington, DC: PCI, 1979), http:// pdf. usaid.gov/pdf_docs/pnabn963.pdf. Accessed 20 May 2017.

Redfi ld, P., Life in Crisis: The Ethical Journey of Doctors Without Borders (Berkeley, Los Angeles and London: University of California Press, 2013).

Roodman, D. M., Due Diligence: An Impertinent Inquiry into Microfinance (Washington, DC: Center for Gldbal Development, 2012).

Schuessler, J., 'Inside the List', New York Times Book Review (22 April 2011), www.nytimes.com/ 2011/05/01/books/ review/InsideList-t.html. Accessed 20 May 2017.

Smirl L., 'The State We Aren't In: Liminal Subjectivity in Aid-Worker Autobiographies', in B. Bliesemann de Guevara (ed.), Statebuilding and State-Formation: The Political Sociology of Intervention (Oxon and New York: Routledge, 2012), pp. 230-45.

Taithe, B., 'The Poverty of Humanitarian Critique?' (7 July 2014), https:// historyofhumanitarianaid. com/2014/07/07/the-poverty-of-humanitarian-critique/\#_ftn . Accessed 20 May 2017.

Talty, A., 'Seven Tips for Becoming an International Aid Worker', Forbes (10 October 2013), www. forbes.com/sites/alexandratalty/2013/10/ 10/ millenial-thursdays-the-down-and-dirty-ofinternational-aid-work/. Accessed 20 May 2017.

Tho sen, M., Living Poor: A Peace Corps Chronicle (Seattle: University of Washington Press, 1969).

Warren, K., ' 12 Graduate Degree Programs to Further Your Global Development Career', Devex (6 October 2015), www.devex.com/news/ 12-graduate-degree-programs-to-further-yourglobal-development-career-87058. Accessed 20 May 2017.

Williams, R., Keywords: A Vocabulary of Culture and Society (Abingdon: Routledge, 2011).

World Bank, 'Does Microfi ance Still Hold Promise for Reaching the Poor?' (30 March 2015), www.worldbank.org/ en/news/ feature/ 2015/03/30/ does-microfi ance-still-hold-promisefor-reaching-the-poor. Accessed 20 May 2017.

Yunus, M. with A. Jolis, Banker to the Poor: Micro-Lending and the Battle Against World Poverty (New York: Public Affai s, 1999). 


\title{
'Telegenically dead Palestinians': Cinema, news media and perception management of the Gaza conflicts
}

\author{
Shohini Chaudhuri
}

In the animated film Waltz with Bashir (2008) about the director Ari Folman's attempts to recover his and other ex-soldiers' memories of the 1982 Lebanon War, we hear the story of an amateur photographer. He coped by picturing everything through an imaginary camera, which protected him from the horrors. With still images, the film tries to show us how a traumatised soldier sees the war as distanced 'snapshots.' When his imaginary camera 'breaks', still frames jam in the shutter gate, then become moving images of a derelict landscape, where injured 'Arabian horses' pitifully collapse and die.

As Karen Lury writes, 'Tears and emotion erupt when the innocent - dumb animals, little children - are seen to suff r'; theirblamelessness magnifi s the harms of war. ${ }^{1}$ Yet, there is something disingenuous about this scene of pity in Waltz with Bashir. Why are they Arabian horses? Could those horses, revealed by the broken camera, actually be Arabs? As in its anecdote of another soldier who could only shoot dogs, and now suff rs nightmares of being chased by them, the film's use of animal imagery makes it easier to discount that people are suff ring and dying. It is a kind of 'perception management' - a term that I draw from the journalist Mark Curtis - that leads us into an inward, aff ctive engagement through the soldiers' perspective: what the var did to them, not what they did to others. ${ }^{2}$

In a previous publication, I drew parallels between this film and mainstream Western news media, which routinely prioritises the Israeli viewpoint. ${ }^{3}$ Now I would like to show what occurs when humanitarian images of Palestinian casualties take centre stage, as they did during the 2014 Israeli bombardment of Gaza. Here, I will argue that a media outcome that appears to be farourable to the Palestinians, in that it focuses on their suff ring, can actually have the opposite eff ct. To illustrate my argument about the framing of humanitarian images, I will refer to a range of media texts related to the Gaza conflicts: UK, US and Israeli news coverage, including UK journalist Jon Snow's video blog upon his return from Gaza in 2014; Waltz with Bashir, which was released around the time of the 2008-9 conflict; and the Palestinian film Where Should the Birds Fly (Fida Qishta, 2013), whichfocuses on the 2008-9 conflict and its ftermath. 
In a CNN interview, Israeli Prime Minister Binyamin Netanyahu, in response to a perceived shift in international coverage of the conflict, accused Hamas of using 'telegenically dead Palestinians' for their cause:

We're sad for every civilian casualty. The 're not intended. Ths is the diff rence between us. Hamas deliberately targets civilians and deliberately hides behind civilians. They embed their rocketeers, their rocket cachés, their other weaponry, which they use to fi e on us, in civilian areas. What choice do we have? We have to protect ourselves. We try to target the rocketeers - we do. And all civilian casualties are unintended by us but actually intended by Hamas. Theywant to pile up as many civilian dead as they can, because somebody said they use - it's gruesome - they use telegenically dead Palestinians for their case. They ant the mor dead, the better. ${ }^{4}$

Netanyahu's statement gives renewed signific nce to what Paul Virilio calls the 'logistics of perception' - that a 'war of pictures and sounds' rages alongsideconflicts and shapes our attitudes towards them as just or unjust. ${ }^{5}$ Ostensibly highlighting that images of destruction in Gaza spelled a public relations disaster for Israel, Netanyahu's statement contains the Israeli public relations narrative, through which public perceptions of Israel's actions against Palestinians are managed. For Curtis, perception management is a tool used by the powerful to disseminate rhetoric about noble intentions and moral purpose, ensuring that what is friendly to theirinterests is reported and that what is unfriendly is discredited: it promotes and normalises a way of seeing the world. ${ }^{6}$ In no way uniqueto the Gaza conflicts, perception management can serve to divorce the public from realities of state violence through a kind of cinematic derealisation that enables states to reduce perceptions of blame for their atrocities and act with impunit.

\section{Why the 2014 conflict seemed different}

Th re have been three major military conflicts in the Gaza Strip in the last decade, widely known by their Israeli codenames 'Operation Cast Lead' (2008-9), 'Operation Pillar of Defence' (2012) and 'Operation Protective Edge' (2014).During the twenty-two-day 'Operation Cast Lead', in which around 1,400 Palestinians and thirteen Israelis were killed, Israel banned foreign joumalists from entering the Gaza Strip. Th refore, the conflict was reported by Palestinian joumalists inside Gaza and foreign reporters stationed on a hill outside - a strategy designed to avert public reaction to pictures of dead Palestinians, although it did not stop the fl w of images from Gaza. ${ }^{7}$ However, for the eight-day 'Operation Pillar of Defence' and fifty-day 'Operation Protective Edge' - the most devastating of these conflicts, resulting in the deaths of over 2,000 Palestinians, seventy-two Israelis (sixty-six of them soldiers) and 1Thai - the ban was lifted, enabling images of Palestinian deaths and injuries to gain centre stage. 
As one user commented in 2014 on the news website Mondoweiss, 'Th re is not one Phan Thi Kim Phuc photo (the little naked girlfl eing a napalm strike in Viet Nam) but the combined photos and stories from Gazathis timehave indeed changed the imagery of this conflict in the American mindset.' Th se words recall the widely held, though inaccurate, view that a critical news media shifted public opinionfrom a 'just war' to a 'dirty war' in Vietnam. ${ }^{9}$ One of the Vietnam-like moments was the killing of four boys, Ismail, Mohammad, Zakariya and Ahed, all aged 9-11, playing on a Gaza beach; they were caught on CCTV when shells started falling. ${ }^{10}$ NBC journalist Ayman Mohyeldin, who was at the scene, instantly tweeted the story. In the UK, the incident became the focus of testy interviews with Israeli officials - for example, the Channel 4 anchor Jon Snow interrogated the Israeli Prime Minister's Chief Spokesperson Mark Regev on how killing children squared with the stated aim of Operation Protective Edge' to protect Israeli people. ${ }^{11}$

A major part of what made the 2014 conflict seem diff rent was widespread use of social media as a tool for exposure of violence against Palestinians, without the usual editorial filters. Social media filled in some of the gaps of mainstream coverage, often from the perspectives of Palestinians withinwarzones, live-tweeting updates including video clips of bombardment and pictures of devastation and injured children. Th s made, Ben White claims, 'the lived experience of the colonised accessible in new ways and by new audiences. ${ }^{12}$ For journalist and broadcaster Paul Mason, social media has wrought a huge shift in the balance of power towards people and away from governments. Whilst Western mainstream media, especially in the United States, is 'traditionally heavily skewed towards the pro-Israeli view ... now, for the fi st time, in a major Arab-Israeli conflict, the American public has other sources of reality', namely endless pictures of dead Palestinian children:

Netanyahu complained that the Hamas strategy was to provide 'telegenically dead' people but where Israel is losing the hearts and minds of the world is not via 'tele' anything: it is in the JPEGs that stream into millions of people's mobile phones. ${ }^{13}$

However, social media is also subject to perception management, and considered a battl groundforpublic opinionby both parties to the conflict and theirinternational supporters. As during the 2012 conflict, described as 'the fi st social media war', ordinary citizens claimed the hashtags \#GazaUnderAttack and \#IsraelUnderFire to exchange 'reports, opinions, and challenges to mainstream news reports and to each other' ${ }^{14}$

In theirbook Digital Militarism, Adi Kuntsman and Rebecca Stein off r a counterargument to optimism about social media's ability to override official narratives, by showing how it can be mobilised for repressive state ends. ${ }^{15}$ In this light, let us return to Netanyahu's phrase 'telegenically dead', which he appears to be quoting from somewhere. He reduces the materiality of Palestinian deaths to the production of pixels on a screen, hinting that the images were faked. Suspicion of images of dead 
or injured Palestinians circulating in international media (but not in Israeli national media, which mostly focuses on Israeli suff ring) is commonpace on pro-Israeli social media. For Kuntsman and Stein, this 'digital suspicion', which defl cts issues of Israeli violence onto alleged fraudulence and attempts to defame Israel, functions as 'a surrogate media ban, enforced not by state censorship but by everyday readers and social media consumers themselves. ${ }^{16}$

In 2012 and 2014, therefore, images of dead and injured Palestinians gained centre stage amidst a form of perception management to which digital suspicion belonged. Concomitant with charges of fakery was the accusation that Palestinian deaths were caused by Palestinians themselves, mainlyby Hamas's disregard for its own people, rather than by Israel - a narrative equally exemplifi d by Netanyahu's statement and visually embodied in the infographics of Israel Defence Forces (IDF) tweets about the housirg of Hamas's weapons cachés in divilian areas.

While social media participate in and extend perception management, the more open climate they have fostered has allowed 'establishment journalists ... to be more forthcoming' about what is happening on the ground ${ }^{17}$ In the UK, one of the most outspoken journalists was Jon Snow, who made a heartfelt emotional appeal in a video blog upon his return from Gaza. ${ }^{18}$ Tho gh filmed in the Channel 4 studio, it was intended for online distribution and posted on YouTube. The video recounts what Snow witnessed in Gaza, images that are 'etched' in his mind particularly his visit to al-Shifa hospital and his encounter with a two-and-a-half-year-old girl with panda-like eyes due to bruises from her broken skull. One of the definiive images of Palestinian suff ring that summe, Snow's video went viral, gaining over one million views 'across multiple platforms' within fi e days. ${ }^{19}$

As Susan Sontag has remarked, 'so far as we feel sympathy, we feel we are not accomplices to what caused the suff ring. ${ }^{20}$ Standard humanitarian images position viewers as benevolent helpers, letting us off the hook regarding our own implication in that suff ring. Snow's video breaks this convention by using the humanitarian image to highlight UK complicity in the suff ring of Palestinian children. Citing official statistics of child deaths in the conflict to date, he states: 'We have to know that, in some way, we share some responsibility for those deaths.' The video even prompted an eight-year-old girl to write to the British Foreign Secretary. 'We are killing the people of Gaza by giving Israel weapons. We need to take our part in it and stop giving Israel weapons. ${ }^{21}$ The video invites UK citizens to make links between themselves and the suff ring, through their own government's culpability.

Yet, Snow's emotive appeal is anchored in the iconography of the passive, suff ring child in need of rescue. In this respect, it is similar to conventional humanitarian images, such as the Disasters Emergency Committee Gaza crisis appeal poster of a lone boy, surrounded by rubble. Separated from their wider societal context, pictures of children withimploring eyes are usually used to raise funds fortheirbasic needs. According to Wendy Hesford, in order to generate sympathy, such humanitarian images deploy a visual rhetoric that reproduces repressive Western ideologies, 
depriving endangered children of any agency. ${ }^{22}$ A generic victim, the injured girl in Snow's video is not even given a name. ${ }^{23}$ Didier Fassin writes that 'the prolixity of humanitarianism increases in parallel to the silence of the survivor. ${ }^{24}$ The humanitarian speaks in the child's name, becoming a spokesperson 'for the supposedly voiceless. ${ }^{25}$

Susan Moeller has observed that the prevalent focus on children as innocent victims' elicits sympathy on an 'apolitical or suprapolitical level. ${ }^{26}$ The killing and injuring of children, who are unable to protect themselves and who do not pose any threat to soldiers, was therefore considered safe territory for UK joumalists when interrogating Israeli officials. However, Palestinian teenagers and children are regularly shot and killed by Israeli forces - a violence so routine it is generally not considered newsworthy. Furthermore, a vulnerable child killed or injured while playing in a park or the beach elicits instant public sympathy, unlike a teenager involved in resistance or unrest. The Palestinian child, however, is a long-standing icon of Palestinian resistance, as in the cartoon character Handala created by the artist Naji al-Ali. Appearing as graffiti in Palestine, Handala is a boy with his back turned, symbolising the Palestinian refugee who will not look forward until he returns home: a very diff rent image of the chld from humanitarian ones.

\section{How the structure of mainstream reporting endorses the Israeli perspective despite focus on Palestinian casualties}

Analysing media coverage of the 2008-9 conflict, the Glasgow Media Group found that humanitarian focus on Palestinian suff ring can be allied to a structure of news reporting that prioritises the official Israeli perspective. I contend that this structure of news reporting applies to the 2014 conflict. Even when joumalists were critical of civilian casualties, they tended to endorse the Israeli narrative - for example, that the kidnap and murder of three Israeli teens in June 2014 formed the 'backdrop' to the conflict. ThePalestinian perspective on these events - or indeed, any perspective other than the official Israeli one - tended to be missing. ${ }^{27}$ As the Glasgow Media Group discovered, much of what the public takes to be true are 'exactly the points ... highlighted in Israeli public relations and reported uncritically on the news. Crucially, this can aff ct how audiences apportion blame and responsibility and also influ nce how ... images of divilian casualties [are] interpreted. ${ }^{28}$

UK news media often try to 'balance' the Israeli and Palestinian perspectives in a way that is thought to be objective. For example, the BBC's News at Ten combined an elegiac slideshow of life in the Gaza rubble, highlighting the humanitarian disaster, with a feature on Gaza's 'terror tunnels' and reports confi ming that Israel was hitting Hamas targets. ${ }^{29}$ Such 'balancing' presents a skewed picture of the conflict and fails to convey the fundamental power asymmetry underlying it.

NGO images suff $r$ from similar problems. Gaza is frequently rehearsed in terms of humanitarian statistics, described as one of the most densely inhabited 
places in the world, with around 1.8 million residents, 80 per cent of whom are dependent on humanitarian aid. ${ }^{30}$ Such images can make Palestinians in Gaza seem only a humanitarian problem, thereby eliding the political context of their oppression and struggle for justice. The majority of Gaza's population are refugees, descendants of those displaced from historic Palestine when the Israeli state was created there in 1948. Theywere expelled across what was then an imaginary boundary, which later became fenced to prevent them from returning to their homes, turning into the hard border of a new geographical entity called the Gaza Strip. Since then, further political factors have exacerbated their situation - amongst them, Israel's expansionist policies of expropriating more land and resources.

As Jehad Abu Salim asserts, 'because the current Gaza Strip is a product of politicalhistory, humanitarian discourse contributes to normalizing Gaza's current reality, transforming it into another case ... of hunger and poverty that the international community has to deal with through aid and expertise. ${ }^{31}$ Moreover, humanitarian agencies address only the symptoms, not the causes, of crises. Many of them seek to avoid politicising the situation. However, the refusal to deal with politics can never work because the situation that the Palestinians face is thoroughlypolitical. While, on the one hand, Israeli suspicion towards bodies of Palestinian victims disavows theirhumanitarian claims, on the other, exclusive focus on theirhumanitarian status disavows their pditical chims, as a pøple colonised by Israel.

On the news, the Gaza conflicts are typically described as 'wars' between Israel and Hamas, disconnected from a history of colonisation and occupation. We are repeatedly told that Israel is under terrorist attack by Hamas rockets, fi ed into Israeli territory from Gaza, and is simply 'responding'. A huge part of Israel's perception management during the 2014 conflict was to conflate Hamas with the global threat of radical Islam, whilst presenting Israel as part of the democratic world from which Hamas is excluded, although Hamas itself was democratically elected. As John Berger remarks in another context, a sure-fi e way to discredit and eradicate your opposition is 'by calling it terrorist. ${ }^{32}$

The emphasis on Hamas, not Israel, as a terror organisation that causes suff ring to civilians also enables a shift of responsibility for the killing, as can be seen in an account given by an Israeli history student, Sophie Tal, featured on the BBC website, in which the killing of Palestinian civilians is justifi $\mathrm{d}$ as a response to terrorism:

Th $\mathrm{s}$ is about us defending ourselves from terrorists ... I feel very sorry for the people in Gaza too, but what can we do when they have fighters shooting at us from hospitals, from the roof of UN schools and using these places to launchterror attacks? We have to stop the terrorists who are using their own people as human shields. In this case targeting those buildings is the moral and right thing to do ... Israel had the fi epower to fin sh this a lot quicker. We could have bombed Gaza completely but we didn't because we are more humane than Hamas. ${ }^{33}$ 
The message that Hamas is a terrorist organisation makes it easier to blame casualties on them or, if not, to blame Israel and Hamas equally, as indeed many onlookers did, as testifi d by a CBS News Poll, taken in the United States at the height of the 2014 conflict. ${ }^{34}$ Asked who they thought was mostly to blame for the fighting, 6 per cent of respondents replied 'Israel', 34 per cent named Hamas, 47 per cent answered 'Both sides equally' and $\mathrm{D}$ per cent were unsure or gave no answer.

In the UK, Channel 4 News explained the Palestinian view of the conflict more clearly than the BBC. It featured interviews with Hamas spokespeople in Gaza which referred to eff cts of the Israeli blockade, otherwise given a low priority in the hierarchy of storytelling about the conflict, due to the predominant narrative that Israel 'gave back' Gaza in 2005, which helped sell 'the war as a defensive campaign' against terrorists who will not leave Israel in peace. ${ }^{35}$ Despite so-called withdrawal in 2005, Israel still occupies Gaza, controlling its airspace, land and sea borders, along with the fl w of goods, electricity, water, medicine and building materials; the only border Palestinians are permitted to cross is on the Egyptian side, and that is frequently shut. Theblockade was tightened shortly after Hamas took power in 2006. During 'Protective Edge', BBC journalists were told to downplay the blockade. ${ }^{36}$ Even its objective reality was questioned by phrases such as 'What Hamas is calling a blockade', used by Edward Stourton on BBC Radio 4's Today programme.

Israel regards the blockade as an economic sanction on a problematic regime. Dov Weisglass, adviser to the then Prime Minister, Ehud Olmert, said that the idea is to put the Palestinians on a diet, but not to make them die of hunger. ${ }^{37}$ The blockade works by calculating the level of calories, electric current and other necessities required to sustain the population at 'the limit of bare physical existence. ${ }^{38}$ Israel aims to reduce Gazans to what the philosopher Giorgio Agamben calls 'bare life' - a people with purely biological needs, making them liable to be killed with impunity but not sacrifi ed. ${ }^{39}$ Th $s$ is one point where the Israeli state and humanitarian viewpoints mirror each other for, as Agamben points out, 'humanitarian organizations ... can only grasp human life in the figure of bare or sacred life, and therefore, despite themselves, maintain a secret solidarity with the very powers they ought to fight.' ${ }^{40}$

The conditions that the blockade is intended to induce would have been far worse without the hundreds of tunnes dug underneath the Gaza-Egypt border to bring supplies of food fuel, livestock and appliances as well as weapons. Along with Hamas fi ing rockets, tunnels rose to the top of the hierarchy of mainstream media storytelling about 'Protective Edge'; this time, the spotlight was on the 'discovery' of 'terror tunnels' between Gaza and Israel, so called to inspire fears about Israelis being abducted by Palestinian fighters and provide the pretext for further Israeli violence. Rockets and tunnels were presented as an existential threat to Israel and Israelis. For example, BBC coverage emphasised the need for security and stopping the smuggling of weapons through tunnds. Embedded with the IDF, the correspondent, Orla Guerin, took us into tunnds constructed by 'Palestinian militants' 
in order to 'infiltrate' Israel. ${ }^{41}$ Th s long presentation on the tunnels, with extended commentary on their engineering, how dangerous they are, and the need for Israel to do something about them, became one of the 'most watched' videos on the BBC website at the time.

Historically, 'infiltrators' is the term for Palestinians who attempted to cross the Gaza Strip boundary (which became the 1949 armistice line) in order to return home, and who, when apprehended, were often killed. ${ }^{42}$ Th s provides a context for understanding the anxiety provoked by the underground tunnes. The news portrayal of Palestinians as 'infiltrators' taps into the colonial imagery of the 'civilised' and 'barbarian', similar to the Hollywood Western, which, as Robert Stam and Louise Spence have remarked, 'turn[s] history on its head, by making the Native Americans appear [as] intruders on what was originally their [home]land. ${ }^{43}$ In the Western gen re, white settl rs are shown as being encircled by primitive attackers, whose hostility is in explicable. Mainstream news coverage reproduces this colonial perspective through this image of encirclement, presenting for our sympathy Israel as a besieged nation, surrounded by inexplicably hostile assailants.

When the BBC drama The Honourable Woman, another fic ional counterpart to these news media representations, aired during the 2014 conflict, its timing was described as 'serendipity'.44 In the series, Nessa Stein, an Anglo-Israeli daughter of an Israeli arms-dealer, makes amends for her father's past by turning the family company to humanitarian ends: creating telecommunications in the West Bank. Similar to news coverage, it appears to have a favourable outcome for Palestinians, including US endorsement of a Palestinian state, but its subtext and imagery express the Israeli line. Thedrama draws on the iconography of tunnels when Nessa and her Palestinian translator Atika enter Gaza to trace some funds that have been directed there. A Gazan herself, Atika arranges for them to be smuggled in via a tunne. Inside Gaza, they are taken captive - the scene of an Israeli citizen abducted by Palestinian militants encapsulating the fearful image presented on news media. Thesynopsis of this episode refers to Nessa and Atika's witnessing of atrocities in Gaza, but the atrocities theyencounter are onlyby Palestinian militants, including Nessa's rape at their hands. ${ }^{45}$ The drama portrays the destruction and dereliction of Gaza as exclusively Hamas's fault, since there is no mention of the bombings or blockade by Israel. As in news coverage, our attention is directed away from the violence of Israel and other state parties to the conflict, and focused on the Palestinians, who carry out the most visible violence.

\section{The appeal to and manipulation of International Humanitarian Law (IHL)}

In UK reportage, any criticism of Israel, either from politicians or NGOs, tends to be couched in the rhetoric of 'disproportionate response', a language of condemnation that derives from a branch of internationallaw known as International Humanitarian 
Law (IHL) or the 'laws of war'. IHL places restraints on warfare methods to limit human suff ring. Its rules and principles of proportionality, distinction between civilians and military targets, and precaution against excessive harm to civilians and civilian infrastructure focus on playing by the fair rules of war, not why there is a war in the fi st place. For example, Amnesty International, whose report on 'Protective Edge' focuses on breaches of IHL, tells Israel it shouldfind other ways of waging its conflicts in Gaza:

[Th ] Israeli military shouldlearn thelessons of this and previousconflicts and change its military doctrine and tactics for fighting in densely populated areas such as Gaza so as to ensure strict compliance with international humanitarian law, in particular the principles of distinction, proportionality and precaution. ${ }^{46}$

Amnesty's solution is to revise the weapons deployed and rules of engagement, not to halt policies that lead to atrocity. Framed in this way, humanitarian images showing the rising Palestinian death toll and destruction of Gaza's civilian infrastructure invite us to consider Israel's violence as excessive, even to call it a 'war crime', but not to question the Israeli narrative that it is responding to Hamas rockets and acting in self-defence. It endorses the aggressor, which merely has to moderate its 'response'.

As Nimer Sultany argues, 'International law does not prevent the powerful from crushing the weak, if it is done legally, that is. ${ }^{\prime 4}$ Neither does it stop civilians from being killed, as long as it can be presented as 'unintentional' or 'proportional'. It simply codifi $s$ what kinds of violence can be permitted and regarded as legitimate. For this reason, manipulation of IHL, or 'lawfare', has become a key strategy for Israel. ${ }^{48}$ Similar to the Bush administration, which employed lawyers to give legal cover to torture, IDF operations are aided by IHL experts. As George Bisharat has observed, Israel has established itself as a 'legal entrepreneur' taking advantage of the elasticity of internationallaw, whichis capable ofbeing stretched and altered through practice, in order to lend legitimacy to its violence and establish new norms. ${ }^{49}$ To this end, Israel has developed 'knockon the roof', a tactic of fi ing a warning missile before destroying a building in order to promptresidents to evacuate - a procedure that supposedly embodies the IHL principle of precaution (warning civilians of attacks) and the IDF's 'humanitarian approach to war. ${ }^{50}$ But many have been killed in homes by the warning shots themselves, and just off ring a warning does not justify an attack on a building, especially as some may be unable or too frightened to leave or, misunderstanding the instruction, they nay take cover at home.

Along with dropping leafl ts and making phonecalls before attacks, 'knockon the roof' forms part of Israel's claim to have 'the most moral army in the world, a mantra repeated in news coverage. On Newsnight, Kirsty Wark interviewed Netanyahu's adviser Dore Gold who stressed that these warnings made the IDF a compassionate institution, even though the Palestinian death toll had by then already mounted 
to over $1,000 .{ }^{51}$ In displaying compassion for the people they were bombing, Israeli spokespeople were acting on a recommendation in a manual written by Republican political strategist FrankLuntz to help Israelis influ nce Western public opinion: 'Show Empathy for BOTH sides!'52 Together with the strategy of blaming Hamas analysed earlier in this chapter, these measures are calculated to lend the impression that Israel is acting withina legal framework and doing all it can to alleviate Palestinian suff ring.

The laws of war reconcile us to war as the norm; they form an aspect of perception management. As Weizman points out, moderating violence is just another kind of violence. It belongs to the logic of 'the lesser evil' illuminted by Hannah Arendt: 'Acceptance of lesser evils is consciouslyused in conditioning the government officials as well as the popultion at large to the acceptance of evil as such ${ }^{53}$ Appeal to and manipulation of IHL, including in news coverage, thus becomes a way of perpetuating intolerable injustice. It enables Israel to carry on its policies with international support, nomalising the violence. It leads to acceptance of the 'lesser evil', so that, Weizman says, a greater evil' may be gradually impord on the Rlestinian people. ${ }^{54}$

From this discussion of the state's compassionate, humanitarian façade as a mask for its violence, I want to return to Waltz with Bashir, which exemplifi s these elements in its cinematic treatment of the 1982 Sabra and Shatila massacre, when Lebanese Christian Phalangists killed thousands of Palestinians with the IDF's complicity. As mentioned in my opening, the film is constructed as victim trauma. It revolves aroundthe unknown nature of Folman's involvement in the massacre. While recovering his memories, he realises that he and other IDF soldiers illuminated the night sky with flares to facilitate it. Lurid amber flares form a leitmotif of his guilt, staining much of the film's colour palette. The verdict of the narrative, however, is reduced culpability: as his therapist tells us, Folman merely shone the flares; he did not carry out the massacre itself, and his excess guilt is a product of inherited Holocaust trauma, unielated to Sabra and Shatila.

In its fi al scene, the film imagines an encounter between Folman and Palestinian women from the refugee camps. Folman's eyes enlarge, implying alarm or sympathy with the suff ring before him. The sounds overlaid on their animated forms are real women's actual cries of grief, as the film segues into live-action archival news footage. As I have previously written,

Thelive footage is intended to confront audiences with an uncomfortable reality - it is the moment when, in the film's own analogy, 'the camera' breaks, preventing the possibility of dissociation or denial. Theuse of archive footage, with its indexical properties, imparts a revelation of 'truth' But, as we know ... news media do not signify unmediated 'truth ${ }^{55}$

The Palestinian women speak but, at least in the international print, their Arabic is not subtitled, which creates the perception that they are lost in theirgrief: a passive 
backdrop for an Israeli soldier's trauma. Withoutspeech, the women are turned into classic icons of suff ring, evoking a Christian tradition of suff ring motherhood ( pietà) frequently used in humanitarian images to invite pity. ${ }^{56}$ But these women do not want our pity; they want exposure and action. One of them advances towards the camera, demanding in Arabic: 'Film, film and deliver it to foreign countries.'

The ending replaces justice with compassion, which masks the Israeli army's violence, providing what is eff ctively an image of impunity, as the film surveys the bodies of innocents on the ground, closing into a little girls head in the rubble, before fading to black. Ths call for compassion dehistoricises Palestinians' collective politicalclaims and turns them into pathetic victims. It exemplifi s a form of perception management that I have been tracing through news coverage: acknowledge the tragedy, express sympathy and remorse, butblame others. Th s narrative of absolution of responsibility is as much about Israel's continuing actions against the Palestinians as it is about thepast.

\section{The different perspective offered by Where Should the Birds Fly}

Palestinians have challenged the perception management of mainstream media by creating their own images of both the destruction and everyday life in Gaza, in which they feature as agents and actors in their own narratives. Where Should the Birds Fly (2013) is a documentary by a Gazan citizen journalist, Fida Qishta, about the 2008-9 conflict. In her director's statement, she expresses her desire to narrate it from her own perspective:

In 2009, when Gaza was attacked, most internationals left. Th re were no journalists. The only people filming were from Gaza, myself included. But, because they weren't English speakers, others talked about theirfootage. I thought this wasn't fair I wanted to tell my own story. ${ }^{57}$

Where Should the Birds Fly confronts the official Israeli narrative about the war through its video testimony. During the film, Qishta describes her camera as a weapon, the onlyweapon she has against the attacks on the people of Gaza. She sent her footage to a US production company, Deep Dish TV, whichused crowdfunding to fi ance the film. Unlike Waltz with Bashir, Where Should the Birds Fly has not benefi ed from exposure at the most prestigious film festivals and a general theatrical release; however, it has become well-known by Palestine solidarity groups and human rights campaigners via its circulation in documentary and other specialist film festivals, community and university screenings, and online distribution.

At a time when Gaza is becoming increasingly inaccessible to the outsideworld hidden behind fortifi $\mathrm{d}$ fences as well as a media veil - metaphors about it have proliferated, as Helga Tawil-Souri and Dina Matar remark in their anthology Gaza as Metaphor. ${ }^{58}$ Where Should the Birds Fly takes its title from a line in a poem by the 
Palestinian writer MahmoudDarwish. ${ }^{59}$ Poetically rendering the experience of siege, the title breathes new life into the now familiar metaphor of Gaza as an 'open-air prison', conveying (in the film's context) that people are unable to fl e from the bombardment, despite the IDF's 'humanitarian' warnings, since they lack any safe place to fl e, surrounded as they are by heavily guarded land and sea borders. The birds metaphor in its title is emblematic of the film's diff rent use of animal imagery from Waltz with Bashir, where it serves to dehumanise the enemy, whether it be through the dogs, whose indefatigable chase and hellishly glowing amber eyes suggest a threatening and demonicaspect, or the majestic and pitiful 'Arabian horses'. Where Should the Birds Fly evokes smaller animals (birds, chickens, mice), using them, fi st, to express the vulnerability of Palestinians in the face of the oppressor and, second, to draw attention to how Palestinians are dehumanised in both news coverage and military practice.

Both Qishta's choices and those of her production company shape the film, which may be regarded as the esult of their omplex negotiation:

We had a lot of footage from the destruction caused by the Israeli attack. Both Brian [Drolet, the producer] and Gladys [Joujou, the editor] initially focused more on the war as a major part of the movie. For me, people's lives are more important than showing just destruction... Th re are so many parts of our lives that go unrecorded. And I had footage to document many of these invisible struggles. ${ }^{60}$

In contrast to news reports, where humanitarian concern about Palestinians declines once a fragile ceasefi e is declared, the film charts what happened before 'Cast Lead' and after. It captures the everyday violence that Gaza experiences at Israel's hands, along with Gazans' effo ts to live a nomal life - what Qishta calls their 'invisible struggles'. Criticising Hamas's tactics, she declares, in voiceover, 'All weapons strike fear into the hearts of people living under them. It doesn't matter if they are the relatively simple and ineff ctive rockets from Gaza into ... Israel or Israel's sophisticated US-made missiles launched from F-16s or Apache helicopters'. Her film imparts the bigger picture (missing from mainstream coverage) through its focus on the blockade and routine attacks by Israel of which the full-scale 'wars' are magnific tions.

We follow Qishta as shefilms farmers and fishermen trying to earn a living, accompanied by international observers, although the latter's presence is not always a safeguard. Themilitarised 'buff r zone', which penetrates three kilometres into the Gaza Strip in some places and absorbs 30 per cent of its arable land, prevents farmers from cultivating theirfi lds; when they approach the buff $\mathrm{r}$ zone they are shot at by IDF patrols. In one scene, fishermen are shown under fi e, as the Palestinian territorial waters in which they fish are policed by Israeli gunboats. The clatter of gunshots comes over the choppy sea. The picture of injustice - the Israeli navy shooting at unarmed Palestinians - is unmistakable. 'Why?' cries the international observer 
accompanying the fishermen. Thereply from the gunboat's loudhailer is merely that they are in 'a closed military area' and therefore must retreat. While threatening to shoot at the fishermen, the Israeli soldiers aim at the cables that attach the fishing nets to the boat; the cables eventually break, resulting inloss of the fishermen's catch.

Thefilmintimates the ubiquitous Israeli presence in Gaza, not just in moments of spectacular violence during military operations. Do the Israeli soldiers 'consciously intend' to deprive the fishermen of 'the ability to make a living and feed their families' asks Qishta in voiceover. Her film suggests the blockade purposefully creates unliveable conditions for Palestinians in Gaza, providing a striking contrast to news footage where Israel is portrayed as under siege and encircled by hostile attackers, threatened by 'infiltrators' and tunnels. It presents the opposite scenario: the colonised who are threatened and encircled by tanks on land and gunboats at sea, and with whose predicament we are urged to identify. We may be reminded of the parallels with the Native Americans as well as their ulimate fate.

In addition, Where Should the Birds Fly gives voice to a child survivor, a tenyear-old girl, Mona, in a way that partly diff rs from standard news and humanitarian images, such as the mute, unnamed girl with panda-like bruises on her eyes in Snow's 2014 video blog who, as discussed earlier, appears as a generic victim, lacking any agency of her own, instead becoming a means for Snow to express his own impassioned appeal. We fi st encounter Mona walking through the rubble in the aftermath of 'Cast Lead', pursued by Qishta with her camera. With her bold gaze at the camera and precocious responses to Qishta's questions, Mona seems to be endowed with the power to express herself, rather than having others speak on her behalf. At the same time, her quiet voice, slightly diffi nt demeanourand bandage over one eye designate her as a victim, fragile and weak. When asked how many people in her family died, she replies, 'not many, just my mother, my father, both my sisters-in law and my nephew'. We observe her delicate face as a register of her pain and studied indiff rence, as she self-consciously drains her testimony of emotion. As Lury writes, we often interpret a child's 'unreadable face' to fit our own agendas. ${ }^{61}$ In her pursuit of Mona, Qishta makes the child a vehicle for both her humanitarian and pditical concerns.

In the film, Mona is framed within a narrative of 'lost' or 'denied' childhood. ${ }^{62}$ She shows us her drawings of the attack on her family home. In these moments, the film pulls us into the child's perspective. Although Mona is capable of elucidating her drawings with astonishing verbal articulacy, the pictures remind us that she is a child, who sees the world diff rently from adults, interpreting it through shapes and colours, rather than through linguistic means. In one drawing, a huge heart encompasses her 'precious ones', her father and mother, now dead as a result of the attack. In another, a helicopter drops bombs on a house which catches fi e and is reduced to rubble. Two Israeli soldiers carrying machine guns stand nearby, while the dead lie on the gound. Mona remarks, "The sraeli soldiers were shooting at the people as if they were not human, as if they were chickens or mice. For the 
Israeli army this is withoutmeaning. But the victims were very preciousto us, even if they didn't consider them human'. Seeing through the child's perspective, the scene invites us to refl ct not onlyon the cruelty of the Gaza 'wars', butalso the perception management that facilitates them. Colonial violence operates by dehumanisation, as one can see in the Arabian horses and dogs of Waltz with Bashir. Theeff ct of this is that Palestinian lives can be disregarded in the pursuit of power, both by those perpetrating the violence and by those who support them. Caught up in the conflict, the child Mona figures in Where Should the Birds Fly not onlyas a traumatised victim and witness, but ako as an agent and spdkesperson for øcial justice.

\section{Conclusion}

Humanitarian images can limit our understanding by cultivating sympathy for Palestinians in Gaza as victims in need of international aid, separated from theirpolitical context. As I hope to have conveyed in this chapter, it is not enough to have sympathy but to refl ct on what makes such oppression possible, acceptable and 'nomal', including the international community's accommodation to an unjust political reality. Th s chapter has framed these issues through the notion of perception management, which influ nces how images of Palestinian suff ring are viewed and how blame is allocated. Perception management serves to prolong the conflict. As a result, the dispossession of Palestinians can be continued. Th s is why it is crucial to refl ct on the images and narratives that support the status quo; it may be a step towards changing it.

\section{Notes}

1 K. Lury, The Child in Film: Tears, Fears and Fairy Tales (London: I. B. Tauris, 2010), p. 105.

2 M. Curtis, Unpeople: Britain's Secret Human Rights Abuses (London: Vintage, 2004).

3 S. Chaudhuri, Cinema of the Dark Side: Atrocity and the Ethics of Film Spectatorship (Edinbuigh: Edinbuigh University Press, 2014), p 146.

4 B. Netanyahu, Interviewed by Wolf Blitzer, CNN, 20 July 2014, www.youtubecom/ watch? $\mathrm{v}=\mathrm{ZHg}$ AtlN5CZU. Accessed 10 September 2016.

5 P. Virilio, War and Cinema: The Logistics of Perception, trans. P. Camiller (London: Verso, 1989), p. 4.

6 Curtis, Unpeople, p. 101.

7 C. McGreal, 'Ban on Foreign Journalists Skews Coverage of Conflict', Guardian (10 January 2009), p. 8.

8 Tokyobk, User comment on 'Israeli strike kills four Palestinian children playing soccer on Gaza beach', 16 July 2014, http:// mondoweiss.net/2014/07/israelipalestinian-children/. Accessed 10 September 2016.

9 P. Pisters, 'Logistics of Perception 2.o: Multiple Screen Aesthetics in Iraq War Films', FilmPhilosophy, 14:1 (D10), p. 235

10 S. Robson, 'Harrowing Images Capture Palestinian Boys Fleeing Beach Moments Before TheyWere killed by Israeli Shell', Mirror, 17 July 2014, www.mirror.co.uk/news/ world-news/ harrowing-images-capture-palestinian-boys-3873689. Accessed 10 September 2016. 
11 J. Snow, Interview with Mark Regev, Channel 4 News, 16 July 2014, 7 p.m.

12 B. White, 'Introduction', in I. Hewitt (ed.), Israel and Gaza: Behind the Media Veil (London: Memo Publishers, 2015), p xvi.

13 P. Mason, 'Why Israel is Losing the Social Media War Over Gaza', 21 July 2014, http:// blogs. channel4.com/paul-mason-blog/impact-social-media-israelgaza-conflict/1182. Accessed 10 September 2016.

14 A. Peled, 'TheFirst Social Media War between Israel and Gaza', Guardian (6 December 2012), www.theguardian.com/media-network/media-network-blog/20 12/ dec/ 06/ first-socialmedia-war-israel-gaza. Accessed 10 September 2016.

15 A. Kuntsman and R. Stein, Digital Militarism: Israel's Occupation in the Social Media Age (Stanford: Stanford University Press, 2015). Alongside this, Kuntsman and Stein criticise the discourse of 'the fi st time, which conceals a longer history of the militarisation of online communities - developments that they track from 2000, including the IDF's use of YouTube and Twitter during the 2008-9 conflict.

16 Kuntsman and Stein,Digital Militarism, p. 69.

17 D. Kumar, “"Telegenically dead”: Israel's Crumbling Media War', 23 July 2014, http:// deepakumar.net/empire-bytes/telegenically-dead-israels-crumbling-media-war/. Accessed 10 September 2016.

18 J. Snow, 'TheChildren of Gaza', 27 July 2014, www.channel4.com/news/ the-children-of-gazajon-snow-video. Accessed 10 September 2016.

19 J. Deans, 'Jon Snow Video Backed by Channel 4', 31 July 2014, www.theguardian.com/media/ 2014/jul/31/jon-snow-gaza-video-backed-channel-4. Accessed 10 September 2016.

20 S. Sontag, Regarding the Pain of Others (London: Penguin, 2003), p. 91

21 Cited in Deans, 'Jon Snow Video Backed by Channel 4'.

22 W. Hesford, Spectacular Rhetorics: Human Rights Visions, Recognitions, Feminisms (Durham, NC and London: Duke University Press, 2011).

23 In another Channel 4 video posted on YouTube, recounting Snow's return journey to Gaza a year later, the girl - now physically recovered, though mentally traumatised - is named as Nema. See J. Snow, 'Children of Gaza: Jon Snow Meets the Victims', 9 July 20 15, www.youtube. $\mathrm{com} /$ watch? $\mathrm{v}=\mathrm{mSiwsk} 1 \mathrm{p} / \mathrm{BI}$. Accessed 10 September 2016.

24 D. Fassin, 'The Humanitarian Politics of Testimony: Subjectific tion through Trauma in the Israeli-Palestinian Conflict', Cultural Anthropology, 23:3 (2008), p. 537.

25 Fassin, The umanitarian Politics of Testimony', p. 535

26 S. Moeller, 'A Hierarchy of Innocence: The Media's Use of Children in the Telling of International News', The Harvard International Journal of Press/Politics, 7:1 (D02), p. 48.

27 Many Palestinians believe that Israel's purpose was to destroy, in a divide-and-conquer strategy, the Unity government formed by former rival Palestinian parties Hamas and Fatah in June 2014; it has also been suggested that oil and gas reserves off Gaza’s coast may have been an added incentive, since a functioning Palestinian state would impede Israel's possession and access.

28 G. Philo and M. Berry, More Bad News from Israel (London: Pluto Press, 2011), pp 379-80.

29 BBC, News at Ten, BBC 1, 29 July 2014, lo p.m.

30 United Nations Relief and Works Agency for Palestine (UNRWA), 'Where We Work: Gaza Strip' (2014), www.unrwa.org/where-we-work/gaza-strip. Accessed 10 September 2016.

31 J. Abu Salim, 'From Fence to Fence: Gaza’s Story in its Own Words', in H. Tawil-Souri and D. Matar (eds), Gaza as Metaphor (London: Hurst and Company, 2016), p. 84.

32 J. Berger, 'Introduction: Where Are We?' in D. Lévi-Strauss, Between the Eye: Essays on Photography and Politics (New York: Aperture, 2003), p xiii. 
33 S. Tal, Profile in 'Gaza Conflict: Contrasting Views on Targeting', 2014, www.bbc.co.uk/news/ world-28630442, emphasis mine Accessed 10 September 2016.

34 S. Dutton, J. de Pinto, A. Salvanto and F. Backus, 'Who Do Americans Sympathize with More: Israelis or Palestinians?’ CBS News, 6 August 2014, www.cbsnews.com/ news/who-do-americans-sympathize-with-more-israelis-or-palestinians/. Accessed 10 September 2016.

35 N. Ahmed, 'Cutting through Israeli Spin', in I. Hewitt (ed.), Israel and Gaza: Behind the Media Veil (London: Memo Publishers, 2015), p. 32.

36 A. Saleem, 'BBC’s Kafkaesque Response to Complaint Over Gaza Coverage', 23 December 2014, http:// electronicintifada.net/ blogs/ amena-saleem/bbcs-kafkaesque-response-complaintover-gaza-coverage. Accessed 10 September 2016.

37 Cited in C. Urquhart, 'Gaza on Brinkof Implosion as Aid Cut-OffStarts to Bite', Observer (16 April 2006), www.theguardian.com/world/2006/apr/ 16/ israel. Accessed 10 September 2016.

38 E. Weizman, The Least of All Possible Evils: Humanitarian Violence from Arendt to Gaza (London: Verso, 2011),p. 5.

39 Compared to other international conflicts, the number of direct or violent deaths in the IsraeliPalestinian conflict is not especially high. However, as Eyal Weizman writes, 'another, rather more subtle form of killing has become commonplace'. A calculated Israeli policy regarding Gaza, this takes place 'through degrading environmental conditions to aff ct the quality of water, hygiene, nutrition and healthcare; by restricting the $\mathrm{fl} \mathrm{w}$ of life-sustaining infrastructure, forbidding the importation of water purifi rs and much-needed vitamins (mainly B12), by restrictions on planning and by making it difficult for patients to travel. The Least of All Possible Evils, p. 86.

40 G. Agamben, Homo Sacer: Sovereign Power and Bare Life, trans. D. Heller-Roazen (Stanford: Stanford University Press, 1998), p. 133.

41 O. Guerin, 'Gaza Crisis: Inside Militants' Tunnd', News at Ten, BBC1, 29 July 2014, www.bbc. co.uk/news/ world-middle-east-28551448. Accessed 10 September 2016.

42 Abu Salim, 'From Fence to Fence', pp 90-1.

43 R. Stam and L. Spence, 'Colonialism, Racism, Representation: An Introduction', in B. Nichols (ed.), Movies and Methods, vol. 2 (Berkeley: University of California Press, 1985), p 637.

44 D. Aaronovitch, 'Why The Honourable Woman is the Year's Most Important Drama', The Times (7 August 2014), www.thetimes.co.uk/article/why-the-honoulable-woman-is-the-yearsmost-important-drama-bg0dktrh3h0 Accessed 10 September 2016.

45 'The Honourable Woman Episode 4 - TheRibbon Cutter' (2014), BBC2 Programmelisting, www.bbc.co.uk/programmes/b04bwqzv. Accessed 10 September 2016.

46 Amnesty International, Families Under the Rubble: Israeli Attacks on Inhabited Homes (London Amnesty International Ltd., 2014), p. 6.

47 N. Sultany, 'Repetition', in H. Tawil-Souri and D. Matar (eds), Gaza as Metaphor (London Hurst and Company, 2016), p. 207.

48 Weizman, The Least of All Possible Evils, p. 92.

49 G. E. Bisharat, 'Violence's Law: Israel's Campaign to Transform International Legal Norms', Journal of Palestine Studies, 42:3 (2013), pp 68-84.

50 Weizman, The Least of All Possible Evils, p. 121.

51 K. Wark, Interview with Dore Gold, Newsnight, BBC2, 28 July 2014, 10.30 p.m.

52 F. Luntz, The Israel Project's 2009 Global Language Dictionary (Washington, DC: The Israel Project, 2009), p. 4.

53 H. Arendt, Responsibility and Judgment, ed. J. Kohn (New York: Schocken Books, 2003), pp. 36-7. 
54 E. Weizman, Hollow Land: Israel's Architecture of Occupation (London: Verso, 2007), p. 175.

55 Chaudhuri, Cinema of the Dark Side, p. 156.

56 See V. Gorin, 'An Iconography of Pity and a Rhetoric of Compassion: War and Humanitarian Crises in the Prism of American and French News Magazines (1967-95)', in J. Seethaler, M. Karmasin, G. Melischek and R. Wöhlert (eds), Selling War: The Role of the Mass Media in Hostile Conflict from World War I to the 'War on Terror' (Bristol: Intellect, 2013), p. 140.

57 F. Qishta, 'Interview with Director Fida Qishta', in Where Should the Birds Fly Presskit (2013), p. 5, http:// whereshouldth birdsfly.org/documents/WSTBFPressKit_09-05-2013.pdf. Accessed 10 September 2016.

58 H. Tawil-Souri and D. Matar (eds), Gaza as Metaphor (London: Hurst and Company, 2016).

59 M. Darwish, 'TheEarth is Closing on Us', in Adoni, M. Darwish and S. al-Qasim, Victims of a Map: A Bilingual Anthology of Arabic Poetry, trans. A. al-Udhari (London: Al Saqi Books, 1984), p. 13.

60 Qishta, 'Interview with Director Fida Qishta', p. 5.

61 Lury, The Child in Film, p. 109.

62 K. Wells, 'Narratives of Liberation and Narratives of Innocent Suff ring: TheRhetorical Uses of Images of Iraqi Children in the Bitish Press', Visual Communication, 6:1 (2007), p. 59.

\section{References}

Aaronovitch, D., 'Why The Honourable Woman is the Year's Most Important Drama', The Times (7 August 2014), www.thetimes/co.uk/article/why-the-honounable-woman-is-the-years-mostimportant-drama-bg0dktrh3h0 Accessed 10 September 2016.

Abu Salim, J., 'From Fence to Fence: Gaza's Story in its Own Words', in H. Tawil-Souri and D. Matar (eds), Gaza as Metaphor (London: Hurst and Company, 2016), pp. 83-93.

Agamben, G., Homo Sacer: Sovereign Power and Bare Life, trans. D. Heller-Roazen (Stanford: Stanford University Press, 1998).

Ahmed, N., 'Cutting through Israeli Spin', in I. Hewitt (ed.), Israel and Gaza: Behind the Media Veil (London: Memo Publishers, 2015).

Amnesty International, Families Under the Rubble: Israeli Attacks on Inhabited Homes (London Amnesty International Ltd., 2014), www.amnestyusa.org/research/reports/families-underthe-rubble-israeli-attacks-on-inhabited-homes. Accessed 10 September 2016.

Arendt, H., Responsibility and Judgment, ed. J. Kohn (New York: Schocken Books, 2003).

Berger, J., 'Introduction: Where Are We?' in D. Lévi-Strauss, Between the Eye: Essays on Photography and Politics (New York: Aperture, 2003), pp vii-xv.

BBC, News at Ten, BBC 1, 29 July 2014, lo p.m.

Bisharat, G. E., 'Violence's Law: Israel's Campaign to Transform International Legal Norms', Journal of Palestine Studies, 42:3 (2013), pp 68-84.

Chaudhuri, S., Cinema of the Dark Side: Atrocity and the Ethics of Film Spectatorship (Edinbuigh: Edinbuigh University Press, 2014).

Curtis, M. Unpeople: Britain's Secret Human Rights Abuses (London: Vintage, 2004).

Darwish,M., 'TheEarth is Closing on Us', in Adons, M. Darwish andS. al-Qasim,Victims of a Map: A Bilingual Anthology of Arabic Poetry, trans. A. al-Udhari (London: Al Saqi Books, 1984), p. 13.

Deans, J. 'Jon Snow Video Backed by Channel 4', 31 July 2014, www.theguardian.com/media/ 2014/jul/31/jon-snow-gaza-video-backed-channel-4. Accessed 10 September 2016.

Dutton, S., J. de Pinto, A. Salvanto and F. Backus, 'Who Do Americans Sympathize with More: Israelis or Palestinians?' CBS News, 6 August 2014, www.cbsnews.com/news/whodo-americans-sympathize-with-more-israelis-or-palestinians/ . Accessed 10 September 2016. 
Fassin, D., 'The Humanitarian Politics of Testimony: Subjectific tion through Trauma in the Israeli-Palestinian Conflict', Cultural Anthropology, 23:3 (2008), pp. 531-58.

Gorin, V., 'An Iconography of Pity and a Rhetoric of Compassion: War and Humanitarian Crises in the Prism of American and French News Magazines (1967-95)', in J. Seethaler, M. Karmasin, G. Melischek and R. Wöhlert (eds), Selling War: The Role of the Mass Media in Hostile Conflict from World War I to the 'War on Terror' (Bristol: Intellect, 2013), pp 135-56.

Guerin, O., 'Gaza Crisis: Inside Militants' Tunnd', News at Ten, BBC1, 29 July 2014, www.bbc. co.uk/news/ world-middle-east-28551448. Accessed 10 September 2016.

Hesford, W., Spectacular Rhetorics: Human Rights Visions, Recognitions, Feminisms (Durham, NC and London: Duke University Press, 2011).

'The Honourable Woman Episode 4 - The Ribbon Cutter' (2014), BBC2 Programme listing, www.bbc.co.uk/programmes/b04bwqzv. Accessed 10 September 2016.

Kumar, D., “'Telegenically dead”: Israel's Crumbling Media War', 23July 2014, http:// deepakumar.net/ empire-bytes/telegenically-dead-israels-crumbling-media-war/ . Accessed 10 September 2016.

Kuntsman, A. and R. Stein, Digital Militarism: Israel's Occupation in the Social Media Age (Stanford: Stanford University Press, 2015).

Luntz, F., The Israel Project's 2009 Global Language Dictionary (Washington, DC: The Israel Project, 2009), www.webcitation.org/ query? url=http\%3A\%2F\%2www.newsweek.com\%2 Fmedia\%2F70\%2Fip_report.pdf\&date=2009-08-06\%3Cbr\%3E Accessed 10 September 2016.

Lury, K., The Child in Film: Tears, Fears and Fairy Tales (London: I. B. Tauris, 2010).

McGreal, C., 'Ban on Foreign Journalists Skews Coverage of Conflict', Guardian (10 January 2009), p. 8.

Mason, P., 'Why Israel is Losing the Social Media War Over Gaza', 21 July 2014, http:// blogs. channel4.com/paul-mason-blog/impact-social-media-israelgaza-conflict/1182. Accessed 10 September 2016.

Moeller, S., 'A Hierarchy of Innocence: TheMedia's Use of Children in the Telling of International News', The Harvard International Journal of Press/Politics, 7:1 (D02), pp. 36-56.

Peled, A., 'The First Social Media War between Israel and Gaza', Guardian (6 December 2012), www.theguardian.com/media-network/media-network-blog/2012/ dec/ 06/ first-socialmedia-war-israel-gaza. Accessed 10 September 2016.

Philo, G. and M. Berry, More Bad News from Israel (London: Pluto Press, 2011).

Pisters, P., 'Logistics of Perception 2.o: Multiple Screen Aesthetics in Iraq War Films', FilmPhilosophy, 14:1 (D10), pp. 232-51.

Qishta, F., 'Interview with Director Fida Qishta', in Where Should the Birds Fly Presskit (2013), pp. 4-5, http:// whereshouldthebirdsfl .org/documents/WSTBFPressKit_09-05-2013.pdf. Accessed 10 September 2016.

Robson, S., 'Harrowing Images Capture Palestinian Boys Fleeing Beach Moments Before They Were Killed by Israeli Shell', Mirror, 17 July 2014, www.mirror.co.uk/news/world-news/ harrowing-images-capture-palestinian-boys-3873689. Accessed 10 September 2016.

Saleem, A., 'BBC's Kafkaesque Response to Complaint Over Gaza Coverage', 23 December 2014, http:// electronicintifada.net/blogs/amena-saleem/bbcs-kafkaesque-response-complaintover-gaza-coverage. Accessed 10 September 2016.

Sontag, S., Regarding the Pain of Others (London: Penguin, 2003).

Snow, J., Interview with Mark Regev, Channel 4 News, 16 July 2014, 7 p.m.

Snow, J., 'TheChildren of Gaza', 27 July 2014, www.channel4.com/news/ the-children-of-gaza-jonsnow-video. Accessed 10 September 2016.

Snow, J., 'Children of Gaza: Jon Snow Meets the Victims', 9 July 2015, www.youtubecom/ watch? $\mathrm{v}=\mathrm{mSiwsk} 1 \mathrm{p} / \mathrm{BI}$. Accessed 10 September 2016. 
Stam, R. and L. Spence, 'Colonialism, Racism, Representation: An Introduction', in B. Nichols (ed.), Movies and Methods, vol. 2, Berkeley: University of California Press, 1985), pp. 632-49.

Sultany, N., 'Repetition', in H. Tawil-Souri and D. Matar (eds), Gaza as Metaphor (London: Hurst and Company, 2016), pp. 203-17.

Tal, S., Profile in 'Gaza Conflict: Contrasting Views on Targeting', 2014, www.bbc.co.uk/news/ world-28630442. Accessed 10 September 2016.

Tawil-Souri, H. and D. Matar (eds), Gaza as Metaphor (London: Hurst and Company, 2016).

Tokyobk, User comment on 'Israeli strike kills four Palestinian children playing soccer on Gaza beach', 16 July 2014, http:// mondoweiss.net/ 2014/07/israeli-palestinian-children/. Accessed 10 September 2016.

United Nations Relief and Works Agency for Palestine(UNRWA), 'Where We Work: Gaza Strip' (2014), www.unrwa.org/where-we-work/gaza-strip. Accessed 10 September 2016.

Urquhart, C., 'Gaza on Brink of Implosionas Aid Cut-OffStarts to Bite', Observer (16 April 2006), www.theguardian.com/world/2006/apr/ 16/israel. Accessed 10 September 2016.

Virilio, P., War and Cinema: The Logistics of Perception, trans. P. Camiller (London: Verso, 1989).

Wark, K., Interview with Dore Gold, Newsnight, BBC2, 28 July 2014, 10.30 p.m.

Weizman, E, Hollow Land: Israel's Architecture of Occupation (London: Verso, 2007).

Weizman, E., The Least of All Possible Evils: Humanitarian Violence from Arendt to Gaza (London Verso, 2011).

Wells, K., 'Narratives of Liberation and Narratives of Innocent Suff ring: The Rhetorical Uses of Images of Iraqi Children in the British Press', Visual Communication, 6:1 (2007), pp. $55-71$

White, B., 'Introduction', in I. Hewitt(ed.), Israel and Gaza: Behind the Media Veil (London: Memo Publishers, 2015), pp x-xvii. 


\title{
6 \\ The Unknown Famine: Television and the politics of British humanitarianism
}

\author{
Andrew Jones
}

Themass media is a critical actor in the global humanitarian system. New communication technologies have publicised and drawn attention to disasters and faraway suff ring, collapsing the distance between global North and South,mobilising public empathy and accelerating the growth of international NGOs. ${ }^{1}$ Thelinkages between humanitarianism and the media have been analysed from a range of perspectives, with many scholars focusing on the nexus between media representations of human suff ring, international NGOs, donor publics and policymakers. While this literature has advanced our understanding of the dynamics of humanitarian action, it has predomimantly focused on the contemporary epoch. Th re is still much we do not fully understand about how interactions between specific humanitarian actors and media institutions originated and developed over a sustained length of time, despite an ongoing boom in historical studies of humanitarianism and NGOs. ${ }^{2}$ Th re is a pressing need for sustained historical research into the humanitarianism-media relationship, to shed new light on familiar debates and set out more rigorously how the contemporary aid indutry evolved.

Th s chapter undertakes such an analysis, focusing on how television coverage of major disasters in the global South shaped the historical and political trajectory of humanitarian aid in Britain. The chapter does so through a case study of British television coverage of a deadly famine in Ethiopia in 1973 , which despite causing a huge number of fatalities had gone unreported in the Western media. The famine was suddenly exposed in October 1973 by a single British television documentary, aired as part of ITV's current affai s series This Week under the title The Unknown Famine: A Report on Famine in Ethiopia. Presented by popular journalist Jonathan Dimbleby, the film captured graphic scenes of masses of starving Ethiopian peasants at a relief campin the north of the country. Theshocking images were overlaid with Dimbleby's sparse yet poignant narration, which emphasised the sheer magnitude of the disaster and the need for immeliate assistance.

Aired at a time when British viewers were limited to a choice of only three televisionchannels, The Unknown Famine was watched by an audience of over ten million 
people and triggered an immediate outpouning of mass emotion. ${ }^{3}$ The film was repeated on ITV and the BBC, screened at the House of Commons, and shown by television stations across Europe and the Commonwealth. The documentary's massive impact spurred donations to the largest humanitarian NGOs, while galvanising government officials into taking action. Dimbleby's film also had signific nt political consequences inside Ethiopia, as opposition movements utilised its shocking images of starvation to mobilise against and overthrow Emperor Haile Selassie's imperial government. ${ }^{4}$ Yet despite its importance, The Unknown Famine and the mobilisations that followed it have been largely neglected in studies of humanitarianism and media culture, being overshadowed by the larger-scale Ethiopian famine of $984-5$, which sparked the iconic Band Aid/Live Aid phenomenon ${ }^{5}$

Th s case study draws on a range of British media, NGO and governmental archival sources. Thecentral argument is that The Unknown Famine shaped the trajectory of British humanitarianism in three important ways, which are discussed in three corresponding analytical sections. First, the film provided an empathic demonstration of the power of televised images of human suff ring to mobilise the public, at a time when television coverage of overseas events was coming into its own and supplanting the popular press as a leading medium As the fi st section discusses, this generated substantial funds in donations for the largest NGOs while consolidating their links with television broadcasters. Second, The Unknown Famine and its aftermath was an important signpost for wider critiques of media representation and disaster fund raising imagery emerging withinthe aid community. As the second section sets out, Dimbleby and ITV framed the crisis in a specific way, focusing on simplistic messages of disaster and obscuring the more complex causes and political dimensions of African famine. In doing so, the film helped consolidate the use of 'negative' images of suff ring at the very moment that several prominent NGOs were growing uncomfortable with the eff cts of such images on public perceptions of the glbal South.

Thi d, the film's popular impact contributed towards signific nt changes in the British government's approach to disaster relief policy. During the late 1960s and early 1970s, Britain had struggled to adequately respond to a succession of major emergencies in Africa and Asia. Media coverage of Ethiopia brought further pressure to bear on policymakers, as the government was widely criticised for failing to react to the famine until it was too late. Th s criticism accelerated longer-running trends and helped bring about an overhaul of the British state's capacity for humanitarian aid, permanently raising the signific nce of disaster relief within policymaking. It is ultimately concluded that, despite the many profound changes that have reshaped both the global mass media and the humanitarian aid fi ld since the early 1970s, several of the dilemmas and issues raised by this case study remain pertinent to our understanding of the relationship between NGOs and television, the popular appeal of 'negative' images of African suff ring, and the enduring tensions between fundraising and education within the irternational aid sector. 


\section{The power of television}

Th re is a long history of faminein Ethiopia and the Horn of Africa. TheEthiopian famineof 1973-5 was protracted and severe, aff cting millions of people and causing an estimated 250,000 deaths. ${ }^{6}$ The famine was primarily the result of long-term drought, which caused desertific tion and crop failure across the Sahelian region of Africa in the late 1960s and early 1970s. Livestock was decimated, and millions were exposed to hunger, thirst and disease. The impact of the drought inside Ethiopia was aggravated by chronic poverty and inadequate infrastructure. Crucially, the famine was also exacerbated by the ineff ctive political response of Haile Selassie's government, which failed to acknowledge the true extent of the crisis or competently respond to the growing number of victims. International donors failed in their obligations by refusing to intervene or speak out against the Ethiopian monarchy, which was an impotant Western Cold Warally.

Western publics knew little of Ethiopia, a remote nation in the Horn of Africa which had largely avoided formal European colonialism. Humanitarian organisations also lacked a presence in the region, and international NGOs were unaware of the true situation inside Ethiopia for most of 1973 One notable actor on the ground was the Christian Relief and Development Association (CRDA), an umbrella body of Ethiopian churches and missionaries. TheCRDA was set up in May 1973 by Father Kevin Doheny, a veteran Irish Catholic missionary and relief worker. ${ }^{8}$ The CRDA publicised the famine and appealed for funds from European churches, and it was through the CRDA that some European NGOs (including Oxfam) came to learn of the unfolding disaster. However, it was not until UNICEF conducted a survey inside the country in August that the true extent of the suff ring became known. ${ }^{9}$ Oxfam (one of the fi st donors to CRDA) subsequently despatched Tony Hall, its 'publicity man in Africa', to the famine zones. Hall reported back on 'towns along Ethiopia's main road where people have been dying in tens and twenties every day for months. ${ }^{10}$ Hall also sent a series of articles and photographs to the British press in the hopes of generating media interest at home, with little success. Hall later commented that 'the news gatekeepers on this occasion could not give the story prominence ... the crisis quota had been filled ... We had failed to catch the nave." ${ }^{11}$

During the same period, British journalist Jonathan Dimbleby (son of famous broadcaster Richard Dimbleby) received rumous of a great famine from Ethiopian students via an intermediary. Dimbleby had recently joined ITV's flagshipcurrent affai s series This Week as a reporter and presenter. This Week had been runnirg since 1956, and by the 1970s the programme had developed a distinct joumalistic ethos grounded in social democratic values, committed to objectivity, with a reputation for professionalism. ${ }^{12}$ Dimbleby started with This Week in 1972, and became interested in African development issues after presenting a documentary on the Sahelian drought in June $1973{ }^{13}$ Dimbleby and a small crew travelled to Ethiopia in September to film a programme on the famine, receiving permission from the Ethiopian authorities 
to film on the condition that they referred to 'the problem of drought' rather than an outright 'disaster'. Dimbleby and his colleagues stayed for fourteen days, during which time they met with Father Kevin Doheny and other aid workers, and filmed footage at a relief camp in Dessie in nothern Ethiopia. ${ }^{14}$

All of the This Week crew were profoundy aff cted by the horrific scenes of mass starvation they encountered. Dimbleby later described the famine as an 'unspeakable horror' which 'fundamentally marked' his life. The team were accompanied by an official minder from the Ethiopian government, who was also so shocked by the tragedy that he permitted them to film without restrictions. ${ }^{15}$ Having captured the necessary footage Dimbleby and his staff then returned to Britain, clandestinely smuggling the raw film out of the country due to fears of it being confiscated. ${ }^{16}$ The footage was subsequently edited and produced into a half-hour documentary, broadcast by ITV on $\mathbf{8}$ October to a primetime audience.

Thefilm is an exceptionally powerful piece of broadcast journalism, skilfully shot and produced for maximum impact. The documentary opens with a wide angle tracking shot, which gradually moves along rows of stationary Ethiopian peasants. Thescene is domimated by large numbers of visibly malnounished men and women of all ages, sat listlessly and quietly on the dusty ground of the Dessie relief camp. At over two minutes in length the sequence is deliberately slow, conveying to the viewer the sense of an unending mass of suff ring people. The shot itself was achieved by simply having cameraman Ray Siemann walk slowly between the long lines of exhausted Ethiopians with his camera held low. ${ }^{17}$ Dimbleby's narration accompanying the shot is sparse yet captivating, his voice subtlycracking with emotion as he states: 'this is a queue for food. Th se people are Ethiopian peasants. Once they had cattl , land and houses. They sold them all to buy food. Now they have only their rags; they're destitute'. Dimbleby goes on to describe in drawn-out detail the hardships of daily life at the camp, observing 'two handfuls of boiled wheat in the moming, and a piece of bread in the afternoonkeeps them from death, no more ... these men, women and children have been like this now surviving, not living, for six months'. Th s narration methodically constructs for the audience the impression of a land where destitution and death are not only widespread, but have become a normal part of everyday life. As Dimbleby states, 'these people are now without hope. The 've seen mothers and fathers and sons and daughters, weaken and die. Now family by family they await the sme end'.

The powerful opening shot is followed by an extended discussion between Dimbleby and one of the few medical professionals at Dessie, concerning the weakened condition of children at the camp. At one point during the interview, the medic highlights visually and describes for the camera the diff rent conditions of specific infants in turn, stating: 'this infant is skinny and dry, mildly dehydrated ... [pointing to a young girl] she is suff ring from protein calorie malnutrition ... [moving to a young boy] if he doesn't get the necessary feeding, of course he will die ... [highlighting a diff rent young boy] he is almost a skeleton, he hasn't got the 


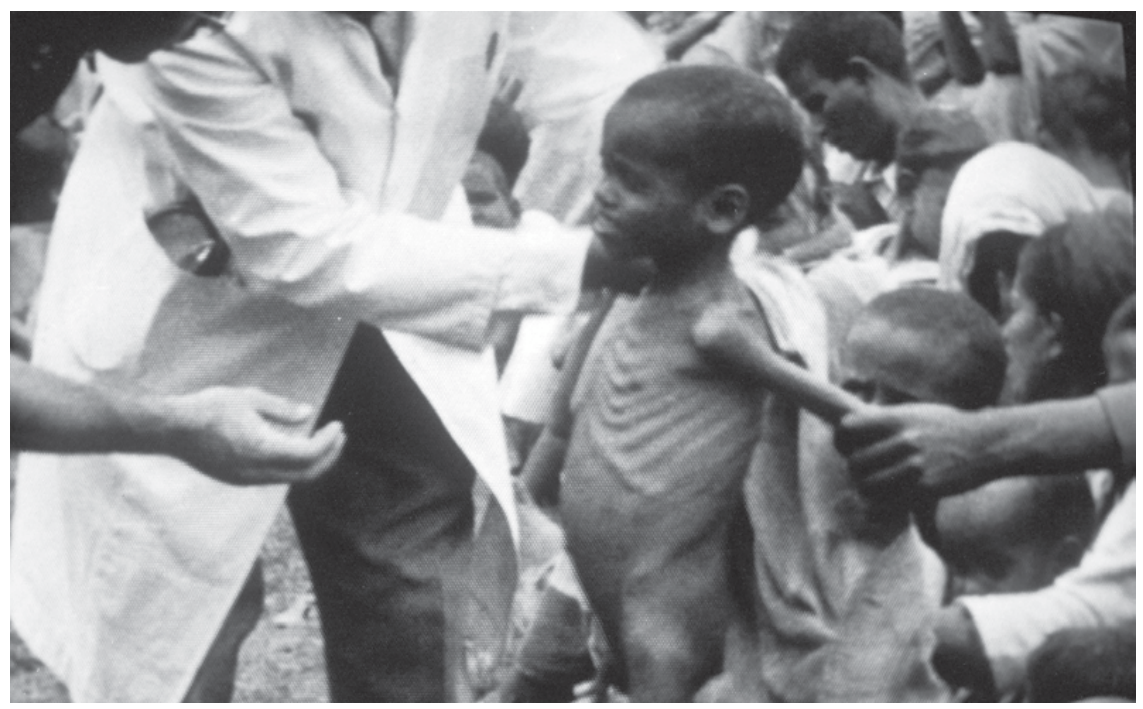

Figure 6.1 This Week: The Unknown Famine TX 1973

necessary muscles and $\mathrm{fl} \mathrm{sh} . .$. he is almost skin and bones' (see figures 6.1 and 6.2). The focus on these children roots the depersonalised opening sequence in specific individuals, and heightens the fatalistic tone underpinning thefilm.

As the film progresses Dimbleby's narration continues to describe life at Dessie in excruciating detail, focusing more and more on the plight of the children. As he remarks to the audience, 'babies are born here, to mothers too malnounished to feed them. Without the potein they ned, their clances of survival is remote'. Ths commentary is accompanied by graphicand unyielding shots of starving children crying out in visible pain. In one scene the camera lingers on a huddle of sick children receiving rudimentary medical care, as Dimblebybluntly states 'these seventeen children will die. Towards the end of the programme a stockpile of motionless bodies is shown, most of whom appear to be young infants. A Catholic monkworking at the camp informs Dimbleby that they all perished from starvation 'between twelve o'clock last night and six o'clock this moming. The film fi ally concludes with a direct plea by Dimbleby to the audience for immeliate international assistance:

Th s is the fi st time that the government of Ethiopia has allowed the outsideworld to witness this catastrophe. For six months now it has remained a secret. The delay was fatal for thousands of people. The situation was out of control. But the government does now desperately seek the help of the outside world. Relief is now under way, but much more is needed. Th se people need medicine, doctors and nurses, supplies, blankets and clothes, and above all, they need protein and milk and corn, and they need these right now. ${ }^{18}$ 


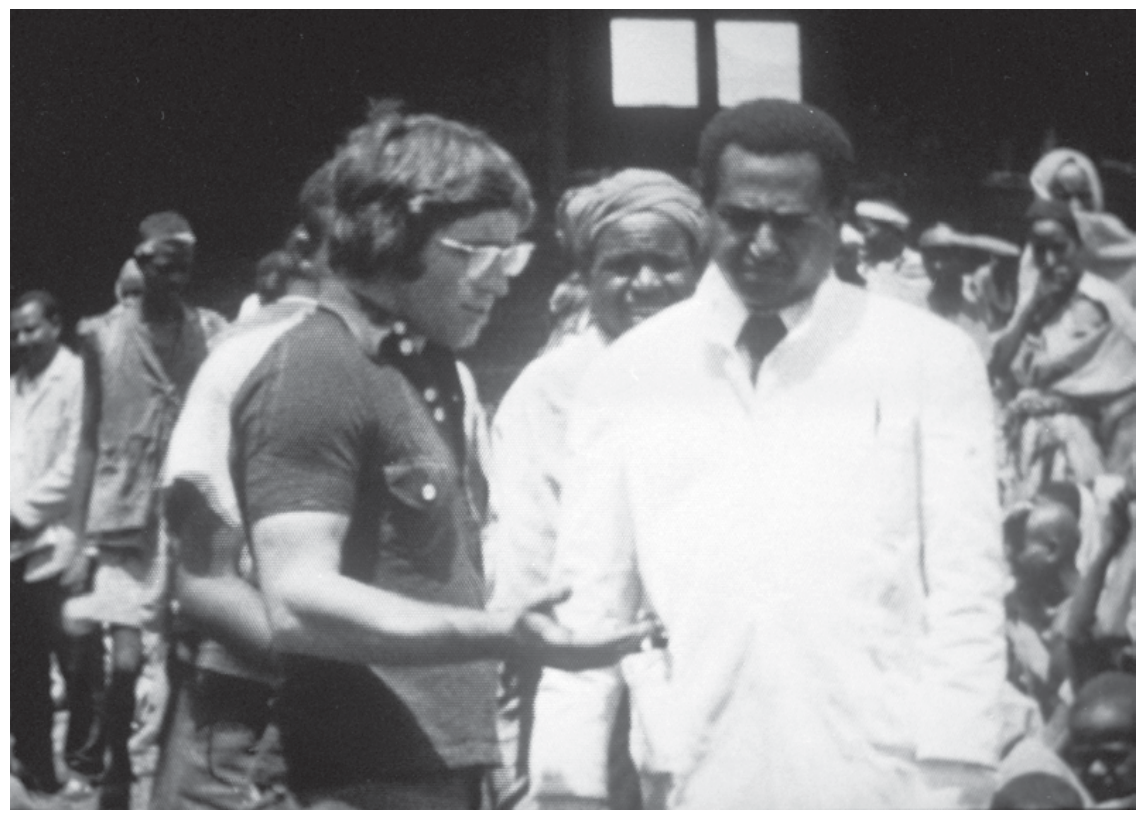

Figure 6.2 This Week: The Unknown Famine TX 1973

The Unknown Famine was watched at the time of broadcast by an estimated twelve million viewers, and the shocking scenes it depicted had an immediate impact upon many of thoe who tuned in. The I V phone switchboards were jammed as soon as the programme ended with callers wishing to help. ${ }^{19}$ The popular press picked up and ran with the story, carrying articles and photographs and launching fundraising appeals. The documentary was screened at the House of Commons, which the Shadow Minister for Overseas Development (Judith Hart) used to criticise the government and call for greater official aid. The film was also disseminated across Europe and the Commonwealth, having similar eff cts upon audiences wherever it was aired. Oxfam summarised that the documentary aroused popular concern 'fi st in Britain, and later in Canada, New Zealand, Australia, Holland, Belgium, Germany, Ireland, Sweden, Denmark and Italy. ${ }^{20}$ Concerned viewers in Britain naturally looked towards the largest humanitarian NGOs to take action on their behalf. Oxfam's phone switchboards were jammed after The Unknown Famine aired, with many callers reported as being 'near tears' and reacting with 'uncontrolled emotion. ${ }^{21}$ Seemingly overnight, the Ethiopian famine had been transformed from an unreported African disaster into a major domestic issue, and the public expected an immediate response.

British NGOs had littleinvolvement in the making of The Unknown Famine, and had not anticipated the media frenzy that followed. Theleading agencies responded 
by hastily opening a public appeal for donations through the Disasters Emergency Committee (DEC). TheDEC had been created a decade earlier as an umbrella body for what were then the fi e largest and most influ ntial organisations in the humanitarian sector: the British Red Cross, Christian Aid, Oxfam, Save the Children and War on Want. The DEC was founded to co-ordinate its members' responses to major disasters, to share information and avoid competition or duplication. Crucially, the DEC was also granted exclusive arrangements with the two British television broadcasters (BBC and ITV) to make emergency appeals to the public on primetime television after major disasters. Th se appeals were produced by $\mathrm{BBC}$ specialists working from scripts and material provided by the Committee. Any donations generated from these appeals were then allocated amongst its members, to spend on relief programmes in the aff cted regions. The DEC was thus a unique and important actor in the British humanitarian world, with a level of access to television that was unpecedented for the entire voluntary sector. ${ }^{22}$

Within a week of The Unknown Famine being aired, the DEC had requested and been granted a primetimetelevisionslot to appeal to the general public. Theappeal was presented by Jonathan Dimbleby, and consisted of powerful scenes and clips recycled from the documentary. The broadcast was also accompanied by an advertising campaign in the popular press. The appeal quickly set a new British fundraising record of $£ 1.5$ million(£16.4 millionin2015prices). Th s funding was allocated amongst the DEC membership, which had grown from fi e to six shortly before the appeal following the admission of the Catholic Fund for Overseas Development (CAFOD). ${ }^{23}$ The individualorganisations used these funds to support relief and development programmes not only inside Ethiopia, but across the Sahelian belt of Africa. Th s was a deliberate decisionon the part of the member agencies, who worded the appeal to be for 'victims of the doughts in Hhiopia and the ountries in the Shelian zone. ${ }^{24}$

Jonathan Dimbleby and This Week went on to receive multiple awards and accolades for the documentary, including the British Academy of Film and Television Arts (BAFTA) Richard Dimbleby Award for Outstanding Presenter in the Factual Arena in $1974 .{ }^{25}$ The Unknown Famine was undoubtedly one of the most influ ntial British television programmes of the 1970s. The film was also a compelling demonstration of the unrivalled power of television images of distant human suff ring to provoke an emotional response from the general public. Thefilm and its accompanying publicity generated an estimated $£ 15$ million in total donations from publics in Britain, Ireland and Western Europe, amounting to over $£ 160$ million in 2015 prices. ${ }^{26}$ Th s was not an unprecedented phenomenon - indeed, one of the factors behind the creation of the DEC a decade earlier was the realisation amongst mainline NGOs that televised emergency appeals could reach massive potential audiences. ${ }^{27}$ Television news reports had also played an increasingly important role in publicising major disasters in the immediate years prior to 1973 , including the Nigerian Civil War in 1968 and the East Pakistan crisis of 1970-1 (the latter of which led to the independence of Bangladesh). 
Yet for many observers, The Unknown Famine was an exceptional illustration of how a single piece of television reporting could transform an invisible 'third world' emergency into an international cause célèbre with signific nt domestic political consequences. ITV interpreted the film as a new phenomenon in broadcasting, where 'a disaster fails to make the news headlines and instead hits the public through a single documentary'. Stunned by the huge public response to Dimbleby's film, the broadcaster called for new production procedures which wouldensure they were in 'a better position to respond to suchoutcomes in future. One proposed method was 'relaxing the controls' on broadcast appeals, to explicitly link programmes such as The Unknown Famine with a DEC appeal at the time of broadcast (and thus provide an immediate outlet for public compassion). To do so required closer collaboration between the broadcasters and the DEC, and television companies and joumalists were subsequently required to consult with both bodies in advance if they were producing current affais programmes or reports on overseas disasters. ${ }^{28}$ Th $\mathrm{s}$ resulted in a closer symbiosis between the television broadcasters and the NGOs represented on the DEC, which consolidated the latter as the most influ ntial actors in their sector. The perception of the film as a new phenomenon in broadcasting also foreshadowed what would become a familiar trend in global humanitarianism, of single television news bulletins or programmes galvanising massive international public responses. Th s reality was not lost on the largest aid agencies, and it soon became accepted wisdom withinthe sector that emergency fundraising was 'next to impossible' without elevision coverage. ${ }^{29}$

\section{Representing famine}

The Unknown Famine was a profoundly moving doamentary for many who viewed it. Indeed, it is unlikely that many of the film's more shocking scenes of children would be approved for broadcast today. ${ }^{30}$ Dimbleby and his colleagues wanted to capture the attention of the public, and communicate the full scale of the disaster through uncompromising footage of the relief camps. However, the documentary also omitted any discussion of the politics of famine, with Dimbleby's narration providing no explanation or underlying causes for how the disaster had happened beyond vague references to drought. The political failures of both the Ethiopian government and the international community were also not acknowledged, beyond Dimbleby's veiled remarks at the conclusionof the programme. Th s was a deliberate decision by Dimbleby and the film's producer John Edwards, who felt that to adopt an 'accusatory' tone would lead to 'the impact of the horror' being 'diminished.' In a recent interview, Dimbleby commented that he 'didn't do politics, didn't say [the famine] was being suppressed ... I was only concerned that people should know what has happened.' He added that he 'was sure that was the right decision... otherwise it would have turned the film into my judgement on Ethiopia, rather than reporting on a errible situation. ${ }^{32}$ 
The DEC organisations adopted a similar frame for their subsequent broadcast appeal. Ths was perhaps inevitable, given that the appeal re-used clips from The Unknown Famine and was presented by Dimbleby. The voiceover narration accompanying the appeal emphasised the magnitude of the disaster, stating that in one area alone, 150,000 are thought to have died since the drought fi st tookeff ct backin April'. Theappeal also emphasised that the simple act of donating moneycould directly alleviate this suff ring, declaring 'this is what you can do to help: give money. That's the quickest, kindest way you can help over two million people in Ethiopia and the Sahel now on the erge of starvation. ${ }^{33}$

Like the original film, the DEC appeal made no reference to the man-made causes of famine, or the political complexities of providing aid in the region. Thelatter were particularlyacute, as there were seriouslogisticalobstacles and transport bottl necks to co-ordinating aid across the Sahel and the Horn of Africa. In Ethiopia these challenges were compounded by the lack of adequate administrative machinery or transport infrastructure, and all of the DEC members struggled to eff ctively spend theirshares of the appeal funds. In early 1974 Oxfam acknowledged that the agencies were 'open to severe criticism ... the international media and general public are not going to be impressed by the apparent lack of concrete action to relieve eff ctively the drought situation' ${ }^{34}$ Th s lack of 'concrete action' was in starkcontrast to the simplistic messages of philanthropy and salvation beirg communicated to the general public.

Simplifying disasters in this way was the established nom for the DEC. The Committee had made thirteen televised emergency appeals during the decade prior to 1973 all of which confomed to similar aesthetic conventions: foregrounding powerfulimages ofhuman suff ring (usually children), accompanied withguilt-laden narratives designed to tug on the heartstrings of those who viewed them and prompt a monetary donation. None of the appeals provided any information of substance concerning the political causes underlying such disasters, and many actively sought to prevent such discussion. As a DEC appeal forVietnam in 1967 stated: 'No politics. No boundaries. Send us moneynow. ${ }^{35}$ Th s method of representation was typical for humanitarian actors during this period, who gravitated towards using hard-hitting visual images of vulnerable children in their communications as the most eff ctive way to raise money A signific nt body of scholarshiphas since implicated this form of representation in reproducing colonial discourses and stereotypes of the global South as helpless, passive, infantile and dependent upon the civilised North for assistance. ${ }^{36}$ Such images thus fit into a longer lineage of child-centric charitable appeals dating back to missionaries and philanthropists in the colonial era, who used suff ring children as symbolic objects of unirersal concern. ${ }^{37}$

Ths depiction of the global South became ubiquitous in the Western media during the 1960s. Decolonisation drew new attention to hunger and poverty in the emerging 'third world', and images of starving children were widely disseminated in NGO appeals and television news reports of overseas disasters. ${ }^{38}$ In 1968 , media images of starving children aff cted by the ongoing Nigerian Civil War gave rise to 
huge public demands for intervention across the Western world. Tony Vaux refers to Nigeria as the 'fi st humanitarian disaster to be seen by millions of people.39 The stereotypical image of the starving African child was thus elevated into a 'universal icon of human suff ring' during this period. ${ }^{40}$ The Ethiopian famine may have been 'unknown', but its depiction on British televisionand reception by the general public fi ed into a broader framework for viewing and encountering the glbal South.

Crucially, simplistic media images and messages about the famine concealed growing divisions within the sector about the value of disaster relief. The DEC members had already met months earlier in 1973 to discuss Ethiopia and the Sahel, revealingly deciding not to request a broadcast appeal due to disagreements over the appropriate course of action. Christian Aid and War on Want wanted any appeal to be made in support of long-term development, rather than short-term relief. The British Red Cross and Save the Children opposed this position, on the basis that the situation 'demanded long-term attention by international agencies and governments rather than DEC member charities', and therefore they shouldstick to humanitarian assistance only. Oxfam supported long-term development in principle, but argued that in this case short-term relief was preferable. ${ }^{41}$

Th se discussions were a microcosm for broader trends crystallising within the aid community, as several (but not all) NGOs were engaging with confrontational theories of alternative development and exploring new avenues to publicise and tackle the root causes of global poverty, rather than solely ameliorating its visible eff cts. From the DEC this included CAFOD, Christian Aid, Oxfam and War on Want, who all took up the cause of long-term development in the global South over the course of the $960 \mathrm{~s}^{42}$ As these organisations matured in their epertise and programming, a critique of disaster reliefbegan to be articulated from within An early example was the publication of The Haslemere Declaration in 1968 by radical elements from Christian Aid and Oxfam, which likened charitable relief to 'tossing sixpence in a beggar's cap: moneygiven by those who have no intention of changing the system that produces beggars, and no understanding that they are part of it. ${ }^{43}$ War on Want's staff were particularly radical, commenting in 1973 that they were 'not a dsaster organisation' and no lorger wished to have an 'ambulance function' ${ }^{44}$

Disillusionment with disaster relief inspired a critique of the aesthetics of emergency fundraising. Th s critique denounced the ubiquitous images of suff ring children as unethical and counter-productive to new goals of raising the awareness and engagement of the British public in development issues and tackling global poverty. Th s thinking was apparent when Oxfam announced in 1973 (only a month before The Unknown Famine aired) that it would cease using such imagery altogether, and instead 'educate rather than incite pity'. The agency added that 'people have become blunted by disaster, so we now intend to concentrate on the constructive aspect of our work in advertisements'. War on Want commented at the same time that 'the starving child has really been fl gged to death, and we must now make the assumption that the energy we used to give to advertising forfunds must be spent on 
education of the public here..$^{45}$ The implication was clear - these organisations (or at least, certain sections of these organisations) were growing uncomfortable with the simplistic and misleading messages being promoted in theirfundraising appeals, which appeared to be contradictory to an emerging and more sophisticated public education and advocacy agenda.

The Unknown Famine therefore helped consolidate a colonial discourse of Africa and the 'third world' as a helpless region of disasters and suff ring, at the very historical moment that several prominent NGOs were seeking to challenge and undo it. Development-oriented NGOs could not turn away from the intense publicity whipped up by Dimbleby's documentary, despite their own misgivings. Oxfam and other agencies were thus compelled to endorse and perpetuate problematic messages whichtheyknew were misleading and over-simplistic, but appealed to a wider public. War on Want would later call for a way to ensure that fundraising communications would 'consider the long-term needs' and 'not react solely on the basis of ... Dimbleby's emotive programmes that tell only a fraction of the truth' ${ }^{46}$ While laudable, this critiquefailed to acknowledge how aid agencies were frequently not setting the terms on which they operated. As the sudden reversal of the DEC's earlier decision not to make an appeal for Ethiopia had shown, NGOs were regularly pulled and pushed between the sructural pressures of television coverage and public opinion

\section{The British government and disaster relief}

Thetremendousstrength of public feeling whipped up by The Unknown Famine not onlybrought pressure to bear on the leading humanitarian NGOs - it also made an important contribution to wider shifts in how the British government approached disaster relief. Britain had little involvement in either Ethiopia or the Sahel in the early 1970 s, with no signific nt historical or diplomatic ties to the region. TheBritish state had also been preoccupied during the late 1960s and early 1970s with major disasters in two of its former colonies (the Nigerian Civil War and the East Pakistan crisis). Both of these emergencies had signific nt political repercussions, and both had required signific nt diversions of funds from the official development aidbudget to pay foremergency reliefoperations. Doing so had stimulated heated debate within government over the correct response to major disasters, as the established policy was that disaster relief was of minimal political importance and any expenditure on it should be ightly restricted. ${ }^{47}$

The sudden exposure of the Ethiopian famine in 1973 caught the Conservative government by surprise. At this time the overseas aid budget was managed by the Overseas Development Adminstration (ODA), a department within the Foreign Office and the predecessor to today's Department for International Development (DFID). ${ }^{48}$ The sudden outcry which followed The Unknown Famine's broadcast had an immediate eff ct on official donors - as one ODA official commented, the documentary had 'stirred consciences in many countries and provoked an 
enormous response ... it even galvanised government machines.' ${ }^{49}$ The UN Food and Agriculture Organisation (FAO) launched an appeal for 500,000 tonnes of food aid and \$30 million for emergency relief in November 1973, which the British government contributed towards. At the same time, Britain (along with other donor governments) agreed to participate in an international programme of long-term development programmes throughout the Sahel. Britain also rolled out a major rural development programme inside Ethiopia. ${ }^{50}$ As Peter Woodward summarises, aft $\mathrm{r}$ The Unknown Famine the 'wheels of the relief juggernaut rolled a little faster.'51 The DEC member organisations also participated in these initiatives, benefi ing from official funding for tansporting equipment and supplies. ${ }^{52}$

Despite these effo ts, the film's shocking images of mass starvation raised difficult questions about how the faminehad occurred. The British government received widespread public and parliamentary criticism for its perceived lack of response, which was presented in the media as bureaucratic failure and indiff rence to human suff ring. Christian Aid's Deputy Director denounced the government for its 'lack of vigour, lack of imagination, and a lack of ground representation that goes beyond red tape or bureaucracy. ${ }^{53}$ TheMinister for Overseas Development (Richard Wood) recognised the 'considerable concern in the House of Commons, refl cting the concern in the country as a whole, that the British Government had repeatedly found itself reacting to crisis situations which might perhaps have been foreseen earlier. ${ }^{54}$ Theperceived inability of the British state apparatus to competently respond to third world disasters was publicly contrasted with the leading NGOs, who were depicted by many journalists as efficient, fle ible and nonbureaucratic. ${ }^{55}$

The public feeling unleashed by Dimbleby's film accelerated and culminated a trend that had been developing since the late 1960s. Decolonisation increased public awareness of hunger and poverty in the newly christened 'third world, while the simultaneous spread of television, along with concurrent advances in communications technology, brought a new immediacy and emotional impact to images of distant suff ring. News reports of overseas disasters helped stimulate humanitarian empathy amongst the viewing public, evoking an impulse to act immediately to 'save' newly post-colonial states. ${ }^{56}$ TheODA conceded in early 1974 that 'the quickaccess of news media to disasters and their presentation, especially by television, has created a Ministerial and public demand for a more immediate and fuller response. ${ }^{57}$ Wood acknowledged a 'change in public opinionover the last few years', with governments now 'expected to do more in distant countries than they had been.58 Ths acceptance that the government had 'to do more in distant countries' was an important turning point for the British state's involvement in humanitarian aid, marking a new signific nce for disaster relief in foreign policy. As one ODA official summarised, 'public and parliamentary opinion ... will not permit [the government] to do nothirg. 59

The immediate consequence of this shift was an internal review of the government's administrative machinery for emergency relief. A policy paper 
in early 1974 opened with the revealing statement that 'the problem of disaster relief in developing countries is one of which governments are becoming increasingly aware. ${ }^{6} 0$ Th s reform process took on a more radical character following the election of a Labour government in March 1974. The new administration altered the ODA to become a separate entity from the Foreign Office as the Ministry of Overseas Development (ODM), and Judith Hart replaced Wood as the Minister for Overseas Development. Hart had briefly served as Minister in 1970, and had been Labour's Shadow Minister in the years since. Hart and her advisors were highly critical of the previous administration's inefficient capacity for emergency relief, commenting that 'the only people who have emerged with credit from these disasters are the media' - referring specificaly to ITV and Jonathan Dimbleby. ${ }^{61}$ Hart's overhaul resulted in the creation of a Disaster Unit within the ODM in June 1974. A specialist body staff $d$ with experts, the Disaster Unit was a 'focal point' for responding to major disasters in the global South, which would regard emergency relief as a primary consideration rather than a distraction from long-term development. Other donor governments established similar bodies during the 1970s, institutionalising the distribution of humanitarian assistance and constructing the framework for a glbal relief network. ${ }^{62}$

The Disaster Unit also aspired for a closer relationship with the leading NGOs, to improve its capacity and eff ctiveness. Government officials stressed the need to 'make sure our effo ts were integrated with [voluntary organisations] ... we wish to plan and work in collaboration with these bodies at all stages, since their role will continue to be an essential one. ${ }^{63}$ Th s prioritisation of NGOs refl cted how aid agencies were being increasingly fêted for their perceived efficiency, expertise, lack of bureaucracy, and capacity to reach the poorest communities. Television was an integral aspect of this process, as it was through the mass media that NGOs publicised theirideals, acquired popular recognition, and thus stimulated theirown expansion. The emphasis placed by the ODM on co-ordination also represented a broader increase of state support for the voluntary sector in the 1970s, as a number of governmental departments looked for ways to liaise with NGOs and draw upon their distinctive capacities and methods. ${ }^{64}$

The Disaster Unit designated the DEC as its preferred vehicle for co-ordination, and in the following years the Unit frequently co-ordinated with the DEC members in responding to humanitarian crises of varying magnitudes. In practice, collaboration usually involved the Disaster Unit taking up a co-ordinating role, overseeing and directing NGO relief effo ts, for which it provided considerable fi ancial and logistical support. The 1970s thus witnessed the building up of connections and channels between humanitarian NGOs and the state, which would make possible the funndling of substantial official funds through the sector which has now become a routine norm. ${ }^{65}$ The Unknown Famine made an important contribution to this process, as it accelerated an overturning of governmental assumptions and helped permanently raise the prominence of humanitarian aid in pdicymaking. 


\section{Conclusion}

Th re have been many profoundchanges withinthe mass media and global humanitarianism since the 1973Ethiopianfamine Radicalimprovementsincommunications and information technology have constructed a global media ecology on a scale unimaginable in the 1970s Successive innovations suchas electronicnews-gathering, satellites, 24/ 7 news channels, the internet, mobile telephones and social media have been important spurs for globalisation, collapsing time and space and reducing the distance between people all over the globe ${ }^{6}{ }^{6}$ Live news reporting from warzones and disasters has now become routine, and it seems inconceivable that an African famine could remain 'unknown' today as Ethiopia's once did. Technological advances in the media have been analogous with a sustained growth of global humanitarianism, as evident in the phenomenal expansion and proliferation of international NGOs in recent decades ${ }^{67}$ British humanitarianism is now a vibrant and imposing fi ld of activity, with substantial funds fl wing into the sector from both the public and official donors. Th se trends are all evident in the recent history of the DEC, which underwent internal reform during the mid-1990s before being relaunched with an expanded membership and more professional governance mechanisms. The DEC has thrived in the years since (despite operating in a more commercially competitive broadcast environment), regularly raising massive funds from the public for disaster relief. Th s includes a remarkable record sum of $£ 392$ million for the Indian Ocean tsunami in $2004 .^{68}$

The representational practices of humanitarian NGOs have come under significant scrutiny since the 1970s. Critiques of emergency fundraising imagery (quite radical in 1973) permeated through the sector over the following decade, before exploding in the aftermath of the 1984-5Ethiopian famine. Thewidespread dissemination of images of starving Ethiopian children in the media, NGO appeals and the Band Aid fundraising events generated heated debate within the sector over their potentially harmful impact on public engagement and education ${ }^{69} \mathrm{Th}$ se debates resulted in the formulation of internal guidelines and shared Codes of Conduct amongst aid agencies, including the well-known 1992 Code of Conduct for the International Red Cross and Red Crescent Movement and NGOs in Disaster Relief. Virtually all mainstream NGOs are signatories to the 1992 code, which binds them to 'recognise disaster victims as dignifi $\mathrm{d}$ human beings, not hopeless objects' in theirinformation, publicity and advertising..$^{70}$ Since thelate 1980 s, many NGOs have also aspired to utilise 'positive' imagery in theircommunications, which depict their subjects as self-sufficient, dignifi d, active, and even heroic. Themotive behind this was that 'positive' representations could convey a more complex story of justice and equality, rather than simplistic paternalistic charity. ${ }^{71}$

However, despite these developments, many of the issues highlighted in this case study of the 1973 Ethiopian famine remain pertinent today. For all their growth and increased influ nce, NGOs are still dependent upon the mass media to 
set agendas and galvanise public responses. Furthermore, they do so withina highly crowded and competitive humanitarian sector, and a more fragmented commercial broadcast environment. Thus, despite a more nuanced awareness of the politics of representation, many NGOs are still driven by institutional imperatives to use problematic images and messages in their communications. Simon Cottle and David Nolan argue that humanitarian NGOs have now internalised a form of 'media logic', deliberately packaging their work in ways which conform to known media needs which tends to mean simplistic narratives, shocking images and regular use of celebrities. ${ }^{72}$ Some observers have spoken of a return to 'poverty porn' reminiscent of the 1970 s, due to the pressures of raising funds in a marketing-driven environment. ${ }^{73}$ The Unknown Famine may have marked the high point of these negative representations of Africa and the global South, but these images and stereotypes clearly still hold sway over the populdr imagination today.

Theeducation and advocacy campaigns of development NGOs were still in their infancy in 1973 , and there were genuinehopes within the aid community that paternalistic discourses of charity and disaster could be overturned. Four decades later, 'development education' appears to have largely failed as a project. Th s failure is borne out in successive opinion polls and surveys, which indicate that the British public's support for overseas aid is motivated by humanitarian and moral concerns only. Th re are low levels of popular engagement in issues relating to global poverty and inequality, of which the public is uninterested and knows littl ${ }^{74}$ Themedia, and especially television, has been critical to this process. Graphic images of suff ring children such as those aired in The Unknown Famine have consistently sparked an emotional response from viewers. Ths may be fundamental to the visual nature of television, and the news values which underpin its production - privileging the dramatic and shocking, while discouraging more complexverbal effo ts to explain why. ${ }^{75}$

Recent research fin ings suggest that the constant repetition of negative images and simplistic messages in NGO appeals is fostering growing cynicism, as many citizens feel such communications are cynically designed with the sole objective of making money Ths disconnection further limits the potential for these agencies to challenge the charitable frame through which so many people view and understand the wider world. ${ }^{76}$ Reversing these trends will be exceptionally difficult in the years to come, and may not be possible within the structural constraints of the commercialised aid industry. At the very least, there is a pressing need to revisit and strengthen agency Codes of Conduct on imagery and representation, and for all actors connected to the sphere of humanitarianism and international aid to acknowledge and evaluate the long-term impacts of their messages upon supporters and the general public. A case study of The Unknown Famine reminds us just how challenging this task can be. As one Oxfam official remarked in 1973 following the film's explosive impact, 'after two and a half years of our effo ts to publicise the causes of underdevelopment, 15 minutes of publicising the eff cts through the film seemed to do it.' 


\section{Notes}

1 SeeE. Balabanova, The Media and Human Rights: The Cosmopolitan Promise (London: Routledge, 2014); S. Cottle and G. Cooper, 'Introduction: Humanitarianism, Communications, and Change', in S. Cottle and G. Cooper (eds), Humanitarianism, Communications and Change (New York: Peter Lang, 2015), pp. 1-18; S. Cottle and C. M. Hughes, 'The United Nations' "Responsibility to Protect" and the Worlds Press: Establishing a New Humanitarian Norm?, in J. Hoffman and V. Hawkins (eds), Communication and Peace: Mapping an Emerging Field (Abingdon: Routledge, 2015), pp 76-91.

2 The historiography of humanitarianism in particular has been flou ishing in recent years. Michael Barnett's historical overview remains a seminal publication: Empire of Humanity: A History of Humanitarianism (Ithaca: Cornell University Press, 2011). See also Kevin O'Sullivan et al.'s recent journal introduction for an overview of major themes in the literature: K. O'Sullivan, M. Hilton and J. Fiori, 'Humanitarianisms in Context: Histories of Non-State Actors, from the Iocal to the Glbal', European Review of History, 23:1-2 (2016), pp. 1-15.

3 The landscape of British television in 1973 was radically diff rent to the competitive and fragmented environment of the twenty-fi st century. Th re were only two television broadcasters - the publicly funded BBC, and the commercial Independent Television network (ITV). Th se broadcast three channels in total - BBC1, BBC 2 and ITV. For more on the historical development of British television, see J. Curran and J. Seaton, Power Without Responsibility: Press, Broadcasting and the Internet in Britain (Abingdon: Routledge, 7th edn, 2009), pp. 101-232.

4 P. Harrison and R. Palmer, News Out of Africa: Biafra to Band Aid (London: Hilary Shipman, 1986), p. 6.

5 S. Franks, Reporting Disasters: Famine, Aid, Politics and the Media (London: C. Hurst and Co., 2013); A. Jones, 'Band Aid Revisited: Humanitarianism, Consumption, and Philanthropy in the 1980', Contemporary British History, 31:2 (2017), pp. 189-209.

6 P. Webb, Y. Yohannes and J. Von Braun, Famine in Ethiopia: Policy Implications of Coping Failure at National and Household Levels (Washington, DC: IFPI, 1992), p. 20.

7 J. R. Butterly and J. Shepherd, Hunger: The Biology and Politics of Starvation (Lebanon, NH: University Press of New England, 2010), pp. 153-6.

8 K. Doheny, No Hands But Yours: Memoirs of a Missionary (Dublin: Veritas, 997), pp 98-106.

9 Oxfam Archive, Bodleian Library, University of Oxford (hereafter OA), MS.Oxfam COM/2/ 6/ 8, Oxfam Information Office, 'TheFaminein Ethiopia: General Description', February 1974.

$10 \mathrm{OA}$, MS.Oxfam COM/2/6/8, T. Hall, 'Journal of visit to drought/ famine areas last week of August', September 1973.

11 Quoted in Harrison and Palmer, News Out of Africa, pp. 48-9.

12 P. Holland, The Angry Buzz: This Week and Current Affairs Television (London: I. B. Tauris, 2006), p. 76.

13 This Week, The Geat Drought, fi st transmitted 28 June 1973

14 Interview with Jonathan Dimbeby, conducted by the author (Andrew Jones), 12 June 2015.

15 Interview with Jonathan Dimbleby, conducted by the author (Andrew Jones), 12 June 2015.

16 The full story of how The Unknown Famine was filmed and smuggled out of Ethiopia is recounted at length in Harrison and Palmer, News Out of Africa, pp. 40-66.

17 Holland, The Angry Buzz, p. 90.

18 Independent Television Authoirty (ITA) Archive, University of Boumemouth Library (hereafter ITAA), Th s Week scripts collection, 'The Unknown Famine (original script)', October 1973 
19 ITAA, box 3996264, file 5002/5, vol. 1, K.W. Blyth, 'Special Disaster Appeal Procedures: Memorandum by the BBA Appeals Secretary', 1 April 1974.

20 OA, MS.Oxfam COM/2/6/ 8: Oxfam Information Office, 'The Famine in Ethiopia: General Description', February 1974.

21 'Off rs of hdp for thiopia', Oxfam News, 92 (November 1973),p. 1.

22 A. Jones, 'The Disasters Emergency Committee (DEC) and the Humanitarian Industry in Britain, 1963-85, Twentieth Century British History, 26:4 (2015), pp 573-601.

23 BBC Written Archives Centre, Caversham (hereafter BBC WAC), B420-4-1, D.B. Mann, 'Disasters Emergency Committee', 27 November 1973.

24 Disasters Emergency Committee, 'Ethiopian and African Drought Appeal', Guardian (31 October 1973),p. 9.

25 See: http:// awards.bafta.org/award/ 1974/television/richard-dimbleby-award. Accessed 12 September 2016.

26 P. Gill, Famine and Foreigners: Ethiopia Since Live Aid (Oxford: Oxford University Press, $2010)$, p. 34 .

27 Jones, 'The Dsasters Emergency Committee'.

28 ITAA, box 3996264, file 5002/5, vol. 1, K.W. Blyth, 'Special Disaster Appeal Procedures: Memorandum by the BBA Appeals Secretary', 1 April 1974.

29 OA, MS.Oxfam PRG/2/3/8/ 16, 'El Salvador Earthquale evaluation meeting', 20 January 1987.

30 Gill, Famine and Foreigners, p. 29.

31 Quoted in Harrison and Palmer, News Out of Africa, pp. 55-6.

32 Interview with Jonathan Dimbleby, conducted by the author, $\mathrm{Z}$ June 2015.

33 Disasters Emergency Committee, 'Ethiopian and African Drought Appeal'.

34 Christian Aid Archives, SOAS Library, London (hereafter CAA), box CA2/D/20, file CA2/ D/20/2, P. Jackson, 'Letter to DEC Agencies', 22 March 1974.

35 Jones, 'The Dsasters Emergency Committee'.

36 S. Cohen, States of Denial: Knowing about Atrocities and Suffering (Cambridge: Polity, 2001); S. Sontag, Regarding the Pain of Others (London: Penguin, 2003); K. Manzo, 'Imaging Humanitarianism: NGO Identity and the Iconography of Childhood, Antipode, 40:4 (2008), pp. 632-57; L. Rideout, 'Representations of the “Thid World” in NGO Advertising: Practicalities, Colonial Discourse and Western Understandings of Development', Journal of African Media Studies, 3:1(2011),pp.25-41;N.Dogra, Representations of Global Poverty: Aid, Development and International NGOs (London: I. B. Tauris, 2012); S. Orgad, Media Representation and the Global Imagination (Cambridge, MA: Polity, 2012).

37 P. Holland, 'Crybabies and Damaged Children', What Is A Child? Popular Images of Childhood (London: Virago, 1992), pp. 148-73;J. N. Pieterse, White on Black: Images of Africa and Blacks in Western Popular Culture (New Haven: Yale University Press, 1992); S. Koven, Slumming: Sexual and Social Politics in Victorian London (Princeton: Princeton University Press, 2004); Manzo, 'Imaging Humanitarianism'; E. Baughan, "Every Citizen of Empire Implored to Save the Children!" Empire, Internationalism and the Save the Children Fund in Inter-war Britain, Historical Research, 86:231 (2013), pp 116-37.

38 M. Black, A Cause for Our Times: Oxfam, the First Fifty Years (Oxford: Oxfam, 1992), pp. $79-80$.

39 T. Vaux, The Selfish Altruist: Relief Work in Famine and War (London: Earthscan, 2001),p. 15.

40 Cohen, States of Denial, p. 178.

41 CAA, box CA2/D/ 11, file CA2/D/11/6, Disasters Emergency Committee, 'Notes of the 82nd meeting', 10 July 1973. 
42 Black, A Cause for Our Times, p. 70; A. Bocking-Welch, 'Imperial Legacies and Internationalist Discourses: British Involvement in the United Nations Freedom from Hunger Campaign, 1960-70', Journal of Imperial and Commonwealth History, 40:5 (2012), pp. 879-96.

43 Haslemere Declaration Group, The Haslemere Declaration: A Radical Anaysis of the Relationships between the Rich World and the Poor World (London: Haslemere Declaration Group and Thi d World First, 1968).

44 WOWA, box 222, file 02037, War on Want, 'Minutes of the Meeting of Directors (Council)', 15 January 1973

45 L. Mackie, 'Oxfam Changing Child Plea Image', Guardian (6 October 1973),p. 4.

46 WOWA, box 222, file 02039, P. Burns, 'Address to 1974 Annual General Meeting', 19 October 1974.

47 The National Archives of the UK, Kew (hereafter TNA), DO 35/9162, 'H.M. Government assistance after natural disasters abroad', 18 July 1955; TNA, OD 20/500, R. Wood, 'letter to A. Barber', 15 June 1971

48 For a historical overview of the evolution of DFID, see B. Ireton, Britain's International Development Policies: A History of DFID and Overseas Aid (Basingstoke: Palgrave Macmillan, 2013).

49 TNA, FCO 59/1237, D.M. Kerr, 'International Disaster Relief', 2 May 1974.

50 'Europe's $£ 110 \mathrm{M}$ for Food Aid', Guardian (26 January 1974), p. 2.

51 P. Woodward, The Horn of Africa: Politics and International Relations (London: I. B. Tauris, 2003), pp 174-6.

52 TNA, OD 30/449, 'Paper on dought relief - Sahelian zone and Ethiopia', 21 December 1973.

53 P. Niesewand, 'Britain Plans Food Airlift o the Sahel', Guardian (9 April 1974), p. 2.

54 TNA, OD 15/119, Overseas Development Adminstration, 'Note of a Meeting: Disaster Relief,' 8 November 1973

55 TNA, OD 15/119, Overseas Development Adminstration, 'Note of a Meeting: Disaster Relief, 8 November 1973

56 Vaux, The Selfish Altruist, p. 15; M. C. Morgan, 'The Seventies and the Rebirth of Human Rights', in N. Ferguson et al. (eds), The Shock of the Global: The 1970s in Perspective (Cambridge, MA: Belknap, 2010), pp. 237-50.

57 TNA, FCO 59/1237, E.C. Burr, 'Disaster Relief', February 1974.

58 TNA, OD 15/119, Overseas Development Adminstration, 'Note of a Meeting: Disaster Relief, 8 November 1973.

59 TNA, OD 15/119, W. Morris, 'Action in famine situations: early lessons from the Ethiopian experience', $\mathrm{L}$ December 1973.

60 TNA, FCO 59/1237, Overseas Development Adminstration, 'British Disaster Relief Policy', 7 February 1974.

61 TNA, FCO 59/1237, D.M. Kerr, 'International Disaster Relief', 2 May 1974.

62 R.C. Kent, 'Refl cting upona Decade ofDisasters: TheEvolving Response of the International Community', International Affairs, 59:4 (1983), pp. 693-711;E. Davey, J. Borton and M. Foley, 'A History of the Humanitarian System: Western Origins and Foundations', ODI HPG Working Paper (London: Overseas Development Institute, 2013).

63 TNA, OD 5/119, 'Disaster Unit: material for pess conference', June 1974.

64 M. Hilton, J. McKay, N. Crowson and J. Mouhout, The Politics of Expertise: How NGOs Shaped Modern Britain (Oxford: Oxford University Press, 2013), p 193.

65 D. Hulme and M. Edwards (eds), NGOs, States and Donors: Too Close for Comfort? (Basingstoke: Palgrave Macmillan, 1997); A. Bebbington, 'Donor-NGO Relations and 
Representations of Livelihood in Nongovernmental Aid Chains', World Development, 33:6 (2005), pp. 937-50; N. Banks, D. Hulme and M. Edwards, 'NGOs, States, and Donors Revisited: Still Too Close for Comfort?, World Development, 66 (2015), pp 707-18.

66 Cottle nd Cooper, 'Introduction'.

67 M. Barnett and T. G. Weiss (eds), Humanitarianism in Question: Politics, Power, Ethics (Ithaca: Cornell University Press, 2008).

68 Jones, 'The Dsasters Emergency Committee'.

69 Franks, Reporting Disasters; P. CoulterandG. Cooper, 'NGOs, Media andPublic Understanding 25Years On', in S. Cottle and G. Cooper (eds), Humanitarianism, Communications and Change (New York: Peter Lang, 2015), pp 79-89.

70 See: www.ifrc.org/en/publications-and-reports/code-of-conduct/. Accessed 12 September 2016.

71 Dogra, Representations of Global Poverty, pp. 6-7; S. Orgad, 'Underline, Celebrate, Mitigate, Ease: Humanitarian NGOs' Strategies of Communicating Diff rence', inS. Cottleand G. Cooper (eds), Humanitarianism, Communications and Change (New York: Peter Lang, 2015), p 132.

72 S. CottleandD. Nolan, 'Global Humanitarianismand the Changing Aid-Media Field: Everyone Was Dying for Footage', Journalism Studies, 8:6 (2007), pp. 862-78.

73 J. Hilary, 'The Unwelcome Return of Development Pornography', New Internationalist (December 2014).

74 Voluntary Service Overseas, The Live Aid Legacy: The Developing World through British Eyes - A Research Report (London: VSO, 2001); I. McDonnell, 'United Kingdom', in I. McDonnell et al. (eds), Public Opinion and the Fight against Poverty (Paris: OECD, 2003), pp. 217-24; A. Darnton and M. Kirk, Finding Frames: New Ways to Engage the UK Public in Global Poverty (London: Bond, 2011); D. Hudson and J. vanHeerde-Hudson, A Multilevel Analysis of Public Support for Development across the EU 1995-2012 (London: University College London,2013).

75 J. Benthall, Disasters, Relief and the Media (London: I. B. Tauris, 1993); S. D. Moeller, Compassion Fatigue: How the Media Sell Disease, Famine, War and Death (New York: Routledge, 1999); CARMA International, The CARMA Report on Western Media Coverage of Humanitarian Disasters (Washington, DC: CARMA, 2006); Franks, Reporting Disasters.

76 I. B. Seu, 'Learning from the Public: UK Audiences' Responses to Humanitarian Communications', in S. Cottle and G. Cooper (eds), Humanitarianism, Communications and Change (New York: Peter Lang, 2015), pp 167-82.

77 ITAA, This Week scripts collection, The Unknown Famine: A Report on Famine in Ethiopia (London: Thames Television, 1974).

\section{References}

Balabanova, E., The Media and Human Rights: The Cosmopolitan Promise (London: Routledge, 2014).

Banks, N., D. Hulme and M. Edwards, 'NGOs, States, and Donors Revisited: Still Too Close for Comfort?', World Development, 66 (2015), pp 707-18.

Barnett, M., Empire of Humanity: A History of Humanitarianism (Ithaca: Cornell University Press, 2011).

Barnett, M. and T. G. Weiss (eds), Humanitarianism in Question: Politics, Power, Ethics (Ithaca: Cornell University Press, 2008).

Baughan, E., " Every Citizen of Empire Implored to Save the Children!" Empire, Internationalism and the Save the Children Fundin Inter-war Britain', Historical Research, 86:231(2013), pp. 116-37. 
Bebbington, A., 'Donor-NGO Relations and Representations of Livelihood in Nongovernmental Aid Chains', World Development, 33:6 (2005), pp 937-50.

Benthall, J., Disasters, Relief and the Media (London: I. B. Tauris, 1993).

Black, M., A Cause for Our Times: Oxfam, the First Fifty Years (Oxford: Oxfam, 1992).

Bocking-Welch, A., 'Imperial Legacies and Internationalist Discourses: British Involvement in the United Nations Freedom from Hunger Campaign, 1960-70', Journal of Imperial and Commonwealth History, 40:5 (2012), pp. 879-96.

Butterly, J. R. and J. Shepherd, Hunger: The Biology and Politics of Starvation (Lebanon, NH: University Press of New England, 2010).

CARMA International, The CARMA Report on Western Media Coverage of Humanitarian Disasters (Washington, DC: CARMA, 2006).

Cohen, S., States of Denial: Knowing about Atrocities and Suffering (Cambridge: Polity, 2001).

Cottl , S. and G. Cooper, 'Introduction: Humanitarianism, Communications, and Change', in S. Cottleand G. Cooper (eds), Humanitarianism, Communications and Change (New York: Peter Lang, 2015), pp 1-18.

Cottl , S. and C. M. Hughes, 'The United Nations' "Responsibility to Protect" and the Worlds Press: Establishing a New Humanitarian Norm?', in J. Hoffman and V. Hawkins (eds), Communication and Peace: Mapping an Emerging Field (Abingdon: Routledge, 2015),pp. 76-91.

Cottl , S. and D. Nolan, 'Global Humanitarianism and the Changing Aid-Media Field: Everyone Was Dying for Footage', Journalism Studies, 8:6 (2007), pp. 862-78.

Coulter, P. and G. Cooper, 'NGOs, Media and Public Understanding 25 Years On', in S. Cottle and G. Cooper (eds), Humanitarianism, Communications and Change (New York: Peter Lang, 2015), pp 79-89.

Curran, J. and J. Seaton, Power Without Responsibility: Press, Broadcasting and the Internet in Britain (Abingdon: Routledge, 7th edn, 2009).

Darnton, A. and M. Kirk, Finding Frames: New Ways to Engage the UK Public in Global Poverty (London: Bond, 2011).

Davey, E., J. Borton and M. Foley, 'A History of the Humanitarian System: Western Origins and Foundations', ODI HPG Working Paper (London: Overseas Development Institute, 2013).

Disasters Emergency Committee, 'Ethiopian and African Drought Appeal', Guardian (31October 1973),p. 9.

Dogra, N., Representations of Global Poverty: Aid, Development and International NGOs (London: I. B. Tauris, 2012).

Doheny, K., No Hands But Yours: Memoirs of a Missionary (Dublin: Veritas, 1997).

Franks, S., Reporting Disasters: Famine, Aid, Politics and the Media (London: C. Hurst and Co., 2013). Gill, P., Famine and Foreigners: Ethiopia Since Live Aid (Oxford: Oxford University Press, 2010).

Harrison, P. and R. Palmer, News Out of Africa: Biafra to Band Aid (London: Hilary Shipman, 1986).

Haslemere Declaration Group, The Haslemere Declaration: A Radical Anaysis of the Relationships between the Rich World and the Poor World (London: Haslemere Declaration Group and Thi d World First, 1968).

Hilary, J., 'The Unwelcome Return of Development Pornography', New Internationalist (December 2014).

Hilton, M., J. McKay, N. Crowson and J. Mouhout, The Politics of Expertise: How NGOs Shaped Modern Britain (Oxford: Oxford University Press, 2013).

Holland, P., 'Crybabies and Damaged Children', What Is A Child? Popular Images of Childhood (London: Virago, 1992), pp 148-73.

Holland, P., The Angry Buzz: This Week and Current Affairs Television (London: I. B. Tauris, 2006). 
Hudson, D. and J. vanHeerde-Hudson, A Multilevel Analysis of Public Support for Development across the EU 1995-2012 (London: University College London,2013).

Hulme, D. and M. Edwards (eds), NGOs, States and Donors: Too Close for Comfort? (Basingstoke: Palgrave Macmillan, 1997).

Ireton, B., Britain's International Development Policies: A History of DFID and Overseas Aid (Basingstoke: Palgrave Macmillan, 2013).

Jones, A., 'TheDisasters Emergency Committee (DEC) and the Humanitarian Industry in Britain, 1963-85', Twentieth Century British History, 26:4 (2015), pp 573-601.

Jones, A., 'Band Aid Revisited: Humanitarianism, Consumption, and Philanthropy in the 1980s', Contemporary British History, 31:2 (2017), pp. 189-209.

Kent, R. C., 'Refl cting upon a Decade of Disasters: TheEvolving Response of the International Community', International Affairs, 59:4 (983), pp 693-711.

Koven, S., Slumming: Sexual and Social Politics in Victorian London (Princeton: Princeton University Press, 2004).

Mackie, L., 'Oxfam Changing Child Plea Image', Guardian (6 October 1973),p. 4.

Manzo, K., 'Imaging Humanitarianism: NGO Identity and the Iconography of Childhood, Antipode, 40:4 (2008), pp. 632-57.

McDonnell, I., 'United Kingdom', in I. McDonnell, H. Lecomte and L. Wegimont (eds), Public Opinion and the Fight against Poverty (Paris: OECD, 2003), pp 217-24.

Moeller, S. D., Compassion Fatigue: How the Media Sell Disease, Famine, War and Death (New York: Routledge, 1999).

Morgan, M. C., 'TheSeventies and the Rebirth of Human Rights', in N. Ferguson, E. Manela, C. S. Maier and D. J. Sargent (eds), The Shock of the Global: The 1970s in Perspective (Cambridge, MA: Belknap, 2010), pp. 237-50.

Niesewand, P., 'Britain Plans Food Airlift o the Sahel', Guardian (9 April 1974), p. 2.

O'Sullivan, K., M. Hilton and J. Fiori, 'Humanitarianisms in Context: Histories of Non-State Actors, from the Local to the Gldbal', European Review of History, 23:1-2 (2016), pp. 1-15.

Orgad, S., Media Representation and the Global Imagination (Cambridge, MA: Polity, 2012).

Orgad, S., 'Underline, Celebrate, Mitigate, Ease: Humanitarian NGOs' Strategies of Communicating Diff rence', in S. Cottle and G. Cooper (eds), Humanitarianism, Communications and Change (New York: Peter Lang, 2015), pp 117-32.

Pieterse, J. N., White on Black: Images of Africa and Blacks in Western Popular Culture (New Haven: Yale University Press, 1992).

Rideout, L., 'Representations of the "Thi d World" in NGO Advertising: Practicalities, Colonial Discourse and Western Understandings of Development', Journal of African Media Studies, 3:1 (D)11), pp 25-41

Seu, I. B., 'Learning from the Public: UK Audiences' Responses to Humanitarian Communications', in S. Cottle and G. Cooper (eds), Humanitarianism, Communications and Change (New York: Peter Lang, 2015), pp 167-82.

Sontag, S., Regarding the Pain of Others (London: Penguin,2003).

Vaux, T., The Selfish Altruist: Relief Work in Famine and War (London: Earthscan, 2001).

Voluntary Service Overseas, The Live Aid Legacy: The Developing World through British Eyes A Research Report (London: VSO, 2001).

Webb, P., Y. Yohannes and J. Von Braun, Famine in Ethiopia: Policy Implications of Coping Failure at National and Household Levels (Washington, DC: IFPI, 1992).

Woodward, P., The Horn of Africa: Politics and International Relations (London: I. B. Tauris, 2003). 


\section{Part III}

Reporting refuge and risk 



\title{
European borderscapes: The management of migration between care and control
}

\author{
Pierluigi Musarò
}

Tens of thousands of migrants and refugees stranded in camps in Greece and in Calais, shipwrecks and deaths in the Mediterranean, fences and walls across the Balkans, hotspots along the European Union (EU) southern borders, increasing controls within the Schengen space, military-humanitarian naval operations, the EU-Turkey migrant deal, NGOs and activists denounang the ongoing 'war on migrants' is too often framed as a humanitarian emergency: these are some of the images we usually associate with the so-called 'migration crisis.' Nevertheless, this 'crisis' is neither new nor exceptional, especially when viewed through a historical lens. Th s discourse of an allegedly uncontrolled invasion of Europe dates back to the 1990s when the alarming image was fi st used particularly in the Spanish media, followed by the Italian media. Soon the packed refugee boat on the open sea became the image that symbolised migration to Europe. It also became the central figurative element in the debate on European refugee and migration policy and was used by all sides to legitimise their espective demands and ideas. ${ }^{2}$

Over the last two decades, while the EU has more or less eliminated internal borders between member states in order to create a unifi $d$ integrated European market, it has also sought to secure the EU's commonexternal border in response to fears that a continuum of 'unirvited' - unauthorised immgrants, known and suspected crimimals and terrorists - will 'deluge' Europe. ${ }^{3}$ Th se fears were amplifi $\mathrm{d}$ and fomented in the wake of $9 / 11$ and the subsequent terrorist attacks in Madrid, London, Paris, and the following major attacks in 2016 that have taken place in Brussels and Nice. ${ }^{4}$ Moreover, propaganda declaring war on Rome was released by the established presence of IslamicState affiliates on Libyas coast, and the potential threats that terrorists could take control of migration networks were disseminated. ${ }^{5}$ Th se events have increased the perception of the Mediterranean as Europe's vulnerable underbelly.

Articulating freedom of movement within the Schengen space with a variable geometry of control of the external frontiers, the 1990s are marked as the period 
when the EU began tightening and militarising its borders. ${ }^{6}$ The EU justifi $\mathrm{d}$ its massive investments in border controls through the narratives of national security combating human smuggling and potential terrorists. ${ }^{7}$ As well as a narrative of humanitarian action - rescuing lives and protecting asylum seekers' human rights. ${ }^{8}$ As such, it becomes clear that the current focus on both the securitisation and the humanitarian sides of the phenomenon supports a more complex logic of risk and benevolence, of threat and vulnerability, allowing for a military-humanitarian response. ${ }^{9}$

Therepresentation strategies and discursive practices enacted by a wide range of state and non-state actors present the Mediterranean Sea as the setting of a perpetual emergency. European and national political agencies, military authorities, humanitarian organisations, and activists, have been representing migrants crossing borders as a signific nt problem to be managed in terms of a wider social, cultural and political 'crisis'. Far outstripping any real crisis is the public anxiety about migration and asylum seeking in Europe, whichin part has grown due to the media coverage of the phenomenon as well as the rhetoric of politicians, who describe Europe as being besieged by people fl eing conflict or seking a better life. ${ }^{10}$

The whole complex of these actors, their discourses, as well as theirtechnologies of surveillance and control - whichare at the same timeconfronted by diverse actors in theirattemptsto cross borders or to facilitate their transgression - is what several critical migration and border scholars describe with the notion of 'border regime. ${ }^{11}$ While constructing an Elysiumlike sanctuary protected by perimeter fortific tions and remote control border strategies, most of the EU and national actors commonlydepict a border regime that is turning the Mediterranean into a mass grave in depoliticising terms as a 'humanitarian' crisis with its root causes always att ibuted to troubles 'elsewhere' - Africa, the Middle East and Asia - usually in desperate and chaotic places beyond the borlers of Europe. ${ }^{12}$

TheEU has been devising a securitised, depoliticising and technocratic approach towards the Mediterranean, which arises from the EU's construction of the region based on geopolitical considerations and threat perceptions. ${ }^{13}$ As Cebeci and Schumacher argue, securitisation refers to the state of exception where everything else is subordinated to the logic of security, commonlyexpressed through the rhetoric of the threat of terrorism, illegal immgration, energy disruption, the rise of extremism, economicinstability or the proliferation of weapons of mass destruction. It prioritises security over concerns with regard to democracy, human rights and socio-economic neds of the local.

At the same time, removing the securitised issues from public debate and referring to the crisis in abstract technicalterms, the EU's securitised approach to the Mediterranean is depoliticising because it means imposing the EU's measures on target societies without letting them 'politically' decide on their own lives and/or futures. Rather, it makes them agree on a set of standards, benchmarks and measures imposed on them by the EU and/or its member states. 
As Kurki states, depoliticisation mainly refers to a technocratic approach which is based on 'a discursive set of ideals for governance, which emphasise the virtues of depoliticisation, harmonisation, rationalisationand objectific tion of policy-making and evaluation, and which promotes the role of technicalexperts in policy-making over substantively "political" or "democratic" pulic actors. ${ }^{14}$

Ironically, at the same time, theEU authorities point to the high death toll, particularly in and around the Mediterranean, as part of their rationale for more restrictive border enforcement measures. As Shields claims, analysing the human cost of the EU's border regime, 'the claim is that the surveillances and border control system will save lives by providing "pre-frontier" infomation that will permitborder patrol agents to intercept migrants' vessels soon after departure and before they undergo hazardous journeys. ${ }^{15}$ Nevertheless, as Weber and Pickering persuasively argue, much of the death toll associated with displacement eff cts shouldbe understood as a form of 'structural violence. ${ }^{16}$ That is, rather than these deaths being directly att ibutable to an individualculprit, responsibility lies in good measure with the various public and private institutions, organisations, networks of actors and structures that forge and implement the EU's border control policy. In other words, the problem is that, adopting the alarming and compassionate frame in currently covering the 'crisis' and its management, the same state actors (Frontex, NATO and other EU members) and non-state actors (MOAS, MSF, Sea Watch and other humanitarian ships patrolling off the coast of Libya) use media (websites, social networks, newsletters, press releases) in a way that feed the depoliticising rhetoric of 'crisis. ${ }^{17}$ Thus, this depoliticised politics based on compassionate care and technocratic control contributes to construct the Mediterranean as a 'migration crisis space' in which it is totally misperceived the same role and culpability in what has becomea routine production of sriousharm.

As Calhoun claims, crisis demands an immediate response often thought to be outside of politics. ${ }^{18}$ It asks that the situation categorised as a crisis be managed in some way. However, this crisis management is focused onlyon restoring the status quo, not on changing it. Meanwhile, questions regarding what this status quo looks like remain unaddressed. ${ }^{19}$ Thus, policymakers and commoncitizens do not realise that this crisis is also a crucial opportunity to reform an unsustainable system, changing it for the better. What are current communication strategies on 'migrants/ refugees crisis' of the several European actors aiming at? What role do the media play in shaping this 'crisis'? And how does this aff ct solidarity with refugees?

Taking as a starting point Michel Foucault's work on biopolitics, Giorgio Agamben's work on sovereign power and bare life, and Achille Mbembe's work on necropolitics, this chapter focuses on the ambiguities and contradictions that bedevil discourses and practices around control and care of human mobility in the Mediterranean. ${ }^{20}$ Contemporary scholarship provides important insights into the ways that migrant deaths result from bordering practices that govern through death. ${ }^{21}$ Ths chapter aims to shed light on the role of 'crisis' narratives and the 
hyper-visibility of the 'military-humanitarian spectacle of the border' in obscuring (by making it invisible) the political stakes surrounding European borders. ${ }^{22}$

Diff rent aspects of the European border regime in the Mediterranean may appear paradoxical, incoherent and mutually contradictory: the role of humanitarian narratives and the human rights discourse in Frontex's operational activities; the language of combating human smuggling commonlyused by the Italian navy while simultaneously rescuing lives; Barcelona's digital billboard that counts the number of people who have died in the Mediterranean in 2016; and the media campaigns aimed at dissuading African would-be migrants from making the unsafe joumey to Europe launched by Hungary, Denmark and Italy. Th s chapter explores the double-sided nature of the military-humanitarian governance of migration, and suggests that these aspects are part of the intricate dichotomies of care and control that mark contemporary migration regimes.

\section{Frontex and the humanitarian borderlands}

Europe is at War against an Imaginary Enemy is Frontexit's campaign slogan. ${ }^{23}$ Supported by a platform of human rights organisations, the campaign started in March 2013 to unveil the increasingly securitarian approach by EU member states. The campaign was launched through a short video that taunts Frontex's quasimilitary role in policing the borders, while denounang how the EU has invested millions of euros in deploying disproportionate measures to fight an enemy who is not a real enemy: the migrant.

Ths campaign is a good example to start a discussion of the politics of the Mediterranean 'migration crisis'. It focuses on the European Agency for the Management of Operational Cooperation at the External Borders of the EU Frontex. ${ }^{24} \mathrm{Th} s$ agency has received a fairamount of criticism for its joint operations in the Mediterranean, and has been the most visible representative of the militarisation of European borders and of the so-called outsourcing of European asylum rights to third countries. ${ }^{25}$ Frontex was created in 2004 as a 'compensatory measure' to Schengen. ${ }^{26}$ Its overall mission is to promote and coordinate the management of EU's external borders, and it does so through common risk analysis, training of border guards, and most visibly, through expansive joint return, sea and land border operations. It has approximately 300 employees stationed in its headquarters in Warsaw, and a much larger pool of personnel and equipment at its disposal from member states for potential operations. ${ }^{27}$ It receives funding mainlyfrom the European Commission, in addition to funding from some member states, such as the Schengen countries. The agency's budget has grown from EUR 6.2 min 2005 to EUR $119.2 \mathrm{~min} 2013$, exceeding that of Europol. ${ }^{28}$ How does Frontex's public communication explain and legitimise its actions and the increasing investment in border control to the citizens of Europe and to the national politicians of the EU member states? 
According to Horsti, through media, Frontex discursively assures its public that there are security concerns and border problems, which the agency needs to 'combat. ${ }^{29}$ For example, it reinforces official security initiatives through its language and practice of risk analysis. One defini ion of risk used by the agency is: 'Most risks associated with document fraud were assessed as high. Indeed, document fraudsters not only undermine border security but also the internal security of the EU. ${ }^{30}$ Implicit in this defini ion is a view of the border as 'vulnerable', while the people crossing it are construed as a threat. On the other hand, in recent years, Frontex is also embracing the discursive strategy of humanitarianism, based on saving migrant lives. After human rights activists and NGOs began complaining about its mission to protect the 'Fortress Europe' withoutrespecting minimum human rights standards, the humanitarian discursive strategy has become a direct response to that. For example, the prevention of migrants from reaching their 'illegitimate' destination is described as a humanitarian action, 'saving lives'. In these joint operations with member states, Frontex prevented migrants from continuing theirjoumey and forced them to return. At the same time, since the security discourse focuses on the traffi ing and smuggling of humans, migrants are typically described as 'victims' of these criminals, and therefore those 'detected' in surveillance operations are 'protected'. 31

Shouldwe consider this humanitarian discourse simply a smokescreen fora repressive practice, as a critical observer might be tempted to conclude?Investigating this conflicting and ambiguous position of human rights and humanitarian ideals in the policing of European borders, Aas and Gundhs analyse the complex role of humanitarian thinking and the human rights discourse in Frontex operational activities. ${ }^{32}$ Based on interviews with Frontex officials and border guard officers, and on the analysis of relevant policy documents and official reports, they reveal that the emotive narratives of compassion and humanitarian assistance feature prominently in the agency's internal discourse, its training standards and in its self-presentation. Th s type of paradoxical policing - termed by the authors 'humanitarian borderlands' - is 'often conducted simultaneouslywith, against and through humanity. Themission is framed andlegitimized through the language of humanitarianism and human rights, officers are partly required to perform theirtasks as humanitarian agents, at the same time as they find themselves complicit and practically involved in deeply inhumane conditions.' ${ }^{33}$

\section{The Italian navy and the compassionate repression}

A similar integration of humanitarian and security responses within a common 'emergency frame' can be explored through the representation strategies and discursive practices enacted by the Italian navy since the launch of the operation Mare Nostrum. ${ }^{34}$ The military-humanitarian operation - targeted at both rescuing migrants and arresting smugglers, while stopping the illegal entry of unauthorised 
migrants - was established by the Italian government after two big shipwrecks off Lampedusa on 3 and 11 October 2013, which resulted in the deaths of over 600 migrants. It was launched on the wave of the compassionate reaction of citizens watching hundreds of coffins on their television screens. Although Mare Nostrum signifi $\mathrm{d}$ a strengthening of two other permanent missions co-ordinated and fi anced by Frontexand Italyand operating in the Mediterranean during this period, it constituted a transformative moment that contributed to reshape the relationship between the military and the humanitarian aspect of the naval operations. ${ }^{35}$ As we can read on the Italian navy's website, Mare Nostrum was established 'to tackle the dramatic increase of migratory fl ws during the second half of the year and consequent tragic shipwrecks off the island of Lampedusa'. At the same time, 'the naval and air units deployed by Mare Nostrum were necessary to improve maritime security, patrol sea lanes and combat illegal activities, especially human traffi ing. ${ }^{36}$ As such, the operation was led by military personnel and means, with the participation of voluntary healthcare operators. The Italian navy, on the one hand, deployed amphibious vessels, frigates, helicopters, a coastal radar network and submarines to gather evidence of the crimimal activities. On the other, it was supported by several humanitarian actors: the Fondazione Rava, the emergency services corps of the Order of Malta, the Italian Red Cross military corps and nurses, and Save the Children.

As I have shown in a previous article on the visual politics of this operation, speaking the language of combating human smuggling and potential terrorists, while rescuing lives and protecting migrants' human rights, Mare Nostrumperforms the spectacle of the 'humanitarian battlefield. ${ }^{37}$ The concept of 'humanitarian battl fi ld' can be better understood if we investigate the communication performances of Mare Nostrum withinwhat Chouliaraki defin s as a 'war imaginary': 'a structured configuration of representational practices, which produces specific performances of the battlefield at specific moments in time, with a view not only to informing and persuading us, as per the instrumental aspect of propaganda, but also to cultivating longer-term dispositions towards the visions of humanity that each war comes to defend. ${ }^{38}$ Assuming, with Chouliaraki, that the imaginary works performatively through a morality of virtue, that is, it draws upon familiar practices of aesthetic performance so as to engage spectators with images and stories aboutourworldand, thereby, to socialize us into those ways of feeling and acting that are legitimate and desirable in a specific culture', we see how these images contribute to influ ncing public perception, while shaping the social imaginary through moral discourses of care and responsibility. ${ }^{39}$

Theextent to which these images invite us to legitimise the operation(whichcosts EUR 9 million per month) becomes clear if we adopta visual framing approach that takes into account how the images of rescue operations are symbolically organised, the representational genres that they utilise to convey distant suff ring, and the sorts of ideological and aesthetic positioning of actors involved in this process. The 
Italian navy's choice of somekey words, phrases and images (as well as the omission of other elements that could suggest a diff rent perspective or trigger a diff rent sentiment) reinforces a particular representation of reality and a specific emotion towards it. Let me note that Mare Nostrum (our sea) was the Roman name for the Mediterranean Sea, picked up by Mussolini to frame fascist propaganda about the 'Italian lake'. As the same (ambivalent) name indicates, the possessive 'our' imagines the Mediterranean as a European space of care and control, while it ambiguously refers to both Italy and Europe. As most photographs available on the Italian navy's website make clear, the official visual narrative constructs borders at imaginary levels triggering sympathy for the soldiers and pity for the migrants. ${ }^{40}$ Th re are plenty of images that portray the soldiers' activities with the aimof drawing us into a community of witnesses. Emphasising practices and discourses of care, aid and assistance, soldiers covered this operation as a programme of humanitarian, national benevolence that institutes an 'imagined community' between spectators and soldiers from the same country: a community in which the spetator is positioned as the posible saviour, while the rescued bodies are the 'other.'1 $\mathrm{Th}$ ough such images it becomes clear that border control is being redefin $\mathrm{d}$ within a moral imagination that puts emphasis on human vulnerability. The soldiers' activities are depicted in the recurring imagery of aid delivery, with rescued, grateful migrants receiving food parcels and water. Women with tiny, innocent babies are the most commonlyrepresented subjects.

To what extent the legitimacy of the military-humanitarian operation Mare Nostrum depends on how it is described and explained through media becomes evident through the analysis of the official video of the operation ${ }^{42}$ It starts with silent images of a man drowning on the high seas, two black women desperately crying over a coffin hundreds of coffins on a vessel, emergency news commenting on shocking images of the Lampedusa shipwrecks, and the trembling voice of the Pope announcing: 'the onlyword I can say is: shame!' During these fi st twenty seconds, through silence and with no voiceover describing the action, nor explanation and context, just drama, the editing of the erratic shots constructs a compassionate narrative that appears as 'real-time story telling' made by intense images. We are invited to read the military-security dispositive of Mare Nostrum through the moral voice of the Pope - a religious authonity who is here reframed through a secular humanitarian narrative, continuing the sacred salvational marratives of rescue.

An intense apocalyptic musical score immediately erupts after the Pope's words. Following the visual quality of a Hollywood adventure, the rescuers arrive by helicopters, frigates and well-armed vessels, wearing uniforms and medical facemasks. Themusicgrows increasingly epic. Images of soldiers rescuing people in the high waves alternate with that of medical care interventions as the rescued reach the technologically highly equipped vessel. The visual focus is on soldiers distributing food to starving children and exhausted women; a mass of black men praying on the vessels, thankfully gazing at the camera (us). In the last shot we are faced with 
the smiling eyes of two grateful rescued children, with a signboard on which they have written: 'Thank you Italya'.

Furthermore, this rearticulation of the military as the humanitarian is even more evident in the docudrama co-produced by the Italian navy and broadcast at prime time in October 2014 by the Italian national television network (RAI): Catia's Choice: 80 Miles South of Lampedusa ${ }^{43}$ Catia Pellegrino is the (female) lead character of this ninety-two-minute docudrama, chronicling the rescue of refugees crossing borders during the last two months of the Mare Nostrum operation. Alternating images of the brave rescue operations with personal stories of the crew, the video focuses on the positive influ nce of Catia's strength and empathetic nature in serving others, while maintaining vigilance, keeping the seas safe on her watch.

Th ough the hyper-emotionalisation and psychologisation of the marines, these images project a moral agency of emotional fragility that humanises and 'feminizes' the armed forces within the realm of those needing 'protection. ${ }^{44}$ Emphasising the value of personal narratives, the marines appear closer to social workers than soldiers: social workers with guns. Ths attitude is in line with what Chouliaraki has defin d 'the empathetic soldiering self', which is infused with the spirit of benevolence and can be associated with the soldiers' effo $t$ to cultivate a military subjectivity that sees the 'other' as the self and is committed to protecting her/him as one of 'our own' - 'thereby, paradoxically perhaps, eff cting a new "civilianisation" of the military.45 To sum up, in the communication performances enacted by the Italian navy, the moralisation of the spectator takes place through a mechanism of aestheticisation of suff ring that is detached from any historical or geopolitical context.

\section{3,034: the number of fatalities in 2016}

In order to get a picture of the inability of European countries to act cohesively in the face of commonpressures at their southern shores, let me enrich the analysis with two diff rent pieces of news released on 28 July 2016. Focusing on the current tragedies in the Mediterranean Sea, both the initiatives invite us to refl ct on the eff ct of the media on public understanding of the so-called 'migration crisis'. On 28 July, Barcelona's mayor Ada Colau unveiled a large digital billboard showing the number of migrants and refugees who died in the Mediterranean Sea in $2016 .{ }^{46}$ The large metal rectangular pillar is located near one of the city's most popular beaches and comes with a digital counter that began with 3,034 - the number of fatalities that year. But, as the inscription on this 'monument of shame' states, 'Th s isn't just a number, these are people.' On the same day, Italy's interior minister, Angelino Alfano, launched a media campaign aimed at dissuading African migrants and refugees from making the unsafe journey to Europe over the Mediterranean ${ }^{47}$ Drawing upon the same estimated number of people killed that year while attempting to reach Italy's southern shore, the Aware Migrants campaign features news, articles and powerful 
video testimonials from refugees who made it to Italybut had to endure physicaland sexual abuse from people smugglers along the way. Developed in partnership with the International Organization for Migration (IOM), the campaign was launched in three languages - English, French and Arabic - on various platforms, including its own website, Facebook, YouTube, Twitter and Instagram.

As diff rent ways to framing current tragedies and raising awareness on what is happening in the Mediterranean, both the initiatives do not onlyreport on the world 'out there', butalso constitute this worldin meaning, opening up the space forcertain forms of intervention and the production of specific types of subjects. Assuming, as I did in the previous paragraph, that the military-humanitarian response to the political 'migration crisis' can be intended as a spectacle that invites us to look at the Mediterranean Sea as a 'humanitarian battlefield', the two initiatives make people 'aware' that there are diff rent ways of looking this liquid 'battlefield' in the face. Tracking the dramatic deaths in real time, the digital monument in Barcelona invites us 'to look the Mediterranean in the face andlook at this number', as Colau has said that '3,034 people who drowned because they were not off red a safe passage'. Th s radicalinitiative aims at making 'us' - European citizens - aware that our human fear towards these strangers, which often becomes open hostility and shameless xenophobia, and is expressed in racist prejudice and physicalviolence, is transforming the same blue sea of our relaxing holidays into a horrific graveyard. As such, it focuses on the pressures that these deaths are exerting in Europe upon the concept and practice of collective responsibility in order to expose our indff rence.

Thefocus on thetotal number of peoplethat died dueto diff rent causes (disasters, wars, inequality, bad policies, etc.) as a techniqueto denounce our normalised indifference is not new. Stats about deaths occurring in a specific place or withina certain amount of time have been aroundfor years. Being large figures notoriouslydifficult to visualise and imagine, the communication of humanitarianism usually focuses on the individual to humanise a problem. By using a short, accessible phrase that in a brief period of time will convey both the emotional impact of the tragedy and that sense of scale and ungency that will precipitate some kind of ation, NGOs and charities adopt those kinds of statistics to represent the horrifying image that grabs the headlines. In the Make Poverty History campaign, for example, a host of celebrities from the world of music, cinema and fashionappeared on a video clicking their fi gers at regular intervals. Th $\mathrm{n}$ the message was that 'A child dies unnecessarily as a result of extreme poverty every three seconds. ${ }^{48}$

A few years later, the promotional videos of Enough Food for Everyone IF campaign, featured the host, the comedian Eddie Izzard, saying: 'In every minute of every day, four children die of hunger. ${ }^{39}$ The WFP's video campaign A Time for Action claimed that 'Every six seconds a child dies of hunger. ${ }^{\text {' }}{ }^{5}$ What is new, in this case, is the effo $t$ to make sense of the emergence of death as a routine or normalised dimension of contemporary bordering practices between more and less stable and privileged regions. ${ }^{51}$ In its attempt to unveil the biophysicalviolence in 
any hierarchy of 'worthy' and 'unworthy' lives, Colau's initiative reminds us that, despite Enlightenment traditions and Kantian cosmopolitanism emphasising that 'every life matters' (as highlighted in the same motto of the search and rescue organisation MOAS), the EU is acting openlyhostile towards asylumseekers. ${ }^{52}$ It forces us to refl ct upon the fact that the ethics of responsibility are today suspended between European democracies' moral imperative to save the lives of people in need and an economy of indiff rence that, through denial and inaction in the sea, allows for the deaths of certain popultions to take place without sanctions or repercussions.

On the contrary, assuming that migration is a decision often based on false expectations ('many migrants leave theirhomewithouta concrete project of precise idea of the socioeconomicand political situation of theircountry of destination', said Aware Migrants), Alfano's campaign aims at making 'them' - i.e. would-be African migrants - aware that if they are aspiring to leave their home countries in search of better lives for themselves and their families, they will experience the dangers of violence and exploitation during their perilous journey. Drawing upon statistics on migrant deaths in various regions and from various causes in its effo $t$ to reduce the infl $\mathrm{x}$ of asylum-seekers, the campaign warns would-be migrants that their dream can 'end up a nightmare': the nightmare of women raped in front of their husbands in Libya, or people seeing loved ones die of thirst in the desert or drowning at sea. Furthermore, the news, articles and videos of the campaign advise potential newcomers from fifteen African countries (including the top three asylum-seeker suppliers to Italy - Nigeria, Eritrea and Sudan) that, even if they are strong andlucky enough to reach our shores, they need to convince us that they are really in need of international protection. Indeed, besides the stories of survivors who experienced terrible dangers to come to Europe, the campaign advises Africans that 60 per cent of refugees had their applications rejected last year because they were not deemed by authorities to be true refugees' $\mathrm{fl}$ eing war.

It is certainlytrue that, like Barcelona's mayor, Italy's interior minister recognises that 'Europe's migrant crisis is an epochal struggle', affirming that 'obviously, we pride ourselves on welcoming all those fl eing war'. Nevertheless, as he said, 'we can't welcome everybody. ${ }^{53}$ It is worth noting that the two initiatives adopt a 'necropolitical tool to tackle diff rent aspects of the same migrant crisis. ${ }^{54}$ While the Spanish mayor seeks to tackle the crisis of humanity that is aff cting European migration policies, urging everyone to awaken from indiff rence, Italy's interior minister seems to legitimate our ethical failure, highlighting that 'they' are unwanted and undeserved. If the former aims at convincing European citizens (and policymakers) to be more welcoming, the latter seeks to keep refugees out by making it clear that they are have notbeen invited, and that we aren't willing to welcome many newcomers. Targeting diff rent people but with the same aim of making them aware of the challenge of responsibility, the two initiatives appear to give opposite advice regarding the acceptance of immgrants. 'Don't turn a blind eye to poor and helpless people, they are in danger, we can avoid these deaths, it is our responsibility to help those who are 
victims of our hostile policies' Colau seems to be saying to the European audience. 'Open your eyes and do not even thinkof starting the journey, it is dangerous and you are (perceived as) a danger, the loss and suff ring you will go through is your own responsibility' - this is the veiled warning launched by Alfano and directed at the African audience. It is interesting to note that the EUR 1.5 million campaign is the latest of several attempts by Italy to convince fewer refugees to make the journey, with others including a deportation and relocation programme. Although this campaign focuses on reducing loss of life by informing migrants of the dangers of irregular routes, smuggling or traffi ing, in its attempt to use communication to discourage irregular migration Italy seems to follow Hungary and Denmark ${ }^{55}$ $\mathrm{Th} \mathrm{s}$ is not the fi st European fear-mongering campaign. Indeed, to limit the fl $\mathrm{w}$ of refugees, in 2015 the Hungarian government - besides the 112-mile-long fences along its border with Serbia - used advertising campaigns to actively dissuade refugees from entering the country. ${ }^{56}$ Theadvertisements were published in several Lebanese and Jordanian newspapers warning refugees not to attempt to enter Hungary illegally. The full-page advertisements, published in Arabic and English, warned that refugees caught entering the country illegally could face imprisonment. A few months later, the Danish government released a similar advertisement in major newspapers in Lebanon in whichit warned migrants not to come to the prosperous Nordic country, highlighting that those rejected for asylum would be deported from the country. It spent EUR 30,000 on an advertising campaign that emphasised the stringent regulations and constraints that await migrants. ${ }^{57}$ Probably to avoid accusations of drummirg up anti-immgrant rhetoric (as seen in the Hungarian and Danish cases), Italy's Minister of Interior decided to adopta more veiled warning to migrants; the involvement of the IOM, one of the main refugee rights groups that has called for better treatment of those choosing to make the joumey, represents a strong humanitarian aspect of the poject.

Angelino Alfano is the Interior Minister of the government led by Matteo Renzi, Italy's prime minister, who perfectly integrated the humanitarian discourse of assistance and hospitality within the ongoing language of migration governance. Alfano launched the campaign stressing that 'economicmigrants comprised 60 percent of last year's 154,000 arrivals', and noting that Italy and the rest of the EU 'must speed up the repatriation of migrants with no legal residency rights, otherwise the bloc's migrations policies will collapse'. Indeed, since 2015, Matteo Renzi has insisted that Italy and all of Europe had a humanitarian 'duty' to protect people making the journey. On 15 October 2015, for example, during his visit to the Italian parliament, the UN Secretary-General, Ban Ki-moon, paid homage 'to the Italian soldiers who saved thousands of human lives in the Mediterranean', and thanked 'the Italian popultion for the effots made to welcome and assist migrants'.

Concluding the event, Matteo Renzi affirmed: 'the Italy that welcomes you is the country of the Italian officers who became nurses to deliver babies in the ships on the Mediterranean. It is an Italy of which we are proud. ${ }^{58}$ Furthermore, 
on 7 March 2016, Renzi gave each EU leader at a migration summita DVD copy of Fuocoammare (Fire at Sea, Gianfranco Rosi, 2016), a documentary about the plight of refugees as they wash up on the shores of the Sicilian island of Lampedusa, which won the top prize at the 66th Berlin Film Festival. ${ }^{59}$ At the same time, Renzi - like most European leaders - is keen to show he is taking steps to diff rentiate between refugees who are fl eing war, and those who are seeking a better life and economic opportunities. Despite the fact that - as the GSDRC research report shows - there is extremely scant evidence on whether these campaigns are eff ctive, and anecdotal evidence suggests that they have limited, if any, eff ct on migrants' decisions to leave, ${ }^{60}$ these initiatives represent a further example of how media performances contribute to shaping the Mediterranean as an emotional and physical setting in which fears and insecurities can be used for both progressive as well as regressive purposes. $^{61}$

\section{Conclusion}

In my attempt to critically make sense of the political stakes surrounding European borders, in this chapter I have explored several examples of initiatives that may appear paradoxical and mutually contradictory, but - this is my suggestion - are part of the complex dichotomies of care and control, the absence and presence of law, transparency and darkness, solidarity and indiff rence, which mark contemporary border regimes. Theintricate role of humanitarian narrative and the human rights discourse in Frontex's operational activities of border control; the language of combating human smuggling while rescuing lives, currently adopted by the Italian navy; the digital billboard that counts the number of people who have died in the Mediterranean Sea in 2016; the media campaign aimed at dissuading African would-be migrants from making the unsafe joumey to Europe launched by Italy's Interior Minister; Matteo Renzi's emphasis on the humanitarian duty to protect people making the joumey: these examples suggest, on the one hand, that the discourse of assistance and solidarity has been perfectlyintegrated withinthe ongoing language of migration governance. On the other hand, it shows that coercive policies of control, which directly and indirectly contribute to the precariousness of life, co-exist with a humanitarian self-perception by European member states and EU agencies.

Drawing attention to the biopolitical, thanatopolitical and necropolitical dimensions of contemporary border practices as these operate in the Mediterranean Sea, this chapter invites to refl ct on the co-existence of the humanitarian narratives of saving lives and the increasingly militarised borders, as well as the misperception of our own role and responsibility in this routine production of deaths. In examining the contradictory tension between diff rent initiatives, discourses and practices of border reinforcement and border crossing, it shows how the ethics of security is intrinsically related to geopolitical reason. 
Indeed, looking at the integration of humanitarian narrative in the language of security deployed by European and national actors, it would seem that the primary subject of security (i.e. deserving of protection) is the citizenry of the EU. Migrants and asylum-seekers do not feature as objects of state knowledge, either on the EU level or on the leel of indvidual member states.

Thus, on the one hand, by enabling us to imagine ourselves as compassionate citizens who have both the capacity to save migrants in the high seas, and to defend our countries from the invasion of the aliens, the mediated nature of the humanitarian assistance results in undermining rather than intensifying solidarity. ${ }^{62}$ On the other hand, by seeing the deaths in the Mediterranean onlyin terms of crisis, while depicting the Mediterranean as a place where the 'state of exception' takes place and migrants are reduced to 'bare life' - excluded from the sphere of human values, civic rights and moral obligations - contributes to obscure the structural role of European border policies and everyday practices in these deaths. ${ }^{63}$ As such, the consolidation of Europe's external borders, the implementation of Schengen and the restrictive visa regime, as well as the consequences on people's ability to seek safe and legal routes into the EU, becomes invisible. Indeed, if the governance of migration is reduced to a humanitarian question of saving lives and to a question of combating the smugglers, its technociatic management appears to be beyond politics. In spite of the humanitarian rhetoric often employed or the declared aim to target smugglers and traffi ers, several scholarly analyses have demonstrated that no naval operation in the Mediterranean has made passage more secure for migrants. ${ }^{64}$ On the contrary, the emergency management of the crisis has led to a situation in which tens of thousands of migrants and refugees are stranded in Greece and Turkey because crossing the Mediterranean has becomemore and more dangerous and expensive. TheEU's border regime has funnelled migratory fl ws towards longer and more perilous routes as migrants seek to avoid detection, detention and/or retum. Th se displacement eff cts, by now very predictable and foreseeable, have contributed to a terrible human toll.

Despite the emotional and technocratic framing usually adopted by the media to describe the Mediterranean as a depoliticised border, we must be aware about what Mezzadra and Neilson call the 'productive' and even 'creative' functions of the borders, which means the specific forms of 'order' they enable within the space they appear to merely circumscribe. ${ }^{65}$ As they argue, the 'encounter' of a would-be migrant with the border, its crossing, tends to reproduce itself across large parts of that experience and biography, with multiple manifestations of the border haunting migrants in their negotiations with citizenship and labour markets, in the urban as well as the 'national' spaces theyinhabit and to which they contribute and thus transform and produce. Since the birth of the EU, this 'productive' nature of borders has played crucial roles in the establishment and constitution of a European space. Yet, in the current situation it is nurturing a 'compassionate repression' that increasingly and silently legitimises the diff rence between the 'us' (the figure of the citizen) and the 'them' (the figure of the foreigner'). ${ }^{66}$ 
Amongst the 'existential' questions that are at stake for the EU integration process as a whole, it is fundamental to consider that migration to Europe will continue over the coming years, both because of the push of migrants and because European economies and societies need migration ${ }^{67}$ As it is confi med by demographic as well as economic reports, Europe needs more migrants, not fewer. ${ }^{68}$ Thus, the EU's politicalelites shouldunderstand the absolute necessity of att acting more migrants, and co-operate to convince voters that Europe's future is at stake. Stopping migration is not only an unrealistic prospect that produces concrete eff cts in the everyday life of millions of vulnerable people on the move. It also contributes to worsen the conditions under which migration will happen in the near future as well as of the lives of migrants already established in Europe. If we really wish to save lives and to come up with better responses to meet the tremendous needs people face risking the dangerous journey it probably would be better for EU governments to turn the core question from 'how can we stop migrants?' to 'why are people fl eing?' and 'how can we provide people with the ability to apply for visas/asylum hwfully?'

\section{Notes}

1 Although there is a crucial legal diff rence between 'migrant' and 'refugee', it is worth noting that in the media these terms are often used interchangeably, depending on the period and its public sentiment (e.g. according to Google Trends data, throughout 2015 , searches for 'refugee' remained slightly higher than 'migrant' spiking in early September, around the time the distressing photos of Alan Kurdi were released). Moreover, although the legal and political separation between refugees, asylum-seekers and migrants is ever-present in the communitarian discourse and agenda-setting, the diff rence - upon which not everybody agrees, and that has received criticism by the double standard it imposes upon people in need, producing a selective recognition of suff ring - is much more blurred in practice. According to this, it is interesting the announcement by $\mathrm{Al}$ Jazeera English it would stop using the term migrant, as it 'is nolonger fit for purpose when it comes to describing the horror unfolding in the Mediterranean'. See L. Westcott, 'Refugees vs. Migrants: What's the Right Term to Use', Newsweek (11September 2015), www.newsweek.com/refugee-vs-migrants-whats-right-term-use-37 222. Accessed 15 July 2017.

2 S. Castles and M. J. Miller, The Age of Migration: International Population Movements in the Modern World (Basingstoke: Palgrave Macmillan, 2009); K. Moore, B. Gross and T. R. Th eadgold (eds), Migrations and the Media: Global Crises and the Media (New York: Peter Lang, 2012).

3 R. Andersson, Illegality, Inc.: Clandestine Migration and the Business of Bordering Europe (Oakland: University of California Press, 2014); M. Tazzioli, Spaces for Governmentality, Autonomous Migration and the Arab Uprisings (London: Rowman \& Littlefield International, 2015).

4 Wikipedia is publishing the monthly timelinelist of terrorist incidents which took place in 2016, including attacks by violent non-state actors for political, religious, economic,ethnic, nationalistic, other or unknown motives: see https:// en.wikipedia.org/wiki/List_of_terrorist_ incidents,_2016. Accessed 15 July 2017.

5 'IslamicState's (ISIS, ISIL) Magazine,' Clarion Project, 10 September 2014, www.clarionproject. org/news/islamic-state-isis-isil-propaganda-magazine-dabiq. Accessed 15 July 2017. 
6 D. Bigo, 'Security and Immigration: Toward a Critique of the Governmentality of Unease', Alternatives: Global, Local, Political, 27:1(2002), pp. 63-92; S. Mezzadra and B. Nielson,Border as Method, or, Multiplication of Labour (Durham, NC and London: Duke University Press, 2013).

7 N. Vaughan-Williams, 'Borderwork beyond Inside/Outside? Frontex, the Citizen-Detective and the War on Terror', Space and Polity, 2:1 (2008), pp. 63-79.

8 M. Albahari, Crimes of Peace: Mediterranean Migrations at the World's Deadliest Border (Philadelphia: University of Pennsylvania Press, 2015).

9 P. Musarò, “Africans" vs. "Europeans": Humanitarian Narratives and the Moral Geography of the World, Sociologia della Comunicazione, 45 (2013), pp. 37-59; P. Cuttitta, 'Borderizing the Island: Setting and Narratives of the Lampedusa Border Play', Acme: An International E-Journal for Critical Geographies, B:2 (2014), pp 196-219.

10 P. Musarò and P. Parmiggiani, Media e migrazioni: Etica, estetica e politica della narrazione umanitaria (Milan: FrancoAngeli, 2014).

11 M. Casas-Cortes et al., 'New Keywords: Migration and Borders', Cultural Studies, 29:1 (2015), pp. 55-87.

12 As De Genova argues: 'these putative "elsewheres" are systematically represented as historically sanitised, which is to say, shom of their deeply European (post)colonial histories as well as disarticulated from the European political and economicinterests implicated in producing and sustaining their fractured presents.' N. De Genova, 'The "Crisis" of the European Border Regime: Towards a Marxist Th ory of Borders', International Socialism: A Quarterly Review of Socialist Theory, 150 (4 April 2016), http:// isj.org.uk/the-crisis-of-the-european-borderregime-towards-a-marxist-theory-of-borders/\#footnote-10080-28. Accessed 15 July 2017.

13 M. Cebeci and T. Schumacher, 'Deconstructing the EU's Discourse on the Mediterranean', Medreset, 2 (2016), pp. 1-18.

14 M. Kurki, 'Democracy Th ough Technocracy? Refl ctions on Technocratic Assumptions in EU Democracy Promotion Discourse', Journal of Intervention and Statebuilding, 5:2 (2011), p. 216.

15 P. Shields, 'TheHuman Cost of the European Union's External Border Regime', Peace Review, 27:1 (2015), p. 86.

16 L. Weber andS. Pickering, Globalization and Borders: Death at the Global Frontier (Basingstoke: Palgrave Macmillan, 2011)

17 Th re are now a dozen such humanitarian shipsplaying a big role in the Mediterranean crisis, chartered by MOAS, Doctors Without Borders (MSF), SOS Mediterranee, the Catalan Proactiva Open Arms and German Sea-Watch, Sea-Eye and Jugend Rettet: http:// reliefweb. $\mathrm{int} /$ report/world/small-aid-ships-play-big-role-europes-migrant-crisis. Accessed 15 July 2017.

18 C. Calhoun, 'The Idea of Emergency: Humanitarian Action and Global (Dis)Order', in D. Fassin and M. Pandolfi (eds), Contemporary States of Emergency: The Politics of Military and Humanitarian Interventions (New York: Zone Books, 2010), pp. 29-58.

19 J. Jeandesboz and P. Pallister-Wilkins, 'Crisis, Enforcement and Control at the EU Borders', in A. Lindley (ed.), Crisis and Migration: Critical Perspectives (London: Routledge, 2014), pp. $115-35$

20 M. Foucault, Society Must Be Defended: Lectures at the Collegge de France, 1975-76, ed. M. Bertani and A. Fontana, trans. David Macey (London: Penguin, 1997); G. Agamben, Homo Sacer: Sovereign Power and Bare Life, trans. Daniel Heller-Roazen (Stanford: Stanford University Press, 1998); A. Mbembe, 'Necropolitics', Public Culture, 15:1 (D003), pp 11-40.

21 For example, A. Estevez, 'The Politics of Death and Asylum Discourse: Constituting Migration Politics from the Periphery', Alternatives, 39:2 (2014), pp. 75-89; Vaughan-Williams, 
'Borderwork beyond Inside/Outside?'; V. Squire, 'Governing Migration through Death in Europe and the US: Identific tion, Burial, and the Crisis of Modern Humanism', European Journal of International Relations (16 March 2016), pp. 1-20.

22 W. Walters, 'Foucault and Frontiers: Notes on the Birth of the Humanitarian Border', in U. Bröckling, S. Krasmann and T. Lemke (eds), Governmentality: Current Issues and Future Challenges (New York: Routledge, 2011), pp B8-64.

23 See www.frontexit.org/ en/. Accessed 15 July 2017.

24 The Berlusconi government used the 'state of emergency' as an ad hoc measure to bypass ordinary political procedures and release public money. During the North Africa Emergency, which delegated extraordinary powers to the Civil Protection to manage the situation, over $€ 15$ billion were allocated to fund makeshift reception centres and hotel accommodation distributed across Italy for 21,000 asylum seekers. See M. Sasso and F. Sironi, 'Inchiesta: Chi specula sui profughi, L'Espresso, 15 October 2012, http:// espresso.repubblica.it/attuaita/ cronaca/2012/ 10/ 15/news/ chi-specula-sui-profughi-1.47304. Accessed 15 July 2017.

25 T. E. Aalberts and T. Gammeltoft-Hansen, 'Sovereignty at Sea: The Law and Politics of Saving Lives in Mare Liberum', Journal of International Relations and Development, 17 (2014), pp. 439-68.

26 Vaughan-Willams, 'Borderwork beyond Inside/Outside?', p. 66.

27 A. W. Neal, 'Securitization and Risk at the EU Border: The Origins of Frontex', Journal of Common Market Studies, 47 (2009), pp. 333-56.

28 As Amnesty International denounces: 'The EU's priorities regarding migration policy have focused on sealing its borders rather than its human rights obligations. Th s can be clearly seen in expenditure on constructing "Fortress Europe" as compared with the funding given for supporting asylum procedures and the needs of refugees.' The Human Cost of Fortress Europe: Human Rights Violations Against Migrants and Refugees at Europe's Borders (London: Amnesty International, 2014), p. 9, www.amnesty.ch/de/themen/asyl-migration/ europa/ dok/ 2015/ Die-Kampagne-SOS-Europa/ bericht-the-human-cost-of-fortress-Europe. Accessed 15 July 2017.

29 K. Horsti, 'Humanitarian Discourse Legitimating Migration Control: FRONTEX Public Communication', in M. Messier, R. Wodakand R. Schroeder (eds), Migrations: Interdisciplinary Perspectives (Vienna: Springer Science and Business Media, 2012), pp. 297-308.

30 Frontex, Annual Risk Analysis Units, 2013: http:// frontex.europa.eu/assets/Publications/ Risk_Analysis/Annual_Risk_Analysis_2013.pdf, p. 7. Accessed 4 November 2015.

31 As the Deputy Executive Director Gil Arias Fernandez argues: 'Facilitators lure these desperate people with the promise of an easy crossing and a better life, and charge up to USD 7,500 for a trip from Afghanistan. Th s is not always the case. Tragically, since the beginning of the year 41 people lost their lives trying to cross the Evros river or the sea in the area of Alexandropouli, many more die as a result of the dangerous forms of transport used by unscrupuloussmugglers, others still end up victims of traffi ing for the sex trade or in forced labour', quoted in Horsti, 'Humanitarian Discourse Legitimating Migration Control', p. 305.

32 K. F. Aas and H. O. I. Gundhus, 'Policing Humanitarian Borderlands: Frontex, Human Rights and the Precariousness of Life', British Journal of Criminology, 55 (2015), pp 1-18.

33 Aas and Gundhus, 'Policing Humanitarian Borderlands', p. 14.

34 D. Fassin and M. Pandolfi, Contemporary States of Emergency: The Politics of Military and Humanitarian Interventions (New York: Zone Bodks, 2010).

35 Hermes controlled the border along the Italian coastline, while Aeneas controlled migrant flows. 
36 'Mare Nostrum Operation', Ministero Della Difesa, www.marina.difesa.it/EN/ operations/ Pagine/MareNostrum.aspx. Accessed 15 July 2017.

37 P. Musarò, 'A Humanitarian Battlefield: Redefini g Border Control as Saving Victims', Open Democracy (1 June 2016), www.opendemocracy.net/mediterranean-joumeys-in-hope/pierluigimusar/humanitarian-battlefield-redefini ion-of-border-control-in-aid-of-victims. Accessed 15 July 2017.

38 L. Chouliaraki, 'The Humanity of War: Iconic Photojoumalism of the Battlefield, 1914-2012', Visual Communication, $2: 3$ (2013), p. 318 .

39 L. Chouliaraki, The Ironic Spectator: Solidarity in the Age of Post-Humanitarianism (Cambridge: Polity Press, 2012), p. 44.

40 See www.marina.difesa.it/_layouts/15/MMIV2-Layouts/pages/MMI.GalleriaFullscreen. aspx?PageId=1f721c47-dd5d-408d-82ad-226b3a03c23e\&Guid=a3cdcf80 - 1680-4816-9ef3b89ae03a5236 and 'MARE NOSTRUM: Un anno di soccorsi, aiuti e contrasto ai traffi nti di uomin' Ministero Della Difesa, 24 October 2014, www.marina.difesa.it/conosciamoci/ notizie/ Pagine/20141024_annomarenostrum.aspx. Accessed 15 July 2017.

41 B. Anderson, Imagined Communities: Reflections on the Origins and Spread of Nationalism (London: Verso, 1991).

42 Marina Militare, 'Marina Militare - Video su operazione Mare', 25 July 2014, www.youtube. $\mathrm{com} /$ watch? $\mathrm{v}=\mathrm{H} 7 \mathrm{LWma67WAA}$. Accessed 15 July 2017.

43 Rai, 'La scelta di Catia - Lunedì 6 ottobre alle 21:05su', 2 October 2014, www.youtubecom/ watch?v=0MWdxuG0Qo. Accessed 15 July 2017.

44 C. Masters, 'Bodies of Technology: Cyborg Soldiers and Militarized Masculinities', International Feminist Journal of Politics, 7:1 (D05), p 114

45 L. Chouliaraki, 'From War Memoirs to Milblogs: Language Change in the Witnessing of War, 1914-2014, Discourse \& Society, 25:5 (D14), p 615.

46 'Barcelona Unveils Digital “Shame Counter" to Track Refugee Deaths', Guardian, 29 July 2016, www.theguardian.com/world/2016/ jul/29/ barcelona-unveils-digital-shame-counter-totrack-refugee-deaths. Accessed 15 July 2017.

47 www.awaremigrants.org. Accessed 15 July 2017.

48 Stephen Judge, 'Make Poverty History - Click', 13 July 2006, www.youtubecom/ watch?v=gFfIIW_xQq4. Accessed 15 July 2017.

49 Enough Food For Everyone IF, 'Eddie Izzard: Nutrition Summit Saturday 8 June', 6 June 20 13, www.youtubecom/watch?v=1W5b96QvS4. Accessed 15 July 2017.

50 'Timefor Action?', World Food Programme, 10 June 2007, www.wfp/ org/ videos/ time-action. Accessed 15 July 2017.

51 Squire, 'Governing Migration though Death in Furope and theUS'.

52 MOAS was established in 2013 by Christopher and Regina Catrambone as the fi st private rescue service organization to assist refugees at sea. See www.moas.eu/. Accessed 15 July 2017.

53 ' "Can't welcome everyone": Italy Launches $€ 15 \mathrm{mnOnline} \mathrm{Project} \mathrm{to} \mathrm{Deter} \mathrm{Migrants',} 28$ July 2016, www.rt.com/news/353746-italy-migrants-aware-campaign/. Accessed 15 July 2017.

54 Mbembe, 'Necropolitics'.

55 Before the EU governments, on July 2013 Australian customs and border protection launched a series of advertisements to educate and inform asylum-seekers, including unaccompanied minos, in source countries about the futility of investing in people smugglers, the perils of the trip, and the hardline policies that await them if they do reach Australian shores (www.border. gov.au/about/operation-sovereign-borders/ counter-people-smuggling-communication). Thecampaign, which has been criticised as one of the harshest border policies in the worldby 
human rights groups for its perceived bigotry and disregard for human life, was predominantly conducted online featuring a video message that has the commander of Operation Sovereign Borders, Lieutenant General Angus Campbell, standing next to a sign declaring 'NO WAY' in bold red letters over an ominousbackgroundfeaturing a small rickety boat on a churning sea. 'Themessage is simple, if you come to Australia illegally by boat, there is no way you will ever make Australia home', he says. See ABF TV, 'No Way. You Will Not Make Australia Home English', 15 April 2014, www.youtubecom/watch?v=rT12WH4a92w Accessed 15 July 2017.

56 T. Ana, 'Hungary's "Warning to Migrants" Highlights European Anti-Refugee Propaganda', Muftah (13 October 2015), http:// muftah.org/hungarys-anti-refugee-advertisements/\#.V6R ivq713E8 Accessed 15 July 2017.

57 W. Frej, 'Here Are The European Countries That Want To Refuse Refugees', Huffington Post (9 September 2015), www.huffingtonpost.com/entry/ europe-refugees-not-welcome_us_55ef3 dabe4b093be5lbc824. Accessed 15 July 2017.

58 A. Zampaglione, “"Thanks for 60 years of Italy-UN partnership”, said Ban Ki-moon in Rome', 15October 2015, www.onuitalia.com/eng/ 2015/10/ 15/thanks-for-60-years-of-italy-un-partnershipsaid-ban-ki-moonin-rome/. Accessed 15 July 2017.

59 'Renzi Gives EU Leaders Copies of "Fire at Sea"', 7 March 2016, www.ansa.it/english/ news / 20 16/ 03/07/ renzi-gives-eu-leaders-copies-of-fire-at-sea_d34fa393-dc9c-4f67-af41e8df7308558fhtml. Accessed 15 July 2017.

60 Although the Italian campaign seems to adopt some factors which, according to UNHCR, may improve the eff ctiveness of these campaigns - like targeting a specific group of migrants, engaging real-life testimonies from retumed migrants, and using celebrities to convey the message, like the Malian artist Rokia Traoré who accepted the invitation to participate in the project - the absence of information about legal opportunities and the missing trust in the information received are amongst the main reasons that limit eff ct on migration behaviour As the GSDRC Report argues, 'awareness campaigns may be irrelevant to prospective migrants who consider the attempt at changing their life to justify the risks involved. www.gsdrc.org/ publications/ impactof-communication-campaigns-to-deter-irregular-migration/ . Accessed 15 July 2017.

61 E. Browne, Impact of Communication Campaigns to Deter Irregular Migration, GSDRC Helpdesk Research Report 248 (Birmingham: GSDRC, 2015).

62 Musarò, "Africans" vs. "Europeans".

63 T. Basaran, 'The Saved and the Drowned: Governing Indiff rence in the Name of Security', Security Dialogue, 46:3 (2015), pp 205-20.

64 C. Heller and L. Pezzani, 'Ebbing and Flowing: The EU's Shifting Practices of (Non-) Assistance and Bordering in a Time of Crisis', Near Futures Online, 1(March 2016), 'Europe at a Crossroads', http:// nearfuturesonline.org/ ebbing-and-fl wing-the-eus-shifting-practicesof-non-assistance-and-bordering-in-a-time-of-crisis/. Accessed 15 July 2017; G. Garelli and M. Tazzioli, 'Warfare on the Logistics of Migrants Movements: EU and Nato Military Operations in the Mediterranean', Open Democracy (16 June 2016), www.opendemocracy.net/ mediterranean-journeys-in-hope/glenda-garelli-martina-tazzioli/ warfare-on-logistics-ofmigrant-movem. Accessed 15 July 2017.

65 Mezzadra and Nielson, Border as Method.

66 D. Fassin, Humanitarian Reason: A Moral History of the Present, trans. R. Gomme (Berkeley, Los Angeles and London: University of California Press, 2012).

67 M. Bojadžijev and S. Mezzadra, "'Refugee Crisis” or Crisis of European Migration Policies?' Focaalblog, 12 November 2015, www.focaalblog.com/2015/11/12/manuela-bojadzijev-andsandro-mezzadra-refugee-crisis-or-crisis-of-european-migration-policies/. Accessed 15 July 2017; É. Balibar, Europe, crise et fin? (Paris: Le Bord de PEau, 2016). 
68 G. Merritt, 'The efugee Crisis: Europe Needs More Migrants, Not Fewer', Europe's World, 26 October 2015, http:// europesworld.org/2015/10/26/the-refugee-crisis-europe-needs-moremigrants-not-fewer/\#.V8AfnK713E8 Accessed 15 July 2017.

\section{References}

Aalberts, T. E. and T. Gammeltoft-Hansen, 'Sovereignty at Sea: The Law and Politics of Saving Lives in Mare Liberum', Journal of International Relations and Development, 17 (2014), pp. 439-68.

Aas, K. F. and H. O. I. Gundhus, 'Policing Humanitarian Borderlands: Frontex, Human Rights and the Precariousness of Life', British Journal of Criminology, 55 (2015), pp 1-18.

ABF TV, 'No Way. You Will Not Make Australia Home - English', 15 April 2014, www.youtube. $\mathrm{com} /$ watch? $\mathrm{v}=\mathrm{r}$ 12WH4a92w Accessed 15 July 2017.

Agamben, G., Homo Sacer: Sovereign Power and Bare Life, trans. D. Heller-Roazen (Stanford: Stanford University Press, 1998).

Albahari, M., Crimes of Peace: Mediterranean Migrations at the World's Deadliest Border (Philadelphia: University of Pennsylvania Press, 2015).

Amnesty International, The Human Cost of Fortress Europe: Human Rights Violations Against Migrants and Refugees at Europe's Borders (London: Amnesty International, 2014), www. amnesty.ch/de/themen/asyl-migration/europa/ dok/2015/Die-Kampagne-SOS-Europa/ bericht-the-human-cost-of-fortress-Europe. Accessed 15 July 2017.

Ana, T., 'Hungary’s “Warning to Migrants" Highlights European Anti-Refugee Propaganda', Muftah (13 October 2015), http:// muftah.org/hungarys-anti-refugee-advertisements/\#.V6Rivq713E8 Accessed 15 July 2017.

Anderson, B., Imagined Communities: Reflections on the Origins and Spread of Nationalism (London Verso, 1991).

Andersson, R., Illegality, Inc.: Clandestine Migration and the Business of Bordering Europe (Oakland: University of California Press, 2014).

Balibar, É., Europe, crise et fin? (Paris: Le Bord de PEau, 2016).

'Barcelona Unveils Digital "Shame Counter" to Track Refugee Deaths', Guardian, 29 July 2016, www.theguardian.com/ world/ 20 16/ jul/ 29/ barcelona-unveils-digital-shame-counter-totrack-refugee-deaths. Accessed 15 July 2017.

Basaran, T., 'The Saved and the Drowned: Governing Indiff rence in the Name of Security', Security Dialogue, 46:3 (2015), pp 205-20.

Bigo, D., 'Security and Immigration: Toward a Critique of the Governmentality of Unease', Alternatives: Global, Local, Political, 27:1 (2002), pp.63-92.

Bojadžijev, M. and S. Mezzadra, " "Refugee Crisis" or Crisis of European Migration Policies?, Focaalblog, 12 November 2015, www.focaalblog.com/2015/11/12/manuela-bojadzijev-andsandro-mezzadra-refugee-crisis-or-crisis-of-european-migration-policies/ . Accessed 15 July 2017.

Browne, E., Impact of Communication Campaigns to Deter Irregular Migration, GSDRC Helpdesk Research Report 248 (Birmingham: GSDRC, 2015).

Calhoun, C., 'The Idea of Emergency: Humanitarian Action and Global (Dis)Order', in D. Fassin and M. Pandolfi (eds), Contemporary States of Emergency: The Politics of Military and Humanitarian Interventions (New York: Zone Bodks, 2010), pp. 29-58.

Casas-Cortes, M., S. Cobarrubias, N. De Genova, G. Garelli, G. Grappi, C. Heller, S. Hess, B. Kasparek, S. Mezzadra, B. Neilson, I. Peano, L. Pezzani, J. Pickles, F. Rahola, L. Riedner, 
S. Scheel and M. Tazzioli, 'New Keywords: Migration and Borders', Cultural Studies, 29:1 (2015), pp 55-87.

Castles, S. and M. J. Miller, The Age of Migration: International Population Movements in the Modern World (Basingstoke: Palgrave Macmillan, 2009).

Cebeci, M. and T. Schumacher, 'Deconstructing the EU's Discourse on the Mediterranean', Medreset, 2 (2016), pp. 1-18.

Chouliaraki, L., The Ironic Spectator: Solidarity in the Age of Post-Humanitarianism (Cambridge: Polity Press, 2012).

Chouliaraki, L., 'The Humanity of War: Iconic Photojournalism of the Battlefield, 1914-2012', Visual Communication, $2: 3$ (2013), pp 315-40.

Chouliaraki, L., 'From War Memoirs to Milblogs: Language Change in the Witnessing of War, 1914-2014, Discourse \& Society, 25:5 (D14), pp 600-18.

Cuttitta, P., 'Borderizing the Island: Setting and Narratives of the Lampedusa Border Play', Acme: An International E-Journal for Critical Geographies, B:2 (2014), pp 196-219.

De Genova, N., "The "Crisis" of the European Border Regime: Towards a Marxist Th ory of Borders', International Socialism: A Quarterly Review of Socialist Theory, 150 (4 April 2016), http:// isj.org.uk/the-crisis-of-the-european-border-regime-towards-a-marxist-theory-ofborders/\#footnote-10080-28. Accessed 15 July 2017.

Estevez, A., 'The Politics of Death and Asylum Discourse: Constituting Migration Politics from the Periphery', Alternatives, 39:2 (2014), pp 75-89.

Fassin, D., Humanitarian Reason: A Moral History of the Present, trans. R. Gomme(Berkeley, Los Angeles and London: University of California Press, 2012).

Fassin, D. and M. Pandolfi, Contemporary States of Emergency: The Politics of Military and Humanitarian Interventions (New York: Zone Books, 2010).

Foucault, M., Society Must Be Defended: Lectures at the College de France, 1975-76, ed. M. Bertani and A. Fontana, trans. D. Macey (London: Penguin, 1997).

Frej, W., 'Here Are The European Countries That Want To Refuse Refugees', Huffington Post (9 September 2015), www.huffingtonpost.com/entry/ europe-refugees-not-welcome_us_ 55ef3dabe4b093be51bc824. Accessed 15 July 2017.

Garelli, G. andM. Tazzioli, 'Warfare on theLogistics of Migrants Movements: EU and Nato Military Operations in the Mediterranean', Open Democracy (16 June 2016), www.opendemocracy. net/ mediterranean-journeys-in-hope/ glenda-garelli-martina-tazzioli/ warfare-on-logisticsof-migrant-movem. Accessed 15 July 2017.

Heller, C. and L. Pezzani, 'Ebbing and Flowing: TheEU's Shifting Practices of (Non-) Assistance and Bordering in a Time of Crisis', Near Futures Online, 1 (March 2016), 'Europe at a Crossroads', http:// nearfuturesonlineorg/ ebbing-and-fl wing-the-eus-shifting-practicesof-non-assistance-and-bordering-in-a-time-of-crisis/ . Accessed 15 July 2017.

Horsti, K., 'Humanitarian Discourse Legitimating Migration Control: FRONTEX Public Communication, inM. Messier, R. WodakandR.Schroeder(eds), Migrations: Interdisciplinary Perspectives (Vienna: Springer Science and Business Media, 2012), pp. 297-308.

'Islamic State's (ISIS, ISIL) Magazine', Clarion Project, 10 September 2014, www.clarionproject. $\mathrm{org} /$ news/islamic-state-isis-isil-propaganda-magazine-dabiq. Accessed 15 July 2017.

Jeandesboz, J. and P. Pallister-Wilkins, 'Crisis, Enforcement and Control at the EU Borders', in A. Lindley (ed.), Crisis and Migration: Critical Perspectives (London: Routledge, 2014), pp. $115-35$

Kurki, M., 'Democracy Th ough Technocracy? Refl ctions on Technocratic Assumptions in EU Democracy Promotion Discourse', Journal of Intervention and Statebuilding, 5:2 (2011), pp. $211-34$. 
'Mare Nostrum: Un anno di soccorsi, aiuti e contrasto ai traffi nti di uomin' Ministero Della Difesa, 24 October 2014, www.marina.difesa.it/conosciamoci/notizie/ Pagine/20141024_ annomarenostrum.aspx. Accessed 15 July 2017.

Marina Militare, 'Marina Militare - Video su operazione Mare', 25July 2014, www.youtubecom/ watch? $\mathrm{v}=\mathrm{H} 7 \mathrm{LWma67WAA}$. Accessed 15 July 2017.

Masters, C., 'Bodies of Technology: Cyborg Soldiers and Militarized Masculinities', International Feminist Journal of Politics, 7:1 (D05), pp 112-32.

Mbembe, A., 'Necropolitics', Public Culture, 15:1 (D003), pp 11-40.

Merritt, G., 'The Refugee Crisis: Europe Needs More Migrants, Not Fewer', Europe's World, 26 October 2015, http:// europesworld.org/ 2015/ 10/ 26/the-refugee-crisis-europe-needs-moremigrants-not-fewer/\#.V8AfnK7l3E8 Accessed 15 July 2017.

Mezzadra, S. and B. Nielson, Border as Method, or, Multiplication of Labour (Durham, NC and London: Duke University Press, 2013).

Moore, K., B. Gross and T. R. Th eadgold (eds), Migrations and the Media: Global Crises and the Media (New York: Peter Lang, 2012).

Musarò, P., "Africans" vs. "Europeans": Humanitarian Narratives and the Moral Geography of the World, Sociologia della Comunicazione, 45 (2013), pp 37-59.

Musarò, P., 'A Humanitarian Battlefield: Redefini g Border Control as Saving Victims', Open Democracy (1 June 2016), www.opendemocracy.net/mediterranean-journeys-in-hope/ pierluigi-musar/humanitarian-battlefield-redefini ion-of-border-control-in-aid-of-victims. Accessed 15 July 2017.

Musarò, P. and P. Parmiggiani, Media e migrazioni: Etica, estetica e politica della narrazione umanitaria (Milan: FrancoAngeli, 2014).

Neal, A. W., 'Securitization and Risk at the EU Border: TheOrigins of Frontex', Journal of Common Market Studies, 47 (2009), pp. 333-56.

Rai, 'La scelta di Catia - Lunedì 6 ottobre alle 21:05 su', 2 October 2014, www.youtubecom/ watch?v=0MWWdxuG0Qo. Accessed 15 July 2017.

'Renzi Gives EU Leaders Copies of "Fire at Sea"', 7 March 2016, www.ansa.it/english/news/20 16/ 03/07/ renzi-gives-eu-leaders-copies-of-fi e-at-sea_d34fa393-dc9c-4f67-af41 e8df7308558f. html. Accessed 20 July 2016.

Sasso, M. and F. Sironi, 'Inchiesta: Chi specula sui profughi', L'Espresso, 15 October 2012, http:// espresso.repubblica.it/attualita/ cronaca/2012/ 10/ 15/news/ chi-specula-sui-profughi1.47304. Accessed 15 July 2017.

Shields, P., 'TheHuman Cost of the European Union’s External Border Regime', Peace Review, 27:1 (2015), pp 82-90.

Squire, V., 'Governing Migration through Death in Europe and the US: Identific tion, Burial, and the Crisis of Modern Humanism', European Journal of International Relations (16 March 2016), pp. 1-20.

Tazzioli, M., Spaces for Governmentality, Autonomous Migration and the Arab Uprisings (London: Rowman \& Littlefield International, 2015).

Vaughan-Williams, N., 'Borderworkbeyond Inside/Outside? Frontex, the Citizen-Detective and the War on Terror', Space and Polity, 2:1 (2008), pp. 63-79.

Walters, W., 'Foucault and Frontiers: Notes on the Birth of the Humanitarian Border', in U. Bröckling, S. Krasmann and T. Lemke (eds), Governmentality: Current Issues and Future Challenges (New York: Routledge, 2011), pp 138-64.

Weber, L. and S. Pickering, Globalization and Borders: Death at the Global Frontier (Basingstoke: Palgrave Macmillan, 2011). 
Westcott, L., 'Refugees vs. Migrants: What's the Right Term to Use', Newsweek (11 September 2015), www.newsweek.com/refugee-vs-migrants-whats-right-term-use-37 222. Accessed 15 July 2017.

Zampaglione, A., " "Thanks for 60 years of Italy-UN partnership”, said Ban Ki-moon in Rome', 15 October 2015, www.onuitalia.com/eng/2015/10/15/thanks-for-60-years-of-italy-unpartnership-said-ban-ki-moonin-rome/. Accessed 25 lune2016. 


\title{
The role of aid agencies in the media portrayal of children in Za'atari refugee camp
}

\author{
Toby Fricker
}

When the Syrian conflict escalated in early 2012, there was still little sense that this would result in what is now described as the worlds biggest humanitarian crisis of our time. ${ }^{1}$ But by mid-2012, thousands of Syrians, half of whom were children, started $\mathrm{fl}$ eing their country for safety across borders, including to their southern neighbour Jordan. ${ }^{2}$ To cope with the rapid infl $\mathrm{x}$ of people, the Jordanian government opened Zaatari refugee camp in late July 2012, with support from the Jordan Hashemite Charity Organisation, United Nations agencies and other partners. ${ }^{3}$ In the harsh conditions of Jordan's northern desert, Zảatari rapidly became a massive aid operation and at the same time the media face of not only the refugee crisis in Jordan but aross the region.

What was apparent, from the early days of the camp, was the large numbers of children and young people fl eing Syria, with more than half of the Zaatari population under eighteen years of age. ${ }^{4}$ For visitors, statistics were unnecessary; there were simply children everywhere. The majority came from the southern Syrian province of Dar'a, where the conflict fi st erupted. It was from here that children became central to the narrative of the Syrian conflict, when in March 2011 a group of teenagers painted a phrase on theirschool walls in Dar'a town calling for the fall of the government. ${ }^{5}$ Theboys were reportedly arrested, beaten and tortured in prison. ${ }^{6}$ After Friday prayers on 18 March 2011, a protest march took place during whichfi e demonstrators were killed and the conflict in Syria was born.?

The hundreds of refugees crossing to Jordan daily turned to thousands by late 2012 and Zaatari grew rapidly in size. Aid agencies foundthemselves in a race against time to provide shelter, food, schooling and other services for those arriving. ${ }^{8}$ At the same time, joumalists and TV crews from across the world became part of the Zaatari landscape. The camp was a major news story and by August 2013, the 120,000 Syrians were living within a melting pot of aid workers, joumalists, visiting politicians and celebrities. 9 Th ough extensive experience of working with media in Za'atari, news reports from international English-language media and academicliterature, this chapter looks at the portrayal of children in media coverage of the camp. 
By analysing how reporting on children's issues evolved over a three-year period and the role of aid agencies in the newsgathering process, this piece of work argues that the relationship between humanitarian organisations and journalists can be mutually benefi ial and result in reporting with deeper context and nuance, whilst better protecting children along the way.

Th re are well-documented concerns about the focus on media work by aid agencies and their close relationship with joumalists. Simon Cottle and David Nolan claim that, 'Th se developments imperil the very ethics and project of global humanitarianism that aid agencies historically have done so much to promote. ${ }^{10}$ Glenda Cooper also questions the editorial integrity of journalists working with aid agencies: 'While journalists - if sometimes imperfectly - work on the principle of impartiality, the aid agency is usually there to get a message across: to raise money to raise awareness, to change a situation. ${ }^{11}$ Despite this, the collaboration between aid agencies and journalists may serve each other's interests but also produces more informative, accurate and engaging media content for the reader, viewer or listener. With increasing debate and discussion about the rising role of fake news and in a post-truth pditical environment this could be moe important than ever. ${ }^{12}$

Th s outlook is most likely too positive for some but the case is put forward by focusing on the period from the opening of Zaatari camp in late July 2012 until July 2015 , during which two phases of media coverage are identifi $\mathrm{d}$. Thefi st could be termed a more hard news approach that mirrors the acute emergency phase of aid operations in Za'atari, where children are framed in what could be perceived as a more negative manner. For example, children who vow for revenge in the fight back in Syria and others who play a role in the reported lawlessness of the camp's earlier days. While the second phase of media coverage, from early 2014 until mid2015 , refl cts a more features led approach with deeper context and nuance to articles, presenting children as more actively and positively involved in camplife. Th s includes articles about children desperate to continue their education and others who are improving their living conditions by designing small gardens. Reporting that refl cts an ongoing childhood and aspirations for the future, despite everything children have been through.

\section{A newsworthy venture}

After opening, Zaatari rapidly became a major global news story, with signific nt media coverage from the camp focusing on issues related to children and young people. Given that this was, as Sean Healy and Sandrine Tiller note, the most easily accessible camp in the highest profile conflict in the world, it may not be surprising. ${ }^{13}$ But it is important to consider the news values for foreign media coverage, such as those cited by Johan Galtung and Mari Holmboe Ruge, to provide some insight in to the media's decision-making process for coverage from Za'atari. ${ }^{14} \mathrm{Th}$ s helps us to better understand how and why reporting evolved over time and what role aid 
agencies may have had in influ ncing the discourse used. Galtung and Ruge focus on the process that leads to a story being produced, 'a chain that could have seven or eight steps in it or be much shorter if the newspaper has a correspondent. ${ }^{15}$ Whether there is a reporter on the ground close to the location of the 'event' is an important consideration. For at the top end of the chain, where editorial decisions are made in capitals far from the news, exacting influ nce can be more challenging. When a correspondent is present, there are greater opportunities for aid agencies to play a more direct role. In both cases, personal relationships are critical, for journalists not only bring with them the interests of their organisation but also their own experiences in society, which are, as Rukhsana Aslam notes, ingrained in their minds from childhood. Thereporter, as an individual interprets the events they cover and forms the 'fi st draft of history', which is why the relationship between aid workers and joumalists is so impoitant. ${ }^{16}$

Whether a reporter gets to the relevant location in the fi st place relies on a number of factors. Economicissues, distance, safety and media accreditation all play their part. The economicinterests of media outlets are often at the forefront and with foreign news budgets shrinking sustained coverage of humanitarian crises is a challenge. ${ }^{17}$ As John Simpson notes, 'Most newspapers have largely sacked their foreign correspondents, relying instead on one or two staff members, one in, say, the United States and the other perhaps in the Middle East. ${ }^{18}$ Despite this, conflicts, natural disasters and health emergencies are more likely to fit the required narrative of big bangs and negative news to justify the cost of covering the story. ${ }^{19}$ When there is a major 'event' within these crises, as opposed to an ongoing process, this is also more likely to be reported..$^{20}$ Add in some elite people, or celebrities, and the probability that it will become news rises further. ${ }^{21}$

In the case of Zaatari, access was not such a pertinent issue. Travelling to Jordan is easy, safe and relatively inexpensive, while at just over an hour from the capital, Amman, the camp is an easy day trip, with a full range of accommodation options on return. Once in Jordan, acquiring media permits to enter the camp was initially straightforward and required not much more than an email and printed acceptance. When this process became more complicated in late 2013 , there was a shift in the working relationship between aid agencies and journalists. But there were also a number of hyers of access, as the jumalist Rana F. Sweis noted:

In order for me to see some of the refugees in the centers and other spaces, I had to organize this through the respective aid agencies. So in some ways the aid agencies were facilitators and in other ways they were the experts on the issues and provided me with information I often needed. ${ }^{22}$

To enter the schools, health clinics and youth centres in the camp, as in any town, you needed permission and aid agencies were primarily managing these services. Th re was at the least a forced relationship though joumalists were not always 
interested in activities at the centres. In phase one of coverage, Syrian refugees were vital sources for reporters to get fi st-hand information about the situation inside Syria. Journalists were primarily focused on talking with families who had just fl d theircountry. TheSyrian refugee population in Lebanon was very scattered, with no official camps, and those in Turkey and Iraq harder logistically and more expensive to reach. From its outset, the war in Syria has been extremely dangerous to cover. In 2012 , Reporters withoutBorders called Syria a 'Cemetery for News Providers'. In the following years, the conflict became even more complicated and dangerous to cover. Joumalists would often request to interview people who had just arrived from Syria, those who could provide stories from across the border just 15 kilometres away. Ths changed when Zaatari was declared full by the camp management and Syrians arriving in Jordan were sheltered in Azraq camp that opened at the end of April $2014^{23} \mathrm{Azraq}$, from its outset, had much stricter regulations for journalists and interviewing families was a much mor controlled process.

Events inside Zaatari also met the news values in that, 'The more negative the event in its consequences, the more probable that it will become a news item. ${ }^{24}$ Incidents of unrest, violence and sexual harassment all fed the media agenda. It was an abnormal environment: a camp that grew out of the desert within months and by March 2013 was being referred to as Jordan's fifthlargest town. ${ }^{25}$ Regular high profile visitors and elites, from actress Angelina Jolie to the US Secretary of State, John Kerry, also contributed to the regular media coverage, despite the fact that only 15 per cent of the Syrian refugee population lived in Zaatari. It was very challenging to convince journalists to cover stories outside of the camp. Th re were concerted effo ts by a number of aid agencies to do this but with few results, particularlyduring the earlier days of thecamp.

\section{The Za'atari child}

Thefi st phase of media coverage includes the period from the opening of the camp until early 2014 During this timeframe, Za'atari became synonymous through the media, for being a lawless place where children ran riot and harboured thoughts of revenge on their return to Syria. 'We are going to kill them with our knives, just like they killed us', eleven-year-old Ibtisam is cited as saying in one New York Times article titled, 'Syrian Children Off $r$ Glimpse of a Future of Reprisals. ${ }^{26}$ Th s early media discourse portrays children in a more aggressive and threatening manner, young people who were not only responsible for playing a role in the instability of the camp but who were looking to fuel the fight back home. 'Young Refugees to Haunt MidEast for Years', reported Mark MacKinnonforCanada's Globe and Mail. ${ }^{27}$ While Catherine Philp's UK Times story led with, 'Children are Groomed for War in Huge Refugee Camp. ${ }^{28}$

Theattention-grabbing headlines may notbe surprising but withinthe main body of the articles, the portrayal of children often refl cts the pre-existing frames that 
Jaap Van Ginneken notes as being critical to media producers and consumers in their understanding of the world ${ }^{29}$ Philp writes about meeting a boy playing computer games on the camp's main street. 'Counter Strike, has become the most populous diversion for the thousands of young, restless boys of Zaatari refugee camp. "It teaches us how to fight jihad"', nineyear-old Mohammed is quoted as saying. MacKinnon a\$o uses the computer game analogy:

Counterstrike, which pits terrorists against counterterrorists. Players watch over the barrel of a virtual assault rifle as bullets slash through virtual enemies. Also, because the computers are connected, kids can divide into teams and recreate 'Regime against Rebels. ${ }^{31}$

Thearticle goes on to explain how another child is waiting for his chance to join the jihad, following a question to the boy about how the war is going. The link in the articles between violent computer games and the conflict that the children $\mathrm{fl} d$ is in some ways pertinent. It highlights an example of what Galtung andRuge call 'cultural proximity' that helps to engage an audience. 'That is, the event-scanner [audience] will pay particular attention to the familiar, to the culturally similar, and the culturally distant will be passed by more easily and not be noticed. ${ }^{32}$ Parents geographically removed from the Syrian crisis can identify with this image being played out in their own homes. But while a European or North American child plays the game for fun, the children in Zaatari prepare themselves for jihad, framing Syrian children within the global terrorism narrative. As David Altheide notes, terrorism has become a domimant frame surrounding many cultural and institutional narratives, which produces a code for the 'fear of the other. ${ }^{33}$ With media texts a part of our world, this positioning may not be surprising, 'for these texts and images are social phenomena and often part of the debate about society going on in the world. ${ }^{34}$ The language used influ nces how we talk or thinkabouta subject and as SuzanneFranks has highlighted, public awareness about humanitarian disasters is primarily defin $\mathrm{d}$ by the media, which is why the discourse used in representing Syrian children is so important. ${ }^{35}$ When Philp's story was read by a Jordanian aid worker in the camp the response was, 'Th s presents a twisted version of the reality in Za'atari. ${ }^{36} \mathrm{He}$ was particularly surprised by the jihad reference stating that it was quite normal for children to play the game for fun, as opposed to the article's more sinister insinuation. Th s framing is maybe predictable, as Jean Seaton notes, 'stories news-makers construct are often shaped by a limited range of established narratives into which diverse and real events are fi ed. ${ }^{37}$ In some articles, quotes from aid workers were used to help explain why children behaved in a more aggressive manner. 'Such profound stress can be mind-altering, especially for young brains, which switch off simply to survive ... Theycan't determinerisk anymore and when they get angry they have no ability to control these impulses', a child protection officer is quoted as saying. ${ }^{38}$ While this provides valuable context, it could be argued that the overall framing of the article 
around children's determination to exact revenge already presented children as complicit in the violence. On some occasions, the concerns raised by humanitarian organisations played in to this narrative. For example, one aid worker is quoted as saying, 'I'm afraid of the lids here. ${ }^{\text {' }}$

The Syrian popultion crossing in to Jordan presented a diff rent image of children aff cted by humanitarian crises. The 'Live Aid Legacy' visual, of 'starving children with flies around their eyes', wouldn't fit the narrative, nor was the reality, for Syrian children in Zaatari. ${ }^{40}$ They were not poverty-stricken or malnourished but were from the working-and middle-class communities of towns and villages across Syria. They were living a childhood like any other children, most were attending school in a country that had a 97 per cent enrolment rate before the conflict. ${ }^{41}$ But they were now deeply traumatised from their experiences of conflict and displacement. Th $\mathrm{s}$ is an important consideration when it comes to the aid agency response and media discourse from Zaatari. Education and child protection issues came to the forefront, two sectors that are often not prioritised, particularly when it comes to funding. For example, prior to the Syrian crisis educationin emergencies received on average just 2 per cent of humanitarian aid funds. ${ }^{42}$ In this new environment, aid agencies focused on raising awareness about the education and child protection issues aff cting Syrian children. The 'No Lost Generation' initiative was one example of this work ${ }^{43}$ The campaign included multiple partners and was designed to highlight the critical needs of getting Syrian children back to school, as well as 'to help them heal from the horrors of war and displacement and to better engage young people in the issues aff cting them. ${ }^{34}$ The initiative was to act as an early warning message about the long-term impact of a whole generation of children growing up through conflict, at the same time there was a clear fundraising goal to support the two sectors of often underfunded humanitarian assistance. Thelanguage used in the 'No Lost Generation' initiative is one of urgency. 'An entire generation of Syrian children and youth are living through conflict and displacement. Theyare on the verge of being a lost generation. ${ }^{45}$ Thewarnings balanced with a sense of hope, 'But against all odds, children and youthare not giving up on theirdreams and aspirations', and a call for support, 'We all must do more to provide them with opportunities to heal, to learn and to thrive again' Thediscourse was used in varying degrees across a number of media reports. 'A Lost Generation: Young Syrian Refugees Struggle to Survive', led a New York Times article by Jodi Rudoren, the story refl cting some of the key concerns raised by aid gencies about the fitures of Syrian children.

Th se children, the next lost generation, make up a particularly troubling category of collateral damage from Syria's chaotic conflict, which has left 70,000 people dead. Th re is Ahmad Ojan, fourteen, who wanted to be a teacher, but now spends his days peddling tea in Jordan's sprawling Za'atari refugee camp. And there is Marwa Hutaba, fifteen, who still hopes to be a pharmacist, but is increasingly worried she might be married off to a wealthy foreigner - like the fourteen-year-old who disappeared from school after 'getting engaged one day and married the nex'.46 
Freelance joumalist Stephanie Parker, who reported for the New York Times, stated that, 'I'm very aware of the No Lost Generation initiative. In the series of stories that I wrote revolving around refugees I used the spirit of the program and the importance of it without directly referencing the campaign. ${ }^{37}$ While Parker knew about the initiative, many other journalists did not but the essence of a 'Lost Generation' of Syrian children was picked up in many articles. Theinvolvement of multiple aid agencies in the initiative, at a headquarters, regional and country level, helped create a commondiscourse when talking about education and child protection issues with the media. 'Inside a Refugee Camp with Syria's "Lost Generation"' led a NBC News story. ${ }^{48}$ While the headline implied that it was too late for the children, thearticle refl cted the essence of the issue. 'Gassem and Jalal have not stopped thinking about the future. Even though he is too intimidated to attend school in the crowded camp full of strangers, Gassem dreams of one day becoming a doctor. The No Lost Generation initiative played a role in framing the education and child protection issues in Zaatari within the media. Th $\mathrm{s}$ is not to say that the news selection process was necessarily influ nced, for as Silvio Waisboard notes, there are so many determining factors along the media chain. ${ }^{49}$ But the commondiscourse helped aid agencies to present one voice around the elevant issues when working with media.

\section{The shifting media narrative and evolving conditions on the ground}

As timeprogressed, it was clear that the conflict in Syria was not going to be resolved soon. Life in Za'atari became more routine and stable, with an increasing sense of semi-permanence in the camp. By early 2014, a shift in the ature of media coverage can be identifi $\mathrm{d}$, with articles that looked more at the resolve of children and their active involvement incamplife, as opposed to direct associationwith the conflictback home or violence within Zaatari itself. Thehard news giving way to an increasingly features-led approach, for example 'The Secret Gardens of Syria's Refugee Camps' in which children and their parents are involved in a gardening project organised by the NGO, Save the Children, to 'start building just a bit of hope and happiness. ${ }^{50} \mathrm{Or}$ the children who enrol in taekwondoclasses and are featured in a documentary and Buzzfeed article, 'a surprisingly uplifting story in the midst of all this tragedy. ${ }^{51}$ The

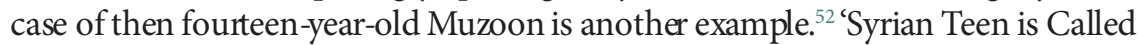
"the Malala of Za'atari", ran a CNN edition headline. ${ }^{53}$ 'We can help and improve our nation with education', Muzoon is quoted as saying. While there is recognition of the desperate situation that many Syrian children face, the story focuses on the childhooddreams of oneyoung girl. 'Days go by, and an end to the Syrian crisis does not seem near, but [Muzoon], who dreams of someday becoming a journalist, is already thinking of better days for her country's future', reports Alvarado. Thework behind this story provides an interesting example of the intersection between aid agencies and journalists. In the summer of 2013, Muzoon was part of a team of girls who went from hometo hometrying to convince children and theirparents to enrol 
them forschool. ${ }^{54} \mathrm{An}$ articulate and inspiring girl, Muzoon played a key role in advocating for children to continue their education in the camp. For media she was an obvious choice and Muzoon spoke to a number of news outlets but it was following the visit of global education advocate, Malala Yousafzai, with whom she spent a day in the camp in February 2014that journalists would specifica ly ask to talk with her (see figure 8.1). Thefocus on Muzoon by the media meant she played a critical role in changing the discourse around young people's issues. But the relationship with the media had to be carefully managed by aid agencies. Resentment withinthe community, a perception of preferential treatment and a lack of opportunity for other girls were some of the sisues that had to be addressed.

Another example of the shift in media portrayal of children is an audio photo essay, 'Th ough Teenagers' Eyes: UniqueSnapshotsof Syrian Refugee Life, featured by $\mathrm{BBC}$ Online. ${ }^{55}$ The content focused on a project run by the charity, Save the Children, that included the work of Syrian teenagers in photographing their lives in Zaatari. The BBC on this occasion published prepackaged content. 'I want to be a famous photojournalist and travel the world, says Khaled. ${ }^{56}$ 'The children struck me as being very optimistic for their situation', adds photographer Michael Christopher Brown, who worked with the children. The involvement of an internationally renowned photographer may well have helped in the placement but the

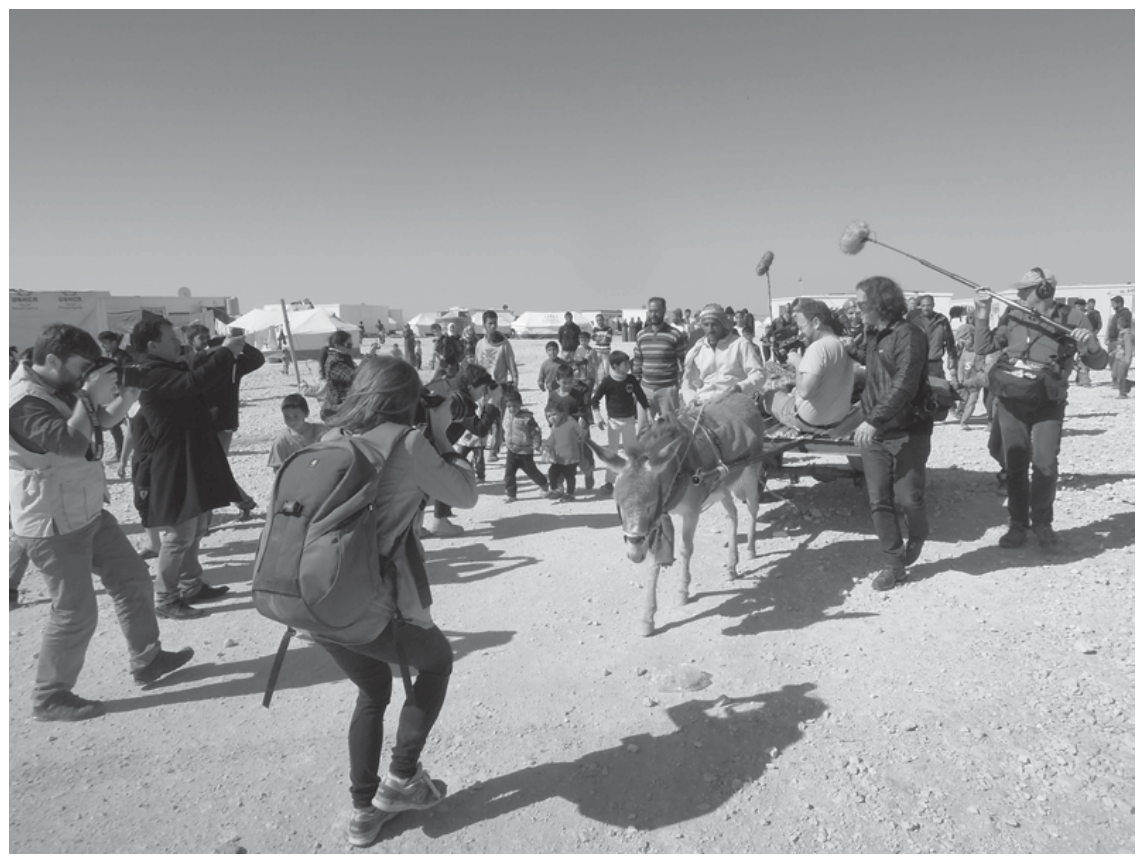

Figure 8.1 Malala Yousafzai at the camp 
voices presented here are a far cry from the sentiment of the children who expressed their desire for jihad in the earlier articles reviewed. While it can be expected that content produced by an aid agency about one of its projects would focus more on the positives, it was still exposed to the news selection process, as part of the BBC's coverage.

It is important at this point to revisit the issue of access, as a factor in the evolving media coverage of children's issues in Za'atari. As mentioned earlier, media permits to access the camp were granted relatively easily during the fi st phase of reporting and journalists were freer to come and go. The conditions on the ground meant that reporters could take more time, or the amount allocated by their organisation, to identify their stories and the children to interview. But this changed in late 2013 and the earlier reporting, perceived as more sensationalist, was a contributing factor. The process for acquining media permits for Za'atari became more stringent and, when granted access, journalists were only allowed two days to report from the camp before having to apply again. Th s played a role in changing the working relationship between journalists and aid agencies on the ground. The portrayal of children in Za'atari during phase one of coverage, from potential jihadists to the camp's number one troublemakers, had a direct impact on families living there. As Linda Polman highlights, 'Most refugee camps have TVs that can pick up CNN, so refugees see how "we" portray victims. ${ }^{57}$ While Za'atari residents were not watching CNN, they were viewing other satellite channels in 2013. Th re was also access to the internet through phones and many residents were in regular contact with relatives both inside Syria and further afi ld. Thehigh profile presence of media in the camp from the outset had been tolerated by most people in the camp. While some were not willing to talk with joumalists, or be photographed, for fear of repercussions on family members back home and because they were expecting to return to Syria, others wanted to tell the world theirstories in the hope of more outsidesupport. But as more reporters came to Za'atari and the situationinsideSyria got worse, residents became less tolerant of what they perceived as a negative portrayal of Syrians in the camp, including children. Coverage of the so-called pleasure marriage story became particularly problematic.

The story of pleasure marriages was based on Syrian women and girls who were being married off to older men, the majority of whom were reported to have come from Gulf countries. Th se marriages would then be annulled within a couple of months or weeks, as the men left, so in eff ct a form of prostitution. 'In a Jordan Camp, Outsiders Seek Syrian Brides', reported the Washington Post. ${ }^{58}$ While the Daily Telegraph highlighted how Syrian girls were being sold into 'forced marriages. ${ }^{59}$ "The "dowry", which in Muslim society is traditionally paid by the groom as a guarantee of the bride's security, has become a payment for sex. And the "marriage", is an affairthat lasts only a few days or even hours', the article explained. Th s pleasure marriage narrative was predominant in the fi st phase of media coverage and was a very sensitive subject in the camp. An Agence France Presse article featured a father 
who explained that he had no choice but to marry offhis teenage daughter to a fortyyear-old Saudi man. ${ }^{60}$ The report also highlighted how a group of activists in the camp were trying to stop the marriages. " "We launched a revolution to win back our dignity," Naimisaid. "We are not going to surrender it fora dowry". Th se emotions would soon have an impact on the work of journalists in the camp. Aid agencies spoke about their concerns of the reported pleasure marriage practice but had few hard facts to add to the story. 'We have seen no evidence of prostitution in the camp, but we have heard rumors of it', the head of the United Nations Refugee Agency (UNHCR) in Jordan, Andrew Harper, was cited as saying in an Associated Press article. ${ }^{61}$ 'Given the vulnerability of women, the camp's growing popultion and the lack of resources, I'm not surprised that some may opt for such actions', he added. In a number of quotes on the issue, Harper framed the problem around a need for more fi ancial support for aid agencies, so that families could be better assisted and as a result were not driven to such desperate measures. When journalists reported on the story, they would often source the aff cted girls in the camp themselves. One of the fi st locations to visit was the wedding dress shop on Zaatari's market street. A steady stream of reporters went to take photographs and conduct interviews. But there was growing frustration amongst residents about the way media were portraying Syrian girls. When a TV crew from Al-Arabiya arrived on the camp's market road in October 2013, rumous spread that they were focusing on a pleasure marriage story, and they were subsequently attacked and had to be escorted to safety by Jordanian police. ${ }^{62}$

In late 2013 , the Jordanian authorities reduced the permitted reporting time in Zaatari to two days per visit and journalists were required to leave the camp by 3 p.m. each day. With less time, this meant an increased reliance on aid agencies to access stories and families in the camp. But this development also came at a time when aid agencies had to be more careful than ever when accompanying journalists around the camp. It could be problematic to be associated with media who were perceived to be contributing to the negative image of Syrian girls and residents of the camp as a whole, or media outlets whose governments took a particular political stance. For example, some families in Zaatari would not talk with Chinese or Russian media, given their countries' backing of the Syrian government. While aid workers were building stronger relationships with people in Za'atari and given their long-term presence on the ground, they did not want to jeopardise this. As Kimberly Abbot notes, 'Thelives of staff members, especially nationals, can be endangered, if reporters they accompany are associated with the "wrong side" or are reporting in what is seen as a more exploitative manner. ${ }^{63}$ But media embedding with aid agencies that would normally be more prominent in the fi st acute phase of an emergency, became more common and critical, as reporters were time-restricted. Aid agencies could provide journalists with quickaccess to stories and an overview of the problems and issues. Working with journalists in covering sensitive issues, such as the pleasure marriage story, was 
important in other ways. Despite not being able to add specific facts or information about the pleasure marriage phenomenon, supporting reporters who would cover the story anyhow could help to better protect and support children and families interviewed. A specifichandbook for joumalists was produced with guidance on 'Reporting on Gender-Based Violence in the Syrian Crisis', which highlights how 'child marriage is not always perceived as a "real" form of gender-based violence, so journalists can be unscrupulousin sharing details, including pictures of young brides. ${ }^{64}$ By being involved in the newsgathering process, child protection workers can help to create a more protective environment. For example, framing questions in a more sensitive way and through providing follow-up support to the child after their interview. Freelance reporter, Stephanie Parker, noted that:

Agencies did have a big impact on how I reported because organisations like UNICEF acted as a gatekeeper, protector, or armed guard of the children if you will. Th s protection type attitude made me feel comfortable and at ease about how the children were being treated and grateful that they wanted to speak to me about theirfamily life and circumstance. ${ }^{65}$

\section{From pleasure to early marriage}

The coverage of the so-called pleasure and early marriage issue provides a deeper insight into the evolving narrative between phase one and two of reporting from the camp. Thepleasure marriage story became newsworthy in the earlier days ofZa'atari, as the issue fi ed well into the news frame. It was an event, whereby a girlis married and then the so-called marriage is relatively quicky annulled. Th s is important, as Jake Lynchand Johan Galtung note, the rhythmof news is punctual based on events not processes that take more time to evolve and reveal where they are headed. ${ }^{66}$ The pleasure marriage story also demands attention of readers because it 'crashes through routine order. ${ }^{67}$ Young girls from a religious conservative background are sold off to rich men from the Gulf. For international readers, this is a shocking consequence of the refugee crisis. Themedia spotlight, in the pursuit of readers, ratings and revenue, is, as Cottle and Nolan note, drawn selectively to images of distress rather than issues of structural disadvantage, in which early marriage would more clearly fit ${ }^{68}$ The portrayal of Syrian girls, as being exploited through the pleasure marriage narrative, was a factor that changed the working conditions for journalists on the ground and, as highlighted, potentially played a role in complicating media access to Za'atari. By early 2014, media coverage of the issue evolved to look in more depth at the practice of early marriage amongst the Syrian refugee population. While both pleasure and early marriage are classifi $d$ as gender-based violence and detrimental to the futures and health of the girls involved, the nuances between the two are important. ${ }^{69}$ Theyare fundamentally diff rent issues that require diff rent types of responses. As Mukkaram Odeh notes: 
The crisis complicated this problem [early marriage] even more because of the lack of safety and stability. It increased fears regarding economic challenges and harassment, and many refugee families believe that their daughters will be safer if they are married. ${ }^{70}$

While there were fi ancial considerations, there was a sense amongst somefamilies that it was in the best interest of theirgirls to marry younger, and in the majority of cases to men within their own community. ${ }^{71}$ Thepleasure marriage story, however, was driven by a narrative of exploitation. When new statistics on the extent of early marriage amongst Syrian girls were verifi d in mid-2014it provided an opportunity for aid agencies to present a more in-depth picture. Therelease of two new reports by UNICEF and Save the Children were timed to coincide with the 2014 'Girl Summit, hosted by the UKgovernment andUNICEF inLondon Thegathering aimed to push for'concrete commitments to end child, earlyandforced marriage and femalegenital mutilation for girls everywhere.' ${ }^{72}$ The UNICEF report, 'A Study on Early Marriage in Jordan, 2014, showed the rate of child marriages amongst Syrian refugees in the country increased from 18 per cent of total marriages in 2012, to 32 per cent in 2014, while 'Too Young to Wed' focused more on case studies and stories of girls who had married early. ${ }^{73}$ Thenew statistics and information in the reports, including quotes from aff cted girls, were picked up by a range of media. The Guardian highlighted the increasing numbers of girls marrying early and the subsequent impact, 'Child marriage among Syrian refugees in Jordan has more than doubled since the start of the conflict, leaving girls vulnerable to health problems, domestic abuse and poverty, the UN has warned'. Thearticle went on to identify the factors responsible for children marrying early, as well as further depth into the long-term impact. 'They[girls] also have more limited economic opportunities due to loss of schooling and can get trapped in a vicious cycle of poverty', the UNICEF Jordan Representative was quoted as saying. ${ }^{74}$ 'Child marriages double among Syria refugees in Jordan', reported Agence France Presse, while Buzzfeed used photos of drawings produced by Syrian girls in Za'atari to raise awareness about the dangers of child marriage. ${ }^{75}$ The article presented a more creative and visual way to tell the story. The communications products to accompany the new reports were produced to target media outlets and confom to the known dispositions of news organisations. ${ }^{76}$ A process that Natalie Fenton refers to as " "news cloning" that mimics, or indeed matches, the requirements of mainstream news agendas', but does not mean that aid agencies 'have managed to change news agendas and challenge normative conceptions of news criteria. ${ }^{77}$ Cottle and Nolan believe that by working in this way aid agencies 'practically detract from their principal remit of humanitarian provision and symbolically fragment the historically founded ethic of universal humanitarianism. ${ }^{78}$ However, in the case of the early marriage reports and related communications products, it renewed focus and presented an opportunity to advocate for more support to tackle the issue, whilst providing additional context and reporting in a more dignifi d way for the girls and families aff cted. Ths is particularly important, as media attention of early marriage 
had mixed consequences. 'Syrian girls and their families reported feeling that the media contributed to a negative perception of Syrian women and girls, and sometimes reacted by increasing isolation and control over young women. ${ }^{79}$

Th re was a spike in coverage of the early marriage story around the 'GirlSummit and the reportsalso led to follow-up coverage fromjournalists in subsequent months, forexample an articleby the New York Times, 'In Jordan, Ever Younger Syrian Brides', that looked in depth at the issue. 'The girl, Rahaf Yousef, is 13. Speaking wistfully of her days at school, she declared herself throughoutthe day to be "indiff rent" to the marriage she says will keep her from fin shing her education. But no one seemed to be listening.' Thearticle went on to includesome of the ongoing effo ts to tackle the rising trend:

Aid agencies and organizations are alarmed enough by the increase in early marriages that theyhave been conducting awareness campaigns. 'You'll be surprised at the lack of knowledge among the community about the devastating health consequences of early marriage,' saidFasel Shammout a psychologist who has donetraining for the refugees. 'By the time they each us, they ae in a dre strait - legally, mentally, physically.80

While the pleasure marriage story was important to cover and may have been a more compelling, simplistic and attention-grabbing narrative, as with the children awaiting their clance to join the jhad, it was far from the fill picture.

\section{Conclusion}

Theinternational media narrative covering children in Zaatari camp evolved as time progressed, from one where Syrian children were portrayed as more aggressive and threatening, to a representation that focused more on their resolve and aspirations. Thepotential influ nce of aid agencies on this discourse is one of a number of factors to consider, given that many mechanisms intervene to shape the news. ${ }^{81}$ The shift in the discourse refl cted life in the camp, as the days became more stable and routine, while the aid operation evolved from an acute emergency operation into a more systematic response. But the loss of trust between the Zaatari population and journalists, as a result of what was perceived as negative media coverage, particularly around the pleasure marriage issue, led to tougher working conditions for reporters. Th re were direct attacks against joumalists and access became harder when the media accreditation process was made more stringent, including a reduction in the time allowed to report from the camp. Withless fle ibility, there was more of a reliance on aidagencies to source people and stories and as a result a greater role in the newsgathering process.

The Syrian refugee crisis presented a new image of children and young people $\mathrm{fl}$ eing war. Working- and middle-class populations forced to $\mathrm{fl}$ e their houses and apartments for the relative safety of what becamethelargest refugee campacross the region. While living conditions were tough, it was the loss of education and ongoing psychological recovery from exposure to conflict and displacement that would have 
the most immediate and mid- to long-term impact on children. Initiatives such as 'No Lost Generation' were designed to raise awareness and more funds for these traditionally underfunded sectors of humanitarian work. The discourse used in the campaign was meant to appeal to media and to present the challenges but also the hope and aspirations of Syrian children aff cted. The nuance of the language arguably in some cases played in to the more negative outlook for Syrian children but the essence of supporting a generation of children to regain their childhood helped to frame the education and protection issues at the forefront of the response. As time went on, media articles in phase two of coverage had an increasingly features-led approach and looked more at children's involvement in camplife and what it meant for their lives. Th s was in contrast to earlier reporting, where Syrian children were framed within marratives that emerged as part of the $\mathbf{0}$-called 'War on Terror.82

Ths chapter argues that aid agencies can help to provide the extra context required for more sophisticated coverage of issues aff cting children during humanitarian crises. Th s is seen more clearly in the later media reports from Zaatari, as the evolving pleasure to early marriage story highlights. As Abbott notes, NGO and media partnershipsare a reality and can lead to stronger foreign news reporting that better serves audiences in our interconnected world. ${ }^{83}$ In today's society, where the fear of the other is often refl cted in media narratives, I would argue that aid agencies have an even more critical role to play, or even a moral obligation, to amplify the voices of children aff cted, so that they are not drowned out. ${ }^{84}$ The media presents an important opportunity to advocate for the rights of the children aff cted, to contribute to public education and to support fundraising effo ts. While aid agencies have clear goals and aims, the information provided shouldadd to and be a natural part of the story. When aid workers are part of the news process they can also help to better protect children and encourage more ethical reporting on sensitive and traumatic subjects. The media portrayal of Syrian children in Za'atari is so critical because the language used provides us with not just a mode of interaction but also with a capacity for representation. ${ }^{85}$ As the Syrian refugee crisis subsequently spread to Europe, it was in turn followed by a narrative of fear and negativity that often failed to take into account the impact of the situation on children. Theeff cts of this discourse - similar to those prominent in the early days of the Za'atari camp - are now being felt across theworld.

\section{Notes}

1 BBC, 'Syria Conflict: "Biggest humanitarian crisis since 1945” - Gordon Brown' (4 February 2016), www.bbc.com/news/ world-middle-east-35489063. Accessed 7 June 2016.

2 UNICEF, Shattered Lives: Challenges and Priorities for Syrian Children and Women in Jordan ( Jordan: UNICEF, 2013), www.unicef.org/mena/MENA_Shattered_Lives_Junell.pdf. Accessed 9 May 2016.

3 S. Wilkes, 'Jordan Opens New Camp for Syrian Refugees Amid Funding Gaps', UNHCR (30 July 2012), http:// bit.ly/2b7nnqT. Accessed 21 May 2016. 
4 UNICEF, Shattered Lives.

5 F. Keane, 'Syria: TheBoys Who Helped Sparka Revolution', BBC (13 April 2013), http:// bbc. in/2bGPPwq. Accessed 25 My 2016.

6 J. Bowen, The Arab Uprisings: The People Want the Fall of the Regime (London: Simon \& Schuster, 2012).

7 Bowen, The Arab Uprisings.

8 The reference to aid agencies in this chapter refers to United Nations agencies and local and international non governmental organisations (NGOs) working in Zảatari refugee camp.

9 UNICEF, Shattered Lives.

10 S. Cottle and D. Nolan, 'Global Humanitarianism and the Changing Aid-Media Field', Journalism Studies, 8:6 (2007), p. 862.

11 G. Cooper, 'When Lines between NGO and News Organization Blur', NiemanLab (21 December 2009), http:// bit.ly/1DpvRKL. Accessed 11 December 2015.

12 'Post-TruthPolitics: Art of the Lie,'Economist (10 September 2016), http:// econ.st/ 2bVXLHU. Accessed 20 October 2016.

13 S. Healy and S. Tiller, 'A Review of the Humanitarian Response to the Syrian Refugee Crisis in Jordan 2012-13', MSF (October 2013), www.msf.org.uk/ sites/ uk/files/ jordan_case_study_ fi al_external_0.pdf. Accessed 25 My 2016.

14 J. Galtung and M. H. Ruge, 'The Structure of Foreign News', Journal of Peace Research, 2:1 (1965), pp 64-91.

15 Galtung and Ruge, 'The tructure of Foreign News', p. 65.

16 R. Aslam, 'Peace Journalism: A Paradigm Shift in Traditional Media Approach', Pacific Journalism Review, 17:1 (May 2011), pp. 119-39, https:// pjreview.aut.ac.nz/articles/peacejoumalism-paradigm-shift-traditional-media-approach-476. Accessed 1 My 2016.

17 J. Curran, Media and Power (London and New York: Routledge, 2002).

18 J. Simpson, We Chose to Speak of War and Strife: The World of the Foreign Correspondent (London: Bloomsbury, 2016).

19 J. Lynch and A. McGoldrick, Peace Journalism (Stroud: Hawthom Press, 2005).

20 J. Lynch and J. Galtung, Reporting Conflict: New Directions in Peace Journalism (Brisbane: University of Queensland Press, 2010).

21 Galtung and Ruge, 'The tructure of Foreign News'.

22 R. Sweis, Interview with the author, 15 June 2016.

23 E. Oddone, 'Azraq Refugee Camp Officially Opened', The Jordan Times (30 April 2014), http:// bit.ly/28T4a6F. Accessed 10 May 2016.

24 Galtung and Ruge, 'The tructure of Foreign News'.

25 N. Bulos, 'Jordan Feeling the Strain of Syrian Refugee Crisis', Los Angeles Times (22 March 2013), http:// lat.ms/ 2hftvid. Accessed 18 June 2016.

26 D. Kirlpatrick, 'Syrian Children Off $\mathrm{r}$ a Glimpse of a Future of Reprisals', New York Times (3 September 2012), http:// nyti.ms/2h8HBBg. Accessed 2 April 2016.

27 M. MacKinnon,'Why Young Syrian Refugees will Haunt the Mideast for Decades to Come', The Globe and Mail (14 September 2013), http:// bit.ly/1k8a5Z2Accessed B May 2016.

28 C. Philp, 'Children are Groomed for War in Huge Refugee Camp', The Times (30 December 2013), www.thetimes.co.uk/article/ children-are-groomed-for-war-in-huge-refugee-camp-cn 29 tjm97z5 Accessed 10 May 2016.

29 J. Van Ginneken, Understanding Global News: A Critical Introduction (London,Thou and Oaks and New Delhi: Sage, 1996).

30 Philp, 'Children are Groomed for Warr in Huge Refugee Camp'.

31 MacKinnon, Why Young Syrian Refugees will Haunt the Mideast for Decades to Come'. 
32 Galtung and Ruge, 'The tructure of Foreign News', p. 67.

33 P. Altheide, Terror Post $9 / 11$ and the Media (New York: Peter Lang, 2009).

34 J. Stokes, How to do Media and Cultural Studies: Analysing Media and Cultural Texts (London, Thou and Oaks and New Dehli: Sage, 2003).

35 S. Bazzi, Arab News and Conflict: A Multidisciplinary Discourse Study (Amsterdam and Philadelphia: John Benjamins Publishing Company, 2009); S. Franks, Reporting Disasters: Famine, Aid, Politics and the Media (London: Hurst, 2013).

36 Discussion with Abdul Majeed, UNICEF Jordan staff $\mathrm{m}$ mber in Zảatari refugee camp.

37 J. Seaton, Carnage and the Media: The Making and Breaking of News About Violence (London Penguin, 2005).

38 Philp, 'Children are Groomed for Warr in Huge Refugee Camp'.

39 MacKinnon, Why Young Syrian Refugees will Haunt the Mideast for Decades to Come'.

40 Voluntary Services Overseas, The Live Aid Legacy: The Developing World through British Eyes A Research Report (London: VSO, 2001).

41 UNICEF, Syria Crisis: Education Interrupted: Global Action to Rescue the Schooling of a Generation (UNICEF MENA, 2013), http:// unicf/2iAQ94z. Accessed 22May 2016.

42 S. Nicolai and S. Hine, 'Investment for Education in Emergencies: A Review of Evidence', Overseas Development Institute (February 2015), http:// bit.ly/2bsBRg2. Accessed 2 April 2016.

43 See http:// nolostgeneration.org/partners. Accessed 18 June 2016.

44 See http:// nolostgeneration.org/partners. Accessed 18 June 2016. The 'No Lost Generation' initiative includes multiple partners working on the Syrian and Iraqi crises across the region including, 'United Nations agencies and international andlocalNGOs, as well as governments, international donors, private sector and the young people themselves who are so aff cted by the crises in Syria and Iraq'.

45 See http:// nolostgeneration.org/partners. Accessed 18 June 2016.

46 J. Rudoren, 'Calm Boss Overseeing a Refugee Camp’s Chaos', New York Times (24 May 2013), http:nyti.ms/2btYNNV. Accessed 26 February 2016.

47 S. Parker, Interview with the athor, 29 June 2016.

48 T. Connor, 'Inside a Refugee Camp with Syria’s "Lost Generation"', NBC News (26 August $2013)$, http:// nbcnews.to/2hdLAN5. Accessed 2 March 2016.

49 S. Waisboard, 'Can NGOs Change the News?' International Journal of Communication, 5 (2011), pp. 142-65, http:// ijoc.org/index.php/ijoc/article/view/787/515. Accessed 11 April 2016.

50 J. Elgot, 'The Secret Gardens of Syria's Refugee Camps', Huffington Post (29 October 2014), http:// huff.to/ 1t0j7Y. Accessed 25 My 2016.

51 A. Vingiano, 'Syrian Children Master Taekwondo at the Za'atari Refugee Camp', Buzzfeed (2 July 2014), http:// bzfd.it/2glblHi. Accessed B June 2016.

52 Mazoun is the spelling that she uses in English for her name, in the original report the journalist spells the mame, Mizune.

53 A. Alvarado, 'Syrian Teen is Called the Malala of Za'atari', CNN International (18 April 2014), http:// cnn.it/RrgrWv. Accessed 5 June 2016. Malala Yousafzai the Pakistani schoolgirl who was shot on her way to school in 2009 and was awarded the Nobel Peace Prize fi e years later for her work in compaigning for girls' education.

54 T. Fricker, 'Students Promote Learning in Za'atari Camp, Jordan', UNICEF (12 September 2013), www.unicef.org/infobycountry/jordan_70365.html. Accessed 25 My 2016.

55 'Th ough Teenagers' Eyes: Unique Snapshots of Syrian Refugee Life', BBC (13 November 2014), www.bbc.co.uk/news/ world-middle-east-29724306. Accessed 22May 2016.

56 All children's names were changed on the orginal photo essay to protect identities. 
57 L. Polman, War Games: The Story of Aid and War in Modern Times (London: Penguin, 2010).

58 T. Luck, 'In a Jordan Camp, Outsiders Seek Syrian Brides', Washington Post (23 November 2012), http:// wapo.st/2bW56k8. Accessed 21 Ayust 2016.

59 R. Sherlock and C. Malouf, 'Syrian Girls "Sold” into Forced Marriages', Daily Telegraph (23 January 2013), http:// bit.ly/ 18XBpDT. Accessed 2 March 2016.

60 K. Taha, 'Early, Forced Marriages Haunt Jordan's Syrian Refugees', AFP (12 June 2013), http:// bit.ly/2gRRcte. Accessed B March 2016.

61 J. Halaby, 'Desperate, Some Fleeing Syria Turn to Prostitution', Associated Press (8 March 2013), http:// yhoo.it/2bvi2ct. Accessed 25 My 2016.

62 Freedom House, 'Jordan' (2014), https:// freedomhous.org/report/ freedom-press/2014/ jordan. Accessed 25 May 2016.

63 K. Abbot, 'Working Together, NGOs and Joumalists Can Create Stronger International Reporting', NiemanLab (9 November 2009), http:// bit.ly/1J7MV2. Accessed 20 July 2016.

64 United Nations Population Fund, Reporting on Gender-Based Violence in the Syria Crisis: A Journalists Handbook (UNFPA, 2014), www.unfpa.org/sites/default/files/resource-pdf/ UNFPA\%2Joumalsits\%2s\%20Handbook\%20Small\%5B6\%5Ddf.

65 S. Parker, interview with the athor, 29 June 2016.

66 Lynch and Galtung, Reporting Conflict, p. 18.

67 Seaton, Carnage and the Media.

68 S. Cottle and D. Nolan, 'How the Media's Codes and Rules Influ nce the Ways NGOs Work', NiemanLab (16 November 2009), http:// bit/ly/1FzwEsR. Accessed 3 March 2016.

69 United Nations Population Fund, Reporting on Gender-Based Violence in the Syria Crisis.

70 M. Odeh, cited in B. Al-Khatib and K. Lenner, Alternative Voices on the Syrian Refugee Crisis in Jordan: An Interview Collection (Rosa Luxemburg Stiftu g Regional Office Palestine, 2015).

71 UNICEF, A Study on Early Marriage in Jordan 2014 ( Jordan: UNICEF, 2014), www.unicef.org/ mena/UNICEFJordan_EarlyMarriageStudy2014(1).pd. Accessed 25 My 2016.

72 See www.girlsummit2) 14org/ Commitment/ Show. Accessed 3 March 2016.

73 UNICEF, A Study on Early Marriage; Save the Children, 'Too Young to Wed: The Growing Problem of Child Marriage among Syrian Girls in Jordan', Save the Children (2014), http:// bit. ly/ 1FXQIX3. Accessed $\mathbb{2}$ January 2016.

74 M. Anderson, 'Child Marriage Soars among Syrian Refugees in Jordan', Guardian (16 July 2014), http:// bit.ly/1rhUng1. Accessed 2 June 2016.

75 R. James, '21 Powerful Images of Forced Marriage Drawn by Syrian Refugees in Jordan', Buzzfeed (17 July 2014), www.buzzfeed.com/richardhjames/powerful-images-of-forcedmarriage-drawn-by-syrian-ref\#.okzMzw07K. Accessed 25 My 2016.

76 Cottle nd Nolan, 'How the Media's Codes and Rules Influ nce the Ways NGOs Work'.

77 N. Fenton, 'Has the Internet Changed How NGOs Work with Established Media? Not Enough', NiemanLab (23 November 2009), http:// bit.ly/1oCCrMB. Accessed 25 May 2016.

78 Cottle nd Nolan, Global Humanitarianism and the Changing Aid-Media Field', p. 863.

79 United Nations Population Fund, Reporting on Gender-Based Violence in the Syria Crisis.

80 R. Sweis, 'In Jordan, Ever Younger Syrian Brides', New York Times (13September 2014), http:// nyti.ms/XmbDE1. Accessed 8 March 2016.

81 Van Ginneken, Understanding Global News.

82 Altheide, Terror Post $9 / 11$ and the Media.

83 Abbot, 'Working Together'.

84 L. Tsui, 'Saving Us from Noise that Kills: NGOs as News Coordinators in a Networked Public Sphere', NiemanLab (7 December 2009), http:// bit.ly/1GPDb9x Accessed 26 February 2016.

85 M. Montgomery, An Introduction to Language and Society (Oxon: Routledge, 2008). 


\section{References}

Abbot, K., 'Working Together, NGOs and Journalists Can Create Stronger International Reporting', NiemanLab (9 November 2009), http:// bit.ly/1J7MV2. Accessed 20 July 2016.

Al-Khatib, B. and K. Lenner, Alternative Voices on the Syrian Refugee Crisis in Jordan: An Interview Collection (Rosa Luxembung Stiftu g Regional Office Palestine, 2015).

Altheide, P., Terror Post $9 / 11$ and the Media (New York: Peter Lang, 2009).

Alvarado, A., 'Syrian Teen is Called the Malala of Za'atari', CNN International (18 April 2014), http:// cnn.it/RrgrWv. Accessed 5 Jne 2016.

Anderson, M., 'Child Marriage Soars among Syrian Refugees in Jordan', Guardian (16 July 2014), http:// bit.ly/1rhUng1. Accessed $\mathbb{2}$ June 2016.

Aslam, R., 'Peace Joumalism: A Paradigm Shift in Traditional Media Approach', Pacific Journalism Review, 17:1 (May 2011), pp. 119-39, https:// pjreview.aut.ac.nz/articles/peace-joumalismparadigm-shift-traditional-media-approach-476. Accessed 1 May 2016.

Bazzi, S.,Arab News and Conflict: A Multidisciplinary Discourse Study (AmsterdamandPhiladelphia: John Benjamins Publishing Company, 2009).

BBC, 'Syria Conflict: "Biggest humanitarian crisis since 1945" - Gordon Brown' (4 February 2016), www.bbc.com/news/world-middle-east-35489063. Accessed 7 June 2016.

Bowen, J., The Arab Uprisings: The People Want the Fall of the Regime (London: Simon\& Schuster, 2012.

Bulos, N., 'Jordan Feeling the Strain of Syrian Refugee Crisis', Los Angeles Times (22 March 2013), http:// lat.ms/ 2 hftvid. Accessed 18 June 2016.

Connor T., 'Insidea Refugee Camp with Syria’s “Lost Generation”', NBC News (26 August 2013), http:// nbcnews.to/2hdLAN5. Accessed 2 March 2016.

Cooper, G., 'When Lines between NGO and News Organization Blur', NiemanLab (21December 2009), http:// bit.ly/1DpvRKL. Accessed 11December 2015.

Cottl , S. and D. Nolan, 'Global Humanitarianism and the Changing Aid-Media Field', Journalism Studies, 8:6 (2007), pp. 862-78.

Cottl , S. and D. Nolan, 'How the Media's Codes and Rules Influ nce the Ways NGOs Work', NiemanLab (16 November 2009), http:// bit/ly/1FzwEsR. Accessed 3 March 2016.

Curran, J., Media and Power (London and New York: Routledge, 2002).

Elgot, J., 'TheSecret Gardens of Syria's Refugee Camps', Huffington Post (29 October 2014), http:// huff.to/ 1t0j7V. Accessed 25 My 2016.

Fenton, N., 'Has the Internet Changed How NGOs Work with Established Media? Not Enough', NiemanLab (23 November 2009), http:// bit.ly/1oCCrMB. Accessed 25 My 2016.

Franks, S., Reporting Disasters: Famine, Aid, Politics and the Media (London: Hurst, 2013).

Freedom House, 'Jordan' (2014), https:// freedomhou@.org/ report/ freedom-press/ 2014/jordan. Accessed 25 May 2016.

Fricker, T., 'Students Promote Learning in Za'atari Camp, Jordan', UNICEF (12 September 2013), www.unicef.org/infobycountry/jordan_70365.html. Accessed 25 My 2016.

Galtung, J. and M. H. Ruge, 'TheStructure of Foreign News', Journal of Peace Research, 2:1(1965), pp. 64-91.

Girl Summit Girl Summit (2014), www.girlsummit214org/Commitment/Show. Accessed 25 May 2016.

Halaby, J., 'Desperate, Some Fleeing Syria Turn to Prostitution', Associated Press (8 March 2013), http:// yhoo.it/2bvi2ct. Acessed 25 Myy 2016.

Healy, S. and S. Tiller, 'A Review of the Humanitarian Response to the Syrian Refugee Crisis in Jordan 2012-13, MSF (October 2013), www.msf.org.uk/sites/uk/files/ jordan_case_study_ fi al_external_0.pdf. Accessed 25 My 2016. 
James, R., '21 Powerful Images of Forced Marriage Drawn by Syrian Refugees in Jordan', Buzzfeed (17 July 2014), www.buzzfeed.com/richardhjames/ powerful-images-of-forced-marriagedrawn-by-syrian-ref\#.okzMzw07K. Accessed 25 My 2016.

Keane, F., 'Syria: TheBoys Who Helped Spark a Revolution', BBC (13 April 2013), http:// bbc.in/ 2bGPPwq. Accessed 25 My 2016.

Kirlpatrick, D., 'Syrian Children Off r a Glimpse of a Future of Reprisals', New York Times (3 September 2012), http:// nyti.ms/2h8HBBg. Accessed 2 April 2016.

Luck, T., 'In a Jordan Camp, Outsiders Seek Syrian Brides', Washington Post (23 November 2012), http:// wapo.st/2bW5bk8. Accessed 21 A Agust 2016.

Lynch,J. andJ. Galtung, Reporting Conflict: New Directions in Peace Journalism (Brisbane: University of Quensland Press, 2010).

Lynch, J. and A. McGoldrick, Peace Journalism (Stroud: Hawthom Press, 2005).

MacKinnon,M., 'Why Young Syrian Refugees will Haunt the Mideast for Decades to Come', The Globe and Mail (14 September 2013), http:// bit.ly/1k8a5Z2Accessed B May 2016.

Montgomery, M., An Introduction to Language and Society (Oxon: Routledge, 2008).

Nicolai, S. andS. Hine, 'Investment forEducationinEmergencies: AReview ofEvidence', Overseas Development Institute (February 2015), http:// bit.ly/2bsBRg2. Accessed 2 April 2016.

No Lost Generation (2016), http:// nolostgeneration.org/ partners. Accessed 18 June 2016.

Oddone, E., 'Azraq Refugee Camp Officially Opened', The Jordan Times (30 April 2014), http:// bit.ly/28T4a6F. Accessed 10 May 2016.

Parker, S., Interview with the athor, 29 June 2016.

Philp, C., 'Children are Groomed for War in Huge Refugee Camp', The Times (30 December 2013), www.thetimes.co.uk/article/children-are-groomed-for-war-in-huge-refugee-campcn29tjm97z5 Accessed 10 May 2016.

Polman, L., War Games: The Story of Aid and War in Modern Times (London: Penguin,2010).

'Post-Truth Politics: Art of the Lie, Economist (10 September 2016), http:// econ.st/2bVXLHU. Accessed 20 October 2016.

Rudoren, J., 'Calm Boss Overseeing a Refugee Camp's Chaos', New York Times (24 May 2013), http:nyti.ms/2btYNNV. Accessed 26 February 2016.

Save the Children, 'Too Young to Wed: The Growing Problem of Child Marriage among Syrian Girls in Jordan', Save the Children (2014), http:// bit.ly/1FXQIX3. Accessed D January 2016.

Seaton, J., Carnage and the Media: The Making and Breaking of News About Violence (London Penguin, 2005).

Sherlock, R. and C. Malouf, 'Syrian Girls "Sold” into Forced Marriages', Daily Telegraph (23 January 2013), http:// bit.ly/18XBpDT. Accessed 2 March 2016.

Simpson, J., We Chose to Speak of War and Strife: The World of the Foreign Correspondent (London: Bloomsbury, 2016).

Stokes, J., How to do Media and Cultural Studies: Analysing Media and Cultural Texts (London, Thou and Oaks and New Dehli: Sage, 2003).

Sweis, R., 'In Jordan, Ever Younger Syrian Brides', New York Times (13 September 2014), http:// nyti.ms/XmbDE1. Accessed 8 March 2016.

Taha, K., 'Early, Forced Marriages Haunt Jordan’s Syrian Refugees', AFP (12 June 2013), http:// bit. ly/2gRRcte. Accessed B March 2016.

'Th ough Teenagers' Eyes: UniqueSnapshots of Syrian Refugee Life', BBC (13 November 2014), www.bbc.co.uk/news/world-middle-east-29724306. Accessed 22 May 2016.

Tsui, L., 'Saving Us from Noise that Kills: NGOs as News Coordinators in a Networked Public Sphere', NiemanLab (7 December 2009), http:// bit.ly/1GPDb9x Accessed 26 February 2016. 
UNICEF, Syria Crisis: Education Interrupted: Global Action to Rescue the Schooling of a Generation (UNICEF MENA, 2013), http:// unicf/2iAQ94z. Accessed 22May 2016.

UNICEF, Shattered Lives: Challenges and Priorities for Syrian Children and Women in Jordan ( Jordan: UNICEF, 2013), www.unicef.org/mena/MENA_Shattered_Lives_Junell.pdf. Accessed 9 May 2016.

UNICEF, A Study on Early Marriage in Jordan 2014 ( Jordan: UNICEF, 2014), www.unicef.org/ mena/UNICEFJordan_EarlyMarriageStudy2014(1).pd. Accessed 25 My 2016.

United Nations Population Fund, Reporting on Gender-Based Violence in the Syria Crisis: A Journalists Handbook (UNFPA, 2014), www.unfpa.org/sites/default/files/resource-pdf/ UNFPA\%20Joumalsits\%2 s\%20Handbook\%20Small\%5B6\%5Ddf. Accessed 25 My 2016.

Van Ginneken, J., Understanding Global News: A Critical Introduction (London, Thou and Oaks and New Delhi: Sage, 1996).

Vingiano, A., 'Syrian Children Master Taekwondo at the Za'atari Refugee Camp', Buzzfeed (2 July 2014), http:// bzfd.it/2glblHi. Accessed B June 2016.

Voluntary Services Overseas, The Live Aid Legacy: The Developing World through British Eyes A Research Report (London: VSO, 2001).

Waisboard, S., 'Can NGOs Change the News?' International Journal of Communication, 5 (2011), pp. 142-65, http:// ijoc.org/indexphp/ijoc/article/view/787/515. Accessed 11 April 2016.

Wilkes, S., 'Jordan Opens New Camp for Syrian Refugees AmidFunding Gaps', UNHCR (30 July 2012), http:// bit.ly/2b7nnq. Accessed 21 May 2016. 


\title{
Selling the lottery to earn salvation: Journalism practice, risk and humanitarian communication
}

\author{
Jairo Lugo-Ocando and Gabriel Andrade
}

Regarding the need of an eff ctive humanitarian communication that can politically assist mobilisation and public engagement, many scholarly works have focused upon the ability of the news media to create regimes of pity in order to mobilise the public towards humanitarian causes. ${ }^{1}$ Some authors have gone further to say that if audiences are passive and uninterested, sometimes the media have to stand in for them, and agitate on theirbehalf. ${ }^{2}$ Thekey argument of those who advocate for these regimes is that they enable empathy and solidarity by means of emotions.

However, pity has been subject to criticism by some authos. ${ }^{3}$ Philosophers of a Nietzschean strand, for example, believe that pity is in fact a corrosive emotion, deeply inculcated in our culture by Judaism and Christianity and more recently shared by socialist ideologies. ${ }^{4}$ In their view, pity is not a proper way to promote others' wellbeing, in as much as it diminishes the other person's potential for selfreliance. To a certain extent, we tend to agree with this stance as in our view these regimes of pity tend to obviate, all too often, the power relations between those who suff $r$ and the spectators. ${ }^{5}$

In this context, charity events promoted as 'media events' have become spectacles in themselves (e.g. concerts such as Live Aid, in 1985), and although they may serve the public good in the short term - i.e. by raising funds for a particular campaign - in the long term they actually contribute to further detachment from moral concerns. ${ }^{6}$ Moreover, such events contribute to shape what philosopher Guy Debord called the 'spectacle society'; this to the point that victims of suff ring become themselves objects of entertainment.? To put it bluntly, these charity actions give 'black' children in Africa their fifteen minutes of fame while reassuring once again the quasimessianic role of the 'white man's burden' in the international system by means of international aid. $^{8}$

What is needed instead, as we argue here, is a type of news coverage that creates a specific type of political solidarity. One which makes individual at both sides of the screens see each other as equals and as having the same rights and which does not reproduce the same type of power relations that have been prevalent until now 
in most news narratives and humanitarian campaigns. In order to achieve this, journalism practice requires to set asidethe sense of power and certainty that articulates in its news narratives and adopt instead a view of 'shared risk' in which people embrace equally concerns about a common future, therefore calling into play the principle of average utility. ${ }^{9}$ Our thesis is that by doing this, 'risk' could be joumalistically narrativised as a more rational process in our daily lives rather than just be assumed in terms of irrational 'fear'. One which advances a shared view of society that is equally empathetic to challenges such as porerty and environment.

To us this is possible because the notion of societal risk tends to create the type of collective uncertainty that brings about political action in ways that pity regimes do not. In other words, individuals who do not know what their position in society might be in the future are more willing to undertake the type of actions that will address the underlining collective issues that aff ct our society. In relation to this, Pierre Rosanvallon has pointed out that in times of uncertainty 'we all become equals. ${ }^{10}$ By this he suggests that individual are more willing to subordinate their individualaims and aspirations, and make sacrifi es, if they perceive that what it is in play could ako aff ct them both as an indvidual and as a ommunity. ${ }^{11}$

Ths is not only a theoretical assumption. In fact, some audience research has showed that in news beats such as the environment, the notion of collective risk is abler to trigger political action amongst larger segments of society than other issues of public concern. ${ }^{12}$ Th s because the notion of risk is closely linked to vulnerability and therefore if articulated properly it conveys a real possibility that could aff ct anyone as an individual regardless of their current social status. In those cases, as this body of research indicates, there is a greater chance that people might be willing to engage and sacrifi e individual prerogatives, go against individualinterests and support collective responses towards reducing the isks posed to them.

In order to explain how this notion of risk could be incorporated into journalism practice, we need however to fi st explain the link between collective risk and individualaction in the context of social vulnerability. In this sense, the late philosopher John Rawls pointed out that when the parties are deprived of all knowledge of their personal characteristics and social and historical circumstances, their onception of justice becomes one that advances their interests in establishing better conditions for all. Rawls contends that the most rational choice for the parties in the original position are two principles of justice: The fi st principle guarantees the equal basic rights and liberties needed to secure the fundamental interests of free and equal citizens and to pursue a wide range of conceptions of the good. The second principle provides fair equality of opportunities and it secures for all a guaranteed minimum of all-purpose means. In other words, according to this principle if ' $I$ ', as an individual ignore the situation I will be in danger in the near future. Consequently, ' I' am more inclined to opt for a more redistributive social welfare policy because it could be the case that 'I' will need to make use of it at some point in the face of the uncertainty around my own circumstances. 
It is by no means absolutely clear, however, how we shouldunderstand 'equality of opportunities' in this context, and what policies can ensure it. At somebasiclevel, 'equality of opportunities' implies equality in terms of the law, something that was widely debated amongst diff rent factions during the French Revolution. ${ }^{13}$ Indeed, liberal doctrines, such as those embedded in the constitution of the United States and which have been so influ ntial in shaping modern journalism, frequently proclaim 'all men are created equal. In that tradition what this means is that no citizen shall be above the hw, and that every citizen must get the same legal treatment.

Yet, there is no philosophical agreement as to what comes next. Egalitarians of a stronger bent believe that equality before the law is not just enough. Communists, for example, believe that, as long as there is no equality of outcomes, society will be unjust. ${ }^{14}$ In this view, everyone shall end the race, so to speak, without winners or losers. Other voices, however, prefer an intermediate approach. For them, equality of outcome is not desirable, for the simple fact that it is not fair According to this tradition, some people do make a greater effo t than others, and thus, do deserve more. They argue that equality of outcomes takes away motivation and incentives for further production, and thus, will end up hindering the total utility measure. It is precisely for this reason that Rawls did not endorse socialism or communism. Such systems of wealth distribution, end up aff cting negatively even the least well-off in society. Th re must be winners and losers; otherwise, no one will have incentives to keep running according to Rawls. ${ }^{15}$

Nevertheless, those moderated philosophers who reject equality of outcomes, would nevertheless uphold some form of wealth redistribution in order to ensure equality of opportunities. For them, the race was not fair from the start. Some runners had initially greater obstacles than others. And thus, in order to make it truly fair, these philosophers believe that some sort of wealth redistribution is necessary, in order to correct the initial disadvantages of the least well-off. For them, the institution of inheritance, for example, invites a lot of refl ction about its faimess. Do inheritors deserve what they get? Is it not an additional, undeserved advantage that erodes equality of opportunity? And yet, other philosophers believe that even if, indeed, there are plenty of injustices in the world, there is not much that we can do about it, because interventions would imply a great violation of individual rights. Nozick, an example of this school of thought and who extensively debated with Rawls about these matters, challenged this point of view. ${ }^{16} \mathrm{He}$ invited us to think about the injustice in the face of millions of people with defective kidneys, something they could not foresee or plan for. Does that warrant somesort of forced kidney redistribution in order to ensure a stronger equality of opportunities? Others, such as Sowell, reinforced this critique by arguing that the nation state can attempt to correct some social injustices, but it must renounce its attempts to pursue cosmic justice. $^{17}$

Ths particular debate, we fin, is crucial in addressing the transformations and changes that are taking place in the realm of humanitarian communication. 
Particularly because they help explain the current tensions between journalistic narratives that emphasise palliative measures and more radical narratives around structural change, which in many ways refl ct these debates. While journalism covering suff ring normatively advocates for assistance and equal opportunities it nevertheless also tends to suggest that cosmic justice is unviable. That issues such as corruption, lack of institutional framework and 'civilised' political engagement in these societies are notonlythe root causes of the problems theyface butalso endemic to them. Th se philosophicaldebates also underpin another very important tension between those who see joumalism as a neutral player that presents the facts to the public so they can make their own mindand those who see journalism advocating for certain causes. Ths is of course a false dichotomy as in both cases the ultimate goal of journalists is to achieve social justice despite normative claims of neutrality. ${ }^{18}$ Th s tension is also present between journalists advocating for equality of outcomes and those advocating for equality of opportunities. In the context of humanitarian communication there shouldbe no doubt; journalism is nomatively committed to helping those who suff $r$. The weight of each of these tensions is however not equal and some are far more influ ntial than others in shaping the news. All this in addition to, as we will discuss later, important tensions between journalism and humanitarian communication as §cial practices.

Overall, the domimant journalism narrativisation of humanitarian crisis is one that is currently interlocked with a rationale which assumes that if it exposes tragedy, then individuals wouldbe more willing to donate as it sees pity as condudive to empathy and solidarity. ${ }^{19}$ After all, it appeals to the moral and ethicalunderstanding that those who suff $\mathrm{r}$ will be assisted by those who are better off because pity will make them 'feel' a moral responsibility to do so. Hence, it is expected that in light of suff ring, people will engage and act towards theirfellow citizens as soon as this suff ring is exposed on their sreens. ${ }^{20}$

However, it is far from clear if, in fact, the exposure to deep suff ring does indeed lead to greater moral concern for the wellbeing of others or triggers politicalaction. ${ }^{21}$ Furthermore, the problem is that this approach assumes that these values are universally shared, something that is also far from certain. Th s approach also has the problem that it assumes that joumalists are intentionally seeking to promote this type of empathetic link between audiences and those suff ring as part of their deontological practice, which again is not certain in all cases. Hence, we are left with a theoretical explanatory framework of why and how joumalists narrativise suff ring, which is mostly based on assumptions around nomative claims and ethical aspirations that are far from universal.

\section{Moving forward}

However, our aim in this chapter is not to explain motivation and agency of the current journalism narrativisation of suff ring, which in fact has been diligently 
and comprehensively discussed by a series of authors. ${ }^{22}$ Instead, we want to articulate an alternative to it, in ways in which joumalism could realistically, within its deontological constraints, contribute to addressing the structural problems that cause this suff ring in the fi st place. Our thesis here is that by changing the terms of this narrativisation, journalists could still inform their publics in ways that it would make it more clear to them what that suff ring means and how it links to them as individuals.

At the centre of this proposal we argue for the need to incorporate the notion of risk. By this we mean that it is possible and desirable for journalists to link the notion of the principle of average utility exposed by Rawls, given that the 'the veil of ignorance' would insure impartiality of the audiences' judgement towards those in need, making them more willing to participate and engage with collective responses. Indeed, we believe that if joumalism that covers human tragedy can articulate their stories withina framework that somehow manages to bring about uncertainty in the perspective of their audiences it could achieve a far more eff ctive type of empathy; one that can be better placed to mobilise towards solidarity. Consequently, journalism, as a professional body, could then contest not only the utilitarian ethics that currently dominates humanitarian news but also overcome the restrictions imposed by the nomative claims that it is there just to inform about tragedy.

Yet, in order to advance a new type of humanitarian narrative, journalists will need to re-interpret their contractual relation with society. Th s means revisiting the social arrangements in which they are allowed to operate semi-protected by society in exchange for performing the duty of keeping the democratic citizenship well informed in an 'objective' and 'balanced' manner. Hence, the question remains: How can joumalists incorporate the notions of risk in their stories so as to foster public engagement and solidarity? Answering this question is made more difficult by the imperatives imposed by traditional news values such as that of objectivity/neutrality/ detachment and by other elements related to the process of news production such as the structure that joumalists commonlyuse to articulate news stories. The possible answer is further complicated by the emergence of a new technological landscape that in itself poses important challenges. Conversely, if we are able to provide a sound answer to this question, one that can translate into political action within the journalism profession, then we could help solve one of the key problems facing both joumalists and activists working in the humanitarian fi ld.

The problem is that Western journalism deontology relies heavily on the strand of ethical thought that promotes the idea that ethics does not need any measure of empathy. Joumalism deontological ethicists advance the claim that moral action is to be performed on account of duty, regardless of how we feel about it. Accordingly, it is claimed, it is our imperative to help others in need, irrespective of whether or not we feel other people's suff rings. Furthermore, if we are motivated to help others, not on account of duty, but rather, because we feel their own pain, we would be acting immonlly. Ths approach, traditionally associated with Immanuel Kant 
(1724-1804), is frequently viewed as too restrictive but nevertheless closely linked to joumalism practice and nomative claims. ${ }^{23}$ Indeed, as journalism ethics go, the presentation of factualevidence and data to the public shouldbe sufficient to allow them to make a rational decision. Ths decision is expectedly one that should underpin solidarity given the fact that it is assumed that audiences would feel a moral duty to act, irrespective of whether they feel the pain of others or not.

\section{What type of risk?}

Generally speaking, the reporting of risk and vulnerability in the context of humanitarian crises remains an area that is largely under-researched. Th $s$ is so, despite calls from scholars such as SimonCottle who in 1998 pointed out the need to embrace in media studies the notion of the 'risk society. ${ }^{24}$ Moreover, the notion of risk within globalisation has been duly noted by authors such as Beck, Peter Bernstein, Niklas Luhmann and Rifkin, amongst others. ${ }^{25}$ According to Anthony Giddens, our society is increasingly preoccupied with the future, something that pushes to the centre stage the notion of risk. ${ }^{26}$ Historically speaking, the notion of risk derives from the uncertainties that modernity has created. It is overall diff rent from how we, as a society, viewed risk in the past when risk was accepted and even embraced as an unavoidable part of life. ${ }^{27}$ The arrival of modernity has instead co-opted risk into the sphere of fear and today, far from accepting the odds of destiny (to paraphrase Sophocles), we now seem to live under the theat of unertainty.

In this sense, the advent of the 'market society', which Karl Polanyi refers to, marked a fundamental change in the mentality of humankind towards risk.$^{28}$ For Niklas Luhmann, the rationalisation of 'risk' in terms of the market had an important eff ct on the way it is defin d by society. ${ }^{29}$ Th s meant that over the following years, a utilitarian notion of risk took over; one which equated to fear and that became prevalent. In ourtimes we see and narrativise risk as a pervasive threat. Yet, and despite this narrativisation, risk needs to be valued and understood in diff rent ways. Rawls, for example, recommends a safety net and a welfare state that may support the least well-off, by making the rational calculation that, if we did not know what our position will be (i.e. if we were under the veil of ignorance), we would avert risk. ${ }^{30}$ In such a manner, we would ensure that the least well-off would be properly attended. ${ }^{31}$ The core element of this view around risk is that it introduces the notion of 'prudential social morality'. Certainly the idea of mutually benefi ial co-operation underpins the Rawlsian original position on 'justice faimess', one that is supported by the tradition of humans coming together, collectively, to face risk. ${ }^{32}$

Th s contrasts sharply with what professional journalism does in regards to the coverage of distant suff ring as it tends to individualise the responses to risk, particularlyin relation to suff ring. Thenarrativisation of suff ring is in fact characterised by 'assistencialism', that is 'individuals extending the hand to other individuals' in the context of voluntary and charity effo ts. Because of this, most news stories gravitate 
around 'intervention' from the helping hand of the West, whichinvariably comes to the rescue of those in need. However, the root causes of suff ring are rarely discussed in these reports, whichkeep recycling prevalent explanatory frameworks about why these people suff $\mathrm{r}^{33}$

Foreign intervention in the face of distant suff ring is central in the joumalistic narrativisation of suff ring because it is mostly presented as an event that seems only to aff ct those in developing countries. Journalistic advocacy then concentrates upon the need to guarantee that palliatives - i.e. donations and foreign aid - are in place to assist the individuals, while effo ts are made to reduce 'compassion fatigue' by increasing the tone and dramatic features when reporting suff ring and emphasising the theatricality in the style. ${ }^{34}$ In this way, journalists covering famine, natural disasters or war try to create a link between the 'distant' suff ring that happens to 'others' and those at home watching the news. Risk, in these terms, is a notion that remains detached and abstract to those in theWest.

However, in the past few years the political context has been changing. Massive waves of migration, the fi ancial crisis of 2008 and the increasing terrorist threats in the West have suddenly brought risk home. Indeed, joumalism faces a new and unprecedented context in which traditional explanatory frameworks and narratives are becoming unviable. The transformation of humanitarian communication, which Lilie Chouliaraki refers to, is setting new and more demanding parameters for reporters, who now need to question more critically structural reasons for that suff ring and go beyond the comfort zone off red by the neutrality of charity work and aid. $^{35}$

\section{Re-narrativising suffering}

The transformation of humanitarian communication is in fact creating important tensions within joumalism practice. On the one hand, we find that traditional normative claims of balance and detachment when reporting the suff ring of others are increasingly tested by the ever-closer links between journalists, corporations, NGOs and governments in the face of news production defi its and the increasing role of public relations. ${ }^{36}$ On the other, we find that the depoliticisation and fragmentation of audiences and dislocation of the news media landscape is pushing the ability of journalists to connect with their audiences to the extremes. In both cases, these tensions create a situation in which traditional narratives towards suff ring seemed exhausted or are quicky undermined.

Take for example the news coverage of famines and how it mostly remains anchored in reporting of these events within the regimes of pity. In these cases, the ability of the news media to mobilise the publics has becomelimited andineff ctive. The 'compassion fatigue' which Moeller speaks about is a situational variable, rather than a personality trait in which contemporary media coverage contributes decisively to exhaust people's engagement with social problems. ${ }^{37}$ In other words, 
people get saturated and feel disempowered hence feel the need to detach themselves from the issues being reported. Th $s$ is particularlyaggravated by the recurrent coverage of issues that seem to be never resolved. Th $\mathrm{n}$ the charity sectors, multilateral agencies and the media fall into the trap of intensifying the coverage both in terms of frequency and dramatic exposure with the hope that this would re-engage the audience. Th s, of course, rarely happens and it rather ends up exhausting even more the audiences, who then seem to completely disengage from international humanitarian issues.

To overcome these tensions journalism ought to redefineits approach to humanitarian news. In our view, this will require incorporating the notion of risk. To do so, journalists will need to make sure that what they report relates to the individuals at the other side of the screens. Ths relationship needs to be based upon creating awareness around shared risk by asking key questions about how the distant suff ring aff cts all. However, is it really realistic to expect that people in the global North understand, assume and feel risk in the same manner as people in the global South? After all, those living in the North live in conditions that make it very unlikely that they will ever have to confront the same type of humanitarian risks as those in the South, and chances are they never will.

To advance the discussion let us refer fi st to what we know about people's attitudes towards probability and the key questions posed by the average utility principle by asking some basic questions: Am I likely to need humanitarian assistance? Is tragedy likely to happen to me as an individual? And how likely is it to happen to me? To explore this, let us invert the situation from negative risk (that is the risk of losing) to positive risk (ergo the probability of winning). In relation to this, research on lottery consumption confi ms that heavy players are found to have less income and to fantasise more than light players. Th se heavy lottery players are also more prone to risk-taking. ${ }^{38} \mathrm{So}$, those who have less tend to take more risks with their disposable income while those who have higher incomes tend to be more risk-adverse (at least in relation to the probability of winning). Another important fin ing in this body of research is the phenomenon of 'anticipatory regret', that is those who buy the lottery because they would find it intolerable to discover their regular numbers had been drawn when they had not purchased a ticket. That is, people who play the lottery are not inclned to take the risk of mssing out on winning..$^{39}$

We refer to the lottery case as it perfectly exemplifi s our argument, that despite having a low probability, people nevertheless are convinced by media campaigns and advertising to buy the lottery because 'it could be you' (although some also buy it for charity reasons). Ths, to us, provides a window of opportunity to explore the narrativisation of risk within humanitarian communication and particularly in relation to joumalism covering suff ring. Indeed, if media campaigns and advertisement are able to convince people to buy the lottery despite minimum probability of wining, why can't we do the same in relation to convincing people to invest in the same way their dsposable income in the fre of losing' in a posible humanitarian crisis? 
Thefi st challenge we would face would be to take the journalistic narrative to a meta-geographic level. Reporters covering in Africa, Asia and Latin America tend to create common codes when reporting events such as the economy or national elections. So political parties are narrativised as being on the 'left' or on the 'right' while a variety of economic systems tend to be amalgamated into free-market or state-run. Th $s$ allows the audiences to understand those aspects of those societies in similar terms to theirown and draw, for example, conclusions to theirown realities. Consequently, by reading the coverage of places such as Zimbabwe and Venezuela (with their economies crumbling), readers are left with the risk-awareness that voting for pro-state-run economy parties could do the same to their own societies. Th s, however, does nothappen in the case of humanitarian disasters where very few common codes between audiences and events are created, therefore limiting any bridges that could create similar patterns of risk-awareness. Instead, what we findis news coverage that overemphasises geographical distance.

Th s spatial detachment is key in limiting the ability of audiences to see and feel the proximity of humanitarian risk, which is why journalistic narratives tend to focus on individuals who are connected. Hence, a US news media outlet reporting a hurricane in Bangladesh will highlight if there were any US citizens killed or injured, a UK outlet reporting a tsunami in Samoa would do the same, and so on. However, proximity in the news media is already in many occasions a meta-geographical criterion in the selection and narrativation of news. Th $s$ is because the risk-awareness links - epitomised in the notion 'that could happen to me' - are also established in relation to dimension, cultural background, historical links, amongst other elements. Ths has been the case of several humanitarian crises in relation not only to the amount of coverage provided but also in relation to its distinctive nature. ${ }^{40}$ To be sure, humanitarian crises triggered by natural disasters in countries such as New Zealand tend to receive more news coverage than others in places such as Pakistan despite the magnitude and death toll of the htter being greater.

The second challenge is that risk-awareness can become a discursive mechanism to further detach the audience from those who suff $r$ by fostering fear and individualistic responses to the perceived threat. If people perceive human tragedies as a threat, then the danger is that they could entrench themselves in political isolationism as a way of protecting themselves. Ths also is one of the biggest rebuttals to the viability of the 'regimes of pity' as a communication strategy as it is exemplifi $\mathrm{d}$ by the case of public attitudes towards homeless people in big metropolises. Only a few people feel the 'compassion' to give money to the beggar while most pass by indiff rently or cross to the other side of the road to avoid that person altogether because of the ferr of cime. c1 $^{41}$

To illustrate this further, it is worth reminding ourselves that if recent waves of Syrian migrants into Europe initially met with sympathy and empathy, the continual $\mathrm{fl} \mathrm{x}$ of those groups entering the continent and the links that public discourses established between them and issues such as terrorism and rape - widely exploited 
by right-wing populist politicians and media - have created a climate of fear. Indeed, a major Ipsos MORI survey across twenty-two countries worldwide provides an insight into attitudes to immigration and the refugee crisis. Ths studyhighlights that six in ten people across these countries are concerned about terrorists pretending to be refugees, while fourin ten want to close borders entirely.2 The danger that riskawareness becomes moral panic and its use for political scaremongering is in fact one of the mos difficult challenges for the poposed narrativisation ofrisk.

The third challenge to the narrativisation of risk is presented by the established values in joumalism cultures which demand objective truth based on the presentation of balanced views, corroborated facts and unbiased interpretation of the events. ${ }^{43}$ In order for joumalists to be accepted as part of a legitimate community they have to be seen to comply with these demands. Th $s$ is what Maras calls procedural objectivity. ${ }^{44} \mathrm{Th}$ s in itself does nothinder the possibility to narrativise risk, as it would still be possible to do so in the terms of balanced and unbiased information. Theproblem arises from the concept of 'truth' itself, whichin journalism philosophy is assumed in terms of unbiased interpretation of facts. ${ }^{45} \mathrm{Th} s$ goes against the principle of truth in humanitarian communication which is one defin dinstead by social justice. To explain this succinctly: how can individuals committed in principle not to do advocacy do advocacy? After all, part of the deal of humanitarian communication is to engage and mobilise the audiences in order to address the suff ring of others (achieve justice). However, this means in practice convincing the public of the merits of the ideas and principles related to solidarity, which in Western society remain the building stones of Christian propaganda. In contrast, contemporary joumalism, developed as a by-product of the Enlightenment project normatively embraces an epistemology that attempts to make a clear distinction between a public rational sphere dominated by reason (built upon science and objective facts) and a private sphere, which contain emotions, faith and opinion Ths means presenting facts to the public and then, supposedly, allowing each individual to make their own mind (the dilemma between collective and individual interpretations is also a result of joumalism being a collateral outcome of the Enlightenment project).

Ths makes joumalism incompatible with humanitarian communication aims as the 'means' of each one seem to be at odds. Journalism has tried to resolve this by embracing the regimes of pity as it allows the presentation of suff ring as a fact in a detached and subordinated manner; where the international donors have the power to save those who suff $r$ but no legal, fi ancial or political responsibility except a moral one to do so. Ths moral solidarity, as we discussed earlier in this chapter, is predicated upon the values of empathy and pity, which happen to be - in our view incompatible. One can onlyfeel empathy for those who we see as equals. Pity, on the other hand, is felt for those who we see as beneath us, to put it metaphorically; it is a patronising approach. Moreover, while pity allows you to off $r$ sympathy and charity, empathy creates a political responsibility. Th $s$ is why the notion of the average utility risk is so powerful, because it immeliately makes us see the others as equals. 


\section{Conclusion: overcoming the challenges}

Thefi st priority of journalism is therefore to reconcile its own nomative demands for scientific procedures in seeking truth with the implicit demands of humanitarian communication for advocacy. The second is to create a connection between the presentation of humanitarian crises and the need for collective responses within the parameters mentioned above. In both cases joumalists can learn from what has happened with the news coverage of environmental news and in particular in relation to the way the reporting of the global warming threat has evolved in the past few years. Thelessons from this particular news beat shows that it is possible to narrativise risk withoutcreating moral panic while retaining the key rational elements that risk off rs that make people change patterns of behaviour.

Indeed, once it became clear that global warming eff cts would be 'inevitable' and 'generalised' then it became narrativised in a way that pushed for collective action. After all, if sea levels rise and freak weather becomes more common, this will aff ct all, not only a few. Today, despite isolated examples amongst pro-climatechange-denier news media outlets such as Fox News in the United States and the Daily Telegraph in the UK, most news media outlets and journalists approach and present global warming as a collective risk that will aff $\mathrm{ct}$ all. Ths is not to paint a rosy picture of environmental news coverage. On the contrary, journalists covering humanitarian crisis can learn even more from the mistakes made in the news beat of environment.

To be sure, media reports of environmental science often give equal weight to opposing viewpoints, making science appear more controversial than it actually is, therefore influ ncing risk and uncertainty perceptions. ${ }^{46}$ By complying with the notion of supposed bias journalists in fact provide a distorted view of reality. Moreover, in recent years there has been a consensus that has been galvanised towards a news agenda that recognises collective response and global risks in the environmental news beat. Th s despite constant and robust attemptsby corporation and government lobbies to bring these responses into the individualistic and utilitarian realm by presenting environmental risks as an 'individual choice'. Instead of succumbing to this pressure, in recent years a big and very influ ntial segment of the news media is now above and beyond these lobby attemptsand environmental risk is now a key mobiliser for ollective responses in the nows narratives.

Can joumalism do the same in relation to humanitarian crises? Theanswer is yes. We argue that by linking humanitarian risk with 'poverty risk' it is possible to galvanise this type of consensus around risk. Ths is because 'poverty risk' - that is the danger of one becoming destitute - tends to influ nce public opinionin similar ways as climate change does. ${ }^{47}$ If news coverage of humanitarian crises can highlight that these events occur because of destitution as a result of inequality, then there is a greater chance that people will feel the need to engage in terms of collective responses to humanitarian crises. 
However, the question remains as how to bring the Rawlsian principle into journalistic narratives. In this sense, the job of joumalists reporting humanitarian crisis may not be so much to present images of suff ring people, not even to persuade audiences that those tragedies happen, but rather, to expose audiences to the 'possibility' that they might happen to those looking at the screens. Th s chapter does not intend to resolve the practicalities that will derivate from trying to achieve the above. However, any effo t to introduce risk and conciliate journalism and humanitarian communication will require that joumalists rethink what they conceive as 'truth' and embrace this in theirdaily practice. Th s means that they will need to overcome the limitations inherited from the Enlightenment project with regards to both ethical conceptualisation and practical elements. ${ }^{48}$ Th $\mathrm{s}$ is, for us, the future task for scholars and practitioners.

\section{Notes}

1 L. Boltanski, Distant Suffering: Morality, Media and Politics, trans. G. D. Burchell (Cambridge: Cambridge University Press, 1999); L. Chouliaraki, The Ironic Spectator: Solidarity in the Age of Post-Humanitarianism (Cambridge: Polity Press, 2013); S. D. Moeller, Compassion Fatigue: How the Media Sell Disease, Famine, War and Death (New York and Abingdon: Routledge, 1999).

2 J. Seaton, Carnage and the Media: The Making and Breaking of News about Violence (London Allen Lane, 2005), p 286.

3 L. Chouliaraki, 'Post-Humanitarianism: Humanitarian Communication beyond a Politics of Pity', International Journal of Cultural Studies, B:2 (2010), p. 107.

4 W. A. Kauffman, Nietzsche: Philosopher, Psychologist, Antichrist (Princeton: Princeton University Press, 2008).

5 J. Lugo-Ocando, Blaming the Victim: How Global Journalism Fails Those in Poverty (Londor Pluto Press, 2014), p 172.

6 D. Dayan andE. Katz, Media Events: The Live Broadcasting of History (Cambridge, MA: Harvard University Press, 1994).

7 G. Debord, The Society of the Spectacle, trans. D. Nicholson-Smith (New York: Zone Books, 1994 [1967]).

8 W. Easterly, The White Man's Burden: Why the West's Efforts to Aid the Rest Have Done So Much Ill and So Little Good (London: Penguin,2006).

9 J. A. Rawls, A Theory of Justice (Cambridge, MA: Harvard University Press, 1971). It is important to underline that average utility as a concept is not universally accepted by philosophers, and philosophical refl ctions about it may lead to some paradoxes. If our moral objective is to increase average utility at all costs, then it wouldbe quite easy to simply reduce population size (not necessarily through coercive methods, such as in China's onechild policy, but simply through more persuasive birth controls). In this case, we would have a smaller population, with a higher mean measure of happiness. Th s would imply that a country with 100 people and an average utility of 100 units is more desirable than a country with 1,000,000 people, and an average utility of 99 units Th s is counter-intuitive, and it calls into doubt that average utility is in fact the right criterion. Furthermore, Derek Parfitt has outlined an analysis that leads to the conclusionthat, indeed, average utility 
cannot be the right criterion. Suppose a country has a population of 100 people, with an average measure of 100 happiness units If, to that country, we add a population with a lower average utility (but still, with lives worth living), would it make the situation better or worse? It would seem to make it better, as the original population is not aff cted, and the happiness units are increased. But, by doing this, average utility is decreased. If we keep on doing this procedure many times, we would reach a situation in which population size has increased, average utility has decreased, and we would believe this is in fact more desirable. In this case, a country (such as Bangladesh) with a huge popultion and lower living standards may actually be more desirable (provided all lives are worth living) than a country with very high standards (such as Norway) but with a smaller population. Parfi admitsthis conclusionis repugnant, but he is unclear about how it can be avoided, if at all. Th re really is no consensus about what the best ethicalcriterion is for the distribution of utility. See D. Parfi, Reasons and Persons (Oxford: Oxford University Press, 1986).

10 P. Rosanvallon, The Society of Equals, trans. A. Goldhammer (Cambridge, MA and London Harvard University Press, 2013).

11 Ths may have a biological basis. Most contemporary biologists give little weight to 'group selection' (i.e. altruism gives the group an advantage, and thus, it is selected for). In current discussions, genes foraltruism are assumed either to be mediated by reciprocity (we help those whom we expect to reciprocate) or kin selection (we help those who share a portion of our genes, i.e. relatives). However, some biologists, such as Wilson, off r considerable arguments in favour of group selection as the basis for altruism. See D. S. Wilson, Does Altruism Exist? Cultures, Genes, and the Welfare of Others (New Haven and London: Yale University Press, 2016). If he is right, then we may be biologically conditioned to make sacrifi es for the good of the group, regardless of kin proximity or expectation of eciprocity.

12 P. M. Kellstedt, S. Zahran and A. Vedlitz, 'Personal Effi cy, the Information Environment, and Attitudes Toward Global Warming and Climate Change in the United States', Risk Analysis, 28:1 (2008), pp. 113-26; S. Zahran, S. D. Brody, H. Grover and A. Vedlitz, 'Climate Change Vulnerability and Policy Support', Society and Natural Resources, 19:9 (2006), pp. 771-89; S. Zahran, S. D. Brody, A. Vedlitz, H. Grover and C. Miller, 'Vulnerability and Capacity: Explaining Local Commitment to Climate-Change Policy', Environment and Planning C: Government and Policy, 26:3 (2008), pp. 544-62.

13 D. Losurdo, Liberalism: A Counter-History, trans. G. Elliott London: Verso Books, 2014).

14 V. Papava, Necroeconomics: The Political Economy of Post-Communist Capitalism (Bloomington: IUniverse Inc., 2005).

15 Rawls, Theory of Justice.

16 R. Nozick, Anarchy, State, and Utopia (New York: Basic Bodks, 2013 [1974]).

17 T. Sowell, The Quest for Cosmic Justice (New York: Simon \& Schuster, 2001).

18 A. Martinisi and J. Lugo-Ocando, 'Overcoming the Objectivity of the Senses: Enhancing Journalism Practice through Eastern Philosophies', International Communication Gazette, 77:5 (2015), pp 439-55; J. Steel, Journalism and Free Speech (Abingdon: Routledge, 2013).

19 Th s may even have a basis in Aristotle's theories on catharsis in ancient Greek drama: when we watch tragedies on the stage, we are emotionally moved to act. Aristotle, Poetics, trans. M. Heath (New York: Penguin, 1997).

20 Th re is some neurological evidence that may support this claim. So-called 'mirror neurons' activate feelings of empathy when we observe others' suff ring. See C. Keysers, The Empathic Brain: How the Discovery of Mirror Neurons Changes Our Understanding of Human Nature (Bonn: Social Brain Press, 2011). 
21 For the former, see B. Höijer, 'TheDiscourse of Global Compassion: TheAudience and Media Reporting of Human Suff ring', Media, Culture and Society, 26:4 (2004), pp. 513-31;J. Petley, 'War WithoutDeath: Responses to Distant Suff ring', Journal for Crime, Conflict and the Media, 1:1(2003), pp. 72-85; I. B. Seu, “'Doing Denial”: Audience Reaction to Human Rights Appeals', Discourse and Society, 21:4 (2010), pp. 438-57. For the latter, see P. Robinson, The CNN Effect: The Myth of News, Foreign Policy and Intervention (Abingdon: Routledge, 2005); M. Shaw, Civil Society and Media in Global Crises: Representing Distant Violence (London: Continuum International/Pinter Publishers, 1996).

22 S. L. Carruthers, 'Media Constructions of "African Savagery" and "Western Humanitarianism" in the 1990s', in S. Allan and B. Zelizer (eds), Reporting War: Journalism in Wartime (Abingdon: Routledge, 2004), pp. 155-205; S. Franks, Reporting Disasters: Famine, Aid, Politics and the Media (London: Hurst Publishers, 2013).

23 I. Kant, Groundwork for the Metaphysics of Morals, ed. and trans. T. E. Hill, Jr. and A. Zweig (Oxford: Oxford University Press, 2003 [785]).

24 S. Cottl , 'Ulrich Beck, Risk Society and the Media: A Catastrophic View?' European Journal of Communication, B:1 (998), pp. 5-32.

25 U. Beck, Risk Society: Torwards a New Modernity, trans. M. Ritter (London, Thou and Oaks and New Delhi: Sage, 1992); P. L. Bernstein, Against the Gods: The Remarkable Story of Risk (New York: John Wiley, 1996); N. Luhmann, Risk: A Sociological Theory, trans. R. Barrett (New Brunswick and London: Transaction Publishers, 1998 [1993]); J. Rifkin, The Empathic Civilization: The Race to Global Consciousness in a World in Crisis (New York: Penguin, 2009).

26 A. Giddens and C. Pierson, Conversations with Anthony Giddens: Making Sense of Modernity (Cambridge: Polity Press, 1998).

27 Bernstein, Against the Gods; A. Giddens, Runaway World: How Globalisation is Reshaping Our Lives (London: Profile Books, 2011).

28 K. Polanyi, The Great Transformation: The Political and Economic Origins of Our Time (Boston: Beacon Press, 2002 [1944]).

29 Luhmann, Risk, p. 177.

30 Rawls, Theory of Justice.

31 Ths despite critics who believe that too much reliance on that safety net can hinder the commongood. See J. Harsanyi, 'Can the Maximin Principle Serve as a Basis for Morality? A Critique of John Rawls's Th ory', The American Political Science Review, 69:2 (1975), pp. 594 606. In that case, we would be rational not to desire too much protection for the least well off in society as to encourage them to work.

32 A. Sen, The Idea of Justice (London: Penguin, 2009).

$33 \mathrm{Th}$ re is also a case to be made about the more perverse interests of the narrativisation of suff ring. Ever since the end of the Cold War, and especially after the humanitarian crisis of Rwanda, national sovereignties have been weakened, and a growing international consensus, promoted by the United Nations, is tilting towards concepts such as 'Responsibility to Protect' (R2P). According to this view, there may be legitimate military interventions in order to stop humanitarian crisis. See A. J. Bellamy, Responsibility to Protect (Cambridge and Malden, MA: Polity Press, 2009). Th s rationale was used most notoriouslyin Kosovo, and more recently, Libya. However, there are critics who believe that this is nothing more than a refashionirg of old colonialist interventions, dressed in a humanitarian costume. Under this view, the narrativisation of suff ring is in fact a media strategy to serve imperial purposes. See P. Cunliff, Critical Perspectives on the Responsibility to Protect: Interrogating Theory and Practice (New York: Routledge, 2012). 
34 Moeller, Compassion Fatigue.

35 Chouliaraki, 'Post-Humanitarianism'.

36 N. Davies, Flat Earth News: An Award-Winning Reporter Exposes Falsehood, Distortion and Propaganda in the Global Media (London: RandomHouse, 2011); J. Lewis, A. Williams and B. Franklin, 'A Compromised Fourth Estate? UK News Journalism, Public Relations and News Sources', Journalism Studies, 9:1 (2008), pp. 1-20.

37 K. N. Kinnick D. M. Krugman and G. T. Cameron, 'Compassion Fatigue: Communication and Burnout toward Social Problems', Journalism \& Mass Communication Quarterly, 73:3 (1996), p. 687.

38 A. C. Burns, P. L. Gillett, M. Rubinstein and J. Gentry, 'An Exploratory Study of Lottery Playing, Gambling Addiction and Links to Compulive Consumption', Advances in Consumer Research, D (1990), p. 298.

39 S. Wolfson and P. Briggs, 'Locked into Gambling: Anticipatory Regret as a Motivator for Playing the National Lottery', Journal of Gambling Studies, 18:1 (2002), pp 1-17.

40 W. C. Adams, 'Whose Lives Count? TV Coverage of Natural Disasters', Journal of Communication, 36:2 (1986), pp. 113-22; G. D. Gaddy and E. Tanjong, 'Earthquake Coverage by the Western Press', Journal of Communication, 36:2 (1986), pp. 105-12; D. A. Van Belle, 'New York Times and Network TV News Coverage of Foreign Disasters: The Signific nce of the Insignific nt Variables', Journalism and Mass Communication Quarterly, 77:1 (2000), pp. 50-70.

41 L. Leibowitz and J. I. Krueger, 'Attitudes and Stereotypes about the Homeless: A Study on Self-Persuasion and Stereotype Accuracy', Journal of Social Distress and the Homeless, 14:3-4 (2005), pp. 125-50; J. Phelan, B. G. Link, R. E. Moore and A. Stueve, 'The Stigma of Homelessness: TheImpact of the Label "Homeless" on Attitudes Toward Poor Persons', Social Psychology Quarterly, 60:4 (1997), pp 323-37.

42 B. Duffy, 'Global Study Shows Many Around the World Uncomfortable with Levels of Immigration', Ipsos MORI (11 August 2016), www.ipsos-mori.com/researchpublications/ researcharchive/ 3771/ Global-study-shows-many-around-the-world-uncomfortable-withlevels-of-immigration.aspx. Accessed 15 July 2017.

43 M. Conboy, Journalism: A Critical History (London, Thou and Oaks and New Delhi: Sage, 2004); M. Deuze, 'What is Journalism? Professional Identity and Ideology of Joumalists Reconsidered', Journalism, 6:4 (2005), pp. 442-64; B. McNair, The Sociology of Journalism (Oxford: Oxford University Press, 1998).

44 S. Maras, Objectivity in Journalism (Cambridge: Polity Press, 2013).

45 Martinisi and Lugo-Ocando, 'Overcoming the Objectivity of the Senses', p. 453.

46 K. V. Kortenkamp and B. Basten, 'Environmental Science in the Media: Eff cts of Opposing Viewpoints on Risk and Uncertainty Perceptions', Science Communication, 37:3 (2015), p. 287.

47 T. Hirschl, M. Rank and D. Kusi-Appouh, 'Ideology and the Experience of Poverty Risk: Views About Poverty within a Focus Group Design', Journal of Poverty, 15:3 (2011), pp. 350-70.

48 Martinisi and Lugo-Ocando, 'Overcoming the Objectivity of the Senses', p. 440.

\section{References}

Adams, W. C., 'Whose Lives Count? TV Coverage of Natural Disasters', Journal of Communication, $36: 2$ (1986), pp. 113-22.

Aristotle, Poetics, trans. M. Heath (New York: Penguin, 1997). 
Beck, U., Risk Society: Torwards a New Modernity, trans. M. Ritter (London, Thou and Oaks and New Delhi: Sage, 1992).

Bellamy, A. J., Responsibility to Protect (Cambridge and Malden, MA: Polity Press, 2009).

Bernstein, P. L., Against the Gods: The Remarkable Story of Risk (New York: John Wiley, 1996).

Boltanski, L., Distant Suffering: Morality, Media and Politics, trans. G. D. Burchell (Cambridge: Cambridge University Press, 1999).

Burns, A. C., P. L. Gillett, M. Rubinstein and J. Gentry, 'An Exploratory Study of Lottery Playing, Gambling Addiction and Links to Compulive Consumption', Advances in Consumer Research, D (1990), pp. 298-305.

Carruthers, S. L., 'Media Constructions of "African Savagery" and "Western Humanitarianism" in the 1990s', in S. Allan and B. Zelizer (eds), Reporting War: Journalism in Wartime (Abingdon: Routledge, 2004), pp. 155-205.

Chouliaraki, L., 'Post-Humanitarianism: Humanitarian Communication beyonda Politics of Pity', International Journal of Cultural Studies, B:2 (2010), pp. 107-26.

Chouliaraki, L., The Ironic Spectator: Solidarity in the Age of Post-Humanitarianism (Cambridge: Polity Press, 2013).

Conboy, M., Journalism: A Critical History (London, Thou and Oaks and New Delhi: Sage, 2004).

Cottl , S., 'Ulrich Beck, Risk Society'and the Media A Catastrophic View?' European Journal of Communication, B:1 (998), pp. 5-32.

Cunliff , P., Critical Perspectives on the Responsibility to Protect: Interrogating Theory and Practice (New York: Routledge, 2012).

Davies, N., Flat Earth News: An Award-Winning Reporter Exposes Falsehood, Distortion and Propaganda in the Global Media (London: Random House, 2011).

Dayan, D. and E. Katz, Media Events: The Live Broadcasting of History (Cambridge, MA: Harvard University Press, 1994).

Debord, G., The Society of the Spectacle, trans. D. Nicholson-Smith (New York: Zone Books, 1994 [1967]).

Deuze, M., 'What is Joumalism? Professional Identity and Ideology of Journalists Reconsidered', Journalism, 6:4 (2005), pp 442-64.

Duffy, B., 'Global Study Shows Many Around the World Uncomfortable with Levels of Immigration', Ipsos MORI (11 August 2016), www.ipsos-mori.com/researchpublications/ researcharchive/ 3771/Global-study-shows-many-around-the-world-uncomfortable-withlevels-of-immigration.aspx. Accessed 15 July 2017.

Easterly, W., The White Man's Burden: Why the West's Efforts to Aid the Rest Have Done So Much Ill and So Little Good (London: Penguin,2006).

Franks, S., Reporting Disasters: Famine, Aid, Politics and the Media (London: Hurst Publishers, 2013).

Gaddy, G. D. and E. Tanjong, 'Earthquake Coverage by the Western Press', Journal of Communication, 36:2 (1986), pp. 105-12.

Giddens, A., Runaway World: How Globalisation is Reshaping Our Lives (London: Profile Books, 2011).

Giddens, A. and C. Pierson, Conversations with Anthony Giddens: Making Sense of Modernity (Cambridge: Polity Press, 1998).

Harsanyi, J., 'Can the MaximinPrinciple Serve as a Basis for Morality? A Critique of John Rawls's Th ory', The American Political Science Review, 69:2 (1975), pp 594-606.

Hirschl, T., M. Rank and D. Kusi-Appouh, 'Ideology and the Experience of Poverty Risk: Views About Poverty within a focus Group Design', Journal of Poverty, 15:3 (2011), pp 350-70.

Höijer, B., 'TheDiscourse of Global Compassion: TheAudience and Media Reporting of Human Suff ring', Media, Culture and Society, 26:4 (2004), pp. 513-31. 
Kant, I., Groundwork for the Metaphysics of Morals, ed. and trans. T. E. Hill, Jr. and A. Zweig (Oxford: Oxford University Press, 2003 [D85]).

Kauffman, W. A., Nietzsche: Philosopher, Psychologist, Antichrist (Princeton: Princeton University Press, 2008).

Kellstedt, P. M., S. Zahran and A. Vedlitz, 'Personal Effi cy, the Information Environment, and Attitudes Toward Global Warming and Climate Change in the United States', Risk Analysis, 28:1 (2008), pp. 113-26.

Keysers, C., The Empathic Brain: How the Discovery of Mirror Neurons Changes Our Understanding of Human Nature (Bonn: Social Brain Press, 2011).

Kinnick K. N., D. M. Krugman and G. T. Cameron, 'Compassion Fatigue: Communication and Burnout toward Social Problems', Journalism \& Mass Communication Quarterly, 73:3(1996), pp. 687-707.

Kortenkamp, K. V. and B. Basten, 'Environmental Science in the Media: Eff cts of Opposing Viewpoints on Risk and Uncertainty Perceptions', Science Communication, 37:3 (2015), pp. $287-313$

Leibowitz, L. and J. I. Krueger, 'Attitudes and Stereotypes about the Homeless: A Study on SelfPersuasion and Stereotype Accuracy', Journal of Social Distress and the Homeless, 14:3-4 (2005), pp 25-50.

Lewis, J., A. Williams and B. Franklin, 'A Compromised Fourth Estate? UK News Journalism, Public Relations and News Sources', Journalism Studies, 9:1 (2008), pp. 1-20.

Losurdo, D., Liberalism: A Counter-History, trans. G. Elliott London: Verso Books, 2014).

Lugo-Ocando, J., Blaming the Victim: How Global Journalism Fails Those in Poverty (London: Pluto Press, 2014).

Luhmann, N., Risk: A Sociological Theory, trans. R. Barrett (New Brunswick and London Transaction Publishers, 1998 [1993]).

Maras, S., Objectivity in Journalism (Cambridge: Polity Press, 2013).

Martinisi, A. and J. Lugo-Ocando, 'Overcoming the Objectivity of the Senses: Enhancing Journalism Practice through Eastern Philosophies', International Communication Gazette, 77:5 (2015), pp 439-55.

McNair, B., The Sociology of Journalism (Oxford: Oxford University Press, 1998).

Moeller, S. D., Compassion Fatigue: How the Media Sell Disease, Famine, War and Death (New York and Abingdon: Routledge, 1999).

Nozick, R., Anarchy, State, and Utopia (New York: Basic Bodks, 2013 [1974]).

Papava, V., Necroeconomics: The Political Economy of Post-Communist Capitalism (Bloomington: IUniverse Inc., 2005).

Parfi, D., Reasons and Persons (Oxford: Oxford University Press, 1986).

Petley, J., 'War WithoutDeath: Responses to Distant Suff ring', Journal for Crime, Conflict and the Media, 1:1 (D03), pp 72-85.

Phelan, J., B. G. Link, R. E. Moore and A. Stueve, 'The Stigma of Homelessness: The Impact of the Label "Homeless" on Attitudes Toward Poor Persons', Social Psychology Quarterly, 60:4 (1997), pp 323-37.

Polanyi, K., The Great Transformation: The Political and Economic Origins of Our Time (Boston: Beacon Press, 2002 [1944]).

Rawls, J., A Theory of Justice (Cambridge, MA.: Harvard University Press, 1971).

Rifkin, J., The Empathic Civilization: The Race to Global Consciousness in a World in Crisis (New York: Penguin,2009).

Robinson, P., The CNN Effect: The Myth of News, Foreign Policy and Intervention (Abingdon: Routledge, 2005). 
Rosanvallon, P., The Society of Equals, trans. A. Goldhammer (Cambridge, MA and London Harvard University Press, 2013).

Seaton, J., Carnage and the Media: The Making and Breaking of News about Violence (London: Allen Lane, 2005).

Sen, A, The Idea of Justice (London: Penguin, 2009).

Seu, I. B., '"Doing Denial”: Audience Reaction to Human Rights Appeals', Discourse and Society, 21:4 (2010), pp. 438-57.

Shaw, M., Civil Society and Media in Global Crises: Representing Distant Violence (London Continuum hternational/ Pinter Publishers, 1996).

Sowell, T., The Quest for Cosmic Justice (New York: Simon \& Schuster, 2001).

Steel, J., Journalism and Free Speech (Abingdon: Routledge, 2013).

Van Belle, D. A., 'New York Times and Network TV News Coverage of Foreign Disasters: The Signific nce of the Insignific nt Variables', Journalism and Mass Communication Quarterly, 77:1 (2000), pp. 50-70.

Wilson, D. S., Does Altruism Exist? Cultures, Genes, and the Welfare of Others (New Haven and London: Yale University Press, 2016).

Wolfson, S. and P. Briggs, 'Locked into Gambling: Anticipatory Regret as a Motivator for Playing the National Lottery', Journal of Gambling Studies, 18:1 (2002), pp. 1-17.

Zahran, S., S. D. Brody, H. Grover and A. Vedlitz, 'Climate Change Vulnerability and Policy Support', Society and Natural Resources, 19:9 (2006), pp. 771-89.

Zahran, S., S. D. Brody, A. Vedlitz, H. Grover and C. Miller, 'Vulnerability andCapacity: Explaining Local Commitment to Climate-Change Policy', Environment and Planning C: Government and Policy, 26:3 (2008), pp. 544-62. 


\section{Part IV}

Capitalism, consumption and charity 



\title{
10
}

\section{Consumption, global humanitarianism and childhood}

\author{
Laura Suski
}

The notion of political consumption suggests that our everyday practices of consumption are ethicalpractices. It may be argued that these ethicalpractices become more important when children are involved as it is often argued that our ethical obligations to children require protection and care. As political consumers, we might seek actions such as protecting 'our' children by purchasing environmentally friendly products, or we might act against child labour practices in 'distant' nations by purchasing garments manufactured by particular companies. Th se practices raise several questions of a global humanitarianism for children. Can the intent to protect 'our' children extend to a more universalised impuke to protect 'other', more distant children? What are the limitations of political consumerism as a channel for a humanitarian impule? Can the everyday practice of consumption be a space of care and concern for international justice?

In this chapter, I bring these questions to the analysis of the consumption of children's toys and the online discussions of boycotting 'unsafe' toys. I explore how a neoliberal parenting culture in the West, which promotes a highly individualised and intensive model of parenting, aff cts a more universal and collective call for a global international humanitarianism. While social media provides opportunities to share and discuss information about toy safety, it will be argued that emotion is an important part of humanitarian mobilisation, and that the emotions of consumption are often thwarted by the identity politics of consumption.

\section{Distance, care and the political consumer}

Thelandscape ofcontemporary consumption practices includes practices considered 'ethical responses to the myriad of problems that have come to mark global consumption. Political consumption recognises the power of consumers to use their spending power to alter such things as the labour relations behind products, the 'green' or organic content of products, the health of local economies, the safety of products and the treatment of animals in the production process. Thevaried spaces 
of political consumerism make it very difficult to draw parallels between forms of political consumption like boycotting, the refusal to buy certain products, and buycotting, choosing to support one product over another. What, for example, is the relationship between the consumer who purchases carbon offsets for her recent flight to Greece, and the consumer who purchases second-hand clothes at the local thrift store?' Political consumerism may also be gendered in that women and men may be aff cted by diff rent factors including levels of trust in organisations and corporations. ${ }^{2}$ Moreover, while political consumerism can be used to create more ethicalconsumption, it can also be a tool to support nationalism, intolerance, exclusiveness, or other types of hatred. ${ }^{3}$

A recurrent theme in the analysis of ethical consumption is the claim, or worry, 'that it refl cts a substitution of publicly oriented collective participation by identitybased, individually motivated and privatized forms of concern.". Th s theme is made more acute if we are asking consumers to think about global collectivities. As Jo Littl r points out, certainversions of anti-consumerism can lead to a 'quasi-pathology of consumerism heroism' and to 'more individualized solutions than the modes of consumption that they critique. ${ }^{5}$ Global ethicists have always had to contend with the question of how far our ethical obligations extend, and whether such obligations could ever trump obligations to those closest to us. In the early 1970s, utilitarian philosopher Peter Singer asked what our obligations might be to distant suff rers of famine Acknowledging that we fi st have responsibilities to our family, he personally practised the maxim that we shouldmove to channel our personal surpluses to those who need it anywhere in the world, and in this sense we should 'give until it hurts.' 6 For Singer, the utilitarian maxim is transportable in that we must look beyond the needs of our own society. Adam Smith (1759) raised the question of indiff rence for the suff ring of distant others in his eighteenth-century work The Theory of Moral Sentiments. Asking his readers to compare the experience of losirg a little finger to an earthquale in China, he presented the model of an inner impartial spectator that was capable of a form of reasonable sym pathy that was both mobile and capable of moving men out of self-love. Given the profound difficulty of traversing diff rences in geography and privilege, it makes sense that Adam Smith was absorbed by sympathetic identific tion as critical to his eighteenth-century model of the impartial spectator. Cosmopditan sentiments, however, can be highly sentimentalised and problematic. As Sonia Bookman points out in her analysis of contemporary emotional branding and the urban 'consumptionscape' of coff e, everyday consumers of coff e build their own aff ctive experiences of coff e where the "love of coff e is extended to a "care" for coff e origins. ${ }^{3}$ In essence, she suggests, the coff e consumer is able to 'do good' through cosmopolitan branding because he or she gets to act out feelings of care and empathy, and in tun, gain moe pleasure in the onsuming activity.

One might argue that today's consumer may not need to work very hard to feel connected to distant issues. Sites such as 'sweatfreeshop.com' provide resources for shoppers to avoid problematic brands. Personal blogs dedicated to minimalism and 
ecofriendly living can also direct people to local fashionbrands. If such information is readily available to those who Google, or follow blogs, Twitter or Facebook feeds, it begs the question if one may even need sympathetic identific tion to connect with distant strangers? Faced with the facts of problematic consumption, won't the global consumer who is inclined towards ethicalconsumption simply make reasonable decisions about what to consume, particularly if such facts are delivered by a Facebook friend or a curated newsfeed?

Discussing the case of a wave of sit-ins and protests by the indignados to the economiccrisis in Spainin 2011, Paolo Gerbaudorefers to a 'harvesting of indignation' by social media like Facebook and Twitter, and explores how such media 'contributed to transforming individual sentiments of anger into a collective identity animated by a desire to take back the streets after years of demobilisation. ${ }^{9}$ Gerbaudo insists that we not see social media in purely 'cognitivist' way as a 'network of brains', and rather, argues for the need to 'recuperate a sense of the body and the emotions in the process of contemporary mobilisation. ${ }^{10}$ As he examines variousmovements of 2011, including the Arab Spring, he stresses the 'emotional coalescence of the people' and refuses to see social media as merely an informational conduit.1

My focus in this chapter, and indeed in my other work around humanitarianism, is the emotional and social character of humanitarianism. ${ }^{12} \mathrm{I}$ argue that it is important to see humanitarianism as a social configuration of moral actors, and to see that social configuration as embedded in a politics of emotion. In her compelling history of human rights, Lynn Hunt argues, the claim that human rights are 'self-evident' relies on an 'emotional appeal' because 'it is convincing if it strikes a chord with each person. ${ }^{13}$ Global humanitarianism requires a breaking down of distance between humanitarians and so-called victims and emotion plays a large role in breaking down this distance.

On the question of consumer action, we can see an intersection in debates in the scholarships around online activism and global humanitarianism. While it is true that global capitalism makes possible material connections between consumers, and while we can be informed of these connections more quickly and easily through digital networks, these connections do not fully explain why we respond to some calls for action and not others. We need to further unpack the sentiments that mobilise humanitarian action. An exploration of political consumption and childhood off rs a window into the complex space of humanitarian mobilisation.

\section{Toys and the consumption of childhood}

While many have challenged historian Phillippe Ariès' confid nt claim that childhood was a 'modern invention', scholars have described an important shift in the understanding and the experience of childhood that took place with the spread of industrialisation, and the accompanying movement away from childhood as a period of labour: childhood became a period of innocence and play. ${ }^{14}$ Toys became 
part of this shift in that they affirmed childhood as a uniqueperiod in the life course, and middle-class homes soon sought out toys to affirm this ideal childhood. ${ }^{15}$ Researchers of consumption see children as occupying an important frontier for capitalist expansion ${ }^{16}$ Childhood play has become fully 'capitalised' and children fully socialised as consumers, evidenced by such trends as the intersection of entertainment and merchandising, and by toys that necessitate collecting and cumulative consumption. Child-centred, open-ended imaginative play has been replaced by toys that limit play possibilities and necessitate consumption on the part of the child. ${ }^{17}$ In the spirit of work like Juliet Schor's Born to Buy (2004), childhood is a site where excessive consumption is intensifi $\mathrm{d}$ through a socialisation that occurs in the market. ${ }^{18}$ As Langer notes, at the end of the twenty-fi st century children's consumption works to re-inscribe children as 'sacred', this time due to theirspending power. ${ }^{19}$

While it is clear that childhood takes place in the world of consumption, and that the market is implicated in the 'psychic formation of the child', there is much disagreement as to what this means for the consuming child. ${ }^{20}$ Despite the presence of childhood in many theories of consumerism, I concur with Daniel Tho as Cook's claim that such theories 'do not know childhood' and that most discussions of consumption have failed to provide a thorough account of the economiclife of children. ${ }^{21}$ For example, classic sociological theorists of taste and consumption, such as Pierre Bourdieu, do not provide a serious treatment of children. ${ }^{22} \mathrm{Few}$ contemporary theorists of consumption draw directly on accounts of the social lives of children, nor the cultural histories of childhood ${ }^{23}$ Cook argues that we need to move beyond seeing the individual child as an independent economicactor, to a theory of consumption whichsees contemporary children as participating in a social world in which they are already embedded as consumers, and that purchasing often 'takes place, for, in the name of, or with someone in mindother than the shopper. ${ }^{24} \mathrm{Cook}$ insists that children call into question the individuality of desire, identity, and lifestyle. ${ }^{25}$

The analysis of childhood consumption is also aff cted by the use of models of identity to understand consumption. An added analytical difficulty is that we are often presented with dichotomous models of shopping where the consumer is either an 'enraptured pleasure seeker' or a 'relationally constrained actor locked into a series of actions. ${ }^{26}$ Sociologist Zygmunt Bauman is wary of the identity politics of consumption where a fully commodfi $\mathrm{d}$ self replaces the citizen, and where mass consumption is affirmed as the only economicfoundation of society. ${ }^{27} \mathrm{Th}$ s debate dovetails neatlywith discussions about'new' and 'old' models of childhoodsocialisation. Where psychological and sociologicaltheories of childhood development once saw the child as a passive sponge who simply absorbed socialisation, more recent theories see the child as an empowered agent in theirown becoming. ${ }^{28}$ Mapped onto the analysis of consumption, this dichotomous reading of childhood development sees children as either exploited and manipubted consumers (along with the rest of us), or active agents in their own identity building through consumption. 
Th re are, however, answers to the impasse around consumer identity. As Dennis Soron argues in his discussion of sustainable consumption, there are promising ways to bring self-identity 'back in' without succumbing to a mere celebration of consumption, nor an overly individualist account of how consumer agency operates. He argues that we need to pay due attention to the ambivalent role of consumption in our daily lives: 'exploring the intersection of sustainable consumption and self-identity requires us to comprehend the constrained context and political limits of individual "green" lifestyle choices even as we engage sympathetically with the ethical and collectivist impulses underlying them.'. Again, Soron is clear that in approaching sustainable consumption through the analysis of identity we must continue to aim for 'reconstituting a social, collective and non-commodified basis for personal identity. ${ }^{30}$

If we take Cook's suggestion that we need to look at the social lives of children and move beyond the notion of children as independent economicactors, then it seems we should explore toy buying as part of parenting (noting, of course, that many children are active consumers in their own right). A key line running through Vivian Zelizer's book The Purchase of Intimacy (2005) is that we take the relationship between economics and intimacy seriouslyand see household economics as a social process through which household relationships are constructed. ${ }^{31}$ As Charlotte Faircloth also insists, contemporary parenting is a project of identity work: 'In deciding how to dress, feed, put to sleep and transport their children, adults do not simply live their lives through children but, in part, develop their own identity through them. ${ }^{32}$ Thus, toy consumption can be seen as a space where the identity of parent is also constructed.

Privileged parents buying toys certainly occupy a unique space of consumer agency in that they no doubt experience some of the ambivalences around consumption as they both seek to provide a childhood of innocence and play for their children, while at the same time perhaps try to think ethically about how to provide this kind of childhood. One of the key aspects of the social lives of privileged children is the current dominance of a model of intensive parenting. According to scholars of childhood, this model of parenting mainlyapplies to privileged women as primary caregivers and suggests that mothers are to invest large amounts of time, moneyand energy into parenting, and that they shouldgather expert knowledge to build their parenting repertoire. ${ }^{33}$ Intensive parenting is also accompanied by what some call 'parental determinism' in which it is the parent alone who is considered responsible for the wellbeing and socialisation of the child, and in turn, the child is considered a product of parenting. ${ }^{34}$ In intensive parenting, the moral view is entirely parent to child, in particular, the mother to child relationship. As Glenda Wall notes, the intensific tion of parenting is wrapped up in a neoliberal logic which emphasises individual self-management and control. ${ }^{35}$ Intensive parenting also includes protecting children from risks, and the list of risks is ever increasing, even including parents as risk factors themselves. ${ }^{36}$ Given that it is promoted as an ideal 
form' of mothering, those mothers who are unable to follow the model, like lowincome mothes, can view intensive mothering as enforced and coercive. ${ }^{37}$

More recently, there has been some backlash against this model and greater discussion of the 'over protected child. Joumalist Lenore Skenazy, for example, has popularised the idea of 'free range parenting' where parents are encouraged to allow theirchildren to take more risks and to resist the idea that theirkids occupy a world of constant danger and threat. Frank Furedi's 2008 Paranoid Parenting, as another example, encourages parents to ignore the experts. Still, given that the model powerfully intersects with a popular embrace of the idea of a 'risk society', the individualisation upheld in neoliberalism, and the cultural approach to childhood as a period of innocence, contemporary parenting is still marked by the assumption that children demand constant protection by parents.

Toy consumption occurs in a particular kind of moral community that involves an intersection of parenting and consumption. Some buycotts and boycotts have successfully produced moral communities that join localised consumers with distant producers, and in tum, have contributed to initiatives to improve labour conditions for workers and more sustainable forms of production. However, due to the natures of contemporary childhood and parenting, toy consumption often works to separate and alienate consumers from producers, rather than bringing them into co-operation or connection. Themoral economies of Western childhood that see children as vulnerable subjects in a society of risk and, in turn, in need of care and protection, can come into conflict with the moral economies of global consumption that require consumers to expand theirmoral vision. In short, the general push is often to protect children from the dangers of global consumption, rather than to bring them into a moral community that seeks to make social and political connections between so-called distant strangers. Still, I concludethat it is important to look at the example of toy consumption as it deepens the analysis of consumption and childhood, challenges idealised or romanticised notions of a global moral community, and allows for further exploration of consumption as a site of global citizenship.

How do toy consumers feel and care about the producers of the toys who are most often making toys in other 'distant' parts of the world? The case of a 2007 toy recall of a popular toy train series off rs some preliminary insights. 'Tho as and Friends Wooden Railway Toys' is a series of trains made of wood and plastic, based on an early twentieth-century book series, and later developed into a television series in the 1970s. Theyare expensive toys; current prices for individualtrains range from $\$ 15$ to $\$ 30$ Canadian dollars. The toys tend to be played with by younger children with the suggested age range being 2-7 years old. In 2007, RC2, the company that made the internationally popular children's wooden train toys, recalled 1.5 million units as a result of the 'discovery' of lead-based paint in the trains. ${ }^{38}$ Most of the recalled units used red paint and all were manufactured in China. Consumers were told to send the trains back to receive a replacement. Ths recall came amongst a series of 
productrecalls in China, including cases of tainted pet food, milk and toothpaste. In fact, a recent book, Not Just China, described 2007 as the 'year of the recall.39 Other toy manufacturers like Mattel and Fisher Price were also embroiled in recalls that same year.

It is no doubt that the use of lead paint makes a toy a more dangerous plaything, particularly if flakes of lead paint are ingested. The WHO confi ms that ingested lead can have dangerous impacts on the developing brains of young children, and even low levels can have neurological eff cts. Th re are a number of factors that contribute to higher concern for lead poisoning in children, including the fact that children absorb lead at greater rates than adults. While there are no safe levels of lead, it is difficult to assess the amount of risk involved with lead-painted toys, including the likelihood of paint being ingested and the amount of paint that wouldbe needed to cause serioushealth concerns, particularly given that the eff cts of lead are cumulative. Th re is little evidence to suggest that the toys themselves caused health consequences, and in tun, that the recall is more of a cas of a lead panic.' ${ }^{40}$

When the dangers of lead became known, many countries adopted legislation to limitthe use oflead in consumer productsand the environment. Lead gas and household lead paint, for example, is considered hazardous and it is no longer available in many countries around the world. Like most environmental risk stemming from the production of good, the dangers are greatest in the global South and amongst the poor: according to the WHO about one half of the burden of disease from lead occurs in the South-East Asia Region, with about one-fifth each in the Western Pacific and Eastern Mediterranean Regions. In addition to children, workers are at great risk due to continued, cumulative exposure. Workers who work with leaded paint, for example, can also bring it home to their families on their clothes in the form of dust. In North America, lead poisoning risks remain, particularly around older homes with deteriorating paint and increased dust.

How did parents respond to these recalls? If online conversations, parenting blogs and online comments sections are used as data, the overwhelming reactions were shock, anger and fear. One New York Times article quoted a mother discussing her son's attachment to the toys and her disappointment with the ecall:

Th se are the kinds of things he takes to bed with him. He putsthem in his pocket and he takes them to the store, he takes them in the car - everywhere ... You thinkthat when you're buying a high-end toy like a Tho as the Tank Engine train, that you're getting something that has gone through all the proper channels to make sure it's a safe toy.

Another parenting blog responded with equivalent shock but ado with annoyance:

I am utterly shocked that our consumer protection agency even allows these products imported into our country since we've known about the dangers of lead poisoning 
for $30+$ years. I am a working momand additionally angry that I have to take the time to remove and replace these items and check for any poisoning in my children. I will sign a petition to ban any imported children's products that do not meet our own standards. Next time, buy german toys $!^{41}$

As parents who had purchased Tho as and Friends merchandise expressed fear and anger about the recall, some who had not purchased the toys took the opportunity to remindparents about the problems of mass-produced toys more generally. Comments to a Washington Post article includel the fdlowing statement:

My 4-year-old has a drum kit, a group of stuff $\mathrm{d}$ animals, and a lot of outdoor toys (jumprope, bouncy ball, sidewalk chalk). I prefer her to use her imagination than have the toy companies imagine stuff at her, but now I have another level to be smug about.

Many respondents directed their outrage at the government for not protecting the interests and safety of their children; however, China and Chinese products also becamevilifi d in the media. China was 'not to be trusted' and the general parenting lesson to be emphasised was that toys from China were to be avoided.

Amidst the mass of comments that spoke with anger that North American consumers should not have to worry about dangerous toys, there were a few voices that raised diff rent concerns. For example, in response to an online discussion that included some anti-Chinese comments about the recall, one commentator noted: 'It's silly to blame this on China, and turn it into a question of nationalism. The company is American and listed on NASDAQ! Unless the lead paint was a conspiracy sponsored by the Chinese government with the goal of poisoning the youth of America through toys, try a diff rent, valid argument to express your upset.' ${ }^{2}$

It makes sense that the fi st reaction of parents was to protect their children from harm, but why did it stop there? Why didn't any parents express concern about the workers who had to make such 'hazardous' toys or the communities that might be aff cted by increased exposure to lead paint? Why were consumers seemingly unable to expand their moral communities so as to thinkof themselves as part of a chain of production and consumption, as in other practices of ethical consumption? From this particular recall, no larger initiative of political consumerism seemed to emerge to eliminate the use of lead paint in countries around the world or to encourage better labourconditions. Nor did the recall seem to trigger an attempt to increase awareness about lead poisoning in the global North. No online petition was circulated by parents, and surprisingly, no initative to fomally boycott the ompany emerged.

The HIT company which owned Tho as the Train was not severely fi ancially aff cted by the recall, though it reported losses in 2009. The company was later bought out by Mattel in 2011 for $\$ 680$ million. ${ }^{43}$ Most consumers seemed to return the specifica ly recalled trains with enough faithin the company that they felt assured that this would not happen again, and that they had eff ctively managed the 
risk. If, as consumer theory suggests, we can be 'attached to commodties in deeply ingrained, aff ctively charged ways', consumers seemed certainlyattached to Tho as and Friends. ${ }^{44}$ Therecall had impacted the sacred space of play and perhaps the key goal was simply to return play to an original state of innocence and joy. In this case, the feelings of anger and distrust that parents experienced did not function as moral emotions in that they did not work to fuel somekind of global ethicalconnection or some cosmopolitan feeling.

No doubt the fact that China is seen as an impenetrable nation where consumers can do little about the politics of production is responsible in part for a lack of discussion and concern amongst parents for the producers of the lead-painted trains. Consumers need to feel as if theiractions will have an impact in order to feel motivated to act. ${ }^{45}$ Many consumers felt as if China and Chinese citizens have willingly accepted the risks that accompany the production of cheap goods. Moreover, this recall was one amongst many and consumers probably felt that a buycott or boycott would be futile. One key diff rence from other recalls at the time, however, was that Tho as and Friends made high-end toys that many parents assumed to be safe due to the price of the toys. Affl nt North American mothers engaged in a practice of intensifi d parenting likely viewed the Tho as the Train recall as an affront to the already difficult task of parenting in a society of risk. Further, as Wall points out, the 1990s saw a rise in the discussion of parents as the builders of children's brains. ${ }^{46}$ One can only assume that the potential of lead poisoning would have been a doube affront in this sense.

The space of child's play may be also an impenetrable moral space in that it is highly guarded by parents themselves. Products like organic baby food or hemp clothes have little difficulty penetrating the insular parent-child relationship of intensive parenting as they promise increased safety and health for children, but other forms of political consumerism have a more difficult road. ${ }^{47}$ While intensive parenting seems a likely discourse for extending the moral vision of parents through empathetic identific tion with distant others, instead, the impetus seems to be for good parenting, not good collective citizenship. When parenting is consistently raised as the cause of all social ills, it is not that parents are accused of ignoring their roles as public citizens, but rather, that 'bad parents' are ignoring or failing at their role of raising future good citizens. One of the most serious problems of intensive parenting is that it is often a highlysolitary process in that the parent themselves must know the child inside and out, and must act as the sole moral agent on the behalf of the child. Th s can breed distrust if parents become less and less able to trust other adultsin the task of socialising the next generation. ${ }^{48}$ As one mother noted after the recall: 'That's the scariest thing, because now it makes me want to go out and test all their toys because ... I don't trust any of them.' While Arlie Hochschild's important work on emotional labour focused on the costs of emotional regulation in labour, her general lesson that emotional regulation comes with its costs is relevant; one of the emotional costs of intensive mothering may be the heavy burden of the constant regulation of worry and risk. ${ }^{49}$ 
Mel Y. Chen argues that 'lead stories' also require attention to race. The 'lead panics' of 2007, Chen notes, centred aroundimages of vulnerable white middle-class children playing with suspect toys. While the company took legal responsibility for the recall, it was China that became the site of attention and blame. The apparent global movement of toxic lead emphasised 'its mobility through and against imperialistic spatializations of "here" and "there" ${ }^{50}$ Chen notes that the new lead paniccan be understood in the discourse of 'contagion' which echoes a 'turn-of-the-century Orientalized threat to white domesticity'; parents, therefore, were guarding against not only the threat of lead, but voicing a concern for a vulnerable 'national body. ${ }^{51}$ As Chen also points out, the image of a vulnerable white child is promoted while the ongoing exposure of people of colour to risk is ignored: 'An environmental history of toxic objects must minimally register the gendered, laboring, and chronically toxically exposed bodies of globalized capital, which systematically bear less frequent mention in narratives of toxicity than the cautionary warnings from the seat of US empire. ${ }^{52}$ Chen's analysis encourages us to thinkcarefully about the dangers of parenting narratives of protection, as such narratives can easily extend into nationalist narratives. Moreover, against the history of colonialism and empire, the global South becomes a reminder of unsafe versions of childhood that the global North has progressed beyond, and in tun, the connection is made that much harder.

If the space of political consumerism and toys demonstrates clashing narratives of parenthood, the tragic photographs of Alan Kurdi, a drowned Syrian boy, which circulated online in the fall of 2015 , may off $r$ a more unifi $d$ narrative of parenting. Thephotographs were uniquein theirability to galvanise concern forSyrian refugees in many parts of the world. It was a surprising galvanisation given that the photograph broke the powerful taboo of presenting a dead child in mainstream media. Thetaboo was even broken in headlines like the New York Times story (2 September 2015) that proclaimed 'A dead baby becomes the most tragic symbol yet of the Mediterranean refugee crisis'. In response to the New York Times story, one online reader simply articulated: 'I cried. I just cried. What are we?' While some viewers were not ready for suchimages, others saw the merits in publishing the photographs and were moved to action. How did these particular photographs move viewers, while hundreds of other photographs of refugees seemed to lead to indiff rence? One possible reason is that Alan Kurdi was an innocent victim who people could easily identify with, and who could easily be absorbed into a parenting narrative of cosmopolitan caring. He wore clothes that most parents in the West could recognise, and the beach on which his body lay seemed like a beach that anyone might visit on holiday. One comment on a Huffington Post story (2 September 2015) urges those engaged in the online debate to 'imagine themselves a parent to that child. The protection of Alan Kurdi (and future Alan Kurdis) was not positioned as coming at the expense of the protection of children in the West. If anything, the tiny child in a red T-shirt and running shoes was already a child of the West in the eyes of many viewers. In Canada, Alan Kurdi became the call to increase the number of Syrian 
refugees, or put diff rently, to make him and others children of Canada. ${ }^{53}$ Th s kind of narrative is used successfully by many international NGOs, particularly those that employ a child sponsorship model. Donors are essentially engaged in restoring lost childhoods. $^{54}$

Th re is a larger question haunting my analysis: does parenting a child make parents betterglobalcitizens? Th re is noeasy answer to this question. Erika Languir's compelling art history of childhood, Imagining Childhood, off rs us an important refl ction in its concluding line that images in the Western tradition have 'always made plain that we are all childlike. ${ }^{55}$ Our ethical encounter with our own children is always an ethicalencounter with our own childhoods. If contemporary parenting cultures turn us inwards, and if political consumption leads to individualised identity politics, these inward turns may be more accentuated by the fact that the often unstable category of childhood is constructed by parents themselves. The inward push may be an obstacle for the apparent requirement of an outward pull for global humanitarian activism. Still, we can recognise this challenge. Jo Littl $r$ highlights the 'interior economies' of radical consumption politics and notes that we need to think more deeply about the models of 'refle ivity' that lead to activism. ${ }^{56}$ While she sees promise in tools off red by cultural studies, she also recognises the need to move into 'wider' and more 'messy' terrain to explore how 'alternative economies elicit aff ctual investments (or not)'. ${ }^{57}$ Thus, to understand how and when media cultures support a global humanitarianism for distant children, our theoretical tools must includethose that can unpack parenting culture, and the emotional economies that govern this culture.

\section{Conclusion}

When children are mentioned in reference to issues of inequality, it is often through the very possessive claim 'our children', implying that there are other people's children that are not of 'our' concern. Interestingly, the moral claims we make in the name of children often seek to stabilise them as moral subjects, as vulnerable and at risk. In the case of the toy train recall, there was a clear sense that midde-class and wealthy children could be protected from the risks that other children experience. The intensific tion of modern parenting is deeply at odds with a mode of ethical consumption that requires that moral distance be overcome. Gaining knowledge of the working lives of others becomes even more difficult if we are witnessing a model of parenting that embraces a neoliberal, individualised notion of chld as poduct.

If we are to understand how ethical consumption is practised and whether it holds promise as a way to shift from the individual to the collective, we cannot simply speak of connection as an abstract principle, and we cannot think of social media as simply erasing distance. Instead, we must see consumption practices as enacting social relations of care, responsibility and identity. The consumption of toys challenges the notion that cosmopditan moral viewpoints can simply be willed 
into existence. In the case of the Tho as and Friends recall, parents took up a moral response that few ethicists would call them on: a fundamental desire to protect their children from harm. We need to think more deeply about whether protection of harm is the only moral reaction a parent can or shouldhave to something like a toy recall. Exploring moral emotions requires us to see how emotion works to constitute people as legitimate and illegitimate objects of emotion. ${ }^{58}$

If a model of intensive parenting and the marking of childhood as sacred makes it difficult for parents to move from the personal to the collective, it seems fi ing to end with a question that theorists of consumption have posed many times: Is the model of citizen consumer a dangerous one? Th ories of consumption which recognise that children are not independent economicactors, and that speak to the complex emotional life worlds of childhood, will be better able to understand how morality can be built in the space of consumption. ${ }^{59}$ As Barnett et al. note, we need to speak of everyday consumption practices as 'ordinarily ethical, as practices through which we construct a life through negotiating practical choices about routine consumption. ${ }^{60}$ While it is clear that childhood consumption requires a uniquemodel of political consumerism, it also provides an important opportunity to explore a consumer identity where the identity being built, in this case the identity of parent, is already a volatile 'moral category'. The online responses to toy safety register a narrative of protection, but they also register deep anxieties amongst parents about being good parents. It would seem that consumption could easily be put in the service of global ethics if it involves consumers who are trying to be 'good parents'. Yet, as the analysis of toy consumption demonstrates, understanding the complexities of caring for those closest to us is critically important to the understanding of caring at a distance.

For scholars of global humanitarianism, we might refinethe concluding question further and askif a model of humanitarian as consumer is a dangerous one? Scholars of humanitarianism have long pointed out the important historical connections between the rise of global capitalism and global humanitarianism, paying particular attention to nineteenth-century anti-slavery movements as an emblematic example. ${ }^{61}$ Th s scholarshiphas not typically reduced the humanitarian to consumer as the critical question for global humanitarianism is not whether or not global connections exist, but rather how and when such connections mobilise social and political action. I conclude that the emotional landscape of consumption off rs the possibility of mobilising action when the sentiment itself can travel, and in this sense, we need to speak of 'aff ctive' models of connection. Media cultures may well provide connection between humanitarians and so-called victims, but as in the historical lessons of the past, connection alone is not enough. The case of children's toys demonstrates that in the face of apparent threat, we can seek to guard national and domestic borders, and deny such connection. Distant vulnerable children may trigger powerful rescue narratives, but close, apparently vulnerable children trigger equally powerful narratives of protection. Perhaps, then, the greatest danger to a 
global humanitarianism that seeks a more radicalvision of justice, is not the embracing of a consumer identity, but rather, a neoliberal discourse of parenting in which the spectre of risk only erves to incite the emotion offear.

\section{Notes}

1 Given the great variety of moral problems that face consumers, the term 'ethicalconsumption' is clearly a problematic catch-all term for this range of practices, and as T. Lewis and E. Potter note, the fi ld of ethical consumption mirrors this in its 'inchoate' drawing on political economy, sociology, philosophy and cultural studies. See 'Introducing EthicalConsumption', in T. Lewis and E. Potter (eds), Ethical Consumption: A Critical Introduction (Oxon and New York: Routledge, 2013), p. 5. Jo Littl $r$ also notes that a distinction between moralism and morality is important to the analysis of consumption. See Radical Consumption: Shopping for Change in Everyday Life (Maidenhead: McGraw-Hill, Open University Press, 2009), p. 14 In this chapter I will use the general terms 'political consumerism' and 'ethicalconsumption' with the recognition that this may simplify a complex philosophicalspace.

2 L. Nielson, 'Buycott or Boycott? Understanding Political Consumerism', Journal of Consumer Behaviour, 9 (2010), pp. 214-27. Certain practices, like boycotting, have become feminised in that they are more often performed by women. See D. Stolle and M. Micheletti, Political Consumerism: Global Responsibility in Action (New York: Cambridge University Press, 2013), p. 77. Some research has shown that fathers are more critical of 'hyper-materialism' than mothers. See F. Shirani, K. Henwood and C. Coltart, 'Meeting the Challenges of Intensive Parenting Culture: Gender, Risk Management, and the Moral Parent', Sociology, 46:1 (2012), pp. $25-40$.

3 Stolle and Micheletti, Political Consumerism, p. 39.

4 C. Barnett, P. Cloke, N. Clarke and A. Malpass, Globalizing Responsibility: The Political Rationalities of Ethical Consumption (Hoboken: Wiley-Blackwell, 2011), p 212.

5 Littl r, Radical Consumption, p. 77, emphasis in original.

6 P. Singer, 'Famine, Affl nce and Morality', Philosophy and Public Affairs, 1:3 (ppring 1972).

7 A. Smith, The Theory of Moral Sentiments (Indianapolis: Liberty Fund, 1984 [1759]).

8 S. Bookman, 'Feeling Cosmopolitan: Experiential Brands and Urban Cosmopolitan Sensibilities', in D. Spencer, K. Walby and A. Hunt (eds), Emotions Matter: A Relational Approach to Emotions (Toronto: University of Toronto Press, 2012), p. 250.

9 P. Gerbaudo, Tweets and the Streets: Social Media and Contemporary Activism (London: Pluto Press, 2012), p. 77.

10 Gerbaudo, Tweets and the Streets, p. 77.

11 Gerbaudo, Tweets and the Streets, p. 160.

12 See, for example, L. Suski, 'Children, Suff ring and the Humanitarian Appeal', in R. A. Wilson and R. D. Brown (eds), Humanitarianism and Suffering: The Mobilization of Empathy (New York: Cambridge University Press, 2009), pp. 202-22, and L. Suski, 'Humanitarianism as a Politics of Emotion', in D. Spencer, K. Walby and A. Hunt (eds), Emotions Matter: A Relational Approach to Emotions (Toronto: University of Toronto Press, 2012), pp. 124-36.

13 L. Hunt, Inventing Human Rights: A History (New York: W. W. Norton and Company, 2007), p. 26.

14 P. Ariès, Centuries of Childhood (Harmondsworth: Penguin Bodks, 1960).

15 G. Cross, 'Toys', in P. Fass (ed.), Encyclopedia of Children and Childhood: In History and Society, Vol. 3 (New York: Macmillan Reference, 2004), Web Version. 
16 B. Langer, 'Commodifi d Enchantment: Children and Consumer Capitalism', Thesis Eleven, 69 (2002), pp 67-81.

17 Some research suggests a less passive model of consumption under capitalism whereby children join some adults as 'creationist' consumers in that they are active in the production of what they consume. See Minna Ruckenstein's study of Habbo Hotel, an online gaming world for children and teenagers: 'Children in Creationist Capitalism', Information, Communication and Society, 14:7 (2011), pp 1060-76.

18 J. Schor, Born to Buy: The Commercialized Child and the New Consumer Culture (New York: Scribner, 2004).

19 Langer, 'Commodifi d Enchantment', p. 78.

20 Langer, 'Commodifi d Enchantment', p. 73. Of course, it must also be noted that many children around the world exist outsideof this model precisely because they do not figure at all in practices of consumption.

21 D. T. Cook, 'The Missing Child in Consumption Th ory', Journal of Consumer Culture, 8:2 (2008), p. 219.

22 P. Bourdieu, Distinction: A Social Critique of the Judgement of Taste, trans. Richard Nice (Cambridge, MA: Harvard University Press, 1984).

23 See for example Z. Bauman, Consuming Life (Cambridge: Polity Press, 2007).

24 Cook, 'The issing Child in Consumption Th ory', pp. 232,234.

25 Cook, 'The issing Child in Consumption Th ory', p. 235

26 T. Edwards, Contradictions of Consumption: Concepts, Practices and Politics in Consumer Society (Buckingham: Open University Press, 2000), p. 107.

27 Z. Bauman, Liquid Modernity (Cambridge: Polity Press, 2000); Bauman, Consuming Life.

28 For a review of these debates, see I. Frønes, The Autonomous Child: Theorising Socialization (New York: Springer, 2015).

29 D. Soron, 'Sustainability, Self-Identity, and the Sociology of Consumption', Sustainable Development, 18:3 (2010), p. 179.

30 Soron, Sustainability, Self-Identity, and the Sociology of Consumption', p. 180.

31 V. A. Zelizer, The Purchase of Intimacy (Princeton: Princeton University Press, 2005).

32 C. Faircloth, Militant Lactivism? Attachment Parenting and Intensive Motherhood in the UK and France (Oxford: Berghahn Bodks, 2013), p. 33.

33 F. Shirani, K. Henwood and C. Coltart, 'Meeting the Challenges of Intensive Parenting Culture: Gender, Risk Management, and the Moral Parent', Sociology, 46:1 (2012), pp. $25-40$.

34 Wall argues that the re-emergence of an interest in attachment parenting makes the intensification of parenting abundantly clear. Gone are the biological claims that came with the classic research of John Bowlby. Th se claims are replaced by an attachment that must be constantly built and monitored by the parent, again, largely mothers (Conference presentation, Annual Meetings of the Ganadian Sociological Association, Brock University, 2014).

35 G. Wall, 'Mothers' Experience with Intensive Parenting and Brain Development Discourse', Women's Studies International Forum, 33:3 (2010), pp. 253-63.

36 A. Romagnoli and G. Wall, "II know I'm a good mom”: Young, Low-Income Mothers' Experiences with Risk Perception, Intensive Parenting Ideology and Parenting Education Programmes', Health, Risk and Society, 14:3 (May 2012), pp. 273-89.

37 Romagnoli and Wall, “'I know I'm a good mom", p. 286.

38 See www.cpsc.gov. Accessed 14 july 2017.

39 H. Babuji, Not Just China: The Rise of the Recall in the Age of Global Business (New York: Palgrave Macmillan, 2011). 
40 Mel Y. Chen, Animacies: Biopolitics, Racial Mattering, and Queer Affect (Durham, NC and London: Duke University Press, 2012).

41 www.jumpingmonkeys.com/jumpingmonkeys/2007/06/thomas_train_re.html. Accessed 14 July 2017.

42 S. Garfin le, 'Choo on this', Washington Post (13 June 2007), http:// voices.washingtonpost. com/parenting/2007/06/not_the_trains.html. Accessed 14 july 2017.

43 Note that the recall was not mentioned in major news pieces about the Mattel purchase of the company. See for example B. Barnes, 'Tho as the TankEngine to Receive a MultimillionDollar Sheen', New York Times (30 December 2012), www.nytimes.com/2012/ 12/31/business/ media/ mattel-to-give-thomas-the-tank-engine-a-multimillion-dollar-sheen.html?_r=0. Accessed 14 july 2017.

44 Barnett et al., Globalizing Responsibility, p. 125.

45 See for example, Stolle and Micheletti, Political Consumerism.

46 Wall, 'Mothers' Experience with Intensive Parenting and Brain Development Discourse'.

47 Th re are, however, many examples from the world of contemporary childhood where affl nt children are engaged in activities that make connections with others around the world. For example, in Canada, the 'toonie, toonie' (the commonname for the two-dollar coin) birthday party has become popular where children bring two toonies for the birthday girl or boy. The birthday girl or bo keeps one bonie for thenselves, and domates another to charity.

48 Faircloth, Militant Lactivism?

49 A. Hochschild, The Managed Heart: The Commercialization of Human Feeling (Berkeley: University of California Press, 2014 [ 983]).

50 Chen, Animacies, p. 167.

51 Chen, Animacies, pp. 170, 171

52 Chen, Animacies, p. 188.

53 Refugee organisations in Canada reported a surge of interest in sponsorship after the publication of the photographs of Alan Kurdi (CBC, 2 September 2016, www.cbc.ca/news/ canada/ manitoba/ image-of-alan-kurdi-s-body-led-to-spike-in-sponsorship-of-syrian-refugeesgroup-says-1.3746552. Accessed 14July 2017). It was soon reported that Alan Kurdi's family was trying to get to Canada. Weeks later the new Liberal government announeed that they would support an incieased number of Syrian refugees to Canada.

54 Suski, 'Children, Suff ring and the Himanitarian Appeal'.

55 E. Langmuir, Imagining Childhood (New Haven: Yale University Press. 2006), p. 230.

56 Littl r, Radical Consumption, p. 86.

57 Littl r, Radical Consumption, p. 91

58 S. Ahmed, The Cultural Politics of Emotion (New York: Routledge, 2004).

59 Cook, 'The issing Child in Consumption Th ory', p. 233.

60 Barnett et al., Globalizing Responsibility, p. 28.

61 See R. A. Wilson and R. D. Brown (eds), Humanitarianism and Suffering: The Mobilization of Empathy (New York: Cambridge University Press, 2009).

\section{References}

Ahmed, S., The Cultural Politics of Emotion (New York: Routledge, 2004).

Ariès, P., Centuries of Childhood (Harmondsworth: Penguin Bodks, 1960).

Babuji, H., Not Just China: The Rise of the Recall in the Age of Global Business (New York: Palgrave Macmillan, 2011). 
Barnes, B., 'Tho as the TankEngine to Receive a Multimillion-Dollar Sheen', New York Times (30

December 2012), www.nytimes.com/2012/12/31/business/media/mattel-to-give-thomasthe-tank-engine-a-multimillion-dollar-sheen.html?_r=0. Accessed 14 jly 2017.

Barnett, C., P. Cloke, N. Clarke and A. Malpass, Globalizing Responsibility: The Political Rationalities of Ethical Consumption (Hoboken: Wiley-Blackwell, 2011).

Bauman, Z.,Liquid Modernity (Cambridge: Polity Press, 2000).

Bauman, Z., Consuming Life (Cambridge: Polity Press, 2007).

Bookman, S., 'Feeling Cosmopolitan: Experiential Brands and Urban Cosmopolitan Sensibilities', in D. Spencer, K. Walby and A. Hunt (eds), Emotions Matter: A Relational Approach to Emotions (Toronto: University of Toronto Press, 2012), pp. 240-59.

Bourdieu, P., Distinction: A Social Critique of the Judgement of Taste, trans. Richard Nice (Cambridge, MA: Harvard University Press, 1984).

Chen, Mel. Y., Animacies: Biopolitics, Racial Mattering, and Queer Affect (Durham, NC andLondon Duke University Press, 2012).

Cook, D. T., 'TheMissing Child in Consumption Th ory', Journal of Consumer Culture, 8:2 (2008), pp. $219-43$.

Cross, G., 'Toys', in P. Fass (ed.), Encyclopedia of Children and Childhood: In History and Society, Vol. 3 (New York: Macmillan Reference, 2004), Web Version.

Edwards, T., Contradictions of Consumption: Concepts, Practices and Politics in Consumer Society (Buckingham: Open University Press, 2000).

Faircloth, C., Militant Lactivism? Attachment Parenting and Intensive Motherhood in the UK and France (Oxford: Berghahn Bodks, 2013).

Frønes, I., The Autonomous Child: Theorising Socialization (New York: Springer, 2015).

Garfin le, S., 'Choo on this', Washington Post (13 June 2007), http:// voices.washingtonpost.com/ parenting/2007/06/not_the_trains.html. Accessed 14 july 2017.

Gerbaudo, P., Tweets and the Streets: Social Media and Contemporary Activism (London: Pluto Press, 2012).

Hochschild, A., The Managed Heart: The Commercialization of Human Feeling (Berkeley: University of California Press, 2014 [ 983$]$ ).

Hunt, L., Inventing Human Rights: A History (New York: W. W. Norton and Company, 2007).

Langer, B., 'Commodifi d Enchantment: Children and Consumer Capitalism', Thesis Eleven, 69 (2002), pp. 67-81.

Langmuir, E., Imagining Childhood (New Haven: Yale University Press, 2006).

Lewis, T. and E. Potter, 'Introducing EthicalConsumption', in T. Lewis and E. Potter (eds), Ethical Consumption: A Critical Introduction (Oxon and New York: Routledge, 2013), pp 3-24.

Littl r, J., Radical Consumption: Shopping for Change in Everyday Life (Maidenhead: McGraw-Hill, Open University Press, 2009).

Nielson, L., 'Buycott or Boycott? Understanding Political Consumerism', Journal of Consumer Behaviour, 9 (2010), pp. 214-27.

Romagnoli, A. and G. Wall, “'Iknow I’m a good mom”: Young, Low-IncomeMothers' Experiences with Risk Perception, Intensive Parenting Ideology and Parenting Education Programmes', Health, Risk and Society, 14:3 (May 2012), pp. 273-89.

Ruckenstein, M., 'Children in Creationist Capitalism', Information, Communication and Society, 14:7 (2011), pp 1060-76.

Schor, J., Born to Buy: The Commercialized Child and the New Consumer Culture (New York: Scribner, 2004).

Shirani, F., K. Henwood and C. Coltart, 'Meeting the Challenges of Intensive Parenting Culture: Gender, Risk Management, and the Moral Parent', Sociology, 46:1(2012), pp. 25-40. 
Singer, P., 'Famine, Affl nce and Morality', Philosophy and Public Affairs, 1:3(Spring 1972), pp. $229-43$.

Smith, A, The Theory of Moral Sentiments (Indianapolis: Liberty Fund, 1984 [1759]).

Soron, D., 'Sustainability, Self-Identity, and the Sociology of Consumption', Sustainable Development, 18:3 (2010), pp. $72-81$

Stolle, D. and M. Micheletti, Political Consumerism: Global Responsibility in Action (New York: Cambridge University Press, 2013).

Suski, L., 'Children, Suff ring and the Humanitarian Appeal', in R. A. Wilson and R. D. Brown (eds), Humanitarianism and Suffering: The Mobilization of Empathy (New York: Cambridge University Press, 2009), pp. 202-22.

Suski, L., 'Humanitarianism as a Politics of Emotion', in D. Spencer, K. Walby and A. Hunt (eds), Emotions Matter: A Relational Approach to Emotions (Toronto: University of Toronto Press, 2012), pp. 24-36.

Wall, G., 'Mothers' Experience with Intensive Parenting and Brain Development Discourse', Women's Studies International Forum, 33:3 (2010), pp. 253-63.

Wilson, R. A. and R. D. Brown (eds), Humanitarianism and Suffering: The Mobilization of Empathy (New York: Cambridge University Press, 2009).

Zelizer, V. A., The Purchase of Intimacy (Princeton: Princeton University Press, 2005). 


\title{
11
}

\section{Liking visuals and visually liking on Facebook: From starving children to satirical saviours}

\author{
Rachel Tavernor
}

Thedevelopment of social media sites, suchas Facebook (founded 2004) and Twitter (founded 2006), has changed humanitarian non-governmental organisations' (NGOs) media practices and subsequently altered the ways that supporters and publics are engaged. ${ }^{1}$ Th s chapter focuses on a recent movement for NGOs to humourhumanitarianism to achieve visibility on social networks, like Facebook. In particular, examining how visuals of humanitarianism have moved away from depicting starving children awaiting assistance towards satirical representations of 'saving' those in need. Th s chapter also contributes an understanding of how people participate in these diff ring narratives on Facebook with an analysis of interviews with young people (aged 18-35) in theUK.

\section{Starving children}

Since the 1970s, the images of extreme hunger communicated by NGOs have been widely criticised as overtly negative and representatively inaccurate, depicting starving children through a colonialgaze. ${ }^{2}$ In 1989, the General Assembly of European NGOs adopted a new Code of Conducton the 'Images and Messages relating to the Thi d World (1989). The document called for NGOs to avoid using apocalyptic or pathetic images that fuel prejudices and promote a sense of Northern superiority (1989: 2). Despite the adoption of new codes, decades later, the representations of humanitarianism in NGO adverts still includeisolated suff ring children in need of a 'saviour'. Most notably, these representations are mobilised in daytime television adverts; using close up shots of skeletal bodies, habitually children, surrounded by flies. ${ }^{3}$ However, on Facebook, dominant images of starving children are now filtered by a structure that privileges content that users can 'like,' 'comment' or 'share'. Facebook algorithms, along with the architects of Facebook, have now become the new 'gatekeepers' of humanitarian communication and NGOs have started to adapt their representations of humanitarianism. In particular, I propose that the Facebook 'like', and users' interaction online, changes the visual communication used by 
contributing to the governance of visibility. I will explore these themes by using the UK Enough Food IF (2013) anti-poverty campaign as my site of investigation.

On the 23 January 2013, the Enough Food IF campaign was launched by a coalition of the largest leading humanitarian NGOs in the UK, including Save the Children, Oxfam and Christian Aid. ${ }^{4}$ Thecampaign broadly aimed to tackle extremeinternationalhunger by rallying the British public to use their national citizenship to pressure their MPs, primeminister and chancellor to take politicalactionon aid, taxavoidance, biofuels and government transparency. Due to a limited fi ancial budget, the Enough Food IF campaign organisers predomimantly communicated theirmessages across digital platforms, such as Facebook, Twitter and YouTube (Enough Food IF Interview 2013).

TheEnough Food IF campaign's Facebook page was launched the same day as the campaign. In the fi st twelve months, content published by the campaign received an average of 125likes per post, totalling 52,217 and 77 shares per post, totalling 31,953. TheEnough Food IF campaign's internal Digital Insights reported, 'Social media was the hero in this campaign. With strong engagement rates on content, social media was also the largest referrer [to the campaign website]. ${ }^{5}$ As a coalition, the Enough Food IF campaign organisers agreed to have a tight-loose control of their social networks. For the key moments, thelaunchin January, the UKbudget stunt in March and for their rallies at the G8 Summit in June 2013, the steering group took tight control of their messaging, branding and media image. During these 'moments', the visual communication, which included videos, images and info-graphics, achieved the most interaction on Facebook. However, in the time between these 'moments', there was a loose arrangement of various NGOs (varying in size) authoring communication for the Facebook page each week, during these times the frequency of posts increased, however the circulation of the material reduced. Th s indicates that the coalition, who were advised by social media consultants, were better equipped at producing communications that fi ed the architecture of Facebook.

Nick Couldry proposes that media research is often constrained by a focus on texts or audiences instead of the 'open set of practices relating to, or oriented around, media. ${ }^{6}$ While this chapter focuses on the practices that occur online, it is important to note that they are intertwined with wider open sets of actions. Couldry argues that practice theory can contribute to translating the hype of a 'digital revolution' by asking: 'What types of things do people do in relation to media? And what types of things do people say (think, believe) in relation to media??' Th s chapter explores the acts of 'liking visuals' and 'visually liking' on Facebook, to examine how Facebook structures both discourses and practices in humanitarian NGO campaigns. First, I analyse the act of 'liking' visuals on Facebook by examining the architecture of the social networking site, to understand how visibility of communications is governed and what actions are permitted. Here, visibility is explored using the work of Taina Bucher as a 'highly contested game of power in which the media play a crucial role.. Second, I address the act of visually 'liking' content on Facebook with reference to eight interviews with young British adults (aged 18-35) to investigate their actions 
taken online and how campaign acts contribute to 'presencing' politicalengagement. I conclude with a discussion on how humouning hunger, to fit the architecture of Facebook, potentially pacifi s the pditics of poverty and humanitarian intervention.

\section{'Liking' visuals}

\section{Architectures of action}

Theact of clicking a button to support a campaign or cause has been criticised widely, both within NGOs and externally, that 'clicktivism' is a downgrade of activism proper. ' The focus on the 'click' is an oversimplific tion of the many practices that take place in digital environments. Discussing the architecture of online spaces is not a new perspective. ${ }^{10}$ However, workon the architecture of social networking sites that address humanitarian campaigns has previously neglected to address who the architects are and the implicit ideology of their design ${ }^{11}$ I apply these fundamental questions to the social networking site Facebook as the starting point of this chapter.

Facebook was founded in the United States in 2004 as a network for Harvard University students to share 'social' information. In 2005, the network was open to other US educational institutions, corporate professionals and in the following year was made public. ${ }^{12}$ Checking social networking sites has now become part of daily life; within the UK, twenty-fourmillion people log on to Facebook every day. ${ }^{13}$ With the penetration of social networks into everyday life, NGOs now use online platforms as a tool to connect and communicate to 'networked publics. ${ }^{14}$ In 2009, the introduction of Facebook 'pages' facilitated a space for organisations, including NGOs, to create public profiles. Facebook 'pages' mirror individual profiles, with the ability to publish content to a 'timeline' and interact as a 'friend' in a user's 'News Feed' (introduced in 2009).

Mark Zuckerberg, most visible architect of Facebook and CEO, states that 'the goal of the company is to help people to share more in order to make the world more open and to help promote understanding between people.. ${ }^{15}$ Zuckerberg articulates a philosophy that resonates with humanitarian values of helping others to create a better world with the promise to 'build richer relationships with the people we love and care about. ${ }^{16}$ However, as will be explored in this chapter, the mechanics of Facebook diff rs from the ethos that Zuckerberg attemptsto promote. I will examine three ways that the 'social' is constructed by the architecture of Facebook: 'liking', 'sharing' and having Facebook 'friends'. For each, I explore how their implicit ideology shapes participation in himanitarian campaigns.

\section{Liking}

Facebook aims to be a positive network, where 'users are constantly prompted to like, enjoy, recommend and buy as opposed to discuss or critique. ${ }^{17}$ In 2009, the 'like' button was introduced as a way for users to acknowledge content and contribute to 
the positivity of the network. To 'like' content and 'pages' is now the most popular action taken on Facebook; every day the 'like' button is hit 3.2 billion times across the world contributing to what some have termed a 'like economy'. ${ }^{18}$ Facebook's architecture scripts actions that conform to an 'affirmative atmosphere, in which people only agree and do not disagree or express discontent and disagreement. ${ }^{19}$ Consequently, paradoxical relationships are produced when NGO campaigns, which protest against hunger, poverty and ultimately the status quo, communicate through Facebook. In the case of the Enough Food IF campaign, Facebook users were nolonger confronted by images of a suff ring child, whichaudiences may wish to 'dislike' but were invited to engage with poverty through visuals of satiricalvideos, smiling children and even cats engaging with the campaign. ${ }^{20}$

While users have petitioned Facebook for a 'dislike' button, Zuckerberg has continually argued that to say something 'isn't good ... [is] not something that we think is good for the world. So we're not going to build that.'. ${ }^{21}$ Zuckerberg attempts to silence the corporate agenda of Facebook and instead vocalises that its decisions are based on producing a network that is good for the world. To ensure the positivity of the network, Facebook's architecture limits the interactivity of users. While Facebook users have the opportunity to choose the activities that they wish to participate in, they are confin $d$ by the architecture of Facebook to predefin $d$ actions. Users are directed to engage with communications by liking, commenting or sharing. In September 2015, while I was conducting research for this chapter, Zuckerberg announced that Facebook was working on a button for users to 'express empathy' because for some posts, users 'may notfeel comfortable to "like" that post, but your friends and people want to be able to express that they understand.22 Yet, as will be explored in this chapter, the architecture of Facebook is shaped by corporate actors who definethe need for the social to be positive. On social networks, corporations aim to build 'positive' relationships with consumers, who will endorse rather than reject their brands. While news articles reported that Facebook was creating a dislike option, the button did not take the form of a 'dislike' button. ${ }^{23}$ In 2016, Facebook launched a range of seven emoticons: 'Like', 'Love', 'Haha, 'Yay', 'Wow', 'Sad' and 'Angry'. The emoticons still privilege the 'like' button, which remains the primary button that users have to click to access diff rent responses.

\section{Sharing}

Zuckerberg's public statements about Facebook emphasise the ability to 'share' content. ${ }^{24}$ Similar to the act of 'liking' the ability to 'share' is framed as a positive act, whereby 'sharing is an expression of your caring. ${ }^{25}$ The ability to 'share' encourages users to contribute to a circulation of content which is monitored by Facebook. Christian Fuchs argues that Facebook's tracking of users' actions is a strategy that 'violates their [users'] privacy for economicends.'. In the case of campaigning, the act of sharing campaign infomation is not new. For centuries, social movements 
have distributed leafl ts to strangers, neighbous and friends asking fortheirsupport. Sharing also goes beyond sharing communications. Activism is a shared activity, which involves a shared identity and common understanding of how to make or change the future. Yet, when the act of sharing is conducted through Facebook it diff rs. Theact to 'share' content on Facebook contributes to data fl ws and, similar to the 'like' button, is 'instantly tumed into valuable consumer data. ${ }^{27}$ While the act of sharing may echo traditional activist actions by contributing to a circulation of campaign material, the action also contributes to Facebook's implicit corporate agenda. Th refore, in the case of the Enough Food IF campaign, the NGOs requesting supporters to 'share' their content, is also a request for them to 'share' their personal data for 'corporate social media monitoring', although NGOs do not fi ancially benefit rom this transaction. ${ }^{28}$

\section{Facebook 'friends'}

Facebook promotes all relationships between users as 'friendships', in contrast to other social networking sites, such as Twitter and Instagram, which use the term 'follower. Corporate and charitable organisations producing 'pages' also occupy the position in users' 'newsfeeds', similar to a 'friend.' The architecture of Facebook promotes social exchanges between users, as well as 'pages', as socially valuable. Defini $g$ the connection as a 'friendship' implies that it is a reciprocal relationship that both find utually benefi ial.

By defini g social connections as a 'friendship', both positivity and intimacy are implied. The positive connotations of 'friendships' are integral to the way Facebook's architecture structures positive sentiments. Friendshipalso implies a degree of intimacy whereby users wish to 'share' the personal in semi-public spaces. A user sharing the 'personal' again benefits the corporate agenda of Facebook, which is then able to capture intimate information that can be instantly sold to advertisers. Popular social networking sites that preceded Facebook, like MySpace (founded 2003), produced less intimate spaces, with users adopting pseudonyms and only sharing one or two images, whereas Facebook encourages users to 'log on and carry out theirdigital lives with their offlineidentities', proposing that 'the use of authentic identity helpspeople get the most value out of the site..$^{29}$ Facebook promotes that the authenticity in self-presentation helps people to connect and contribute to friendships both on ad offline.

In the case of the Enough Food IF (2013) campaign, supporters were encouraged to 'like' Facebook content and 'share' YouTube videos with their Facebook 'friends'. Th se ideologically driven actions were determined not by the NGOs themselves but by the architecture of Facebook. The adoption of commercial strategies in humanitarian communication has a long history. Visual communication used by NGO campaigns is often developed by external corporate branding organisations. While this signals a change in the communications produced, the NGO maintains control of the messaging of these materials. However, in the case of Facebook, 
the architecture is imposed not by the NGO but by the social networking platform, which dictates both the type of communication produced and how users can respond $\mathrm{t}$ issues, such as encouraging people to 'like' global poverty.

\section{Governing visibility}

In the twentieth century the communication of humanitarianism was governed by traditional media powers, including mainstream newspaper and TV news editors. The power to govern visibility of contemporary humanitarianism in social networking environments shifts from traditional media editors towards 'technological mechanisms and algorithmic selections operated by large social media corporations. ${ }^{30}$ I propose that these algorithms and their producers, which dictate a set of rules, are the new 'gatekeepers' that NGOs have to negotiate to achieve visibility. While Facebook 'pages' facilitate a space for organisations to have editorial control and to directly publish their own communications, research conducted in North America shows that only 6 per cent of users return to a page once liking it. ${ }^{31}$ For communication to achieve visibility on Facebook, NGOs need to penetrate the News Feeds of Facebook users, where people spend the majority of their time online. ${ }^{32}$

The Facebook News Feed was created in 2006 and is controlled by algorithms to contribute to the personalisation of users' experiences..$^{33}$ At the time of the Enough Food IF campaign, the News Feed was governed by the Edge Rankalgorithm, which determined what was displayed in a uer's News Feed by calaulating:

1. The Facebook relationship between the NGO and the Facebook user. For example, how often the user interacts with the NGO, defin $\mathrm{d}$ in the algorithmas the Affinity.

2. The type of content and how people have engaged with the content, classifi $\mathrm{d}$ as theEngagement.

3. And fi ally the Time Decay of the post: Facebook wants the News Feed to contain recent posts. $^{34}$

On 6 August 2013, Facebook announced that the Edge Rank algorithm had been updated to include more factors. However, users' interaction with the content is still valued in selecting material for the News Feed. In particular, older content can return to users' News Feeds if it is 'still getting lots of likes and comments. ${ }^{35}$ Thevisibility of content is dependent on these numerical interactions.

Michel Foucault, with reference to Jeremy Bentham's design for the panopticon penitentiary, stated that 'the diagram of a mechanism of power reduced to its ideal form, identifi s the power relationships that are rooted in visibility and surveillance. ${ }^{36}$ For Foucault, visibility is an apparatus of control that governs human behaviour. In the case of social networking environments, visibility is not a punishment 
but 'functions as a reward. ${ }^{37}$ For any interaction to take place, users and organisations need to be visible. Facebook dictates that onlyspecific communications, whichfulfil the algorithmicselection, will penetrate users' News Feed and be granted a degree of visibility. Achieving visibility on social networking platforms is also a temporary status. Unlike the circular panopticon, where the threat of visibility is continuous, the Facebook News Feed is a linear space that is continually updated by the algorithm, with posts at the top being most prominent.

\section{Transience of visibility}

The Facebook algorithm calaulates the 'time decay' of communication, privileging recent posts by granting them visibility as well as pushing them towards the top of the News Feed. Although the algorithm dictates what communication temporarily penetrates the News Feed, the user's command of the space brings a further degree of transience to the visibility. Michel de Certeau, in The Practice of Everyday Life, discusses the practice of walking in the city, 'the networks of these moving, intersecting writings compose a manifold story that has neither author nor spectator, shaped out of fragments of trajectories and alterations of spaces. ${ }^{38}$ Similarly, Facebook users scrolling through their News Feed can be perceived as 'walkers' temporarily experiencing spaces in $\mathrm{fl} \mathrm{x}$, following fragments of stories encountered on their visual joumeys. While photos, status updates and shared links may be visible to the user 'walking' their individual News Feed, the whole is not encountered and neither is the collective.

De Certeau positions the 'walker' who is 'below the thresholds at which visibility begins' in contrast to the 'voyeur' who has an elevated experience of the city, who sees the city as a whole and 'allows one to read it, to be a solar Eye, looking down like a god. ${ }^{39}$ The architectures of social networks, as discussed above, are not designed for the complexities of humanitarian politics but for consumerism. ${ }^{40}$ Facebook users are prevented from the elevated view of the 'voyeur' who might read humanitarian communication as a complex process that maps across diff rent inequalities (economic,social, gender, racial). Users encounter only fragments of humanitarian stories, which fit the commercial design of the platform. Theprocess that commodfi s the lives of people living in poverty, and the contextual politics, are excluded. However, as 'walkers' users are positioned as practitioners, who have the ability to participate in their Nws Feed as a sie of practice.

The way in which technologies change the request for publics to act, but also the act itself, is critiqued in the work of Jodi Dean, Lilie Chouliaraki, Mirca Madianou and others. ${ }^{41}$ Although Chouliaraki does not focus on social networking platforms her analysis of post-humanitarian communication is relevant to the social media used within the Enough Food IF campaign. Chouliaraki discusses how the 'technologisation of action' has resulted in acts being simplifi $\mathrm{d} .{ }^{42}$ She argues that online activism now promotes 'effo tless' action, without the need for a sustained commitment to the cause. Theactions promoted in the architecture of Facebook are 
easy; 'sharing' a video or 'liking' a post is not a time-consuming or skilled activity. Chouliaraki further juxtaposes the ease of expressing 'solidarity' from the 'comfort of her living room' with the suff ring of the distant other. ${ }^{43}$

Humanitarian NGOs promote these time efficient practices. In the Enough Food IF campaign, the time that actions would take featured prominently in the communications used. On the Save the Children website, for example, supporters were directed to follow the campaign on social media in 'two minutes' or take part in producing a YouTube video in 'fi e minutes'. Robert Hassan, in his workon network time, discusses the role of the clock in the development of what Nigel Th ift calls 'capitalist time consciousness', which shapes an instrumental view that 'takes the world largely as given and attempts to find means of living ever more productively and efficiently in it. ${ }^{44}$ Keith Tester proposes that audiences of mediated suff ring rely on 'commonsense humanitarianism'; this uncritical understanding of humanitarianism is needed to promote 'time efficient practices. ${ }^{45}$ Antonio Gramsci defin $\mathrm{d}$ common sense as 'the conception of the world which is uncritically absorbed by the various social and cultural environments in which the moral individuality of the average man is developed. ${ }^{46}$

Instrumentalism can be identifi $\mathrm{d}$ in contemporary humanitarian communication that directs supporters towards 'time efficient' actions online that promotes, perhaps due to time, a decontextualised problem of poverty and a solution (taking action with NGOs) as a given. Th se time-bound practices produce a transactional mode of engagement that does not require a sustained commitment to a cause. The success of the Enough Food IF campaign on social networks was not measured by the quality of the supporters' engagement with the issues (by analysing their YouTube Videos, Facebook updates or Tweets); instead the success was measured by the number of actions taken as an indication of public engagement. Jodi Dean defin s a post-political formation of 'communicative capitalism' where the 'only thing that is relevant is circulation. ${ }^{47}$ The request by the Enough Food IF campaign for supporters to produce and circulate communications contributes to a 'massive stream of content, losing theirspecifi ity and merging with and into the data fl $\mathrm{w}^{\text {' }}{ }^{48}$ While producing a ' $\mathrm{fl}$ w' of communication acts as a catalyst forfurther 'likes', 'shares' and 're-tweets', the 'fl w' has a pace, dictated by algorithms, that produces fl eting weak communicative affin ies between supporters and/or NGOs, not shared political actions. ${ }^{49}$ Facebook users individually interact with the NGO communication visible in their News Feed - the practice of 'following', 'liking' or 'sharing' are individualendorsements. Endorsements diff $\mathrm{r}$ from exchanges, as the ' $\mathrm{fl}$ w' of communication is linear, with the 'endorser' absorbing the politics of another, not exclanging their own understanding.

\section{Visually 'liking'}

Nick Couldry, in his theorising of media as practice, uses the work of Ann Swidler (2001) to develop the notion of 'culture' in terms of 'two types of publiclyobservable 
processes ... fi st, practices themselves ... and, second, the discourse' which, as Swidler argues, is not what anyone says, but the system of meanings that allows them to say anything at all. ${ }^{50}$ Consequently, Swidler, as well as Couldry, propose a new understanding of 'culture' away from internal 'ideas' or 'meanings' towards open practices 'notable for theirunconscious, automatic, un thought character. ${ }^{51} \mathrm{By}$ analysing eight interviews with young people (aged 18-35),I investigate practices of participating in NGO campaigns through Facebook.

An interviewee commented that 'because its [visual communication] on Facebook, we're directed to "Like" poverty, which seems natural at the time' (Interview A). Theact of 'liking' poverty, presented as 'natural at the time', illustrates that actions within the architecture of Facebook can be experienced as instinctive. Yet, the interviewee, refl cting on her actions, perceived that a paradox occurs when asked to 'like' poverty. Th se tensions are explored by discussing ways that visually 'liking' can be understood as a fom of presencing' humanitarian action.

\section{Participation as 'presencing'}

People rarely self-identify as performers in everyday acts of self-presentation even though they frequently adjust or adapt behaviours to diff rent social settings, situations and audiences. ${ }^{52}$

Zizi Papacharissi, drawing on Erving Goffman, has argued that digital environments are condudive to online users participating in a performance of self-presentation. ${ }^{53}$ By adjusting and adapting theirbehaviour, people present diff rent 'faces' understood by Papacharissi as 'an information game' where information is concealed, discovered and revealed. ${ }^{54}$ Building on Papacharissi's workon self-presentation, I wish to deploy Couldry's theory of 'presencing' to understand individuals' practices of participation in NCO campaigns and communication. Couldry defin s 'presencing' as:

acts of managing through media a continuous presence-to-others across space ... oriented to a permanent site in public space that is distinctively marked by the producer for displaying that producer's self ... It responds to an emerging requirement in everyday life to have a public presence beyond one's bodily presence, to construct an objectific tion of onself. ${ }^{55}$

Similar to NGOs authoring communication that contributes to producing themselves as authentic and legitimate actors, individuals are 'presencing' themselves as campaigners of certain causes. Intertwined with individuals 'presencing' participation is the personalisation of politics and communications. Bennett and Segerberg define 'personalised' communication, for organisations or coalitions, which 'broker' action as involving 'opportunities for customisation of engagement with issues and actions. ${ }^{56}$ Thecustomisation of engagement and 'presencing' of individuals as 'supporters' contributes to a practice of self-expression. By 
organisations brokering action across social networks, which are increasingly refl ctors of individual self-expression, the customisation of action has focused on visually 'presencing' the self. ${ }^{57}$

TheEnough Food IF campaign included several opportunities for supporters to visually presence theirinvolvement in the campaign with Twibbons, visual petitions and YouTube videos, all of which, I propose, contribute to customising engagement that looks predominantly towards the 'self', rather than people living in poverty. The Twibbon was developed in 2009 by Storm Ideas, as a tool for users to customise their profile picture on Facebook and Twitter by adding a brand or charity's logo to show their public support for a 'cause. ${ }^{58}$ The Twibbon, now part of the architecture of Facebook, is a contemporary version of the traditional supporter ribbon, badge or car sticker. ${ }^{59}$

In the case of the Enough Food IF campaign, supporters were invited to add an IF logo to theirprofile image. Changing a Facebook profile image, the most visible part of the profile (due to the enforced public setting), is a practice of self-expression, which is typically temporary but contributes to a public archive of profile images, unless actively deleted. The visibility of the profile picture, along with the act of changing the image, which is publicised in 'friends' News Feeds, has the potential to raise awareness by reaching 'networked publics'. ${ }^{60}$ In the interviews, Facebook was discussed as a way that supporters became aware of campaigns. One interviewee acknowledged that their awareness of the Enough Food IF campaign was 'through a friend's Facebook' (Interview A) and another was made aware of new campaigns 'on Facebook mainly I'm not really signed up to any charity email lists' (Interview B). While raising awareness, the practice of adding Twibbons to profile pages also contributes to users identifying themselves as part of a movement. The practice of 'presencing' is a continuous 'project of the self' that requires users to take action to remain socially visible. ${ }^{61}$ However, users can only practice participation via a Twibbon for one cause at any one time. Traditionally, being part of a 'movement' is perceived as a sustained commitment until the goals of the campaign are met. However, the act of adding a single Twibbon for a given period contributes to conveying action that is a singular and temporary commitment.

\section{Self-expression and mobilising 'friends'}

The act of 'liking' content on Facebook is recognised by interview participants as a visible act that has the potential to address a public by penetrating the News Feeds of their 'friends'. Similar to Michael Warner's understanding of publics existing by participating in reading, writing and watching 'the discourse[s] that addresses them', the act of 'liking' was perceived as a semi-public act that calls a public into existence, whereby strangers meet by being addressed by a mutualfriend's action. ${ }^{62}$ Interviewees understanding the potential for their actions to be visible discussed that the ability to engage with NGO communication online was normatively 
positive. The interviews conducted indicated that young people perceive social networks as spaces to mobilise friends. One interviewee rationalised her action of 'liking' having the potential to make 'other people see it' and persuade Facebook 'friends' to also act:

I thinkbecause I know if you 'like' it or 'share' it - I thinkmaybe even if you just 'like' it - it comes up on yourfeed that you like something and then it will come up on my friend's News Feeds - so hopefully other people will see it and be persuaded to take action. (Interview C)

Refl cting on her relationship with NGO communication on Facebook, one interviewee commented that although she would 'like' many posts by NGOs, she discussed being more selective with the NGO material that she shared. She wanted to onlyshare content that would achieve interaction with her friends ('likes', 'shares' and 'comments') and that when communication achieved a lot of interaction, she felt that she was part of something bigger. However, typically the NGO communications that she has shared 'haven't got a massive amount of likes and comments and I think the problem is that only certain people will look at it - you know some of your friends on Facebook will look at it and others won't' (Interview C). Theinterviewee's refl ction on her use of Facebook and her 'friends' reception of NGO communica tion illustrates how campaigns are only visible for 'friends' that are actively willing to 'look'. Returning to my earlier argument that users 'walk' their News Feed, the interviewee's refl ctionillustrates that another degree of visibility/invisibility occurs once the communication penetrates the News Feed.

Several of the interviewees had volunteered overseas as part of the governmentfunded Platform 2 programme and discussed that by sharing their own stories and images of 'humanitarian' action, more of theirfriends had engaged with theirpersonal encounters of poverty (Interviews C, D, E). Thepersonalisation of poverty in this way echoes the mediation of celebrities' trips overseas, including a similar sentimental discourse, 'going to Kenya and seeing Kibera the large slum was heart-breaking' (Interview C). Thesharing of volunteer experiences on Facebook is botha communica tive act that raises awareness of the poverty that exists as well as an act of self-expression that contributes to identifying themselves as actors withina cause. Chouliaraki identifi s a recent humanitarian turn to self-expression, as a key feature of new media, which is a 'practical response to compassion fatigue, the public's apathy towards traditional iconographies of suff ring. ${ }^{63}$ However, self-expression and humanitarianism has a deeper heritage that dates back to the publication of early missionary work overseas that situate missionaries as benevolent actors. What has changed in recent decades is the tone of the communication that shapes self-expression. Previously self-expression in relation to humanitarianism was presented as a sacrifi e to the cause, with sober imagery of missionaries feeding people living in poverty. In contrast, missionary work and overseas volunteering is now promoted with imagery of smiling young people 
conducting overseas 'development' that contributes to the personal growth and fulfilment of the volunteer, while also 'saving' those in need.

Although interviewees all agreed that sharing NGO communication on Facebook is normatively positive, each participant discussed being selective about what they chose to share. The self-imposed criteria were either feeling 'really strongly about something and I feel that I want to encourage other people to do it' (Interview B) or because they believe that their friends will interact with it (Interview D). However, one interviewee was conscious that 'I don't want to put it [global poverty] in other people's faces' (Interview B), implying that the act of sharing communication could invade friends' personal spaces.

Each of the interview participants were asked to watch humanitarian NGO video clips and images during the interview and comment whether they would interact with the communication if they had encountered the imagery on Facebook. All participants rejected the imagery of a starving child, interpreting the image as 'negative' and 'repetitive'. Visuals of children smiling were generally perceived as 'positive' imagery and were a result of people already receiving international aid. Several interviewees commented that they would share the 'What has aid ever done for anyone?' and believed humour works':

I thinkhumouris a good way to engage people, it wasn't used in a way to make it seem lighthearted - so I thinkit draws you in more - obviously everyone likes to laugh and I thinkpositive images are always going to work much better than negative images because people see it as something diff rent. I thinkit defini ely works. (Interview C)

Interviewees understood humourand 'positive' imagery as 'working' due to it being 'something diff rent'. The att action to 'new' communication as a result of it being 'diff rent' indicates that there is a perceived need, by audiences, for humanitarian communication to be continually changing if it is to 'work'

\section{Satirical saviours}

Since 1985, ComicRelief has been producing telethons that includea juxtaposition of comedy performances alongside emotive pleas to help people living in poverty. Yet, the use of humourin the narratives of global poverty produced by NGOs has a much shorter history. Since 2005, in the era that Chouliaraki defin s as 'posthumanitarian', the humouning of poverty has been used intermittently in protest campaigns (Make Poverty History), fundraising appeals (ComicRelief) and in educational campaigns critiquing NGO representations (Radi-Aid). ${ }^{64}$ The humorous narratives have included self-refle ive critiques of the NGOs' own fundraising practices, subverting the traditional emotive plea, dramatic music and starving child. According to Cameron, using humourin public engagement, in particular for 
protest and education, has the potential 'to work as a hook to att act initial public interest in seriousissues ... [and] promote a sense of hope that change is possible.65 Thehumouring of hunger, which parodies the traditional narratives of poverty and humanitarian action, has gained large onlineaudiences. 'Africans for Norway', a spoof charity single that asks Africans to send radiators to Norway because 'Frostbite kills too', has been watched by nearly three million YouTube viewers (published online 6 November 2012). ${ }^{66}$ As a result of NGOs' desire to produce communications that circulate across social networks, the visuals used by campaigns have radically changed. The adoption of digital environments with implicit rules has challenged NGOs to produce satirical narratives of global poverty. The iconography of a starving child, who still remains a domimnt focus in televised NGO adverts, is replaced on social networks by 'likeable' content.

The Enough Food IF campaign's Facebook communication that achieved the most 'likes', 'shares' and 'comments' is a satirical video that asks 'What has aid ever done for anyone??. ${ }^{67}$ Save the Children UK produced the video, whichis directed by Paul Weiland (Blackadder and Mr Bean) and includes the actors Peter Serafin wicz, Joanna Scanlan and Matt Berry. The video was introduced by the organisation in a colloquial and friendly tone:

Hope you all had a great and eventful weekend! We certainlydid - withoutgiving too much away, it involved going undercover at an anti-aid rally and documenting what really goes on behind the senes ...

The short video, less than three minutes long, was published on 18 March 2013, two days prior to a UKbudget announement, a key 'moment' in the campaign that asked for the UK government to spend 0.7 per cent of Gross National Income (GNI) on international aid. Thequestion posed in the video resonates with the public scepticism on the value of aid. Henson et al. conducted an analysis of Mass Observation diaries on the topic of aid in 2008, which showed that people in the UK 'tend to be much better at picturing aid "failure" than aid "success"' 68 The video mimics a popular skit from Monty Python's Life of Brian (1979), that ironically asks, 'What have the Romans ever donefor us?' with the conclusionbeing that they signific ntly developed society. Similarly, in the Enough Food IF video, British characters are on their way to an anti-aid rally, determined to campaign against aid even after their discussion on the bus about the many 'successes' of international aid. The video satirises traditional NGO protest action, with the characters participating in a demonstration, singing their protest song and holding placards displaying their anti-aid messages, including 'Make Aid History' in the same font as the 2005 Make Poverty History logo.

The larger audiences that humorous narratives of global poverty have achieved online illustrate that laughter can be a successful 'hook' for audiences to click and watch. However, the way in whichsocial suff ring is represented determines the type 
of engagement provoked and contributes to the social relations formed between the North and the South. ${ }^{69}$ Tho as Hobbes, writing in England in the mid-seventeenth century, developed a theory that humourwas based on superiority over 'the defects of others' and that laughter was thus the 'roar of the victor. ${ }^{70}$ The premise for the 'What has aid ever done for anyone?' video is that the characters on the bus are both dim-witted and ignorant about the value of international aid. The humouris revealed in the incongruity of their determination to campaign an anti-aid message even after their dscussion about how aid is:

Providing 2 million people with clean water and sanitation, enabling 5 million children to go to school, vaccinating over 80 million children against killer diseases, helping people dying from preventable illnesses, nearly eradicating polio, and responding to 32 matural disasters across the glde in the hst year.

Applying Hobbes's theory, the laughter in the clip is provoked by the 'superior' audience witnessing the 'defective' view of the anti-aid campaigners. Thehumourof the video is contingent on the audience already supporting, or adopting during the clip, the pro-aid positon of the Fnough Food IF campaign.

Hobbes's theory of humouras depending on superiority is challenged in the work of Robert C. Solomon, who proposes 'laughter as the great leveller, beyond contemptor indignation, antithetical to pretention and pomp... to avoid the supposed bad taste of enjoying the Thee Stooges [a 1920's American comedy group] we encounter the much greater danger of taking ourselves too seriously. ${ }^{71}$ Hobbes and Solomonare absolute in theirdivergent theories about the uses of laughter, yet both approaches can be identifi $d$ in NGO communication. Solomon's claim that the authors of the comedy in truth laugh at themselves can be identifi $d$ in many of the NGOs' self-refle ive narratives of the work that they conduct. Yet, NGOs are specificaly only self-refle ive on their public engagement activities with people living in the global North. NGOs deconstruct and satirise development fundraising adverts: the 'caring' celebrity, the emotive music and their use of 'African' children, but not their deelopment project work in the fild. ${ }^{72}$

Thefocus by the NGO sector to only parody theirpublic engagement work, in an effo $t$ to further engage the public, produces a communicative feedbackloop. NGOs are inviting audiences to be part of the game, using their cynicism to acknowledge the inferiority of their communications. Although the humorous narratives address public cynicism, the social relationship between the global North and people living in poverty remains the same. In the case of the Enough Food IF video: celebrities remain the dominant voices, the people living in poverty are not only silent but are now also invisible, and the NGOs' work in the fi ld is still promoted as providing the gift of clean water, sanitation, education and, more generally, 'saving people's lives'. Theagency to be the comedian, and to tell the joke, holds implicit power and often the same framework of stereotypes are used withoutsubversion. People living 
in poverty are imagined, as in the Enough Food IF video, as passive, hungry and helpless - in need of campaigners in theUK.

John Cameron argues that in the context of low levels of public engagement in the global North with issues of global injustice, the strategic use of humouris a risk worth taking. ${ }^{33}$ However, I argue that the current use of humourin humanitarian communication defl cts attention towards celebrating a temporary subversion. Humanitarian NGOs' adoption of humourin the context of their public engagement work can be understood in relation to Mikhail Bakhtin's discussion of the carnival as folk-humour For the carnival only suspends domimant hierarchies, it is a 'celebrated temporary liberation from the prevailing truth and from the established order.74 The carnival, like the humourused in NGO campaigns, does not permeate all spaces. It achieves visibility onlywhen 'permitted by the culture which is operating these hierarchies as norms, [which] leads us to see carnival's long term eff ct as constraining rather than liberating. ${ }^{75}$ Humanitarian NGOs satirise their communication practices on their own terms. While they off $\mathrm{r}$ a degree of self-deprecating humour by parodying their communication traits of starving children, celebrities and dramatic music, this rarely results in a clange in how they communicate poverty more widely.

\section{Conclusion}

While digital interactions can be archived, the rapid change in users' Facebook News Feeds contributes to NGO communication occupying only a temporal position of visibility. Thearchitecture of Facebook, in particular the algorithmicselection of the News Feed content, is both the 'gatekeeper' and 'governor' of visibility. Theimplicit ideology of Facebook to be a networkofpositive sentiments has produced a new code of conductfor NGOs. To achieve visibility, humanitarian communications need to be 'likeable', which has resulted in NGOs changing their visual communications. However, while the communication becomes visible to a wider audience, people living in poverty still remain invisible within humorous communications that rely on the same framework of sereotypes.

Time-based actions are promoted by NGOs as a 'moment' to act, which is both quickand immediate. The commercial ideology of the Facebook platform promotes transactional and numerical modes of citizenship in which public engagement is quantitatively measured by NGOs, similar to fundraising campaigns. ${ }^{76}$ In doing so, action is orientated towards 'endorsements' of NGO-produced communication, not communicative exchanges between publics or people living in poverty. Everyday practices on Facebook contribute to users 'presencing' themselves as actors within NGO campaigns. My interviewees identifi d Facebook as a space of mobilisation. The visibility of their actions, such as 'liking' and 'sharing' NGO communication, contributes to establishing support for a campaign. Users' self-expression of compassion on issues of global poverty has also taken a turn towards the 'positive' with participation being conveyed as joyful. 


\section{Notes}

1 Bond, Fast Forward: The Changing Role of UK-based INGOs (London: Bond, 2015), p. 21;S. Nah and G. Saxton, 'Modelling the Adoption and Use of Social Media by NonprofitOrganisations', New Media \& Society, 15:2 (2012), p. 295.

2 J. Lissner, The Politics of Altruism: A Study of the Political Behaviour of Voluntary Development Agencies (Geneva: Lutheran World Federation, 1977); P. Holland, What is a Child? Popular Images of Childhood (London: Virago Press, 1992); H. Lidchi, 'Finding the Right Image: British Development NGOs and the Regulation of magery', in T Skelton and T. Allen (eds), Culture and Global Change (Oxon: Routledge, 1999), pp. 88-104; S. Cohen, States of Denial: Knowing about Atrocities and Suffering (Cambridge: Polity Press, 2001); L. Chouliaraki, The Spectatorship of Suffering (London, Thou and Oaks and New Delhi: Sage, 2006); N. Dogra, Representations of Global Poverty: Aid, Development and International NGOs (Londonand New York: I. B. Tauris, 2013); K. Tester, Compassion, Morality, and the Media (Buckingham and Philadelphia: Open University Press, 2001).

3 Just TV Advert (2013) Save the Children UK, www.youtubecom/watch?v=8bKGQQZ44oI. Accessed 5 September 2015.

4 Enough Food IF (2013), http:// enoughfoodif.org. Accessed 23 January 2014

5 H. Culley, Enough Food IF Digital Insights Report, Internal Document (London,2013).

6 N. Couldry, 'Th orising Media as Practice', Social Semiotics, 14:2 (2004), p. 11.

7 N. Couldry, Media, Society, World: Social Theory and Digital Media Practice (Cambridge: Polity Press, 2012), p. 40.

8 T. Bucher, 'Want to be on the Top? Algorithmic Power and the Theat of Invisibility on Facebook', New Media \& Society, 14:7 (2012), p. 165.

9 See E. Morozov, 'From Slactivism to Activism', Foreign Policy (5 September 2009), http:// foreignpolicy.com/2009/09/05/from-slacktivism-to-activism/. Accessed 11 December 2016; S. Shulman, 'The Case Against Mass E-mails: Perverse Incentives and Low Quality Public Participation in US Federal Rulemaking', Policy \& Internet, 1:1(2009), pp. 25-53; M. White, 'Clicktivism is Ruining Leftist Activism', Guardian (12 August 2010), www. theguardian.com/commentisfree/ 2010 / aug/ 12/ clicktivism-ruining-leftist-activism. Accessed 12 December 2016.

10 C. Bassett, 'New MapsforOld?: TheCultural Stakes of "2.0”', The Fibreculture Journal, 13(2008), http:// thirteen.fibreculturejournal.org/ fcj-088-new-maps-for-old-the-cultural-stakes-of2-0/. Accessed 5 September 2015; Z. Papacharissi, 'The Virtual Geographies of Social Networks: A Comparative Analysis of Facebook, LinkedIn and A Small World, New Media \& Society, 11:12 (2009), pp. 199-220; J. Sajuria, J. Heerde-Hudson and D. Hudson, 'Tweeting Alone? An Analysis of Bridging and Bonding Social Capital in Online Networks', American Politics Research, 43:4 (2014), pp 708-38

11 M. Madianou, 'Humanitarian Campaigns in Social Media: Network Architectures and Polymedia Events', Journalism Studies, 14:2 (D13), pp 249-66.

12 F. Sayer, Public History: A Practical Guide (London and New York: Bloomsbury, 2015), p. 232.

13 A. Sedghi, 'Facebook: 10 Years of Social Networking, in Numbers', Guardian (4 February 2014), www.theguardian.com/news/ datablog/2014/feb/ 04/ facebook-in-numbers-statistics. Accessed 5 September 2016.

14 D. Boyd, 'Social Network Sites as Networked Publics: Affo dances, Dynamics, and Implications', in Z. Papacharissi (ed.), Networked Self: Identity, Community, and Culture on Social Network Sites (New York and Oxon Routledge, 2010), pp. 39-58. 
15 Zuckerberg cited in C. Fuchs, Social Media: A Critical Introduction (London, Thou and Oaks and New Delhi: Sage, 2014), p 188, my emphasis.

16 Cited in M. Rundle, 'Zuckerberg: Telepathy is the Future of Facebook', WIRED (1 July 2015), www.wired.co.uk/article/facebook-zuckerberg-qa-the-future. Accessed 5 September 2016.

17 C. Gerlitz and A. Helmond, 'TheLike Economy: Social Buttons and the Data-Intensive Web', New Media \& Society, 15:8 (2013), p. 25.

18 B. Carter, The Like Economy: How Businesses Make Money with Facebook (Indiana: Que Publishing, 2011); Gerlitz and Helmond, 'The ike Economy'.

19 Fuchs, Social Media, p. 160.

20 Enough Food IF Facebook Page (5 March 2013): an image of cat holding an 'If' budget briefcase, www.facebook.com/Enoughfoodif/. Accessed 23 January 2014

21 Cited in W. Oremus, 'You Can't Dislike Th s Article', Slate (15 December 2014), www.slate. com/articles/technology/future_tense/2014/12/facebook_dislike_button_why_mark_ zuckerberg_won_t_allow_it.html. Accessed 5 September 2016.

22 Cited in Rundle, 'Zuckerberg: Telepathy is the Future of Facebook'.

23 E. McCann, 'Facebook Working on a "Dislike Button", Zuckerberg Says', Guardian (15 September 2015), www.theguardian.com/technology/2015/sep/ 15/facebook-dislike-buttonmark-zuckerberg. Accessed 5 September 2016.

24 Oremus, 'You Can't Dislike Ths Article'.

25 N. John, 'Sharing and Web 2.o: The Emergence of a Keyword', New Media \& Society, 15:2 (2012), p. 176.

26 Fuchs, Social Media, p. 151

27 Gerlitz and Helmond, 'The ike Economy', p. 1349.

28 Gerlitz and Helmond, 'The ike Economy', p. 1361

29 Wolens, Facebook spokesperson, cited in G. Shih, 'Google Services Should Not Require Real Names: Vint Cerf', Reuters (5 March 2013), www.reuters.com/article/us-google-namesidUSBRE9240HS20130305. Accessed 5 September 2016.

30 T. Poell and J. V. Dijck, 'Social Media and Activist Communication', in C. Atton (ed.), The Routledge Companion to Alternative and Community Media (Oxon and New York: Routledge, 2015), p. 534.

31 K. N. Hampton, L. S. Goulet, L. Ranie and K. Purcell, Social Networking Sites and Our Lives: How People's Trust, Personal Relationships, and Civic and Political Involvement and Connected to Their Use of Social networking Sites and other Technologies (Washington, DC: Pew Research, 2011).

32 Hampton et al., Social Networking Sites.

33 Poell and Dijck, 'Social Media and Activist Communication', p. 533.

34 Bucher, 'Want to be on theTop?'

35 L. Backstrom, 'News Feed FYI: A Window Into News Feed', Facebook Business (2013), www. facebook.com/business/news/News-Feed-FYI-A-Window-Into-News-Feed. Accessed 5 September 2015.

36 M. Foucault, Discipline and Punish: The Birth of the Prison, trans. A. Sheridan (New York: Vintage, 1977), p. 205.

37 Bucher, 'Want to be on the Tp?', p. 1174.

38 M. de Certeau, The Practice of Everyday Life, trans. S. Rendall (Berkeley, Los Angeles and London: University of California Press, 1984), p. 92.

39 De Certeau, Practice of Everyday Life, p. 92.

40 Although embedded links within Facebook have the potential for users to experience an 'elevated' view of a subject by following the linkto an external platform, similar to the potential 
for Twitter to contribute to a discussion not by the 140-character post but by an embedded link to a site.

41 J. Dean, 'Communicative Capitalism: Circulation and the Foreclosure of Politics', Cultural Politics, 1:1 (2005), pp. 51-74; L. Chouliaraki, 'Post-Humanitarianism: Humanitarian Communication Beyond a Politics of Pity', International Journal of Cultural Studies, 13:2(2010), pp. 107-26; L. Chouliaraki, The Ironic Spectator: Solidarity in the Age of Post-Humanitarianism (Cambridge and Malden, MA: Polity Press, 2013); Madianou, 'Humanitarian Campaigns in Social Media'.

42 Chouliaraki, The Ironic Spectator, p. 70.

43 L. Chouliaraki, “'Improper Distance”: Towards a Critical Account of Solidarity as Irony', International Journal of Cultural Studies, 14:4 (2011), p 370.

44 R. Hassan, 'Network Time and the New Knowledge Epoch', Time \& Society, 12:2-3 (2003), p. 229. See also N. Th ift, 'TheMaking of a Capitalist Time Consciousness', in J. Hassard (ed.), The Sociology of Time (London: Macmillan, 190), pp. 105-29.

45 K. Tester, Humanitarianism and Modern Culture (University Park: Pennsylvania State University Press, 2010), p. 34.

46 A. Gramsci, Selections from the Prison Notebooks, ed. and trans. Q. Hoare and G. Nowell-Smith (London: Lawrence \& Wishart, 1971),p. 419, cited in Tester, Humanitarianism and Modern Culture, p. 8.

47 Dean, 'Communicative Capitalism', p. 58.

48 Dean, 'Communicative Capitalism', p. 58.

49 V. Barassi, Activism on the Web: Everyday Struggles Against Digital Capitalism (New York and Oxon: Routledge, 2015), p. 15.

50 Couldry, 'Th orising Media as Practice', p. 121;A. Swidler, 'What Anchors Cultural Practices', in T. Schatzki, K. Knorr Cetina and E. von Savigny (eds), The Practice Turn in Contemporary Theory (London: Routledge, 2001),p. 74.

51 Swidler, 'What Anchors Cultural Practices', p. 74.

52 Z. Papacharissi, Affective Publics: Sentiment, Technology and Politics (Oxford and New York: Oxford University Press, 2015), p. 96.

53 Z. Papacharissi, 'The Internet as a Public Sphere', New Media Society, 4:1 (2002), pp. 9-27; Papacharissi, 'The Virtual Geographies of Social Networks', p. 210, drawing on E. Goffman, Stigma: Notes on the Management of Spoiled Identity (New York: Simon \& Schuster, 1963).

54 Papacharissi, 'The Virtual Geographies of Social Networks', p. 210; S. Orgad, Media Representation and the Global Imagination (Cambridge and Malden, MA: Polity Press, 2012), p. 157; L. van Zoonen, 'From Identity to Identific tion: Fixating the Fragmented Self', Media, Culture \& Society, 35:1 (\$13), pp 44-51.

55 Couldry, Media, Society, World, p. 48, 50.

56 W. L. Bennett and A. Segerberg, 'The Logic of Connective Action: Digital Media and the Personalization of Contentious Politics', Information, Communication \& Society, 15:5 (2012), p. 744 .

57 van Zoonen, 'From Identity to Identific tion'.

58 Twibbon,Free Campaigns, 2015,https:// twibbon.com/freecampaigns. Accessed 11 December 2016.

59 A survey of 186 Australian blood donors conducted by Kathleen Chell and Gary Mortimer identifi $\mathrm{d}$ virtual tokens, such as the Twibbon, are perceived as a reward for altruistic behaviour See 'Investigating Online Recognition for Blood Donor Retention: An Experiential Donor Value Approach', International Journal of Nonprofit and Voluntary Sector Marketing, 19 (2014),pp. 143-63. 
60 Boyd, 'Social Network Sites as Networked Publics'.

61 Couldry, Media, Society, World, p. 50.

62 M. Warner, Publics and Counterpublics (New York: Zone Books, 2002), p. 54.

63 Chouliaraki, The Ironic Spectator, p. 17.

64 Chouliaraki, 'Post-Humanitarianism'; Chouliaraki, The Ironic Spectator.

65 J. Cameron, 'Can Poverty be Funny? The Serious Use of Humour as a Strategy of Public Engagement for Gldal Justice', Third World Quarterly, 36:2 (2014), p 286.

66 Africans forNorway, www.youtubecom/watch?v=olLqyuxm96k. Accessed 5September 2015.

67 What Has Aid Ever Done For Anyone? (2013) Enough Food IF, www.youtubecom/ watch? $\mathrm{v}=$ AlKaNJzHdF0. Accessed 5 September 2015.

68 S. Henson, J. Lindstrom and L. Haddad, with R. Mulmi Public Perceptions of International Development and Support for Aid in the UK: Results of a Qualitative Enquiry (Brighton: Institute of Development Studies, 2010), p. 3.

69 Chouliaraki, “'Improper Distance”', p. 374.

70 T. Hobbes, Leviathan (Oxford: Clarendon Press, 1965 [1651]), p. 45; Hobbes cited in R. C. Solomon, True to Our Feelings: What Our Emotions are Really Telling Us (Oxford and New York: Oxford University Press, 2007), p. 80.

71 R. C. Solomon, 'Are the The Stooges Funny? Soitanly!' in K. Higgins (ed.), Aesthetics in Perspective (New York: Harcourt Brace \& Co, 1996), p. 609.

72 The Feel Bad Four (2012), Sightsavers, www.youtubecom/watch?v=goIDLArYsK0. Accessed 5 September 20 15; Ricky Gervais (2007), ComicRelief/ BBC, www.youtubecom/ watch?v=5DIRjecItw. Accessed 5 September 2015; Drive Aid (2012), ActionAid UK, www. youtubecom/watch?t=4\&v=4n3uD5iQP0. Accessed 5 September 2015; Let's Save Africa! (2013), SAIH Norway, www.youtubecom/watch? $\mathrm{t}=87 \& \mathrm{v}=\mathrm{bbqA608}$ _WC0. Accessed 5 September 2015.

73 Cameron, 'Can Poverty be Funny?', p. 286.

74 M. Bakhtin, Rabelais and His World, trans. H. Iswolsky (Bloomington and Indianapolis: Indiana University Press, 1984), p. 10.

75 S. Purdie, Comedy: The Mastery of Discourse (Toronto: University of Toronto Press, 1993), p. 126.

76 Culley, Enough Food IF Digital Insights Report.

\section{References}

Backstrom, L., 'News Feed FYI: A Window Into News Feed', Facebook Business (2013), www. facebook.com/business/news/News-Feed-FYI-A-Window-Into-News-Feed. Accessed 5 September 2015.

Bakhtin, M., Rabelais and His World, trans. H. Iswolsky (Bloomington and Indianapolis: Indiana University Press, 1984).

Barassi, V., Activism on the Web: Everyday Struggles Against Digital Capitalism (New York and Oxon: Routledge, 2015).

Bassett, C., 'New Maps for Old? The Cultural Stakes of "2.0"', The Fibreculture Journal, 13 (2008), http:// thirteen.fibreculturejournal.org/ fcj-088-new-maps-for-old-the-cultural-stakes-of-20/. Accessed 5 September 2015.

Bennett, W. L. and A. Segerberg, 'The Logic of Connective Action: Digital Media and the Personalization of Contentious Politics', Information, Communication \& Society, 15:5(2012), pp. 739-68. 
Bond, Fast Forward: The Changing Role of UK-based INGOs (London: Bond, 2015).

Boyd, D., 'Social NetworkSites as Networked Publics: Affo dances, Dynamics, and Implications', in Z. Papacharissi (ed.), Networked Self: Identity, Community, and Culture on Social Network Sites (New York and Oxon Routledge, 2010), pp. 39-58.

Bucher, T., 'Want to be on the Top? AlgorithmicPower and the Th eat of Invisibility on Facebook', New Media \& Society, 14:7 (2) 12), pp. 1164-80.

Cameron, J., 'Can Poverty be Funny? The Serious Use of Humour as a Strategy of Public Engagement for Glbal Justice', Third World Quarterly, 36:2 (2014), pp 274-90.

Carter, B., The Like Economy: How Businesses Make Money with Facebook (Indiana: Que Publishing, 2011).

Chell, K. and G. Mortimer, 'Investigating Online Recognition for Blood Donor Retention: An Experiential Donor Value Approach', International Journal of Nonprofit and Voluntary Sector Marketing, 19 (2014), pp 14-63.

Chouliaraki, L., The Spectatorship of Suffering (London, Thou and Oaks and New Delhi: Sage, 2006).

Chouliaraki, L., 'Post-Humanitarianism: Humanitarian Communication Beyond a Politics of Pity', International Journal of Cultural Studies, B:2 (2010), pp. 107-26.

Chouliaraki, L., “'Improper Distance”: Towards a Critical Account of Solidarity as Irony', International Journal of Cultural Studies, 14:4 (2011), pp 363-81.

Chouliaraki, L., The Ironic Spectator: Solidarity in the Age of Post-Humanitarianism (Cambridge and Malden, MA: Polity Press, 2013).

Cohen, S., States of Denial: Knowing about Atrocities and Suffering (Cambridge: Polity Press, 2001).

Couldry, N., 'Th orising Media as Practice', Social Semiotics, 14:2 (D04), pp. 115-32.

Couldry, N., Media, Society, World: Social Theory and Digital Media Practice (Cambridge: Polity Press, 2012).

Culley, H.,Enough Food IF Digital Insights Report, Internal Document (London,2013).

Dean, J., 'Communicative Capitalism: Circulation and the Foreclosure of Politics', Cultural Politics, 1:1 (D05), pp 51-74.

de Certeau, M., The Practice of Everyday Life, trans. S. Rendall (Berkeley, Los Angeles and London: University of California Press, 1984).

Dogra, N., Representations of Global Poverty: Aid, Development and International NGOs (London and New York: I. B. Tauris, 2013).

Foucault, M., Discipline and Punish: The Birth of the Prison, trans. A. Sheridan (New York: Vintage, 1977).

Fuchs, C., Social Media: A Critical Introduction (London, Thou and Oaks and New Delhi: Sage, 2014).

Gerlitz, C. and A. Helmond 'TheLike Economy: Social Buttons and the Data-Intensive Web', New Media \& Society, 15:8 (2013), pp B48-65.

Goffman, E., Stigma: Notes on the Management of Spoiled Identity (New York: Simon \& Schuster, 1963).

Gramsci, A., Selections from the Prison Notebooks, ed. and trans. Q. Hoare and G. Nowell-Smith (London: Lawrence \& Wishart, 1971).

Hampton, K. N., L. S. Goulet, L. Ranie and K. Purcell, Social Networking Sites and Our Lives: How People's Trust, Personal Relationships, and Civic and Political Involvement and Connected to Their Use of Social networking Sites and other Technologies (Washington, DC: Pew Research, 2011).

Hassan, R, 'Network Time and the New Knowledge Epoch', Time \& Society, 2:2-3 (2003), pp 226-41.

Henson, S., J. Lindstrom and L. Haddad, with R. Mulmi Public Perceptions of International Development and Support for Aid in the UK: Results of a Qualitative Enquiry (Brighton: Institute of Development Studies, 2010). 
Hobbes, T., Leviathan (Oxford: Clarendon Press, 1965 [1651]).

Holland, P., What is a Child? Popular Images of Childhood (London: Virago Press, 1992).

John, N., 'Sharing and Web 2.o: TheEmergence of a Keyword', New Media \& Society, 15:2 (2012), pp. 167-82.

Lidchi, H., 'Finding the Right Image: British Development NGOs and the Regulation of Imagery', in T. Skelton and T. Allen (eds), Culture and Global Change (Oxon: Routledge, 1999), pp. 88-104.

Lissner, J., The Politics of Altruism: A Study of the Political Behaviour of Voluntary Development Agencies (Geneva: Lutheran World Federation, 1977).

Madianou, M., 'Humanitarian Campaigns in Social Media: Network Architectures and Polymedia Events', Journalism Studies, 14:2 (D)13), pp 249-66.

McCann, E., 'Facebook Working on a “Dislike Button”, Zuckerberg Says', Guardian (15September 2015), www.theguardian.com/technology/2015/sep/ 15/facebook-dislike-button-markzuckerberg. Accessed 5 September 2016.

Morozov, E., 'From Slactivism to Activism', Foreign Policy (5 September 2009), http:// foreignpolicy.com/2009/09/05/from-slacktivism-to-activism/. Accessed 11December 2016.

Nah, S. and G. Saxton, 'Modelling the Adoption and Use of Social Media by Nonprofit Organisations', New Media \& Society, 15:2 (2012), pp. 294-313.

Oremus, W., 'You Can't Dislike Ths Article', Slate (15 December 2014), www.slate.com/articles/ technology/future_tense/2014/12/facebook_dislike_button_why_mark_zuckerberg_ won_t_allow_it.html. Accessed 5 September 2016.

Orgad, S., Media Representation and the Global Imagination (Cambridge and Malden, MA: Polity Press, 2012).

Papacharissi, Z., 'The nternet as a Public Sphere', New Media Society, 4:1 (2002), pp. 9-27.

Papacharissi, Z., 'The Virtual Geographies of Social Networks: A Comparative Analysis of Facebook, LinkedIn and A Small World, New Media \& Society, 11:12 (2009), pp. 199-220.

Papacharissi, Z., Affective Publics: Sentiment, Technology and Politics (Oxford and New York: Oxford University Press, 2015).

Poell, T. and J. V. Dijck, 'Social Media and Activist Communication', in C. Atton (ed.), The Routledge Companion to Alternative and Community Media (Oxonand New York: Routledge, 2015), pp 527-37.

Purdie, S., Comedy: The Mastery of Discourse (Toronto: University of Toronto Press, 1993).

Rundle, M., 'Zuckerberg: Telepathy is the Future of Facebook', WIRED (1 July 2015), www.wired. co.uk/article/facebook-zuckerberg-qa-the-future. Accessed 5 September 2016.

Sajuria, J., J. Heerde-Hudson and D. Hudson, 'Tweeting Alone? An Analysis of Bridging and Bonding Social Capital in Online Networks', American Politics Research, 43:4 (2014), pp. 708-38

Sayer, F., Public History: A Practical Guide (London and New York: Bloomsbury, 2015).

Sedghi, A., 'Facebook: 10 Years of Social Networking, in Numbers', Guardian (4 February 2014), www.theguardian.com/news/ datablog/2014/ feb/ 04/ facebook-in-numbers-statistics. Accessed 5 September 2016.

Shih, G., 'Google Services Should Not Require Real Names: Vint Cerf', Reuters (5 March 2013), www.reuters.com/article/us-google-names-idUSBRE9240HS20130305. Accessed 5 September 2016.

Shulman, S., 'The Case Against Mass E-mails: Perverse Incentives and Low Quality Public Participation in US Federal Rulemaking, Policy \& Internet, 1:1 (D09), pp. 25-53.

Solomon, R. C., 'Are the Thee Stooges Funny? Soitanly!' in K. Higgins (ed.), Aesthetics in Perspective (New York: Harcourt Brace \& Co, 1996), pp. 604-10. 
Solomon, R. C., True to Our Feelings: What Our Emotions are Really Telling Us (Oxford and New York: Oxford University Press, 2007).

Swidler, A., 'What Anchors Cultural Practices', in T. Schatzki, K. Knorr Cetina and E. von Savigny (eds), The Practice Turn in Contemporary Theory (London: Routledge, 2001), pp. 74-92.

Tester, K., Compassion, Morality, and the Media (Buckingham and Philadelphia: Open University Press, 2001).

Tester, K., Humanitarianism and Modern Culture (University Park: Pennsylvania State University Press, 2010).

Th ift, N., 'The Making of a Capitalist Time Consciousness', in J. Hassard (ed.), The Sociology of Time (London: Macmillan, 990), pp. 105-29.

Twibbon, Free Campaigns (2015), https:// twibbon.com/freecampaigns. Accessed 11 December 2016.

van Zoonen, L., 'From Identity to Identific tion: Fixating the Fragmented Self', Media, Culture \&' Society, 35:1 (D13), pp 44-51.

Warner, M., Publics and Counterpublics (New York: Zone Books, 2002). 


\section{2}

\section{The corporate karma carnival: Offline and online games, branding and humanitarianism at the Roskilde Festival}

\section{Lene Bull Christiansen and Mette Fog Olwig}

In humanitarianism the popularising of causes, and the use of celebrities and media culture to do so, is a rising phenomenon. Academic writing on humanitarianism, however, tends to criticise the popular, especiallywhen it is mediated through celebrities. ${ }^{1}$ Such critiques often intersect with disapproval of the growing collaboration or crossbranding between humanitarian causes and commercial interests, e.g. via corporate social responsibility (CSR), cause-branded products or philanthropy. ${ }^{2}$ Critiques of the popular characteristically draw on various theoretical and analytical approaches, such as critical discourse analysis, Žižekian ideological critique and/or grounded critical analytics. ${ }^{3}$ Th se analyses often echo critical approaches to popular culture in media studies that, following Horkheimer and Adomo, view it as an extension of the commercialisation of culture and thus as an expression of capitalist interests rather than popuhr sentiment. ${ }^{4}$ Conversely, many contemporary media scholars see popular culture as an expression of a playful anarchic potential that elites have often feared and attempted to regulate. ${ }^{5}$ The divide in debates concerning the popularising of humanitarianism is thus to some degree focused on the question of the critical potential of 'the popular' in the media. Is it possible to harness the powers of 'the popular' and media culture in service of humanitarianism, or will 'the popubr' inevitably serve neo-colonial and commercial interests?

In this chapter, we explore the possibilities of an alternative analytical approach to these topics, based on the Russian literary theorist Mikhail Bakhtin's carnivalesque analytics. 'We wish to see the increasing use of 'popubr' forms in relation to humanitarian causes froma diff rent perspective, whichmay reveal insights into the 'popular' beyond the primarily critical traditions. Th $\mathrm{s}$ is because, as we argue, the carnivalesque has something of a double identity as being both affirmative of the status quo, and, at the same time, an embodied critique of the status quo. In our case, we examinehow the carnivalesque can function both as a form of corporate 
branding and as a means to destabilise the status quo identifi $\mathrm{d}$ with a negatively branded segment of the population. Th s means that there is a constant need to critically balance an analysis of the potentially progressive and/or problematic aspects of a popularised humanitarian event, rather than to simply criticise or praise. In order to make this point we will explore the energies that are at play in the popular 'carnival' of the Danish non-pofit usic and alture festival, the Roskilde Festival.

A second key aim of this chapter is to expand our understanding of the timespace/ place relation of the festival, or carnival, encapsulated in the notion of the festival as a chronotope, by drawing attention to the contemporary practices of adding online activities to the offline events of the festival. ${ }^{8}$ The many humanitarian, social and environmental happenings and routines generated by the festival are often communicated online. Facebook pages, blogs, Instagram, Twitter and hashtags all accompany the initiatives and events. The place of Roskilde Festival is thus expanded into cyberspace. The diff rence between the experience of lived community at Roskilde Festival, and the way that this is tied to the virtual reality of the internet, might help enhance the Roskilde Festival experience, and deepen the audience's understanding of the humanitarian issues at play. It is, however, a mediated reality that easily turns into a public relations vehicle for the humanitarian organisations, as well as corporate sponsors, that goes well beyond the physical Roskilde Festival experience. The case study that we have chosen for this chapter illumimates these diff rent trends by exploring the links between a corporate brand, festive humanitarian engagements with Roskilde Festival, and the offline-online interconnectivity of the humanitarian events.

Roskilde Festival is the largest North European culture and musicfestival and is held each summer in the outskirts of the city of Roskilde, which is ca. $30 \mathrm{~km}$ from the capital city of Denmark, Copenhagen. Thefestival prides itself on its non-profit status and its commitment to sustainability and global solidarity. In this chapter we focus on Hummd, one of the festival's many corporate sponsors and a Denmarkbased international sports clothing company. In collaboration with local NGOs, Humme participates in Roskilde Festival with brand-related happenings and has named its events 'Orange Karma' after its CSR philosophy 'Company Karma.' Orange is the signature colour of the festival chosen because of the orange colourof the biggest concert stage at the festival, which is used as the logo for the festival. We are here examining the Orange Karma events in 2013 and 2015.

\section{Case study: Orange Karma}

While ensuring a good concert programmeis of course crucial, an important component of Roskilde Festival is instilling a sense of community and there is an element of utopian vision in the history and mandate with which the festival is associated. Ths is often referred to as the 'Orange Feeling' and has been described as embracing solidarity, charity, tolerance, artistic freedom, creativity and community. ${ }^{10}$ The 
Orange Feeling infuses all aspects of the festival experience, as exemplifed by the following excerpt from Lene's fi ld notes:

While Mette has gone to fetch fl ers, I sit down to write somenotes. A couple of young guys in their late teens pass by me. One of them gently dunks the top of my head, calling out 'hey you' - I reply: 'hey there' - theyboth say 'bye bye' and walk on. I think to myself that this is a typical Roskilde Festival encounter. One would not behave like this anywhere else; approaching a total stranger, who is decidedly outsideof yourown age group, in this playful casual manner for no apparent reason. Here on this lazy afternoon in the sn, it sems perfectly natural. ${ }^{11}$

Many NGOs as well as businesses draw on the Orange Feeling, and the potential of reaching some of the more than 100,000 festival participants through various events, shops, happenings and promotions at the festival. ${ }^{12}$ Orange Karma, one of numerous platforms through which Roskilde Festival supports the promotion of environmental and social causes, is organised as a collaboration between Roskilde Festivaland Hummd. For Hummd, Roskilde Festival provides a high-profile opportunity to raise the profile of its CSR philosophy, while also, of course, increasing brand recognition. The CSR philosophy behind Humme's campaign is a carefully crafted branding strategy, which is personifi $\mathrm{d}$ by the owner and CEO of the company, Christian Stadil. In collaboration with one of the country's leading researchers in organisational change and business management, Steen Hildebrandt, Stadil shaped this philosophy inspired by his own interest in Buddhism. ${ }^{13}$ Stadil's public persona embodies Company Karma, and combines the urban cool of a fashion icon with a self-styling that is reminiscent of a Buddhist monk or even Mahatma Gandhi. ${ }^{14}$ As part of its CSR strategy, which includes a number of charities, Hummd has sponsored several sports events that are linked with good causes.

The 2013 Humme sports event examined in this chapter is a football (soccer) tournament, organised in collaboration with an organisation called 'Eir Soccer' the signific nce of the name will be explained shortly. The tournament consisted of two competitions taking place simultaneously in adjacent football fi lds. In one of the twinned tournaments female festivalgoers competed, while in the other tournament female asylum-seekers competed. Theother Hummd sports event examined in this chapter is the 2015 'Street City Games' (such as street basketball, volleyball and football), organised in collaboration with a NGO named 'GAME Denmark', or 'GAME' for short. It involved male and female festival participants and included two high-profile events: a street basketball game pitting celebrities against the Hummdsponsored basketball team, 'Stevnsgade', and a beach football game involving (male) members of the local Roskilde police force playing against (male) members of the hippie anti-establishment community 'Christiania' located in Copenhagen. As we will return to below, Eir Soccer and GAME promote humanitarianism in different ways. 
The case study is based on participant observation and the analysis of press and online representations of the Orange Karma events as well as related online materials. Online material and coverage include Facebook announcements of events, Instagram campaigns, a webpage with video reportages of the events, short videos presenting individual players from participating sports teams, and videos portraying the festive spirit of a fooball toumament.

\section{The popular as carnivalesque}

Bakhtin's ideas have been adopted by diff rent disciplines beyondliterary studies: his works have inspired, amongst others, sociologists, cultural theorists and linguists. ${ }^{15}$ In this study we apply Bakhtin's concepts to the study of humanitarian events and communication in relation to the Roskilde Festival. We have elsewhere depicted how Roskilde Festival in many respects exemplifi s Bakhtin's theory of the carnivalesque, 'where festive forms of the carnival includeparodies, dressing up in costumes, eating and drinking in abundance, satirical rendering of authority figures and an emphasis on carnal pleasures such as sexual experiences and eating. ${ }^{16}$ The energies that are at play in carnivalesque popular forms are intimately connected to bodily experiences and performances.

Two elements of the carnivalesque are worth highlighting here. First, the satire and laughter of the carnival is associated with the 'lower regions' of the body. Th re is an important duality to this; thelower regions of the enclosing body are seen as the place of birth and rebirth, and hence as the enclosing womb as well as the enclosing bodily tomb of death. They are also viewed as the place of excrement often used to mock authority figures. When used as fertiliser, however, excrement contributes to nature's rebirth. Such a duality was exemplifi d at Roskilde Festival 2015, by the Danish Agriculture and Food Council, which ran a campaign to recycle urine, via large mobile urinals, under the slogan 'Don't waste your piss. Danish farmers can turn it into beer again' ( see figure 12.1). Second, for Bakhtin the carnival constitutes a turning 'upside down' of society. Authority figures are 'fair game' for satire and normal monl codes are suspended for the duation of the canival:

We must consider again in more detail the ambivalent nature of carnival images. All the images of carnival are dualistic; they unite withinthemselves both poles of change and crisis: birth and death (the image of pregnant death), blessing and curse (benedictory carnival curses which call simultaneously for death and rebirth), praise and abuse, youth and old age, top and bottom, face and backside, stupidity and wisdom. ${ }^{17}$

Combined, these dualistic elements suggest for Bakhtin that the degradation of the exalted figures of society in carnival satire has an internal ambivalence, because this degradation also points towards a rebirth of society (literally and figuratively) passing through the lower regions of the bodyin order to be reborn. Th s means that the carnival is simultaneously satirically denigrating and (re)affirming, and thereby 


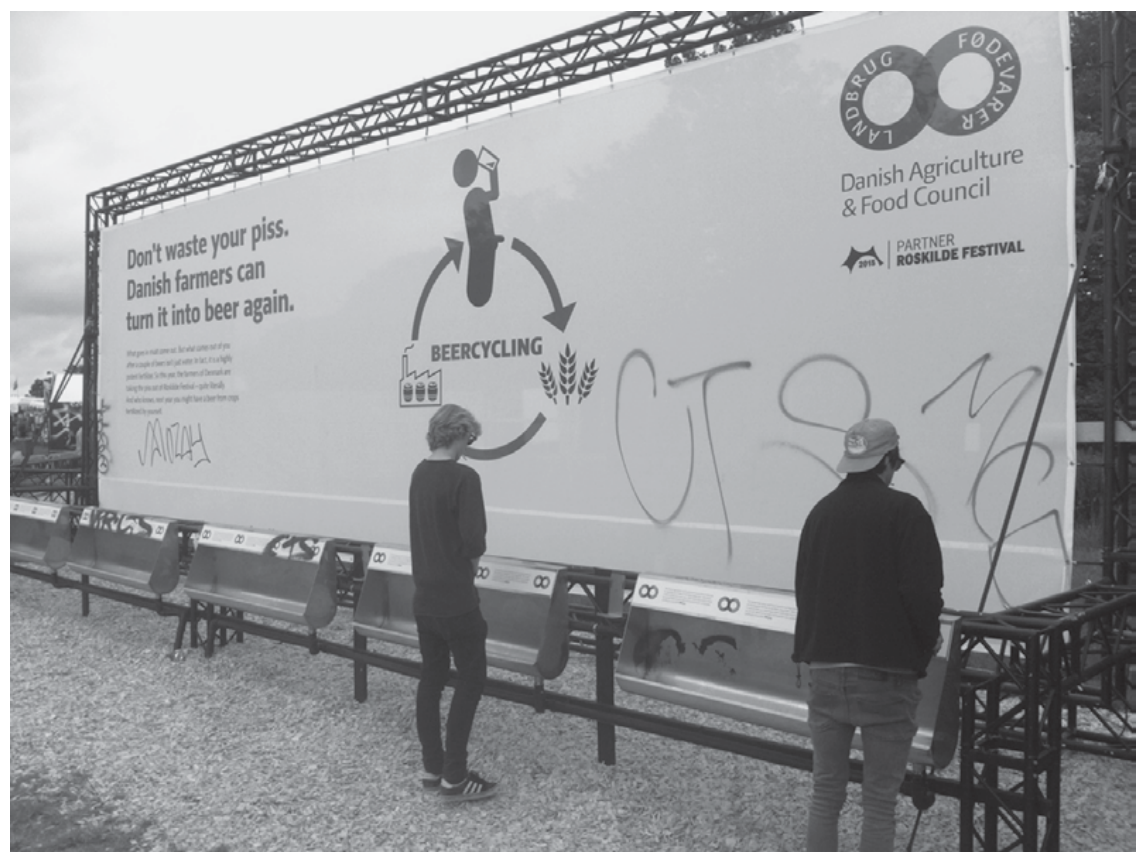

Figure 12.1 Collection of uine from the festival which Danish farmers will 'turn into beer'

can work to either revitalise existent social power structures, or to motivate their transformation. ${ }^{18}$

In our context, this duality and/or ambivalence in the carnivalesque analytics poses similar challenges. It means engaging the deeply problematic power relations behind global inequality and corporate greed that produce, for instance, the social reality of the asylum-seekers whom we encountered in the Orange Karma event. With this analytics there is a risk of over-interpreting the signific nce of embodied experiences and performances, and the regenerative powers of the carnivalesque, while underestimating the reinforcement of social power relations, which from a Bakhtinian point of view is also part of the canival.

In order to understand the relation between the festival and the social context and power relations associated with it, we propose to analyse the festival in terms of Bakhtin's concept of the 'chronotope.' The notion of the chronotope has been applied in order to understand the ways in which specific meanings, signific nce and consequences are attached to particular space/ place-temporalities. ${ }^{19}$ Bakhtin develops the concept to describe the specific time-space/ place relations that govern literary genres via the att ibutes, noms, traditions and 'worldsense' that characterise a particular genre. ${ }^{20}$ The chronotope thus governs the norms, traditions, socialites and asthetic forms linked to a particular delimited time-space/ place. 
The delimited nature of the chronotope does not indicate that it is a contained unit. The chronotope is, as per Bakhtin's overall focus on 'dialogism', intertextual in the sense that in the carnivalesque it involves a dialectic dialogue between the popular instituting of the event, which is a sociological fact, and the immaterial forces that are associated with the carnivalistic forms. ${ }^{21}$ For Bakhtin carnivalistic folklore is a particular world sense that 'possesses a mighty life-creating and transforming power, an indestructible vitality. ${ }^{22}$ Connected to this dialectic is another dialectic between space and place. Chronotope is often translated as timespace or the spatio-temporal. The Greek word 'topos', nevertheless, literally means place, notspace.

Space and place, and the relationship between them, are highly debated topics within disciplines such as geography. ${ }^{23}$ Some (positivist) geographers, according to Tuan, see place as merely a location and thus as 'subsumed under the geographer's concept and analysis of space. ${ }^{24}$ From this perspective, which tends to be associated with economicgeographers, space is a web of (commercial) nodes/locations that they term 'places'. Place is then a location within a spatial structure. For the humanistic geographer, however, place is more than mere location. It 'incarnates the experiences and aspirations of a people. ${ }^{25}$ The place of the carnival, from this perspective, can incarnate the experiences and aspirations of people in relation to a sense of community. But as we will show in our analysis of the Roskilde Festival, the place of the carnival also risks being incorporated into the media cultural branding of a global corporation through a cyber-spatial network.

The place of a carnivalesque event is important. Roskilde Festival, for example, takes (and thereby makes) place in the same spot every year, and participants in the festival get a special feeling and behave in a diff rent way than they would outside this place. The place is thus crucial to understanding the festival chronotope, and the humanitarian events' use of, and contribution to, this place are important to this understanding. With the increasing use of online communication in relation to the Roskilde Festival, however, the festival progressively expands into cyberspace. Cyberspace diff rs from place in that it is not experienced directly with all the senses, and thus the whole body Furthermore, as we will show, cyberspace, and the media culture with which it is often linked, is a mediated reality that can be carefully manicured and controlled by specific interests, in this case humanitarian and corporate communication and branding. Additionally, cyberspace is not contained spatially and temporally in the same way as the material place of the Roskilde Festival. At a diff rent time, for example, the grounds used for the festival are used for a county fair, but it is possible to continue experiencing Roskilde Festival in cyberspace long after leaving the place of Roskilde Festival. Th re is thus a continuing dialogic relationship between place and space that is manifested through the relationship between the 'offline' place of Roskilde Festival as an event, and the 'online' cyberspace of the internet. 


\section{Social soccer and basketball benefit events}

The organisation involved in arranging the Orange Karma events with Hummd in 2013 used to be called 'Sensational Football' but is presently named 'Eir Soccer' after 'a goddess and valkyrie associated with medical skill and a healing goddess. ${ }^{26}$ As the Eir Soccer website explains, the organisation employs 'soccer and the ball as a means of creating a better world' and in order to stand 'up against the severe injuries as well as gender stereotype in soccer - and support women to live a full life with soccer. ${ }^{27}$ The carnivalesque festiveness of its activities is featured prominently on the organisation's website, where a photo of happy female football players in costumeadorns the front page. ${ }^{28}$ When scrolling further down the front page, one of Eir Soccer's other activities is described: the Asylum United initiative, which includes establishing football teams for young women in Danish centres for asylum-seekers run by the Danish Red Cross. ${ }^{29}$

Themain feature in Hummd's Orange Karma area in 2013 at Roskilde Festival was a twin football tournament that took place simultaneously. One tournament comprised teams of asylum seekers, named after the diff rent asylum centres, wearing matching Hummd gear (see figure 12.3). The other overlapping tournament was made up of ordinary female festival participants who signed up in teams that were more or less created for the event. Some had chosen a silly and festive theme and name for theirteam, such as 'Puzzy Riders' or 'Girl Power and Fishermen', whereas others had more commercial themes, such as team KitKat a global candy bar brand - or team Cocio - a Danish chocolate beverage. ${ }^{30}$ The teams wore outfits matching the themes (see figure 12.4). The festive frontpage picture of Eir Soccer's website appears to be from a similar tournament of festive teams.

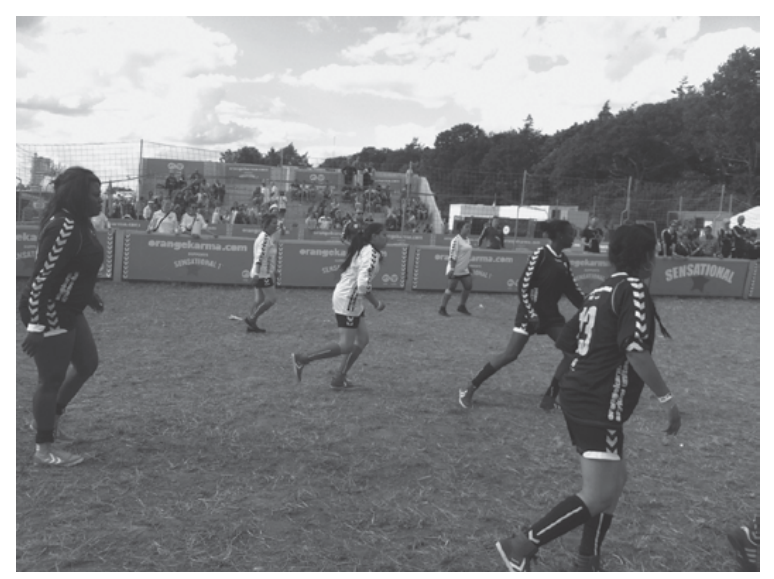

Figure 12.2 Sensational Football tournament at the Roskilde Festival 


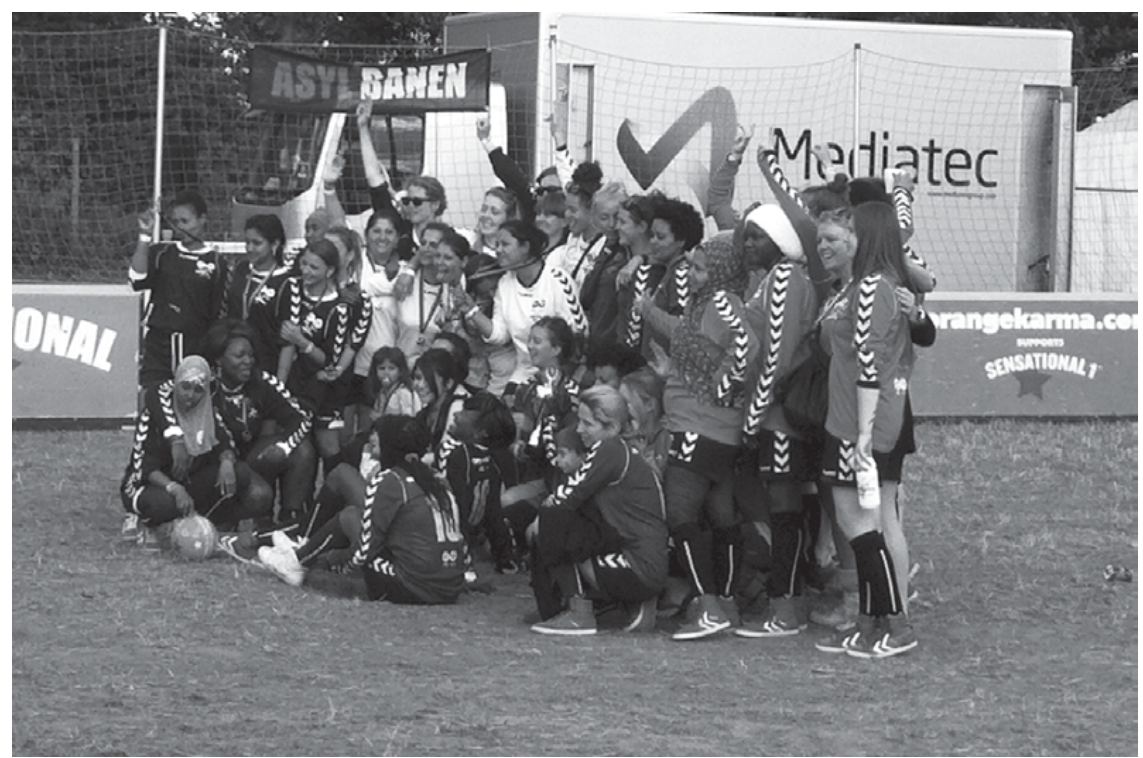

Figure 12.3 Participants in the Sensational Football toumament

Mette's fi ld notes from the 2013 festival describe how the football toumament came to our attention, and how it appeared to accidental onlookers, such as Mette who initially was looking for another humanitarian event:

In the distance I notice a crowd watching something and decide that this must be it. As I get closer I realize the crowd is watching women playing football - The Orange Karma Sensational toumament ... [The area] turns out to be filled with various Orange Karma events, communicated as: a wide range of activities during the festival that enable the festival guests to party and have fun while supporting Sensational Football's projects in Danish Asylum Centres at the same time.

[Thenext day I return to have a better look.] Thecentral part of the area consists of two fi lds and on each side of each fi ld a big crowd is enthusiastically cheering the players. Girls dressed in bizarre outfits, such as full suit tiger outfits, are waiting eagerly for their turn to play ... Each game is only six minutes, so by the timeI figure out what the team is called, a new oneenters. Someonein the crowd yells: 'We are all rooting forwhoever wins!'

... I notice that the audience is very diverse. One couple is sitting next to me, silently watching the game, smiling. Several groups of rowdy guys are cheering loudly and happily. Even the bottle and can collectors who come to the festival to make moneyoccasionally take a break to watch the game. Behind me are three girls with fake noses hanging around theirnecks. It must be part of theirteam outfit... At one point I hear one of them saying 'Thetoumament is a really great place to advertise - I can see that Cocio has put together a team!' Her friend agrees and responds: 'I saw that there is a team called KitKat!' 


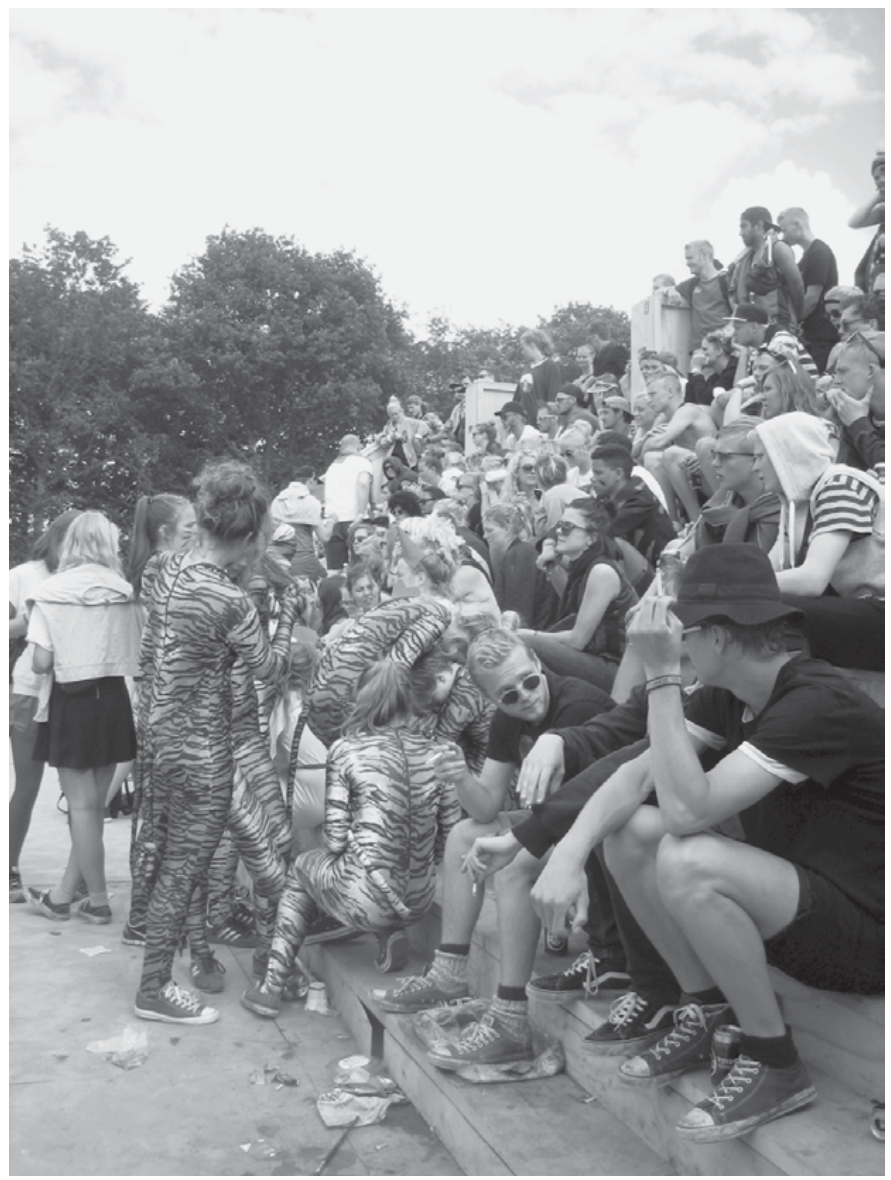

Figure 12.4 Spectators and participants in the Snsational Football toumament

... Two very diff rent all-femaleteams now appear on thefi ld: 'Team Kongelunden' and 'Team Jelling' - names of Danish asylum centres. Theyare diff rent in the sense that they are wearing Hummd outfits and not fake noses or tiger tails. I hear some people from the crowd comment that they are probably very good at playing football. Six minutes later 'Team Kongelunden' has won the game and 'Team King Henrik's Harem' and 'Team Camp Tiger Kitten' enter the fild. ${ }^{31}$

In an attempt to better understand the event, Mette spent some time reading the diff rent posters advertising and explaining the events, looking at the diff rent Orange Karma booths that were placed in the area, and asking the booth managers about the event. She was fi ally enlightened when she walked over to an organised bonfie: 
a sign reads 'SUPPORT ASYLUM UNITED: marshmallows, banana, popcorn and snobrød over fi e - 10 Danish crowns [approximately $£ 1$ ] ${ }^{32} I$ decide to ask the woman raking the fi e if she can tell mea bit more aboutthe event. She explains that it has taken place at Roskilde Festival for two years and keeps getting bigger. It is very popular which is probably why the festival continues to let them do it. Sensational football, she elaborates, has existed for ten years and used to have its toumament at a square in downtown Copenhagen where inner city kids can play street basket. Four years ago Sensational Football started Asylum United, and two years ago it came to Roskilde Festival ... When I comment on the elaborate outfits, she explains that participants can win a prize for best outfi, as well as best karma and best sensation. She is not sure what the diff rence is between karma and sensation, but it is something aboutcreating the best atmosphere when playing.

... Across from the bonfie is a nail bar. She tells me that it is run by girls from the asylumcentres and that it was the girls' idea to do it. I walk over, curious, and see many girls doing the nails and hair of men as well as women [see figure 12.5]. Everyone is smiling, chatting and hugs are distributed at regular intervals. ${ }^{33}$

As indicated in the above quote, it is unusual for this kind of event to take place repeatedly at Roskilde Festival, and especially in such a prominent location. Usually

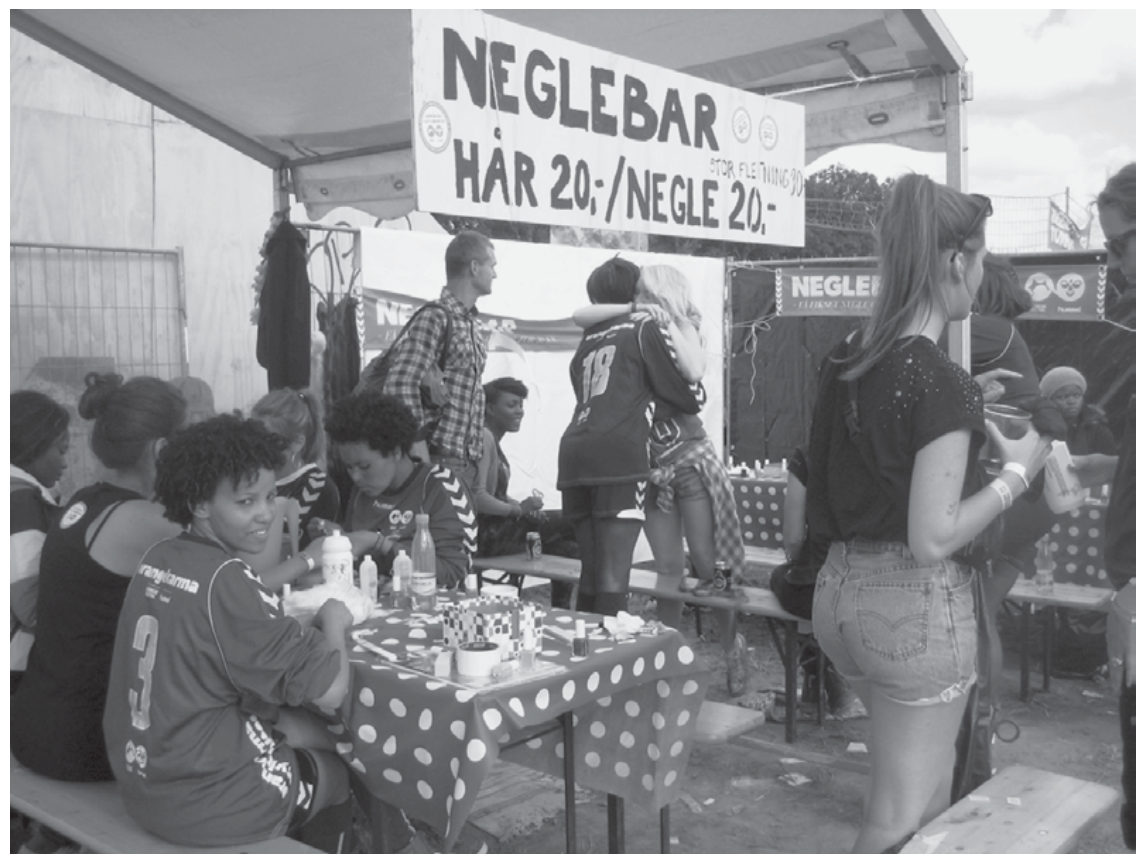

Figure 12.5 Orange Karma booth where festivalgoers and asylum-seekers can meet and talk during a mil or hair treatment 
Roskilde Festival makes a point of enabling diff rent causes and organisations to gain exposure at the festival. Indeed, as it turned out, Eir Soccer was eventually onlyinvolved for one more year in the Orange Karma events. When we returned in 2015 , the asylum teams and girls in costumes had been replaced by a diff rent event. Street basketball, volleyball and football toumaments had been set up as part of the Orange Karma area, and the NGO GAME was now collaborating with Hummd in the organising of the events. GAME promotes health and civic participation by supporting and organising street sports and training programmes amongst, for example, marginalised urban youth and children with mental illnesses. ${ }^{34}$ TheNGO has won several prizes, including one for its contribution to integration in Denmark, and has expanded its operations to Lebanon with plans to further expand to eight more countries before $2020 .{ }^{35}$

As part of the 2015 Orange Karma activities participants in the festival could sign up for tournaments and during each game it was possible to 'exchange fighting spirit for karma' since Hummd donated a ball to GAME for every goal that was scored.$^{36} \mathrm{~A}$ total of 1,162 balls were eventually donated..$^{37}$ Two of the most highly advertised and popular events, as mentioned, were a street basketball game between the successful Copenhagen-based basketball club Stevnsgade and a team of Danish celebrities, and a beach football game between the Roskilde police force and the hippie anti-establishment community of Christiania.

When we made observations during the GAME celebrity match in 2015, we were struck by the scant mention of both the GAME organisation and its mandate, as illustrated by this extract from Lene's fi ld notes:

When I arrive at the Orange Karma area shortlyafter 2 pmno basketball match is taking place. We had anticipated that it would have already started, and I try to glean some information from the large screen, which is mounted above the basketball court. The screen flashes the GAME slogan 'we love asphalt' and runs promotion videos such as a promotion video for GAME, mostly consisting of shots of kids playing diff rent street sports, and another promotion video for Orange Karma and GAME's collaboration, which calls on the festivalgoers to 'Change the world at 108 Decibel' and to 'join the GAME and support vulnerable children and young people' [see figure 12.6]. Th s leaves me wondering which vulnerable children they are referring to, and where one can join the GAME - is it here, or somewhere else? Occasionally a program for the day appears on the screen - but the celebrity match is not on, which frustrates me because this is what I'm here for. I do not have a smartphone with me, so eventually I call Mette, who has Internet access and can confi $m$ that it has been announced online as sarting at $3 \mathrm{pm}$

... After the celebrity game, a commentator, speaking over the loudspeaker, initiates a game of hoops, which is open to everyone. I am pondering why there has been no mention of GAME by the commentator at all throughout the two hours that I have been observing the matches, since there is such a strong visual presence of GAME's logo on the screen. I have been given a fl er, though, which promotes some 


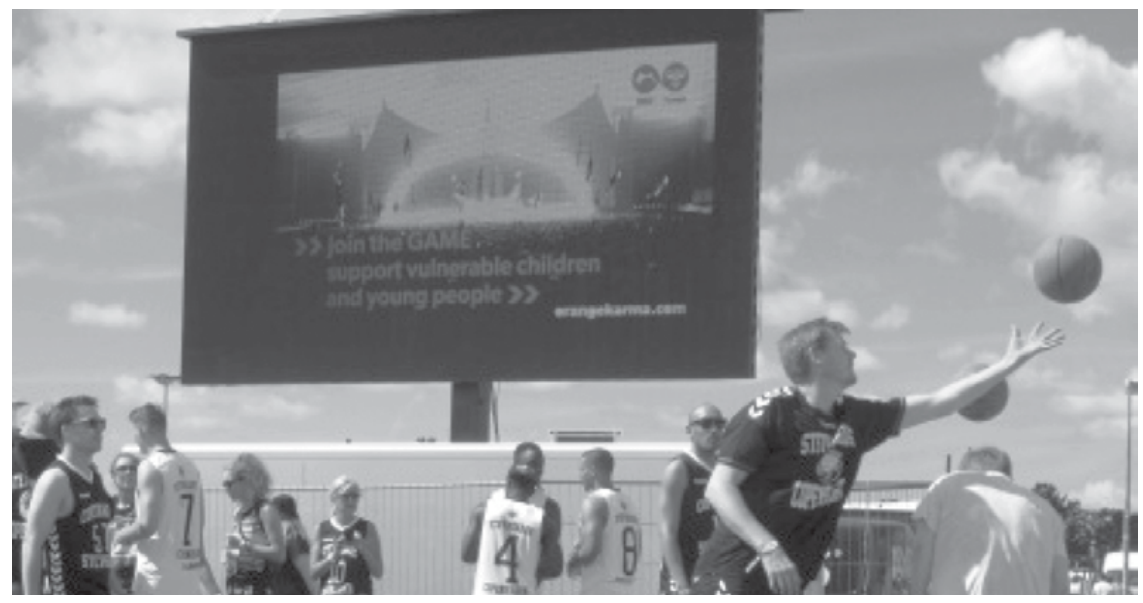

Figure 12.6 Screen showing GAME/Orange Karma promotion materials during basketball game 2015

GAME activities: a basketball event in Odense (Denmark's third largest city) and one in Copenhagen. The fl er, however, does not provide any information about what GAME is. I leave the Orange Karma area feeling more confused than when I arrived. ${ }^{38}$

It turned out that GAME relied heavily on online promotion of the organisation. In fact, it was difficult, or nearly impossible, to attain any offline information from the organisation, even when we approached the Orange Karma infomation booth. Rather, Orange Karma and GAME logos adorned posters, banisters and a large screen, which was mounted above the basketball court and, as described above, showed promotional videos presenting mostly images of street sports, and very little text beyond slogans (see figure 12.7) and an announcement of the week's program. While it was sometimes difficult to comprehend the full dimensions of the events while theywere taking place withoutbeing online, the interplay between onlineand offline activities had the potential of creating a whole diff rent experience. Th s leads us to analyse the two as interconnected, with the online presentations not onlyproviding background information for the offline activities during the festival, but also figuring as an integral part of the offline experience. We therefore analyse the online representations in relation to the festival chronotope.

\section{Online representations and offline experiences}

The Orange Karma events at the Roskilde Festival in 2013 and 2015 included both online and offline activities. Part of the 2013 Sensational Football/ Eir Soccer online representations consisted of videos from the diff rent years, where the toumament 


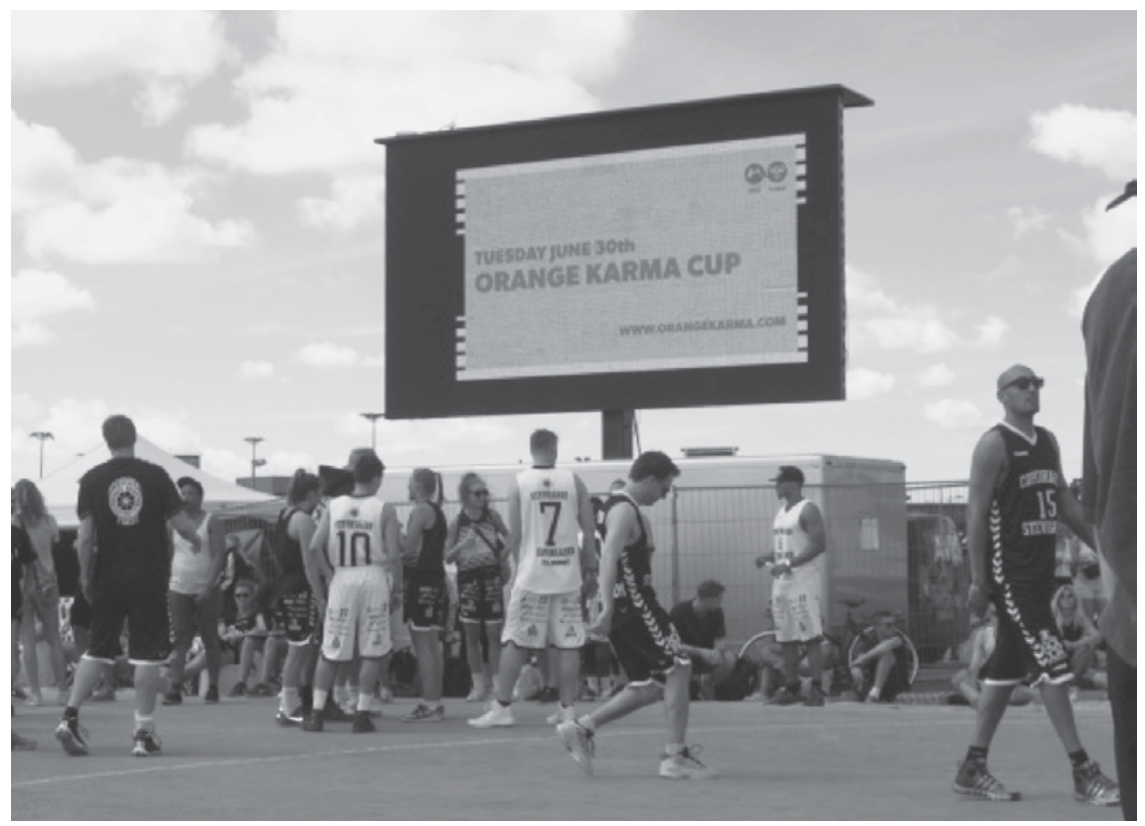

Figure 12.7 Players warming up for the elebrity basketball game

has taken place, which highlighted the festive spirit. ${ }^{39}$ Alongside these videos, the Hummd YouTube channel also presented documentaries on the young asylumseekers participating in the tournament. Th se depict the daily struggle of being refugees in Denmark, how the young people came to live in the asylum centres and the various ways in which the football teams provide a free space where their daily troubles could be forgotten and a sense of community and belonging could be experienced. ${ }^{40}$

The videos celebrating the tournament spirit are underscored by pop music, they have bright colours and sunshine and they show partying and playful people dressed in silly costumes, mixing and playing with the asylum-eekers in football uniforms. Thevideos portraying the toumament as a free and happy space of community, togetherness and joy stand in stark contrast to the videos depicting the lives of the asylum-seekers. An example of this is a video reportage that features Midheta and Mihreta. In the fi st shot of the video, they (along with a third unmamed young woman) are shown in an empty, darkhallway, with theirbacks turned to the camera. Theyare standing on a small balcony, looking out into the light green outdoors. The narrative of this video reportage is relatively simple, the film is no more than twoand-a-half minutes long, but it clearly shows a situation in which their daily lives are 'tedious' and the opportunity to play football is the light at the end of the tunnd (symbolically rendered via the opening shot of the video). The video then goes on 
to present interviews with the two young women, interspersed with shots from a training session:

We were in Copenhagen - we slept there - and I thinkthat it was fun, also that we were outsidethe centre for a bit, withoutour parents, and withoutour brother. We did not win; we were second place or so. We were just out from the centre, so we kind of forgot it a littlebit. It [the centre] becomes a littleboring, because we have been here so long.

[A song with English lyrics plays, while the young women are shown at a training match in a gym]: 'Shaking, making. Something new. Already made by someone else. Trying to make a living, stop the spinning wheel of life.' [Thelast shot from the gym shows small children, watching the game, smiling and waving at the camera. $]^{41}$

The narrative describes the football training and matches, which take place outside the asylum centre, as the catalyst for the girls moving from a dark and boring existence at the centre, to a fun and community filled life of football. Getting away from the dark and boring life of the asylum centre is also at the heart of a corresponding video reportage, featuring Nancy.

Nancy, who is fifteen years old, says: 'I think that it helps one to get away from some of the stuff. It's like, being together with others rather than - like - sitting insideat home. ${ }^{3 / 2}$ Nancy describes how a friend invited her to participate in the team, and how playing can also be a littlehard, but that she is now in love with football. She is shown in her homeenvironment, where she is hanging out with a friend in typical teenage fashionand reading books on her bed beneath posters of the singer Justin Bieber, and at the training ground, where she is shown playing with the ball with her team mates. Thevideo portrays, on the one hand, a typical teenager, and on the other hand, a life which is very diff rent from that of an ordinary Danish teenager what makes Nancy part of the community is football.

Similar videos are found on the GAME website. As part of the description of a particular programme, 'Support on the asphalt', a video features a young girl, Annika, and her mother, Birgitte. The mother narrates in voiceover/filmed interview, while we follow the two of them, accompanied by a younger brother, as they take part in a parkour training session at a GAME gym. The setup of the video echoes the Hummd videos by moving from grey/ dark everyday life to a bright and lit-up gym setting:

Birgitte: Annika has always been particularly sensitive - that was what I called it we kind of gave it our own name. When she turned ten she suddenlybecame really, really ill and unfortunately it took more than a year for her to get a diagnosis and get help. Her diagnosis now is OCD [Obsessive Compulive Disorder], she is now medicated and functions well, but she has faced a lot of difficulty at various periods of time.

[A project leader from GAME explains that the aim of the project is to create sports for everyone, they do this at the street level, but also by focusing on groups that 
often do not participate in organised sports. The 'head coach of the street movement' describes how the training programme is constructed to allow anyone to participate with posifve results.]

Birgitte: We had hardly left the gym the fi st time, before Annika said 'wow, it would be even better if it lasted two hours' and her little brother said 'yea - two times a week would also be really great'. I was really like 'what has happened to my children!' - and it really is an amazing leap. The good days are parkour days. It is so positive and nice and you do it together and you play. It has such a good feeling, and I thinkthis is what makes a diff rence for us. ${ }^{43}$

Th s narrative depicts the GAME parkour training as vitally important to the mental and physical health of the kids who come there. The visual markers of movement from dark tones and sombre moods to light and celebratory moods underscore the transformative properties of the GAME programme.

In both the GAME programme and the Sensational Football/Eir Soccer programmethere is a contrast between the videos that present the narratives of 'beneficiaries' and the videos of the football tournament and festival activities. Thefestival footage depicts the colourful and joyful activities during the tournaments and games of the festival in sharp contrast to the darkness and dullness of the asylum centres and the difficult daily life of living with illness. In the festive videos, we see the celebrities and spectators of the basketball match, the imaginative and colourful costumes of the diff rent football teams as well as bodies dancing, drinking, playing, falling, colliding with each other, and embracing after a win. ${ }^{44}$ Read together, the videos about the benefi iaries and the videos celebrating the community atmosphere of the festival can be seen to display a dichotomy involving detachment and excludedness versus community and includedness. Thefestival and the tournament constitute breaks from the restraints of everyday life. The intertextual meaning created between these videos represents the Sensational Football/Eir Soccer and GAME events at Roskilde Festival as radically diff rent places that are infused with the 'Orange Feeling'. In this chronotope a new community of fun is created where hierarchicaldivides such as citizenship language, culture, nationality and diagnosis were temporarily suspended. Having a party while supporting the marginalised is the logic behind the Orange Karma events. Ths is depicted in the description, which accompanies the video reportage of Midheta and Mihreta on buTube:

In the very heart of the Onnge Karma collaboration you find arma Asylum United.

All the diff rent Orange Karma activities at Roskilde Festival contribute to the shared ambition of creating moments of peace and friendship for women in Danish asylum centres.

With Sensational Football as the driving association behind the projects, we use football and music as tools for change in six Danish asylum centres. More than 200 female asylum seekers have practiced and foundunity and a lot of smiles in our sport and music activities. 
At the festival, teams from each centre will participate in the football toumament but also party and dance together with festival guests. ${ }^{45}$

During the two years that had passed between the 2013 football tournament and the 2015 GAME events there had been a great increase in the use of smartphones (especially at the festival site, where recharging facilities had become readily available, enabling continuous access to the internet) to the extent that many activities throughoutthe festival have become online/ offline integrated. As we have seen, the connection between online and offline participation in the events themselves was essential to experience the GAME events - indeed we literally had to go online in order to even know when the event would take place. Particularly the Instagram feed of GAME extends the organisation's ability to portray itself as simultaneously hip and cool as well as socially active and engaged. With the popularisation of humanitarianism social media is increasingly used and it has become commonto promote humanitarian causes online through images and videos enabling consumers to show their interest and concern through 'likes' and 'sharing' such causes. It had thus in some ways become 'natural' for the festival participants to 'meet' the benefi iaries online in 2015, whereas they encountered the asylum-seekers in person in 2013. Being online had become the norm in 2015, whereas being offline, and thus 'turned off', had come to denote being defi ient or lacking, and thus an abnomal situation. So, simply put - our offline experience of the GAME celebrity basketball game was only half - we were meant to be tuned into it online as well as show up in order to participate. Thechronotope of the Roskilde Festival, and the Orange Karma events, was thus extended beyond the time-place of the festival grounds/Orange Karma area via the onlne representations and participation in the erents.

\section{Conclusion: Orange Karma as corporate utopia}

When people dress up in costumes and associate more freely with strangers than one wouldoutsidethefestival chronotope, new norms and social imaginaries are created with which Humme can be associated. Theorganisations Sensational Football/ Eir Soccer and GAME add to this. Sensational Football/ Eir Soccer did so with its practice of creating spaces for enacting equality and bodily proximity between people who in their everyday lives are separated by virtue of their diff ring legal status. The festival in 2013 happened well before the sudden media focus on refugees spurred by the 2015 large-scale movement of refugees to Europe. At the time, the toumament therefore enabled the Danish population to become better acquainted with asylum-seekers and to see how diff rent the asylum-seekers playing on the teams could be. Some were black, some white; some wore headscarves, others had high ponytails. Additionally, participants in the events were introduced to the diff rent asylum centres by virtue of the team names. Furthermore, through the asylumseeker teams the women shared something besides being asylum-seekers - football. 
Finally, the fact that the toumament of both the asylum-seekers and the regular festival participants only comprised women challenged the European norm that it is men who play football. GAME similarly played with turning things on theirhead by letting bitter rivals such as the hippie anti-establishment community of Christiania and the police play against each other. The organisations thereby also acted as coimaginers of new social noms.

What the two events that we have studied here share is the involvement of the corporate sponsor Hummd via Orange Karma. Thecorporate philosophy of Company Karma places Hummd as a not-so-silent partner with the two organisations GAME and Sensational Football/ EirSoccer. ${ }^{46}$ Not onlydoes Humme get positive branding for its corporate philosophy via the collaboration, it also promotes the marketing of its products An Orange Karma shoe and clothing line, with the characteristic orange colourof the festival, has thus been launched and sold in the Orange Karma area and at a Hummd shop in the concert area (see figure 12.8). The profits go to good causes while simultaneously promoting the Hummd brand.

TheCEO of Hummd, Christian Stadil, embodies the Karma branding of Hummd to such an extent that his mere presence at the festival was described by onelocal tabloid as adding Karma to the festival. ${ }^{47}$ Roskilde Festival seems like a near perfect match for Hummd's CSR branding. The Orange Feeling and Orange Karma can be seen to

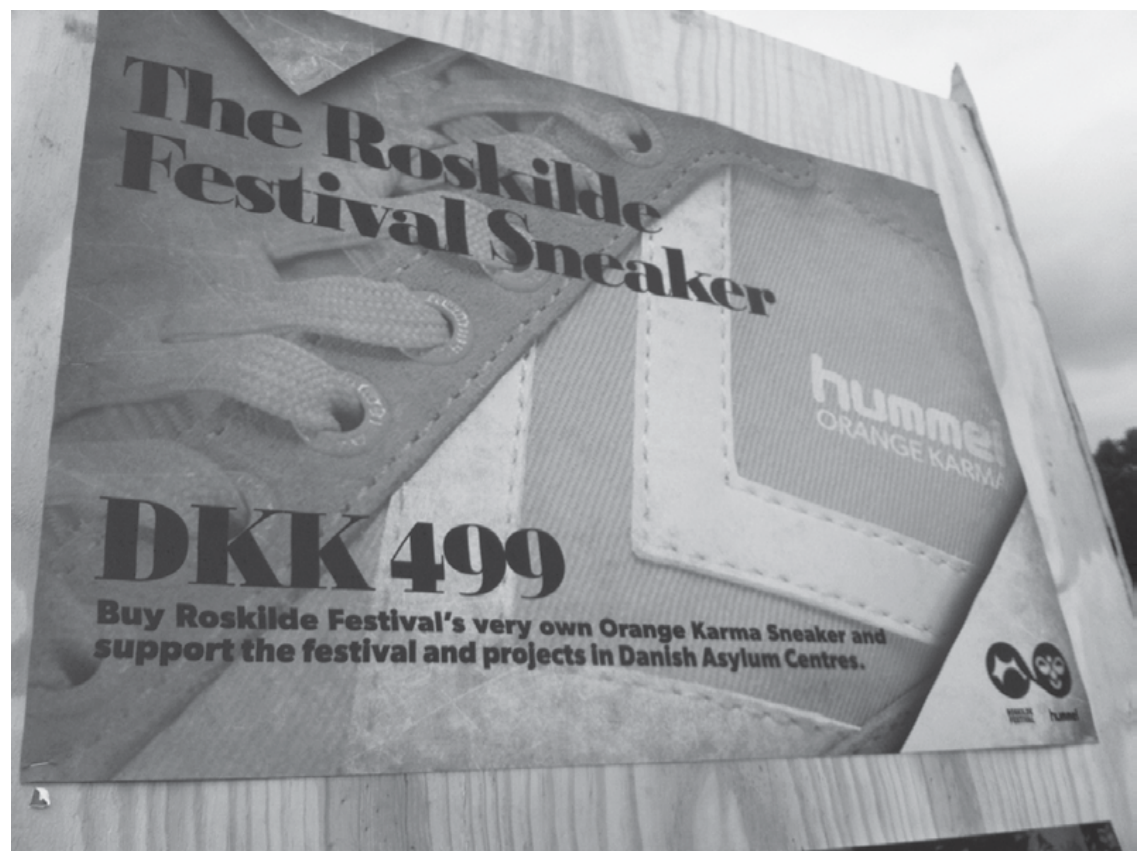

Figure 12.8 Photo of commercial poster advertising Hummd sneakers at Roskilde Festival 
complement, and blend seamlessly into, each other. At another level, however, the fi between Orange Karma and Roskilde Festival seems to benefit ainly Hummd.

The chronotope of the festival is characterised by being limited both geographically (to the festival grounds) and in time (the festival takes place during a short well-defin d period of time). However, as argued above, this time-place is stretched beyond the fixed geographical and temporal boundaries of the festival via online representations of the festival by numerous actors: the festival organisation itself, participants in the festival, volunteer organisations, NGOs and corporate sponsors such as Humme. On the one hand, Orange Karma is as such provided with a timeplace, Roskilde Festival, where it can manifest its physicalpresence, as the bearer of 'good karma', and become associated with the positve vibes of the Orange Feeling. On the other hand, it also acquires a virtual time-space for positioning itself, especially on the Internet, as a commercial corporation benefi ing from what amounts to generous advertising. Furthermore, the corporation's association with the Roskilde Festival places Orange Karma as a co-imaginer of new possible meanings and noms for society. In this way it can promote the Hummd brand as symbolising the 'community, solidarity and free spiritedness' associated with these new norms. Th s arguably adds signific nt value to a fashion spots brand.

Whether or not theinclusionofa corporate brand suchasHummd intheprocesses of creating new cultural meanings enables the imagining of new equalities is a critical question. The carnivalesque spirit of turning normal hierarchies of authority upside down, of mocking the clergy and of using laughter and bodily functions as mediums for this mockery, appear far removed from the Company Karma imagery associated with Christian Stadil's Buddhist fashioniconography and the Hummd brand. Likewise, it seems strange that the seriousness of the online representations of the young asylum-seekers and the young children struggling with mental illness fl w seamlessly into the carefree spirit of the festival. Th s apparent contradiction, nevertheless, does correspond well with the festival's overall humanitarian manifesto and carnivalesque spirit. Solemnity and laughter are both part of the festival chronotope and the connection between the two may be integral to the creation of utopian imaginings of new and diff rent cultural imaginaries. Th se imaginaries, however, are also part of a corporate branding strategy that may be regarded as a means of exploiting the festival chronotope for ends that have more to do with private gain than community building, and which are thus counter to the carnivalesque spirit.

\section{Notes}

1 For example, A. Biccum, 'Marketing Development: Celebrity Politics and the "New" Development Advocacy', Third World Quarterly, 32:7 (2011), pp. 1331-46; L. Chouliaraki, 'The Th atricality of Humanitarianism A Critique of Celebrity Advocacy', Communication and Critical/Cultural Studies, 9:1(2012), pp. 1-21;A. de Waal, 'TheHumanitarian Carnival: A Celebrity Vogue, World Affairs, D1:2 (D08), pp. 43-55. 
2 Forexample,L.A. RicheyandS. Ponte, Brand Aid: Shopping Well to Save the World (Minneapolis and London: University of Minnesota Press, 2011); I. Kapoor, Celebrity Humanitarianism: The Ideology of Global Charity (New York: Routledge, 2013).

3 For example, L. Chouliaraki, The Ironic Spectator: Solidarity in the Age of Post-Humanitarianism (Cambridge: Polity Press, 2013); Kapoor, Celebrity Humanitarianism; M. K. Goodman and C. Barnes, 'Star/ Poverty Space: The Making of the "Development Celebrity"', Celebrity Studies 2:1 (2011), pp 69-85.

4 See M. Horkheimer and T. W. Adomo, Dialectic of Enlightenment: Philosophical Fragments, trans. E. Jephcott, ed. G. S. Noerr (Stanford: Stanford University Press, 2002).

5 R. Silverstone, Media and Morality: On the Rise of the Mediapolis (Cambridge: Polity Press, 2007), p. 125

6 For example, M. F. Olwig and L. B. Christiansen, 'Irony and Politically Incorrect Humanitarianism: Danish Celebrity-Led Benefit Events', in L. A. Richey (ed.), Celebrity Humanitarianism and North-South Relations: Politics, Place and Power (Londonand New York: Routledge, 2015), pp. 170-88; Biccum, 'Marketing Development'; J. Street, 'Celebrity Politicians: Popular Culture and Political Representation', British Journal of Politics and International Relations, 6:4 (2004), pp. 435-52; D. Lewis, D. Rodgers and M. Woolcock (eds), Popular Representations of Develoopment: Insights from Novels, Films, Television and Social Media (London: Routledge, 2014).

7 M. Bakhtin, Rabelais and His World, trans. H. Iswolsky (Bloomington and Indianapolis: Indiana University Press, 1984).

8 M. Bakhtin, Problems of Dostoevsky's Poetics, ed. and trans. C. Emerson, int. W. C. Booth (Minneapolis and London: University of Minnesota Press, 1984).

9 S. Hildebrandt and C. Stadil, Company Karma (Copenhagen: Lindhardt og Ringhof, 2007).

10 S. Gyimóthy and M. Trandberg Jensen, 'Re-Enchanting the "Orange Feeling" in the Festival Community', in B. TimmKnudsen, D. RefslundChristensen and P. Blenker (eds), Enterprising Initiatives in the Experience Economy: Transforming Social Worlds (New York: Routledge, 2015), pp. 209-25.

11 Lene Bull Christiansen, fi ld notes, 30 June 2015.

12 See M. F. Olwig and L. B. Christiansen, 'Festive Environmentalism: A Carnevalesque Reading of Eco-Voluntourism at the Roskilde Festival', in M. Mostafanezhad, R. Norum, E. J. Shelton and A. Thomp on-Carr (eds), Political Ecology of Tourism. Community, Power and the Environment (New York: Routledge, 2016), pp. 108-28.

13 Hildebrandt and Stadil, Company Karma.

14 See his website (www.christianstadil.com. Accessed 6 March 2016), his Facebook page (www. facebook.com/pages/ Christian-Stadil/ 1413894892175762?fref=ts. Accessed 6 March 2016) and his Instagram account (www.instagram.com/p/5C44oBGHZl/?taken-by=christian_stadil. Accessed 6 March 2016).

15 M. Bell and M. E. Gardiner (eds), Bakhtin and the Human Sciences (London, Thou and Oaks and New Delhi: Sage, 1998), p. 5.

16 Olwig and Christiansen, 'Festival Environmentalism', p. 12.

17 Bakhtin, Problems of Dostoevsky's Poetics, p. 126.

18 M. Bakhtin, Karneval og latterkultur, trans. J. Hansen (Copenhagen: Det Lille Forlag, 2001),p. 45.

19 For example, M. Valverde, 'Studying the Governance of Crime and Security: Space, Time and Jurisdiction', Criminology and Criminal Justice, 14:4 (2014), pp 379-91.

20 Bakhtin, Problems of Dostoevsky's Poetics, p. 106. Bakhtin uses the concept 'world sense' rather than 'world view'.

21 M. Holquist, Dialogism: Bakhtin and His World (London: Routledge, 2ndedn, 2002), pp. 88-9. 
22 Bakhtin, Problems of Dostoevsky's Poetics, p. 107.

23 Y. Tuan, Space and Place: Humanist Perspective', Progress in Geography, 6 (1974), pp. 211-52.

24 Tuan, Space and Place', p. 213.

25 Tuan, Space and Place', p. 213.

26 See https:// eirsoccer.com. According to Norse mythology, a Valkyrie decides who lives and dies in battl . Accessed 15 March 2017.

27 See https:// eirsoccer.com. Accessed 15 March 2017.

28 See https:// eirsoccer.com. Accessed 15 March 2017.

29 See https://eir soccer.com. Accessed 15 March 2017.

30 Hummd, 'Girl Power and Fisherman,' (7 January 2013), http://w ww.hummd.net/aa-DK/ karma/page/373/GirlPowerandFisherman. Accessed 16 March 2015.

31 Mette Fog Olwig, fi ld notes, 12 July 2013.

32 Snobrød ('Twistbread') is bread on a stick that is made over a bonfie and usually with children.

33 Mette Fog Olwig, fi ld notes, 2 July 2013.

34 See http://g amedenmark.org/om-game/. Accessed 20 February 2016. Game Denmark, 'Støtte på Asfalten' (15 January 2016), www.youtubecom/watch?v=jImL8xhmv6w. Accessed 15 March 2017.

35 A. Rønning-Andersson, 'Filantropisk Iværksætter Med Forretningsmæssig Forståelse', Henley Business School Danmark (3 October 2016), http:// henleydk/ henley-magasinet/ filantropiskivaerksaetter-forretningsmaessig-forstaaelse/ . Accessed 15 March 2017.

36 S. Prahm, GAME Årberetning 2015 (Copenhagen: GAME Denmark, 2015), translated from the Danish by the athors.

37 Tho nico, 'Spreading Orange Karma at Roskilde Festival 2015', Thornico (9 July 2015), www.thornico.com/Sport--Fashion4701/Spreading-Orange-Karma-at-Roskilde-Festival2015.900033.aspx. Accessed 15 March 2017.

38 Lene Bull Christiansen, fi ld notes, 30 June 2015.

39 hummd 1923TV, 'hummd girls at Sensational Football at Roskilde Festival' (16 July2012), www. youtubecom/watch? $=$ =-XwKasw4SN4. Accessed 15March 2017; hummd1923TV, 'Sensational Football at Roskilde Festival 2013' (12 July 2013), www.youtubecom/watch?v=BvlnBOprvfs. Accessed 15 March 2017; S SS, 'Sensational På Roskilde Festival' (7 July 2010), www.youtube. $\mathrm{com} /$ watch? $\mathrm{v}=$ tgo3dUh3QZU. Accessed $15 \mathrm{March} 2017$.

40 For example, hummd1923TV, 'Orange Karma Asylum - Featuring Midheta \& Mihreta' (2 July 2013), www.youtubecom/watch?v=DaQoopQkVAQ. Accessed 15 March 2017; hummd 1923TV, 'Orange Karma Asylum - Featuring Mildred' (2 July 2013), www.youtube. com/watch? $v=x Q 1 X L B N B n \_g$. Accessed 15 March 2017.

41 hummd 1923TV, 'Orange Karma Asylum - Featuring Midheta \& Mihreta', translated from the Danish by the authors.

42 hummd1923TV, 'Orange Karma Asylum - Featuring Nancy' (2 July 2013), www.youtube $\mathrm{com} /$ watch? $\mathrm{v}=$ GheBhTdQO0g. Accessed 15 March 2017.

43 Game Denmark, 'Støtte på Asfalten', translated from the Danish by the authors.

44 For example hummd 1923TV, 'Sensational Football at Roskilde Festival 2013'; Game Denmark, 'GAME at Roskilde Festival 2015' (6 July 2015), www.youtubecom/watch?v=bbXJ2F6R-ds. Accessed 15March 2017; Orange Karma, 'Orange Karma Sensational 2013 - TheFinals' (5 July 2013), www.youtubecom/watch?v=R3DzFzW2FcQ. Accessed 15 March 2017.

45 hummd 1923TV, 'Orange Karma Asylum - Featuring Midheta \& Mihreta'.

46 Hildebrandt and Stadil, Company Karma.

47 See Christian Stadil's Instagram (2016), www.instagram.com/p/5C44oBGHZl/?takenby=christian_stadil. Accessed 15 March 2017. 


\section{References}

Bakhtin, M., Problems of Dostoevsky's Poetics, ed. and trans. C. Emerson, int. W. C. Booth (Minneapolis and London: University of Minnesota Press, 1984).

Bakhtin, M., Rabelais and His World, trans. H. Iswolsky (Bloomington and Indianapolis: Indiana University Press, 1984).

Bakhtin, M, Karneval og latterkultur, trans. J. Hansen (Copenhagen: Det Lille Forlag, 2001).

Bell, M. and M. E. Gardiner (eds), Bakhtin and the Human Sciences (London, Thou and Oaks and New Delhi: Sage, 1998).

Biccum, A. 'Marketing Development: Celebrity Politics and the "New" Development Advocacy', Third World Quarterly, 32:7 (2011), pp 1331-46.

Chouliaraki, L. 'The Th atricality of Humanitarianism A Critique of Celebrity Advocacy', Communication and Critical/Cultural Studies, 9:1 (D)12), pp. 1-21.

Chouliaraki, L., The Ironic Spectator: Solidarity in the Age of Post-Humanitarianism (Cambridge: Polity Press, 2013).

Game Denmark, 'GAME at Roskilde Festival 2015' (6 July 2015), www.youtubecom/watch?v= bbXJ2F6R-ds. Accessed 15 March 2017.

GameDenmark, 'Støtte på Asfalten' (15January 2016), www.youtubecom/watch?v=jImL8xhmv6w. Accessed 15 March 2017.

Goodman, M. K. and C. Barnes, 'Star/Poverty Space: The Making of the "Development Celebrity"', Celebrity Studies, 2:1 (D11), pp 69-85.

Gyimóthy, S. and M. Trandberg Jensen, 'Re-Enchanting the "Orange Feeling" in the Festival Community', in B. TimmKnudsen,D. RefslundChristensen andP. Blenker(eds), Enterprising Initiatives in the Experience Economy: Transforming Social Worlds (New York: Routledge, 2015), pp 209-25.

Hildebrandt, S. and C. Stadil, Company Karma (Copenhagen: Lindhardt og Ringhof, 2007).

Holquist, M., Dialogism: Bakhtin and His World (London: Routledge, 2nd edn, 2002).

Horkheimer, M. and T. W. Adomo, Dialectic of Enlightenment: Philosophical Fragments, trans. E. Jephcott, ed. G. S. Noerr (Stanford: Stanford University Press, 2002).

humme 1923TV, 'humme girls at Sensational Football at Roskilde Festival' (16 July 2012), www. youtubecom/watch?v=-XwKasw4SN4. Accessed 15 March 2017.

humme1923TV, 'Orange Karma Asylum - Featuring Midheta \& Mihreta' (2 July 2013), www. youtubecom/watch?v=DaQoopQkVAQ. Accessed 15 March 2017.

hummd 1923TV, 'Orange Karma Asylum - Featuring Mildred' (2 July 2013), www.youtubecom/ watch? $=$ xQlXLBNBn_g. Accessed 15 March 2017.

hummd1923TV, 'Orange Karma Asylum - Featuring Nancy' (2 July 2013), www.youtubecom/ watch? $\mathrm{v}=$ GheBhTdQO0g. Accessed 15 March 2017.

hummd 1923TV, 'Sensational Football at Roskilde Festival 2013 ' (12 July 2013), www.youtubecom/ watch?v=BvlnBOprvfs. Accessed 15 March 2017.

Kapoor, I., Celebrity Humanitarianism: The Ideology of Global Charity (New York: Routledge, 2013).

Lewis, D., D. Rodgers and M. Woolcock (eds), Popular Representations of Development: Insights from Novels, Films, Television and Social Media (London: Routledge, 2014).

Olwig, M. F. and L. B. Christiansen, 'Irony and Politically Incorrect Humanitarianism: Danish Celebrity-Led Benefit Events', in L. A. Richey (ed.), Celebrity Humanitarianism and NorthSouth Relations: Politics, Place and Power (London and New York: Routledge, 2015), pp. $170-88$.

Olwig, M. F. and L. B. Christiansen, 'Festive Environmentalism: A Carnevalesque Reading of EcoVoluntourism at the Roskilde Festival', in M. Mostafanezhad, R. Norum, E. J. Shelton and 
A. Thomp on-Carr (eds), Political Ecology of Tourism: Community, Power and the Environment (New York: Routledge, 2016), pp. 108-28.

Orange Karma, 'Orange Karma Sensational $201_{3}$ - The Finals' (5 July 2013), www.youtubecom/ watch?v=R3DzFzW2EcQ. Accessed 15 March 2017.

Prahm, S, GAME Årsberetning 2015 (Copenhagen: GAME Denmark, 2015).

Richey, L. A. and S. Ponte, Brand Aid: Shopping Well to Save the World (Minneapolis and London: University of Minnesota Press, 2011).

Rønning-Andersson, A., 'Filantropisk Iværksætter Med Forretningsmæssig Forståelse', Henley Business School Danmark (3 October 2016), http:// henley.dk/ henley-magasinet/ filantropiskivaerksaetter-forretningsmaessig-forstaaelse/. Accessed 15 March 2017.

S SS, 'Sensational På Roskilde Festival' (7 July2010), www.youtubecom/watch?v=tgo3dUh3QZU. Accessed 15 March 2017.

Silverstone, R., Media and Morality: On the Rise of the Mediapolis (Cambridge: Polity Press, 2007).

Street, J., 'Celebrity Politicians: Popular Culture and Political Representation', British Journal of Politics and International Relations, 6:4 (2004), pp. 435-52.

Tho nico, 'Spreading Orange Karma at Roskilde Festival 2015, Thornico (9 July 2015), www. thornico.com/Sport--Fashion4701/Spreading-Orange-Karma-at-Roskilde-Festival2015.900033.aspx. Accessed 15 March 2017.

Tuan, Y, 'Space and Place: Humanist Perspective', Progress in Geography, 6 (1974), pp. 211-52.

Valverde, M., 'Studying the Governance of Crime and Security: Space, Time and Jurisdiction, Criminology and Criminal Justice, 14:4 (2014), pp 379-91.

de Waal, A., 'TheHumanitarian Carnival: A Celebrity Vogue', World Affairs, 171:2(2008), pp. 43-55. 


\section{Index}

activism 228

humanitarian 217

online 209, 226, 230

see also clicktivism

advertising 46, 59, 61, 74, 96, 194, 224, 228

campaigns $128,131,135,155,237$,

$$
\text { 253-6, } 262
$$

advocacy 132, 136, 193, 196-7

Agamben, Giorgio 23, 109, 147

see also 'bare life'

agency $52,87,107,115,152,190,211,237$

agency (noun) 18, 39, 61, 63, 70, 131, 136, $148-9,168,172,175-6,213$

aid 2, 5, 6, 8, 18, 39-43, 47, 52, 59, 60, 62, $73,74,83$

agencies $6,89,129,132,134-5$, 167-86

and journalists 167-86

joumalists 168

operations 168

workers $6,88,98,126,167,169,171$, 176,180

Al-Arabiya (TV station) 176

Amazing Mrs Holliday, The (Renoir/Danning, 1942) $15,19,20,24-7,32$

American Red Cross 2

Amnesty International 111, 160n27

appeal 18, 106, 115, 127, 128-36, 235

Arab Spring 209

archive 7, 41, 44, 45, 71, 73, 112, 233, 238

Arendt, Hannah 112

asylum-seekers 146, 154, 157, 248, 250, 252, $255,258,260-3$ audiences $1,4,8,18,20-5,27,29,30,32$, $40-2,59,60,68-70,73-5,85,88,92$, $105,107,112,122,125,126-8,155$, $171,180,187,188,190,191-8,225$, $227,231-2,235-8,247,253$

Australia 127, 161n55

Austria 41, 43, 52

authenticity 5, 17, 21, 22, 24, 30, 32, 83, 97, 228,232

awareness 1, 3, 4, 83, 131, 133, 136, 153, 168, $171,172,178-80,194-6,214,233,234$

Bakhtin, Mikhail 238, 246, 249, 250, 251

see also carnival/esque; chronotope

Band Aid 123, 135

Banker to the Poor (Muhammad Yunus) $86,92-7$

'bare life' 23, 109, 147, 157

Bauman, Zygmunt 210

Bazin, André 21

BBC 107, 108, 109-10, 123, 128, $137 n 3,174-5$

Belafonte, Harry 61

Belgium 19, 127

Bentham, Jeremy 229

Berger, John 108

biopolitics 147

Bonney, Th rese 23

Border Street (Ford, 1948) 20

borders 7, 20, 146, 151, 152, 167, 196

control of 5, 146, 147, 148, 151, 156

domestic 218

European 145, 148, 149, 156, 157 
international 47

militarisation of 146,156

sea 109,114

Bourdieu, Pierre 210

Boy with Green Hair, The (Losey, 1948) 15, 19, 20, 29-32, 30, 31

branding 3, 7, 221, 225, 226, 233, 246, 247 corporate $147,227,228,246,248,251$, $252,262,263$

cosmopolitan 208

emotional 208

British Documentary Film Movement 43, 44, 47

British Red Cross 128, 131

British Government 123, 132, 133, 236

broadcaster 5, 105, 123, 124, 128, 129, $137 \mathrm{n} 3$

Butler, Judith 16, 18

Buzzfeed 173, 178

CAFOD see Catholic Fund for Orerseas Development

campaigners $113,232,237,238$

campaigns $4,7,19,155,156,227-8,233,234$, 236,249

advocacy 136

awareness 179

humanitarian $32,188,225,226$, 232,238

media 5, 6, 39, 148, 194

protest 235

Capra, Frank 35, 40, 41

care $3,5,6,15,17,18,20,22,23,30,45,126$, $145,147,148,150,151,156,207$, $208,212,217,226$

CARE see Cooperative for Assistance and Relief Everywhere

carnival/esque 238, 246-7, 249-50, 251, 252,263

Catholic Fund for Qrerseas Development (CAFOD) 128, 131

CBS 61, 109

celebrity 6, 61, 62, 88, 136, 153, 167, 169, 211, $237,238,246,248,256,258,260$

censorship 106

charity $6,19,29,84,135,136,167,174,187$, 192-4, 196, 233, 236, 247

events 187 see also Catholic Fund for Orerseas

Development; Christian Aid;

Cooperative for Assistance and

Relief Everywhere; Oxfam; Red

Cross; United Nations International

Children's Emergency Fund

childhood 4, 6, 115, 168, 169, 172, 173, 180, 209-12, 213-23

see also children

children 4, 6-8, 15-38, 49-53, 69, 71, 86, 103, $105,107,125,126,130,151,152$, 153, 167-86, 187, 207, 210-21, 224, $237,238,256,260,263$

'African' 237

distant 6, 18, 122, 207, 217, 218

Ethiopian 135

foreign $6,17,18$

iconography of 106, 236

images of 47, 129, 131, 136

international 18, 25, 47

Palestinian 105, 106, 116n8

representation of $15,18,32,224$

Syrian $170-3,179,180$

see also childhood; Save the Children

China Girl (Hathaway, 1942) 24-5

Chouliaraki, Lilie 3, 16, 36n63, 150, 152, 193, 230-1,234, 235

Christian Aid 128, 131, 133, 225

Christian Relief and Development Association (CRDA) (Ethiopia) 124

chronotope 250-1, 257, 260, 261, 263

cinema 5, 40, 42-4, 52, 103-21, 153

American 21

European 20, 21

Hollywood 4, 15-38, 61, 62, 68, 110,151

popuar 4,16

citizen 218

ethical208, 209, 214, 217, 219n1

global 209

political6, 207, 208, 215, 216, 218

sustainable 211,212

citizenship 17, 157, 191, 238, 260

global 212

national 215

clicktivism 226

see also activism, online

CNN 104, 173, 175 
Cold War 2, 42, 46, 50, 53, 59-60, 61, 62, 66, $72,83-4,124,200$ n33

collective risk 188,197

colonialism 5, 110, 116, 124, 130, 132, 133, 159 n 12,216

Comic Relief 235

common snse humanitarianism (Tester) 231

communications $1,3,46,61,71,110$, $130,132,133,135,136,178,225$, $228-38,251$

community $2,16,17,71,72,87,108,113$, $116,129,174,178,179,188,196$, $247,248,251,256,258-60,262-3$

aid $123,131,136$

'imagined community' 151

moral 212

compassion 15, 21, 83, 111, 112, 113, 129, 147, 149-51, 157, 195

compassion fatigue (Moeller) 193, 234 compassionate repression (Fassin) 157 complicity $96,106,112,149,172$

conflict 103-21

consumer action 209

consumer citizen 218

consumerism 62, 106, 171, 207-23, 227, 228, 230, 261

ethical208, 209, 214, 217,219n1

global 209

political 6, 207, 208, 215,216, 218

sustainable 211, 212

Cooperative for Assistance and Relief Everywhere (CARE) 97n4, 97n5

corporate agenda 227,228

corporate sponsor 247, 262, 263

cosmopolitanism (Kant) 154

CRDA see Christian Relief and Development Association

crisis $1,2,5,6,7,62,83,106,108,123,124$, $128,132-4,157,167,169,178,180$, 190, 192-5, 197, 198, 209, 249

crisis management 147

migration crisis $145,147,148,152$, 153,154

refugee crisis $167,177,179,180,196,216$

Syrian 171, 172, 173, 177, 179, 180

culture $1-4,7,8,32,39,44,60-4,74,83,84$, $87,88,89,91,96,97,123,150,187$,
$196,207,217,231,232,238,246$, $247,251,260$

national 43

popular $4,17,59,60,68-70,73,74,246$

cuteness 17, 21, 24, 28, 29, 32

Daily Telegraph 175, 197

Danish Red Cross 252

De Certeau, Michel 230

De Sica, Vittorio 20, 21

death $25,45,46,52,104,105,106,111,124$, $125,131,145,147,150,153,154$, $156,157,195,249$

Debord, Guy 187

DEC see Disasters Emergency Committee democracy 41, 46, 60, 108, 124, 146, 147, 154,191

Denmark 127, 148, 155, 247, 256, 257, 258

Department for International Development (DfID) 132

detachment 187, 191, 193, 195, 260

development 88, 91, 92, 95, 96, 124, 128, 131, $132,133,135,136,210,213$

developing nations $65,66,70,73,89,94$, 134, 193

see also international development

DfID see Department for International Development

Diary for Timothy, A (Jennings) 51

Dimbleby, Jonathan 122-3, 124-5, 128, 134 see also Unknown Famine, The

Disaster Unit (within ODM 134

disasters 1, 5, 7, 104, 107, 122, 123, 124, 125, $127-38,169,171,193,195,237$

Disasters Emergency Committee (DEC) 106, $128-35$

discourse $5,6,7,17,25,40,41,43,44,47,49$, $50,52,65,73,84,85,108,130,132$, 136, 145-51, 155, 156, 158n1, 169$74,179,180,195,215,216,225,232$, 233, 234, 246

see also human rights; media; security distant other/s 1, 3, 16, 30, 208, 215, 231 documentary 4, 5, 8, 31, 32, 40, 43-8, 113, $122-5,127-9,132,156,173$ see also British Documentary Movement Dunant, Henri 83, 87, 99n24

Durbin, Deanna 19, 24 
Eastwood, Clint 61

education $6,83,86,88,90,91,123,132,135$, $136,168,172-4,179,180,226,235$, 236,237

emergency 2, 5, 8, 48, 84, 86, 87, 91, 128-40, $145,146,150,151,157,168,176,179$ see also Disasters Emergency Committee; United Nations International Children's Emergency Fund

emotions 176, 187, 196, 207, 209 moral 215, 218

empathy $112,122,133,176,187,190,191$, $195,196,208,227$

empowerment 51,83

engagement $3,92,103,111,131,136,193$, $225,229,232,233,247$

political 190, 226

public 59, 135, 187, 191, 231, 235, 237,238

Enlightenment, The44, 52, 154, 196, 198

Enough Food IF (UK) 153, 225, 227, 228, $229,230-1,233,235,236,237-8$

entertainment $17,21,24,25,32,61,68,74$, 187,210

environment 3, 73, 92, 135, 136, 168, 170, 188, 197, 207, 213, 216, 226, 229, $231,232,236,247,248,259$

Eritrea 154

ERP see European Recovery Programme ethics $2,3,8,16,89,168,178,180,190,192$, $198,211,215,217,218$

see also consumerism, ethical

Ethiopia 123, 124, 125, 128, 129, 130, 131, 132,133

Ethiopian Government 125, 126, 129

Ethiopian Famine (1973-5) 122, 124, 131, 132,135

see also Unknown Famine, The

Ethiopian Famine (1984-5) 123, 135

Ethiopian Government 125, 126, 129

Europe's Children (Bonney, 1943) 23

European Commission98n10, 148

European Film Unit 40, 46

European Recovery Programme (ERP) $39,41,47$

see also Marshall Plan

European Union 145, 146-7, 148, 149, 154, $155,156,157-8,160$ n28
Europol 148

everyday life $93,113,125,158,226,230,232$, 259,260

extremism 88, 146

Facebook 2, 153, 209, 224-45, 247, 249

family $15,17,25,27,46,110,115,125,175$, 177,208

famine $5,7,93,122-42,193,208$

see also Ethiopian famine (1973-5);

Ethiopian famine (1984-5); Unknown Famine, The

fantasy 4, 15, 30, 31, 32, 95, 96

Fassin, Dider 10n10, 85, 107, 157

fear 22, 25, 41, 62, 109, 110, 114, 125, 145, $153,155,156,175,178,156,161$, $188,192,195,196,213,214,219$

of the other 171,180

feminism 62

Ferno, John 31, 43

festival 1, 2, 6, 7, 41, 46, 113, 156, 246-67

film $16,18,45,56,113,156$

Fire at Sea (Rosi, 2016) 156

First WorldWar 2

Folman, Ari 103, 112

see also Waltz with Bashir

Fondazione Rava 150

Ford, Aleksander 20

foreigner 157, 172

Foucault, Michel 147, 229

Four Hundred Million, The (Joris Ivens and John Ferno, 1939) 31

Fox News 197

frameworks 44, 45, 56, 84, 112, 131, 134, 190, $191,193,238$

Frissell, Toni 7-8

Frontex 147, 148-9, 150, 156

GAME (Denmark) 248, 256, 257, 259, 260,261

games $59,74,171,225,232,237,246,248$, $249,253,254,259,260$

online 7, 246

Gandhi, Mahatma 248

gaze 21, 25, 27, 115

colonial 224

gender 60, 64, 177, 208, 216, 230, 252

Geneva Convention 83 
geopolitics 40, 41, 42, 44, 45, 52, 146,

$$
\text { 152, } 156
$$

Germany, Year Zero (Rossellini, 1948) 20, 21

Giddens, Anthony 192

global warming 197

Good Life, The (Humphrey Jennings and Graham Wallace) 43, 44-5, 46-53

government $5,7,18,41,46,50,60,72,73$, $105,106,112,123,124,134,158$,

$176,178,193,197,214,225,234$

see also British Government

Grameen Bank91-2, 95, 96, 97, 100n30

Gramsci, Antonio 231

Greece 19, 39-58, 145, 157

Greek Civil War (1945-9) 41-2, 43, 47, $49,51,52$

Greek War Relief Association 29

Grierson, John 46

Guardian, The 178

guilt $67,112,130$

Hamas 104, 105, 106, 107, 108, 109, 110, 111, $112,114,117 \mathrm{n} 27$

Haslemere Declaration, The (1968) 131

Heavenly Days (Estabrook, 1944) 15, 19, 20, 27-9, 32

Hobbes, Tho as 237

Hollywood 61, 62, 68, 151

cinema 15-38, 110

see also cinema, Hollywood

Honourable Woman, The (BBC) 110

hospitality 7, 22, 23, 155

House of Commons 123, 127, 133

see also government, British

human rights 160n28, 209

discourse 156

humanitarian campaigns 4, 29, 30, 32, 188,226

humanitarian events 247, 249, 251, 253

humanitarian movements 16

humanitarianism 1-10, 15, 18, 39, 41, 42, 47, $84,86,88,89,96,107,122-42,149$, 178, 207, 209, 217, 224, 229, 231, $234,246,261,263$

and action 3, 6, 18, 31, 146, 149, 209, 234,236

and activism 217

and assistance 131, 134, 149, 157, 172, 194
British 5, 122, 123, 135

crisis in 1, 2, 5, 146, 167, 190, 194, 197, 198

and duty 156

and emergency 2, 8, 145

global 1, 4, 6, 15, 39, 96, 97, 129, 135, 168, 207, 209, 217, 218, 219

and marratives 4, 6, 39-58, 83, 86, 97, 148, 151, 156, 157, 191

and news 191, 194

and NGO campaigns 225

politics 230

and rhđoric 157

and risk 194, 195, 197

and self-perception 156

and sentiment 4, 15, 16, 21, 23

humour224, 226, 235, 237, 238

see also carnival/esque; Comic Relief; satire Hungary 20, 72, 148, 155

ICRC see International Committee of the Red Cross

ideology 42, 50, 52, 96, 226, 238

IHL see International Humanitarian Law imaginary 3, 32, 95, 103, 148, 150, 151, 152,153

immigrants 145, 154

impartiality 168

inequality $91,95,136,153,197,217,250$

injustice 7, 83, 112, 114, 189, 238

innocence 21, 96, 209, 211, 215

Instagram 153, 228, 247, 249, 261

International Committee of the Red Cross (ICRC) 2, 83

international development $59,60,61,62,64$, $70,74,75,86,87,88,91,92,96,132$

International Humanitarian Law

(IHL) $110-12$

International Organization for Mgration (IOM) 153, 155

International Red Cross 135

international relations $17,23,41,68$

internationalism 4, 16, 17, 18, 24, 47, 52

IOM see International Organization for Migration

Iraq 170

Ireland 41, 127, 128

Israel $72,103-21$

Italian Neorealism 20 
Italian Red Cross 150

Italy 41

ITV 122, 123, 127, 128, 129, 134, 137n3

Ivens, Joris 31

Izzard, Eddie 153

Jennings, Humphrey 43, 44-7, 50, 51, 52 see also Good Life, The

Jolie, Angelina 170

Jordan 6, 19, 155, 167-86

journalism 1, 6, 188-204

joumalists 169, 175

justice $6,7,83,108,112,113,114,116,135$, $188,189,190,192,196,207,219,238$

Kant, Immanuel 154, 191-2

Kennedy, John F. (President) 59, 60, 61, 62, $63,64,66,68,71$

Kerry, John 55n31, 170

Ki-moon,Ban 155

Kosovo 200n33

Kurdi, Alan 158, 216-17

Lamprecht, Gerhard 20

Laqueur, Tho as 47

Lebanon 155, 170, 256

Lebanon War (1982) 103

Libya $145,147,154,200$ n33

life-writing 5, 83, 85, 96

Live Aid 123, 172, 187

Make Poverty History 153, 235, 236

Mare Nostrum 149, 150, 151, 152

Marshall, George, General 39, 40

Marshall Plan (MP) 39-41

Marshall Plan Films 39-58

Mbembe, Achile 147

McDowall, Roddy 19, 21, 22

Mead, Margaret 61

media

campaigns 5, 39, 40, 41, 148, 152, 156, 194

consumers 106

coverage $6,65,70,74,107,123,146,167$, $168,170,173,175,177,179,193$

events 187

producers 171

Mediterranean Sea 146, 151, 153, 156

Memory of Solferino, A (Dunant) 83
Middle East 64, 146, 169

military $7,40,41,42,48,67,72,84,87,88$, $104,111,114,115,145,146,148$, $150,151,152,153$

see also borders; humanitarianism

Ministry for Orerseas Development (ODM) 134

Missionaries 124, 130, 234

Moeller, Susan 107, 193

see also compassion fatigue (Moeller)

moral panic 196, 197

Mortenson, Greg 86, 96-7

see also Three Cups of Tea

Mother Teresa 89

Mussolini 151

MySpace 228

\section{NASA 84}

nationalism 4, 16, 17, 18, 24, 47, 52, 208, 214

necropolitics 147

neo-humanitarianism 42, 52

neoliberalism 212

Netanyahu, Binyamin 104, 105, 106, 111

neutrality 48, 190, 191, 193

news 5, 46, 61, 107, 108, 109, 115, 129, 135, 136, 151, 152, 154, 167, 168, 170, 173,

$175,177,178,179,188,190,191,194$

coverage 103, 111, 112, 113, 114, 187, 195

media 103, 105, 110, 193, 197

newspapers 2, 22, 39, 59, 69, 155, 169, 229

newsreels 40, 43

reports $128,130,133,180$

NGOs see Non-Governmental Organisations

Nigeria 70, 154

Nigerian Civil War (1968) 128, 130-1, 132

No Lost Generation (initiative) 172-3, 180

Non-Governmental Organisations (NGOs) 5, $6,84,92,110,122,123,124,127-9$, $130,131-2,134,135,136,149,153$, $193,217,224-38$

see also Catholic Fund for Orerseas Development; Christian Aid;

Cooperative for Assistance and Relief Everywhere; Oxfam; Red Cross

O’Brien, Margaret 21, 24

ODA see Overseas Development Adminstration 
ODM see Ministry for Overseas Development

Overseas Development Adminstration (ODA) 132-3, 134

Oxfam 46, 52, 124, 127, 128, 130, 131, 132, 136,225

parenting 207-23

participation 27, 83, 150, 208, 226, 232, 233, $238,256,261$

patriotism 4

Patty Duke Show, The 69-70

peace $16,17,18,30,32,39,42,59,85,88,91$, 109,260

see also United States Peace Corps

perception management 103-21

personality 5, 89, 91, 97, 193

Phan Thi Kim huc 105

philanthropy 130, 246

photography $7,23,32,40,47,63,64,65,103$, $105,124,127,151,174,176,178$, $216,230,252$

Pichel, Irving 15

see also Pied Piper, The

Pied Piper, The (Pichel, 1942) 15, 18-19, 22-4, 25, 27, 28, 32

pity $103,113,131,151,187,188,190,193$, 195,196

policy 5, 39, 42, 44, 52, 59, 60, 72, 74, 75, 122 , $123,132,133,134,145,147,149$, 154,188

politics $1,2,5,43,44,52,53,60,62,68,72$, 108, 129, 130, 136, 147, 148, 150, $157,207,209,210,215,217,226$, $230,231,232$

Pope Francis 151

poverty $39,63,75,86,91,92,93,95,108,124$, $130,131,133,136,153,172,178$, $188,197,224-45$

power $46,47,50,51,52,72,83,85,86,88,90$, $91,92,94,96,97,104,105,107,109$, $111,115,116,123,124,125,128$, 130, 147, 152, 188, 196, 207, 210, $212,216,218,225,229,237,246$

power relations $7,16,40,187,229,250$, 251,252

prejudice 153, 224 propaganda 32 , 35n41, 40, 41, 45, 46, 48, 61, $145,150,151,196$

public relations 4, 59-79, 84, 104, 107, 193, 247

publicity 4 , 32, 39, 41, 46, 59-79, 124, 128, 132,135

Qishta, Fida 112, 113, 114, 115

see also Where Should the Birds Fly

radio $59,61,62,63,68,70,73,109$

Radvanyi, Geza20

Rawls, John 188, 189, 191, 192, 198

Red Crescent Movement 135

Red Cross 7, 47, 48, 49

refugee $19,22,35 n 41,89,108,145,152,153$, $154,155,156,157,158 \mathrm{n} 1,169,178$, $179,196,22 \ln 53,258,261$

camp 6, 112, 167, 171, 172, 173, 174, 175,179

crisis 147, 167, 177, 216

Palestinian 107

Syrian 6, 170, 177, 178, 179, 180, 216,217

see also United Nations Refugee Agency

relief $122,123,124,125,128,129,131,132$, 133,134

Renoir, Jean 15, 24

see also Amazing Mrs Holliday, The

Renzi, Matteo 155-6

Reporters without Borders 170

rescue $25,106,150,151,152,154,193$

narratives 20, 218

responsibility $3,6,22,25,27,59,106,107$, $108,113,147,150,153,154,155$, $156,216,217$

corporate social responsibility (CSR) 246

moral 190

political 196

risk 5, 6, 20, 94, 95, 146, 148, 149, 158, 171, 187-204, 211, 213, 215, 216, 217 , $238,250,251$

'poverty risk' 197

'risk society' 192, 212

Rosi, Gianfranco 156

Roskilde Festival 246-67 
Rossellini, Roberto 20, 21

Rotha, Paul 46

Rwanda 200n33

satire 249

see also carnival/e sque; humour

Save the Children 128, 131, 150, 173, 174, $178,225,231,236$

Schengen 145-6, 148, 157

Search, The (Zinnemann, 1948) 21

Seaton, George 21

Second World War 1, 2, 4, 17, 39, 42, 46, $52,61,84$

security $39,94,109,146,149,150,156$, 157,175

Selassie, Haile 123, 124

sentiment 4, 6, 15-38, 50, 151, 158n1, 175, $208,209,218,228,234,238,246$ cosmopolitan 208

Serbia 155

Shoeshine (De Sica, 1946) 20

Shute, Nevil 22, 35n54

Singer, Peter 208

Smith, Adam 208

Snow, Jon (Channel 4) 103, 105, 106

social media 1, 2, 5, 11, 105, 106, 207, 209, $224,225,228,229,230,231$

see also Facebook; YouTube

social network 147, 224, 225, 226, 228, 229, 230, 231, 233, 234, 236

see also Facebook; YouTube solidarity $2,5,6,22,23,32,95,109,113,147$, 156, 157, 187, 190, 191, 192, 196, 231, 247, 263

Somewhere in Berlin (Lamprecht, 1946) 20

Somewhere in Europe (Radvanyi, 1947) 20

Sontag, Susan 106, 138n36

Spanish Givil War 41

spectacle $16,20,32,148,150,153$

see also Debord, Guy

spectators $20,150,151,187,260$

stereotype 18, 70, 130, 136, 237, 238, 252

strangers 3, 153, 173, 209, 212, 233, 261

distant 209, 212

Sudan 98n14, 154

Lost Boys of Sudan 85

suff ring 193 distant 3, 133, 150, 192, 193, 194, 208

surveillance 146, 147, 149, 229

sympathy $2,17,106,107,110,112,116,151$, $195,196,208$

Syria 6, 167-86, 195, 216

see also refugee

television $1,2,4,5,7,9,59,61,68,69,70,74$, $167,122-42,152,212,224$

Temple, Shirley21, 23, 24

terror 31, 88, 91, 107, 108, 109, 145, 146, 158n4, 171, 180, 193, 195

Tester, Keith1, 231

Three Cups of Tea (Mortenson and Relin, 2006) 86-91

torture $22,111,167$

tradition 2, 3, 17, 43, 48, 51, 63, 88, 93, 95, $96,105,113,154,175,180,189,191$, $192,193,217,228,229,233,234$, $235,236,246,250$

trauma 20, 103, 112, 113, 116, 172, 180

Truman, Harry (President) 39, 41, 42

Turkey $73,145,157,170$

Twibbon 233

Twitter 153, 209, 224, 225, 228, 233, 247

UN see United Nations

United Nations (UN) 167, 178

United Nations Educational, Scientific and Gultural Organization (UNESCO) 46, 52

United Nations Food and Agriculture Organisation (UNFAO) 133

United Nations International Children's Emergency Fund (UNICEF) 18, 29, 33n $1,47,124,177,178$

United Nations Refugee Agency (UNHCR) 176

United Nations Relief and Rehabilitation Adminstration (UNRRA) 16, 18, 34n $22,40,48$

United States Agency for hternational Development (USAID) 60, 84

United States Peace Corps 4, 59-79, 83,85

universalism 48,52

Unknown Famine, The 122-42, 126, 127 
USAID see United States Agency for International Development

utility 189

average 188, 191, 194, 196, 198n9, 199

video blog 103, 106, 115

Vietnam 19, 62, 130

Vietnam war 67, 105, 130

violence $5,6,16,104,105,106,107,109,110$,

$111,112,115,116,147,153,154$,

$170,172,173,177$

Virilio, Paul 104

visibility $3,40,148,224,225,229,230,233$, 234,238

volunteer $4,7,25,59,61,62,63,64,65,66$, $67,68,69,70,71,72,73,74,75,85$, $234,235,263$

vulnerability 5, 6, 18, 114, 146, 151, 176, 188, 192

Waltz with Bashir (Folman, 2008) 103, 112, 113, 114, 116

war

'war on terror' 180 see also Cold War; First World Warr; Greek

Civil War; Lebanon War; Nigerian

Civil War; Second World War;

Spanish Civil War; Vietnam War

War on Want 128, 131-2

Warner, Michael 233

Weizman, Eyal 109, 111, 112, 118n39

Where Should the Birds Fly (Qishta, 2013)

103, 113-16

WHO see World Health Organization

Why We Fight (Capra, 1942-5) 40

Williams, Raymond15-16

witness $74,106,110,116,126,134,151$, 217,237

World Health Oganization (WHO) 47

Wright, Basil 46

xenophobia 153

Yousafzai, Malala 173, 174, 174

YouTube 2, 106, 153, 225, 228, 231, 233, 236, 258, 260

Yunus, Muhammad86, 91

see also Banker to the Poor 